\title{
PENGEMBANGAN KAPAS RAKYAT' DI SULAWESI SELATAN
}

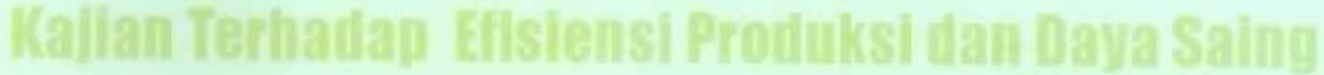

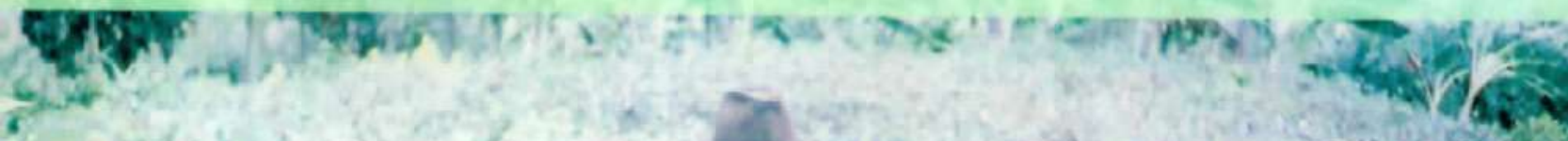

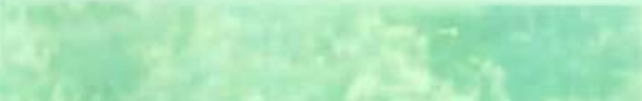

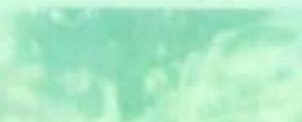

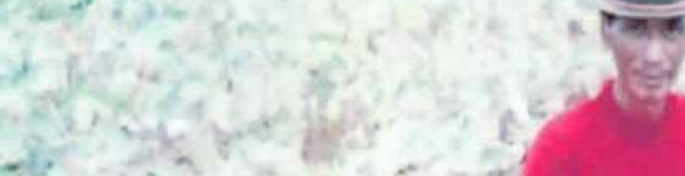

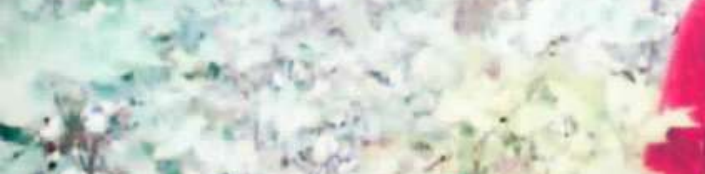

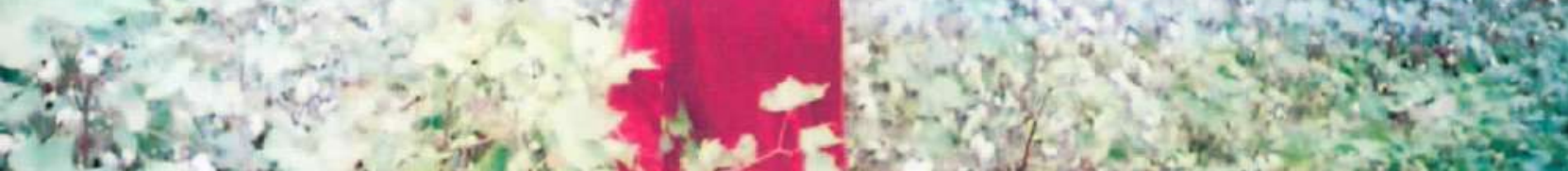

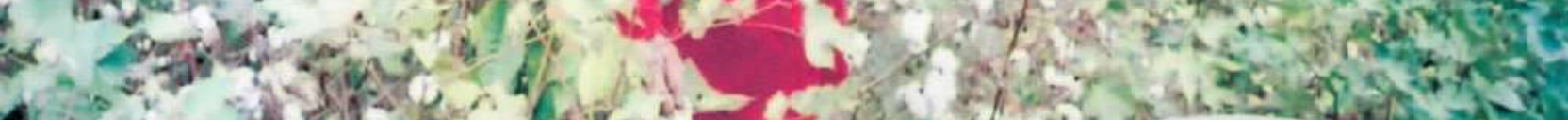

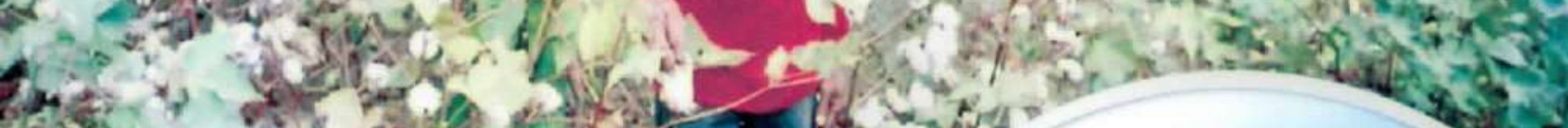

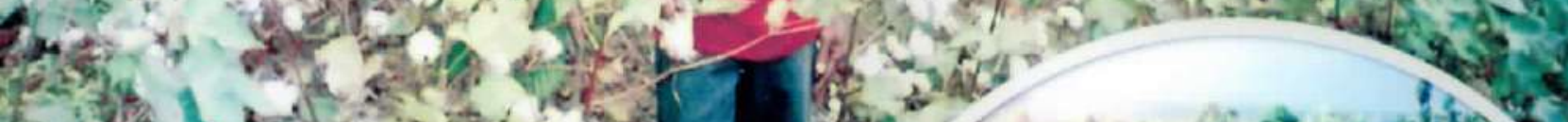
the $6 x^{2}+x^{2}$ Junaedi 


\title{
PENGEMBANGAN KAPAS RAKYAT DI SULAWESI SELATAN
}

Kajian Terhadap Efisiensi Produksi \& Daya Saing

\author{
J u n a e d i
}

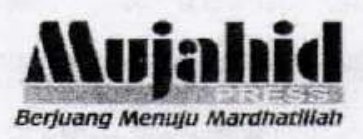




\title{
PENGEMBANGAN KAPAS RAKYAT DI SULAWESI SELATAN
}

Kajian Terhadap Efisiensi Produksi \& Daya Saing

\author{
Penulis : \\ J u n a ed i
}

Editor :

Syahruni Thamrin

Layout :

Mujahid Grafis

Disain Sampul :

M. Ishfan Futhifar

$\mathrm{vi}+171,15,5 \times 23 \mathrm{~cm}$

Cetakan I, Februari 2016

ISBN: 978-979-762-433-0

Diterbitkan oleh :

CV. Mujahid Press

Anggota IKAPI

Jl. Tambakan No. 06 Bojongkunci Pameungpeuk Bandung

Telp/Fax. (022) 5943620 - 08122056466

http://www.mujahidpress.com

e-mail : percetakanmujahidpress@yahoo.co.id

\section{Alujalnid




\section{PRAKATA}

Alhamdulillahi rabbil 'alamin. segala puji bagi Allah SWT_atas segala rahmat, karunia dan petunjuk-Nya sehingga buku yang menguraikan tentang kajian teoritis pengembangan kapas rakyat di Sulawesi Selatan ini dapat penulis selesaikan. Buku ini merupakan bagian dari tekad penulis untuk dapat menggambarkan sekaligus memberikan alternatif kebijakan dalam menyelesaikan sebagian dari permasalahan perkapasan nasional.

Kebijakan pengembangan kapas saat ini diarahkan pada peningkatan pengembangan partisipatif aktif petani dan semua pihak yang terkait sebagai upaya untuk meningkatkan produksi kapas nasional dan pendapatan petani. Sulawesi Selatan merupakan salah satu wilayah pengembangan dengan areal terluas. Kajian pada buku ini terkait pengembangan kapas di Sulawesi Selatan dilakukan untuk melihat sejauh mana usahatani tersebut mampu mendorong peningkatan produksi dan memberi kesempatan penerimaan yang lebih baik, sehingga komoditi tersebut memiliki nilai daya saing yang cukup sebagai komoditas strategis.

Hasil kajian yang dipaparkan pada buku ini diharapkan dapat berguna sebagai masukan dalam menentukan arah kebijakan pola pengembangan kapas rakyat, khususnya di Sulawesi Selatan hingga dapat meningkatkan dukungan pemerintah bagi pengembangan kapas rakyat. Bagi peneliti dan mahasiswa, buku ini dapat menjadi referensi sekaligus dasar penentuan kegiatan penelitianpenelitian yang terkait dengan tema yang disusun dalam buku ini

Akhirnya atas segala kekurangan dan ketidakcermatan dalam penulisan buku ini mohon kritikan dan masukan untuk lebih baik. Semoga isi buku ini dapat menjadi bagian dari sumbang pikir terhadap kondisi perkapasan nasional, sehingga mampu berkontribusi dalam pengambilan kebijakan sektor pertanian.

Makassar, 13 Januari 2016

Penulis 


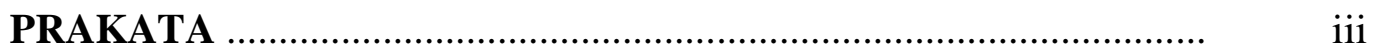

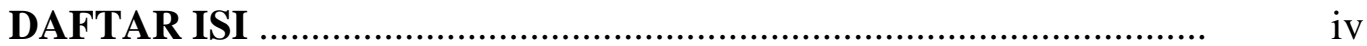

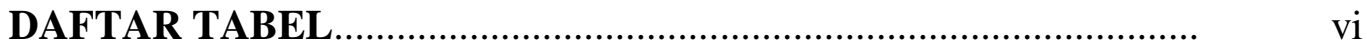

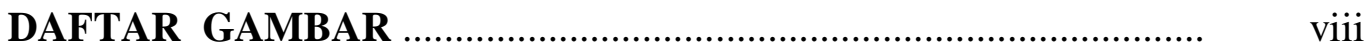

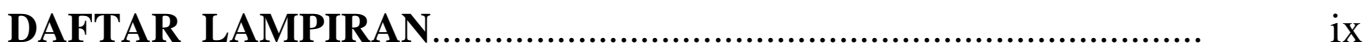

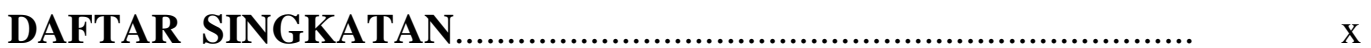

\section{BAB I. PENDAHULUAN}

1.1. Pengembangan Kapas di Indonesia..................................... 1

1.2. Program Akselerasi pengembangan Kapas.......................... 6

BAB II. EFISIENSI PRODUKSI, RISIKO DAN DAYA SAING

2.1. Produktivitas dan Efisiensi Produksi................................. 9

2.2. Perilaku Terhadap Risiko................................................... 18

2.3. Konsep Daya Saing........................................................... 23

BAB III. PENGEMBANGAN KAPAS DAN METODE ESTIMASI

3.1. Kapas di Sulawesi Selatan................................................. $\quad 30$

3.2. Pengukuran Efisiensi Produksi Komoditas Pertanian........... 33

3.3. Kajian Perilaku Terhadap Risiko........................................... $\quad 40$

3.4. Daya Saing dalam Produksi Kapas.................................... 45

3.5. Studi Pengembangan Kapas di Sulawesi Selatan.................. 49

3.5.1. Metode Dasar........................................................ 49

3.5.2. Penentuan Lokasi ..................................................... 49

3.5.3. Pengumpulan Data dan Informasi............................ 50

3.5.4. Definisi Operasinal dan Pengukuran Variabel............ 51

3.5.5. Metode Analisisi Data............................................... 52

BAB IV. DESKRIPSI WILAYAH DAN KARAKTERISTIK PETANI KAPAS DI SULAWESI SELATAN

4.1. Deskripsi Wilayah ........................................................... 71

4.2. Kebijakan Pengembangan Kapas ........................................ 73

4.3. Karakteristik Petani ........................................................... $\quad 74$

4.4. Penerapan Teknologi Usahatani Kapas di Sulsel................ 78

BAB V. ANALISIS FUNGSI PRODUKSI DAN EFISIENSI PRODUKSI

5.1. Analisis Fungsi Produksi Stochastic Frontier .................... 82

5.2. Tingkat Efisiensi Teknis dan Inefisiensi Teknis ................. 92

5.2.1. Sebaran Efisiensi Teknis............................................. 92

5.2.2. Sumber Inefisiensi Teknis.......................................... 95

5.3. Efisiensi Ekonomi dan Alokatif ............................................ 99

5.4. Perilaku Petani Terhadap Risiko Produksi Usahatani Kapas.. 102

5.5. Hubungan Antara Efisiensi teknis dan Perilaku Petani........... 105 


\section{BAB VI. ANALISIS DAYA SAING USAHATANI KAPAS}

6.1. Analisis Daya Saing Usahatani

6.2. Daya Saing Kapas Melalui Akselerasi Pengembangan

Kapas Rakyat

6.2.1. Analisis Daya Saing

6.2.2. Analisis Dampak Kebijakan Pemerintah Terhadap Output

6.2.3. Analisis Dampak Kebijakan Pemerintah Terhadap Input

6.2.4. Analisis Dampak Kebijakan Pemerintah Terhadap Input-Output

6.3. Analisis Sensitivitas

6.4. Hubungan Antara Efisiensi Teknis dan Daya Saing

BAB VII. PENUTUP

7.1. Kesimpulan

7.2. Implikasi Kebijakan. 


\section{DAFTAR TABEL}

No

Uraian

Halaman

1.1 Rata-rata Laju Pertumbuhan dan Kontribusi Areal Produksi Kapas di Indonesia, 1970 - 2008

1.2 Sasaran Areal Penanaman Kapas di Sulawesi Selatan

3.1 Review Penelitian Tentang Efisiensi Komoditas Pertanian

3.2 Review Penelitian Tentang Perilaku Petani Terhadap Risiko

3.3 Review Penelitian Tentang Daya Saing Komoditi

3.4 Sebaran Sampel Penelitian Menurut Lokasi Penelitian

3.5 Formulasi Model Policy Analysis Matrix (PAM)

4.1 Luas Wilayah Provinsi Sulawesi Selatan dirinci Menurut Kabupaten

4.2 Deskripsi Statistik Petani Kapas di Sulawesi Selatan

4.3 Sebaran Petani Responden Berdasarkan Kelompok Umur

4.4 Sebaran Petani Responden Berdasarkan Pengalaman Usahatani

4.5 Sebaran Petani Responden Berdasarkan Tingkat Pendidikan Formal

4.6 Sebaran Petani Responden Berdasarkan Jumlah Anggota Keluarga

4.7 Sebaran Petani Responden Berdasarkan Lama Bergabung Dalam Kelompok Tani

5.1 Fungsi Produksi Stochastic Frontier Usahatani Kapas dengan Metode MLE

5.2 Deskripsi Statistik Input Produksi Kapas per Hektar di Sulsel

5.3 Deskripsi Statistik Input Kapas per Usahatani di Sulsel

5.4 Sebaran Efisiensi Teknis Usahatani Kapas Petani Responden di Sulawesi Selatan Menurut Kabupaten

5.5 Sebaran Efisiensi Teknis Usahatani Kapas Petani Responden di Sulawesi Selatan 
5.6 Rata-rata Tingkat Penggunaan Input Usahatani Kapas di Sulawesi

Selatan Menurut Kabupaten

5.7 Fungsi Produksi Stochastic Frontier Model Inefisiensi Usahatani Kapas dengan Metode MLE

5.8 Fungsi Biaya Produksi Stochastic Frontier Usahatani Kapas dengan Metode MLE

5.9 Efisiensi Teknis, Efisiensi Ekonomi dan Efisiensi Alokatif Usahatani Kapas di Sulawesi Selatan

102

5.10 Analisis Produksi Usahatani Kapas untuk Menentukan Input yang Berpengaruh

5.11 Perilaku Petani Terhadap Risiko Usahatani Kapas di Sulawesi Selatan

5.12 Sebaran Perilaku Petani Beradasarkan Tingkat Efisiensi Teknis Usahatani Kapas Petani Responden di Sulawesi Selatan

5.13 Hasil Analisis Korelasi Antara Efisiensi Teknis dan Perilaku Petani Kapas di Sulawesi Selatan

5.14 Hubungan Tingkat Efisiensi dan Perilaku Petani Kapas

6.1 Policy Analysis Matrix Usahatani Kapas Rakyat di Sulawesi Selatan (Rp/ha)

6.2 Indikator-Indikator Policy Analysis Matrix Usahatani Kapas Rakyat di Sulawesi Selatan

6.3 Policy Analysis Matrix Usahatani Kapas Rakyat di Sulsel dengan Memperhitungkan Bantuan Input (Rp/ha)

6.4 Indikator-Indikator Policy Analysis Matrix Pada Usahatani Kapas Mempertimbangkan Bantuan Input

6.5 Sebaran Keunggulan Kompetitif Usahatani Kapas di Sulawesi Selatan

6.6 Sebaran Keunggulan Komparatif Usahatani Kapas di Sulawesi Selatan

6.7 Indikator - Indikator Policy Analysis Matrix Usahatani Kapas di Sulawesi Selatan Mempertimbangkan Bantuan Input

6.8 Indikator - Indikator Policy Analysis Matrix Usahatani Kapas di Sulawesi Selatan Mempertimbangkan Bantuan Input Terhadap Input

6.9 Indikator - Indikator Policy Analysis Matrix Usahatani Kapas di Sulawesi Selatan Mengenai Dampak Kebijakan Terhadap InputOutput

6.10 Analisis Sensitivitas Usahatani Kapas Bila Terjadi Perubahan 
6.11 Hasil Analisis Korelasi Antara Efisiensi Teknis dan Daya Saing Petani Kapas di Sulawesi Selatan

6.12 Hubungan Tingkat Efisiensi dan Daya Saing Usahatani Kapas

\section{DAFTAR GAMBAR}

No

Uraian

Halaman

1.1 Kontribusi Produksi Kapas Sentra Produksi Kapas di Indonesia

1.2 Perkembangan Produksi Kapas Sul-Sel 2004 - 2008

2.1 Ukuran Efisiensi Produksi Berorientasi Input 12

2.2 Fungsi Produksi Stochastic Frontier 16 


\section{DAFTAR LAMPIRAN}

1. Peta Administrasi Provinsi Sulawesi Selatan

2. Peta Lokasi Pengembangan Kapas Rakyat di Sulawesi Selatan 138

3. Peta Lokasi Penelitian 139

4. Hasil Estimasi Fungsi Produksi Usahatani Kapas Rakyat di 140 Sulawesi Selatan

5. Hasil Estimasi Fungsi Biaya Usahatani Kapas Rakyat di Sulawesi Selatan

6. Hasil Regresi Fungsi Produksi untuk Menentukan Input Yang Paling Berpengaruh Menggunakan SPSS

7. Hasil Perhitungan Parameter Perilaku Terhadap Risiko Usahatani Kapas Rakyat di Sulawesi Selatan

8. Perhitungan Nilai Tukar Bayangan

9. Perhitungan Harga Bayangan Serat Kapas (output)

10. Perhitungan Harga Bayangan Benih Kapas

11. Perhitungan Harga Bayangan Pupuk Urea

12. Perhitungan Harga Bayangan Pupuk SP-36, ZA dan NPK

13. Input-Output, Harga dan Budget Usahatani Kapas Rakyat di Sulawesi Selatan

14. Hasil Perhitungan Policy Analysis Matrix Usahatani Kapas

15. Input-Output, Harga dan Budget Usahatani Kapas Rakyat di Sulawesi Selatan dengan Memperhitungkan Bantuan Sosial

16. Hasil Perhitungan Policy Analysis Matrix Usahatani Kapas Memperhitungkan Bantuan Sosial

17. Hasil Estimasi Fungsi Produksi, Perilaku dan Daya Saing Usahatani Kapas Rakyat di Sulawesi Selatan 


\section{DAFTAR SINGKATAN}

$$
\begin{aligned}
& \mathrm{AE}=\text { Allocative Efficiency (efisiensi alokatif) } \\
& \text { Bnh = Jumlah benih } \\
& \text { Bprod }=\text { Total Biaya Produksi } \\
& \text { BProd = Total biaya produksi kapas } \\
& \mathrm{CE} \quad=\text { Cost Efficiency } \\
& \mathrm{CIF}=\text { Coct, Insurance and Freight } \\
& \text { DEA = Data Envelopment Analysis } \\
& \text { DRC = Domestic Resource Cost Ratio } \\
& \mathrm{EE} \quad=\text { Economic Efficiency (efisiensi ekonomi) } \\
& \mathrm{EPC}=\text { Effective Protection Coefficient } \\
& \text { FOB }=\text { Free on Board } \\
& \text { FT }=\text { Transferfaktor } \\
& \text { Her = Jumlah herbisida } \\
& \text { Hher = Harga herbisida } \\
& \text { HIns = Harga insektisida } \\
& \mathrm{HNpk}=\text { Harga pupuk NPK } \\
& \text { HSp = Harga pupuk SP-36 } \\
& \text { HST = Hari setelah tanam } \\
& \text { HTk = Upah tenaga kerja } \\
& \text { Hur = Harga pupuk Urea } \\
& \text { IKR = Intensitas Kapas Rakyat } \\
& \text { Ins } \quad=\text { Jumlah insektisida } \\
& \text { IT }=\text { Transfer Input } \\
& \mathrm{Kt}=\text { Lama bergabung dalam kelompok tani } \\
& \text { Lh = Luas lahan } \\
& \text { MLE = Maximum Likelihood Estimates } \\
& \text { MPL = Minggu tanam paling lambat } \\
& \text { NPCI = Nominal Protection Coefficient on Tradable Input } \\
& \text { NPCO = Nominal Protection Coefficient on Tradable Output }
\end{aligned}
$$




$$
\begin{aligned}
& \mathrm{Npk}=\text { Jumlah pupuk NPK } \\
& \text { NT }=\text { Netto Transfer } \\
& \text { OER = Official Exchange Rate } \\
& \text { OLS = Ordinary Least Square } \\
& \text { OPT = Organisme Pangganggu Tanaman } \\
& \text { OT = Output Transfer } \\
& \text { PAM = Policy Analysis Matrix } \\
& \text { PBN = Perkebunan Besar Negara } \\
& \text { PBS = Perkebunan Besar Swasta } \\
& \mathrm{PC}=\text { Profitability Coefficient } \\
& \mathrm{PCR}=\text { Private Cost Ratio } \\
& \mathrm{Pd} \quad=\text { Pendidikan formal } \\
& \text { Pgl = Pengalaman usahatani } \\
& \mathrm{PP} \quad=\text { Private Profitability (keuntungan privat) } \\
& \mathrm{PR} \quad=\text { Perkebunan Rakyat } \\
& \text { Prod = Produksi kapas } \\
& \text { Rt = Jumlah anggota rumah tangga } \\
& \text { SCF = Standard Convertion Factor } \\
& \text { SER = Shadow Exchange Rate } \\
& \text { SFA = Stochastic Frontier Analysis } \\
& \mathrm{Sp} \quad=\text { Jumlah pupuk SP-36 } \\
& \mathrm{SP} \quad=\text { Social Profitability (keuntungan sosial) } \\
& \text { SRP = Subsidy Ratio to Producer } \\
& \mathrm{TE} \quad=\text { Technical Efficiency (efisiensi teknis) } \\
& \mathrm{Tk}=\text { Jumlah tenaga kerja } \\
& \mathrm{TPT}=\text { Tekstil dan Produksi Tekstil } \\
& \mathrm{Um}=\text { Umur petani } \\
& \mathrm{Ur} \quad=\text { Jumlah pupuk Urea } \\
& \mathrm{Za}=\text { Jumlah pupuk ZA }
\end{aligned}
$$




\section{PENDAHULUAN}

\subsection{Pengembangan Kapas di Indonesia}

Kapas merupakan salah satu bahan baku industri yang memegang peranan penting dalam perekonomian nasional karena kapas merupakan komoditas utama penghasil serat alam untuk bahan baku industri Tekstil dan Produksi Tekstil (TPT). Serat kapas hingga kini peranannya masih lebih besar dari pada serat sintesis, terutama di negara-negara beriklim tropik. Hingga kini, 90\% bahan baku untuk kebutuhan tekstil dunia diperoleh dari serat kapas, dan sisanya $10 \%$ diperoleh dari serat sintesis.

Kebutuhan industrial tekstil akan serat kapas terus meningkat sejalan dengan bertambahnya penduduk. Namun kemajuan industri tekstil belum sepenuhnya mendapat dukungan dalam penyediaan bahan baku. Kebutuhan bahan baku masih bergantung pada kapas impor. Baru sekitar 0,5\% yang mampu dihasilkan dalam negeri (Ibrahim, 2008). Pada tahun 2010 misalnya, produksi kapas nasional hanya sekitar 26.000 ton, dari total kebutuhan kapas nasional yang mencapai 550.000 ton per tahun. Bahkan pada tahun 2011, impor kapas dari Amerika Serikat pada periode Januari-April melesat tinggi, berdasarkan data Badan Pusat Statistik (BPS), nilai impor kapas dari negeri Paman Sam itu pada Januari-April 2011 sebesar US\$ 324.594.550. Nilai ini melonjak 373,12\% dibandingkan Januari-April 2010 yang sebesar US\$ 68.607.242 (Arsip.com, 2011).

Produksi kapas Indonesia selama ini didominasi oleh produksi yang berasal dari Perkebunan Rakyat (PR) dengan kontribusi rata-rata tahun 1970-2008 mencapai 93,49\%, sedangkan Perkebunan Besar Negara (PBN) dan Perkebunan Besar Swasta (PBS) masing-masing hanya memberikan kontribusi sebesar 5,40\% dan $1,11 \%$ (Tabel 1.1). 
Di Indonesia terdapat tiga status pengusahaan perkebunan yaitu Perkebunan Rakyat (PR), Perkebunan Besar Negara (PBN) dan Perkebunan Swasta (PBS). Pada periode tahun 1970-2008 sebagian besar luas areal perkebunan kapas di Indonesia dikuasai oleh PR dengan persentase 94,20\% dari total luas areal kapas di Indonesia. Kontribusi luas areal PR setelah tahun 1985 menunjukkan kenaikan dibandingkan sebelumnya karena adanya pengalihan dan fokus ke komoditas lain seperti untuk pengembangan perkebunan kelapa sawit dan karet. Namun dari sisi pertumbuhannya, luas areal PR setelah tahun 1985 justru cenderung menurun dengan rata-rata penurunan sebesar $0,60 \%$ per tahun.

Tabel 1.1. Rata-rata Laju Pertumbuhan dan Kontribusi Areal Produksi Kapas di Indonesia, 1970 - 2008

\begin{tabular}{|c|c|c|c|c|c|c|c|c|}
\hline \multirow{2}{*}{ Tahun } & \multicolumn{4}{|c|}{ Luas Areal } & \multicolumn{4}{|c|}{ Produksi } \\
\hline & PR & PBN & PBS & Total & PR & PBN & PBS & Total \\
\hline \multicolumn{9}{|c|}{ Pertumbuhan (\% } \\
\hline $1970-2008$ & 65.56 & 30.95 & -29.47 & 34.70 & 44.01 & 12.69 & 32.79 & 34.53 \\
\hline $1970-1985$ & 167.01 & 37.56 & 2.08 & 88.94 & 71.57 & 36.67 & 164.81 & 47.71 \\
\hline 1986-2008 & -0.60 & 6.16 & -52.00 & -0.68 & 26.03 & -77.22 & -61.52 & 25.93 \\
\hline \multicolumn{9}{|c|}{ Kontribusi (\%) } \\
\hline $1970-2008$ & 94.20 & 4.56 & 1.27 & 100.00 & 93.49 & 5.40 & 1.11 & 100.00 \\
\hline $1970-1985$ & 84.57 & 12.28 & 3.16 & 100.00 & 83.58 & 13.78 & 2.64 & 100.00 \\
\hline 1986-2008 & 99.43 & 0.37 & 0.21 & 100.00 & 99.81 & 0.06 & 0.13 & 100.00 \\
\hline
\end{tabular}

Sentra produksi kapas di Indonesia terdapat di Provinsi Sulawesi Selatan, Jawa Timur, Nusa Tenggara Barat dan Jawa Tengah. Sulawesi Selatan (Sulsel) merupakan provinsi sentra produksi kapas terbesar dengan kontribusi rata-rata sebesar 48,60\%, diikuti oleh Jawa Timur (Jatim) dengan kontribusi rata-rata sebesar 11,81\%. Nusa Tenggara Barat (NTB) berada di posisi ketiga dengan kontribusi rata-rata sebesar 9,74\%, sedangkan Jawa Tengah (Jateng) yang luas arealnya lebih besar daripada Nusa Tenggara Barat (NTB) ternyata hanya memberikan kontribusi 8,32\% (Gambar 1.1). 


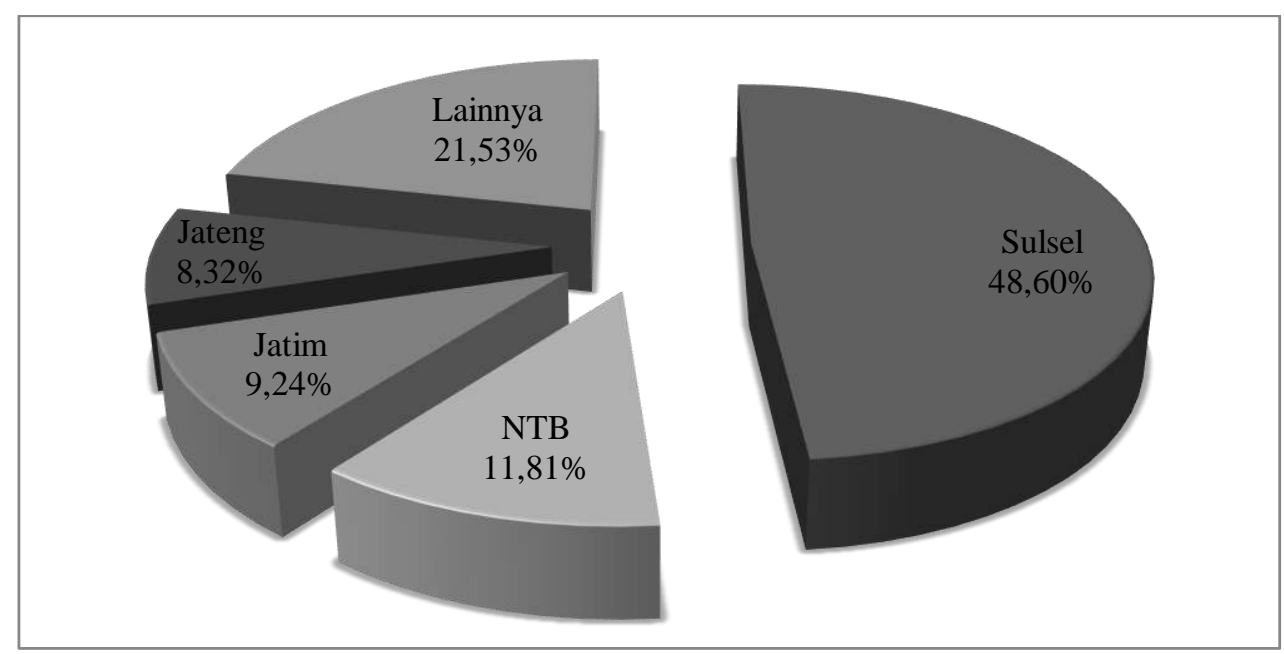

Gambar 1.1. Kontribusi Produksi Kapas Sentra Produksi Kapas di Indonesia (Sumber : Ditjenbun, 2010)

Rendahnya kinerja perkapasan nasional selama ini menurut Rachman (2007) disebabkan oleh beberapa faktor antara lain; (a) Diusahakan pada lahan marginal yaitu lahan-lahan dengan faktor pembatas ketersediaan air dan ditanam setelah penanaman komoditi utama bagi petani seperti padi/palawija secara tumpang sari atau tumpang gilir, (b) Teknologi anjuran tidak diterapkan sepenuhnya oleh petani karena lemahnya permodalan, walaupun tehnik budidaya kapas telah dikuasainya, dan (c) Benih yang digunakan umumnya berasal dari varietas lokal yang tidak unggul dibandingkan dengan varietas introduksi seperti transgenik, yang pernah dikembangkan secara terbatas pada tahun 2001-2002.

Guna mendukung pengembangan kapas di Indonesia maka pemerintah melalui program akselerasi tahun 2011 menargetkan pengembangan kapas dari masing-masing provinsi wilayah pengembangan kapas seluas 15.900 ha, mencakup; Jateng 1.000 ha, Jatim 2.050 ha, DIY 750 ha, Bali 800 ha, NTB 800 ha dan NTT 3.500 ha serta Sulsel 7.000 ha (Ditjenbun, 2010). Disamping itu dukungan perusahaan pengelola yang diharapkan antara lain melalui optimalisasi ginnery, yang tersebar di Jateng, Jatim Timur, NTB, NTT, Sulsel dan Sultra.

Di Sulawesi Selatan, kapas merupakan prioritas kedua dalam pembangunan sub sektor perkebunan setelah kakao. Sentra pengembangannya 
meliputi Kabupaten Gowa, Takalar, Jeneponto, Bantaeng, Bulukumba, Bone, Soppeng, dan Wajo. Mengacu pada ketersediaan sumberdaya lahan, potensial areal untuk penanaman kapas di wilayah Sulsel seluas 518.910 hektar, terdiri dari lahan kering 335.003 hektar dan lahan sawah bero seluas 183.907 hektar yang tersebar pada 16 wilayah kabupaten (Ditjenbun, 2001). Namun areal yang menjadi sasaran penanaman pada sentra pengembangan kapas secara umum di tunjukkan pada Tabel 1.2.

Tabel 1.2. Sasaran Areal Penanaman Kapas di Sulawesi Selatan

\begin{tabular}{lrrr}
\hline \multirow{2}{*}{ Kabupaten } & \multicolumn{3}{c}{ Sasaran areal (hektar) } \\
\cline { 2 - 4 } & TMP & TMK & Jumlah \\
\hline Bantaeng & 2.500 & 100 & 2.600 \\
Bulukumba & 3.000 & 200 & 3.200 \\
Bone & 250 & 100 & 350 \\
Soppeng & 500 & 100 & 600 \\
Wajo & 500 & 100 & 600 \\
Gowa & - & 250 & 250 \\
Takalar & - & 400 & 400 \\
\hline Jumlah & 6.750 & 1.250 & 8.000 \\
\hline
\end{tabular}

Sumber : Data Pengembangan Kapas Transgenik, Disbun Sulsel, 2001

Keterangan : TMP $=$ Tanam Musim Penghujan TMP $=$ Tanam Musim Kemarau

Produksi kapas pada tahun 2010 yang terdapat di Kabupaten Bone, Soppeng, dan Wajo mencapai $1.800 \mathrm{~kg}$ per hektarnya. Adapun Jumlah area yang ditanami seluas 7.700 hektar. Namun produksinya belum mampu mencapai target yaitu 2.500 - $3.000 \mathrm{~kg}$ per hektarnya. Secara umum perkembangan produksi kapas Sulsel mengalami peningkatan selama periode 2004-2008. Perkembangan produksi kapas di Sulsel dapat dilihat pada Gambar 1.2. 


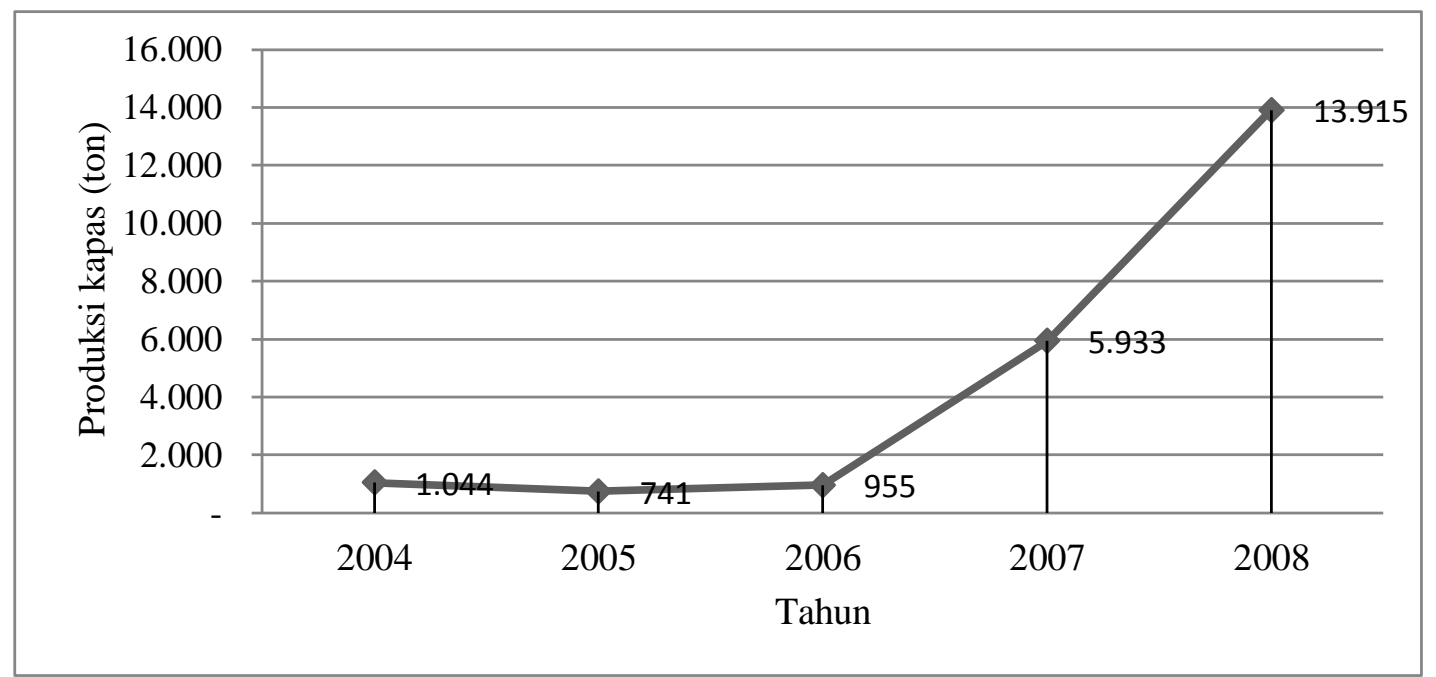

Gambar 1.2. Perkembangan Produksi Kapas Sulsel 2004 - 2008 (Sumber : Ditjenbun, 2010)

Sulawesi Selatan diharapkan mampu mendongkrak pengembangan produksi komoditas kapas untuk memenuhi permintaan kebutuhan kapas yang merupakan bahan baku tekstil. Untuk memacu pengembangan tersebut, Sulsel pada tahun 2011 mengimpor benih kapas dari China sebanyak 25.896 ton. Benih tersebut merupakan varietas unggul baru jenis HSC 138 dan HSC 188, jenis ini memiliki keunggulan potensi produksi yang bagus serta tidak rentan terhadap serangan hama ulat. Penetapan sumber benih kapas ini bedasarkan SK Dirjen Perkebunan No. 40/Kpts/SR.120/02/2010.

Sementara itu, untuk meningkatkan minat petani menanam kapas, pemerintah memberi bantuan produksi berupa benih dan pupuk, serta menetapkan harga pembelian oleh pengusaha dari petani sebesar Rp 4.000/ kg. Sebelumnya, kapas dari petani hanya dihargai $\mathrm{Rp} 2.500 / \mathrm{kg}$. Selain pengembangan demplot, pemerintah provinsi juga mendapatkan alokasi dana dari pemerintah pusat sebesar Rp 1,8 juta rupiah per hektarnya yang dialokasikan untuk penyediaan benih bagi petani kapas yang ada di Sulsel.

Berdasarkan kondisi tersebut, maka permasalahan produksi tanaman kapas dikaitkan dengan adanya kebijakan perkapasan berupa bantuan input produksi dan penetapan harga pembelian serat kapas menjadi topik yang menarik 
untuk dikaji karena dengan terjadinya perubahan harga ditingkat petani diharapkan mampu mendorong perluasan penanaman kapas sekaligus meningkatkan produksi yang diharapkan memberi kontribusi terhadap pemenuhan kebutuhan industri tekstil nasional.

Tindakan pemerintah untuk mendongkrak produksi kapas nasional dengan memberikan bantuan input (benih, pupuk, dan pestisida) dalam pengembangan kapas rakyat merupakan kebijakan penting dalam mengatasi kendala permodalan. Benih yang selama ini diributkan kesulitannya dalam pengadaan benih bermutu dalam jumlah banyak sudah dapat teratasi, melalui penggunaan benih unggul hibrida. Masalahnya harga benih yang masih mahal sehingga perlu disubsidi, begitu pula terhadap kebutuhan saprodi yang lain seperti pupuk, sehingga diharapkan pendapatan petani meningkat dengan adanya subsidi berupa bantuan saprodi dan minat petani mengembangkan kapas juga meningkat. Disisi lain langkah menaikkan harga kapas berbiji, dengan sendirinya menjadi acuan penting bagi petani dalam pengambilan keputusan usahataninya, dimana kapas akan diperhadapkan dengan beberapa komoditi utama lainnya.

\subsection{Program Akselerasi Pengembangan Kapas}

Upaya untuk terus meningkatkan kontribusi kapas produksi dalam negeri pada Industri TPT nasional sekaligus terus mengurangi ketergantungan impor kapas, dilaksanakan pemerintah melalui percepatan peningkatan luas areal dan produksi kapas (Program Akselerasi Pengembangan Kapas) dengan dukungan;

a) Penyediaan benih secara tepat jenis, tepat mutu, tepat jumlah dan tepat lokasi;

b) Dukungan bantuan pupuk;

c) Pelatihan petani;

d) Penyediaan tenaga pendamping lapangan;

e) Memanfaatkan secara optimal dukungan fungsi terkait;

f) Penetapan harga kapas berbiji;

g) Rayonisasi perusahaan pengelola, serta

h) Terus mendorong pihak swasta untuk melakukan investasi secara serius di on-farm kapas. 
Program akselerasi pengembangan kapas merupakan upaya percepatan peningkatan produksi kapas dalam rangka meningkatkan pemenuhan kebutuhan serat kapas sebagai bahan baku industri tekstil dalam negeri sampai dengan 5\% mulai tahun 2014. Dukungan perusahaan pengelola yang diharapkan antara lain; optimalisasi ginnery, fasilitasi kredit perbankan (sebagai avalis), pembangunan kebun benih kapas unggul dan penampungan hasil.

Melihat faktor-faktor internal dan eksternal, peluang pengembangan kapas di Sulsel masih besar dengan pertimbangan sebagai berikut.

(1) Ketersediaan pasar, kebutuhan serat kapas untuk industri tekstil 99,5\% masih impor, ini adalah peluang pasar bagi komoditas kapas Indonesia termasuk Sulsel, yang diharapkan mampu mengangkat tingkat kesejahteraan petani.

(2) Dukungan sektor agroindustri, di Sulsel terdapat dua unit mesin processing yang mampu memisahkan biji dengan serat kapas, masing-masing di Bulukumba dan Jeneponto. Kapasitas giling kedua mesin mencapai hampir 40 ribu ton kapas,

(3) Kebijakan pemerintah, khususnya subsidi langsung berupa bantuan input (benih, pupuk, dan pestisida) dan penetapan kenaikan harga pembelian kapas berbiji yang terus ditingkatkan.

Berdasarkan faktor-faktor pendukung tersebut, pengembangan kapas di Sulawesi Selatan perlu diteruskan dengan berbagai perbaikan-perbaikan. Tingkat kinerja penerapan teknologi sistem produksi kapas melalui terobosan baru dalam penggunaan varietas kapas hibrida diharapkan mampu meningkatkan kontribusi usahatani kapas terhadap pendapatan petani serta berkontribusi terhadap pertumbuhan ekonomi wilayah.

Data menunjukkan bahwa tingkat produktivitas dan efisiensi produksi masih rendah, hal ini salah satunya disebabkan karena tingkat biaya produksi yang tinggi dan penerimaan harga kapas petani yang masih rendah, sehingga melalui kebijakan subsidi bantuan input dan peningkatan harga pembelian kapas berbiji diharapkan peningkatan pendapatan, yang sekaligus dapat mendorong petani 
untuk bersedia mengambil risiko dalam pengembangan kapas rakyat. Mengingat bahwa umumnya usaha pertanian akan mengalami kendala dari sisi harga produk dan tingginya pengeluaran input, sehingga petani cenderung mengusahakan tanaman yang memiliki tingkat kendala paling kecil.

Berdasarkan uraian di atas, maka pengembangan kapas rakyat di Sulawesi Selatan perlu dicermati dan dianalisis untuk menjawab beberapa pertanyaan sebagai berikut;

1. Apakah usahatani kapas yang dilakukan di Sulawesi Selatan telah efisien dalam pemanfaatan input produksi dan pengalokasian sumberdaya?

2. Bagaimana perilaku petani kapas terhadap risiko produksi pada usahataninya?

3. Bagaimana daya saing kapas di Sulawesi Selatan setelah adanya kebijakan terkait akselerasi pengembangan kapas nasional ?

4. Apakah terdapat hubungan antara efisiensi dan perilaku serta efisiensi dan daya saing usahatani kapas di Sulawesi Selatan ?

Berdasarkan rumusan masalah tersebut buku ini mencoba mengkaji halhal terkait;

1. Tingkat efisiensi teknis, efisiensi alokatif dan efisiensi ekonomi usahatani kapas rakyat di Sulawesi Selatan.

2. Perilaku petani terhadap risiko produksi usahatani kapas di Sulawesi Selatan.

3. Tingkat daya saing usahatani kapas rakyat di Sulawesi Selatan.

4. Hubungan antara efisiensi dan perilaku petani serta daya saing usahatani kapas rakyat di Sulawesi Selatan.

Hal ini diharapkan dapat berguna bagi: 1) Pemerintah, berupa masukan dalam menentukan kebijakan pola pengembangan kapas rakyat, khususnya di Sulawesi Selatan. 2) Lembaga terkait, untuk meningkatkan dukungannya bagi pengembangan kapas rakyat., serta bagi peneliti, sebagai bahan informasi sekaligus dasar penentuan kegiatan penelitian-penelitian yang terkait dengan tema yang disusun dalam buku ini. 


\section{EFISIENSI PRODUKSI, RISIKO DAN DAYA SAING}

\subsection{Produktivitas dan Efisiensi Produksi}

Produksi merupakan transformasi input menjadi output (Adegeye dan Dittoh,1985). Menurut Beattie dan Taylor (1985) produksi adalah hasil kombinasi dan koordinasi beberapa material dan beberapa kekuatan (berupa input, faktor, sumber daya atau jasa produksi) untuk menciptakan suatu barang atau jasa (output atau produk). Istilah produktivitas mengacu pada efisiensi input produksi yang ditransformasikan ke output dalam proses produksi. Produktivitas merupakan perbandingan antara hasil yang dicapai dengan keseluruhan sumber daya yang digunakan. Pengertian produktivitas secara teknis adalah pengefisiensian produksi terutama dalam pemakaian ilmu dan teknologi. Produktivitas dapat ditingkatkan dengan cara menurunkan input dan meningkatkan output.

Menurut Pindyck dan Rubinfeld (2007) hubungan input dan output untuk setiap sistem produksi adalah fungsi dari karakteristik teknologi. Efisiensi merupakan hasil perbandingan antara output fisik dan input fisik. Semakin tinggi rasio output terhadap input maka semakin tinggi tingkat efisiensi yang dicapai. Menurut Yotopoulos dan Nugent (1976) efisiensi produksi merupakan pencapaian output maksimum dari penggunaan sumberdaya tertentu, dimana jika output yang dihasilkan semakin besar dari sumberdaya yang digunakan maka semakin tinggi pula tingkat efisiensi yang dicapai.

Farrell (1957) yang mula-mula memperkenalkan metoda sederhana untuk mengukur efisiensi petani berdasarkan data observasi langsung, dalam kasus output tunggal dengan melibatkan banyak input. Selanjutnya Farrell (1957) mengembangkan literatur untuk melakukan estimasi empiris terkait efisiensi teknis (tehcnical efficiency/TE), efisiensi alokatif (allocative efficiency/AE), dan efisiensi ekonomi (economic efficiency/EE). 
Efisiensi teknis (TE) didefinisikan sebagai kemampuan seorang produsen atau petani untuk mendapatkan output maksimum dari penggunaan sejumlah input. Efisiensi teknis berhubungan dengan kemampuan petani untuk berproduksi pada kurva batas isoquant (frontier isoquant). Dapat juga didefinisikan sebagai kemampuan petani untuk memproduksi pada tingkat output tertentu dengan menggunakan input minimum pada tingkat teknologi tertentu. Lau dan Yotopoulos (1971) mengemukakan, seorang produsen lebih efisien secara teknis daripada produsen lainnya, apabila secara konsisten mampu menghasilkan produk yang lebih tinggi, dengan menggunakan faktor produksi yang sama. Menurut Widodo (2008) efisiensi teknis mengukur berapa produksi yang dapat dicapai dari satu set input tertentu. Hal ini menggambarkan keadaan pengetahuan teknis dan modal tetap yang dikuasai, sering disebut efisiensi jangka panjang.

Efisiensi alokatif (AE) oleh Farell (1957) didefinisikan sebagai kemampuan petani untuk memilih tingkat penggunaan input minimum pada harga-harga faktor produksi dan teknologi tetap. Menurut Widodo (2008) efisiensi harga berhubungan dengan keberhasilan petani dalam mencapai keuntungan maksimum. Secara ringkas Soekartawi (1993) menyatakan bahwa efisiensi alokatif menjelaskan kemampuan petani dalam menghasilkan sejumlah output pada kondisi minimisasi rasio biaya input. Efisiensi alokatif dikatakan tercapai apabila nilai dari produk marjinal sama dengan harga faktor produksi yang bersangkutan.

Gabungan kedua efisiensi sebelumnya, selanjutnya disebut efisiensi ekonomi (EE), artinya bahwa produk yang dihasilkan baik secara teknik maupun alokatif efisien. Hal ini juga dapat dikatakan bahwa EE sebagai kemampuan yang dimiliki oleh petani dalam berproduksi untuk menghasilkan sejumlah output yang telah ditentukan sebelumnya. Secara ekonomik dinyatakan bahwa kombinasi input-output akan berada pada fungsi produksi frontier dan jalur pengembangan usaha (expantion path). Efisiensi ekonomi dikatakan tercapai apabila usahatani tersebut dapat mencapai efisiensi teknis dan efisiensi alokatif (Soekartawi, 1993) 
Efisiensi dan inefisiensi dalam usahatani dapat diketahui melalui fungsi stochastic production frontier (SPF). Pendekatan tersebut diperkenalkan secara lebih luas oleh Aigner et al, (1977) maupun Meeusen dan Broeck (1977). Hubungan antara faktor produksi dan produksi pada frontier ditunjukkan oleh titik-titik pada garis isoquant. Garis isoquant adalah garis yang merupakan tempat kedudukan titik-titik yang menunjukkan titik kombinasi penggunaan input produksi yang optimal (Gambar 2.1.)

Pada Gambar 2.1 tersebut, kurva isoquant froentir UU' menunjukkan kombinasi input per output $\left(\mathrm{X}_{1} / \mathrm{Y}\right.$ dan $\left.\mathrm{X}_{2} / \mathrm{Y}\right)$ yang efisien secara teknis untuk menghasilkan output/produksi $\mathrm{Y}^{\mathrm{o}}=1$. Titik $\mathrm{B}$ dan $\mathrm{C}$ menggambarkan dua kondisi suatu perusahaan/usahatani dalam berproduksi menggunakan kombinasi input dengan proporsi input $\mathrm{X}_{1} / \mathrm{Y}$ dan $\mathrm{X}_{2} / \mathrm{Y}$ yang sama. Keduanya berada pada garis yang sama dari titik $\mathrm{O}$ untuk memproduksi satu unit $\mathrm{Y}^{\mathrm{o}}$. Titik $\mathrm{C}$ berada di atas kurva isoquant, sedangkan titik B menunjukkan perusahaan beroperasi pada kondisi yang secara teknis efisien (karena beroperasi pada kurva isoquant frontier). Titik B mengimplikasikan bahwa perusahaan memproduksi sejumlah output yang sama dengan perusahaan di titik $\mathrm{C}$, tetapi jumlah input yang lebih sedikit. Jadi, rasio OB/OC menunjukkan efisiensi teknis (TE) perusahaan C, yang menunjukkan proporsi dimana kombinasi input pada $\mathrm{P}$ dapat diturunkan, rasio input per output $\left(\mathrm{X}_{1} / \mathrm{Y}: \mathrm{X}_{2} / \mathrm{Y}\right)$ konstan, sedangkan output tetap.

Jika harga input tersedia maka efisiensi alokatif (AE) dapat ditentukan. garis isocost $\left(\mathrm{PP}^{1}\right)$ digambarkan menyinggung isoquant $\mathrm{UU}^{1}$ di titik $\mathrm{D}$ dan memotong garis OC di titik A. Titik A menunjukkan rasio input-output optimal yang meminimumkan biaya produksi pada tingkat output tertentu karena slope isoquant sama dengan slope garis isocost. Titik B secara teknis efisien tetapi secara alokatif inefisien karena perusahaan di titik B berproduksi pada tingkat biaya yang lebih efisien dari pada titik D. Jarak OC-OB menunjukkan penurunan biaya produksi jika produksi terjadi di titik D (secara alokatif dan teknis efisien), sehingga efisiensi alokatif (AE) untuk perusahaan yang beroperasi dititik $\mathrm{C}$ adalah rasio $\mathrm{OA} / \mathrm{OC}$. 


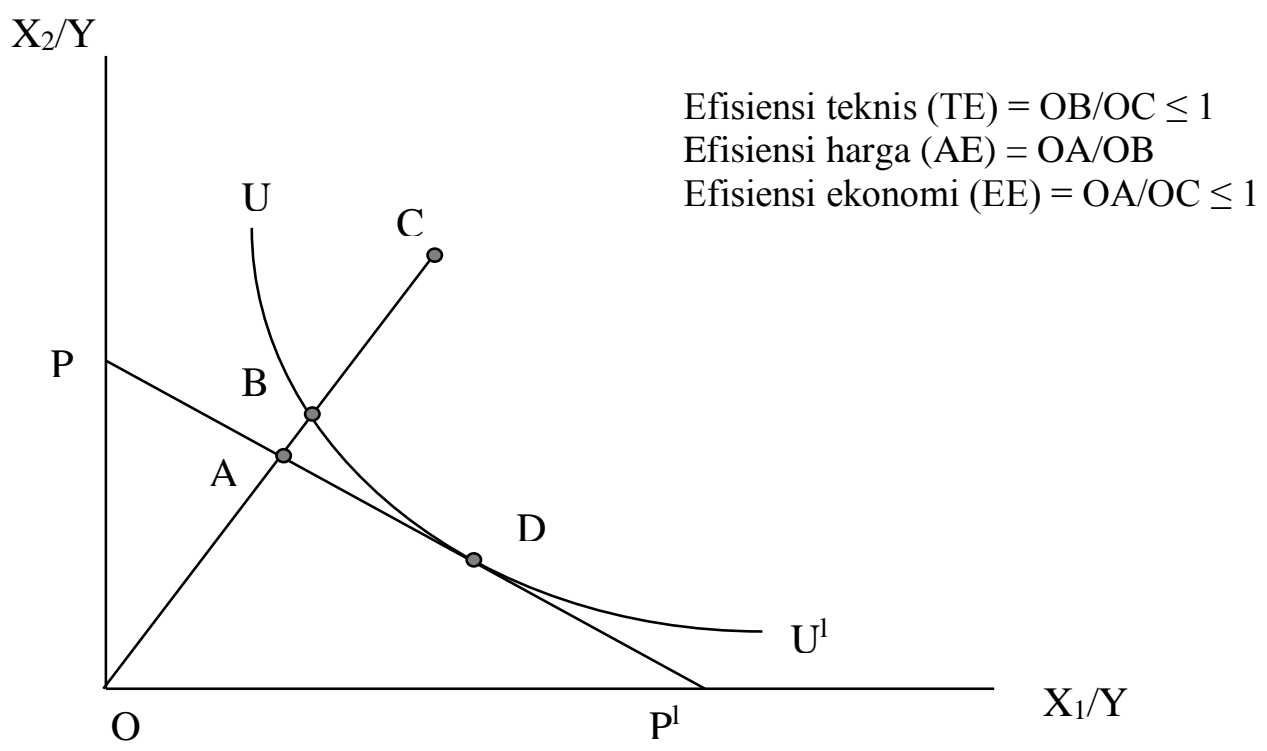

Gambar 2.1. Ukuran Efisiensi Produksi Berorientasi Input (Sumber : Farell, 1957, Soekartawi, 1994, Coelli et al. 1998)

Ellis (1988) mengemukakan bahwa terdapat empat implikasi kebijakan yang dapat dihasilkan dari pembahasan tentang efisiensi teknis, alokatif, dan ekonomis, yakni: (a) jika petani memang dibatasi oleh teknologi yang tersedia, maka hanya perubahan teknologi maju yang dapat meningkatkan kesejahteraan petani, (b) jika diasumsikan bahwa petani secara alokatif responsif terhadap perubahan harga, maka memanipulasi harga input dan output (skema kredit, subsidi pupuk) mungkin mempunyai pengaruh yang sama pada biaya yang lebih rendah, (c) jika inefisiensi terjadi akibat dari ketidaksempurnaan pasar, maka kinerja pasar seharusnya diperbaiki, dan (d) apabila petani secara teknis diketahui inefisien maka pendidikan petani dan penyuluhan pertanian perlu ditingkatkan.

\section{Pengukuran Efisiensi}

Pengukuran efisiensi produksi dapat dilakukan dengan menggunakan Data envelopment analysis (DEA) dan stochastic frontier analysis; kedua metode ini menggunakan estimasi fungsi frontier (batas), bahwa setiap input yang digunakan dalam proses produksi mempunyai kapasitas maksimum dan optimal. Pengukuran efisiensi melalui pendekatan DEA meliputi penggunaan linear 
programming dalam perhitungan efisiensi sedangkan penggunaan pendekatan stochastic frontier menggunakan metode ekonometrika.

Farrell (1957) seperti diuraikan sebelumnya, mengajukan pengukuran efisiensi yang terdiri dari dua komponen: efisiensi teknis dan efisiensi alokatif, serta gabungan keduanya yang merupakan ukuran total efisiensi ekonomi. Pengukuran efisiensi ini mengasumsikan bahwa fungsi produksi adalah produsen yang efisien secara penuh. Farrell (1957) menyarankan bahwa fungsi diestimasikan dari data sampel menggunakan non-parametric piece-wise-linear technology atau fungsi parametrik, seperti bentuk Cobb-Douglas.

Model frontier telah banyak dipakai dalam mengukur tingkat efisiensi produksi usahatani. Beberapa alasan penggunaan model frontier adalah : (1) istilah frontier adalah konsisten dengan teori ekonomi perilaku optimisasi; (2) deviasi dari frontier dengan tujuan efisiensi teknis dan perilaku unit ekonomi memiliki interpretasi alami sebagai pengukuran efisiensi; dan (3) informasi tentang efisiensi relatif unit ekonomi memiliki banyak implikasi kebijakan yang dapat diimplementasikan (Bauer, 1990).

Fungsi produksi stochastic frontier pertama kali diperkenalkan oleh Aigner et al, (1977), dan Meeusen dan Broeck (1977). Bentuk awalnya merupakan fungsi produksi yang dispesifikkan untuk data silang (cross-sectional data) dengan error term yang mempunyai dua komponen, satu disebabkan oleh random effects dan yang lain disebabkan oleh inefisiensi teknis. Model ini dapat diekspresikan dalam bentuk sebagai berikut.

$$
Y_{i}=X_{i} \beta+\left(V_{i}-U_{i}\right), \quad \quad \mathrm{i}=1, \ldots, \mathrm{n}
$$

Keterangan :

$\mathrm{Y}_{\mathrm{i}}=$ produksi (atau logaritma dari produksi) dari usahatani $\mathrm{i}$;

$\mathrm{X}_{\mathrm{i}}=$ vektor $\mathrm{k} \times 1$ dari (transformasi) jumlah output usahatani i.;

$\beta=$ vektor dari parameter yang tidak diketahui;

$\mathrm{V}_{\mathrm{i}}$ = variable random yang diasumsikan iid (identically independenly distributed). $\mathrm{N}\left(0, \sigma \mathrm{v}^{2}\right)$, 
$\mathrm{U}_{\mathrm{i}}=$ variabel non-negative random yang diasumsikan disebabkan oleh inefisiensi teknis dalam produksi dan juga sering diasumsikan sebagai iid, $\mathrm{N}\left(0, \sigma_{\mathrm{U}}^{2}\right)$.

Spesifikasi awal ini telah banyak digunakan sebagai aplikasi empiris dalam kurun waktu dua dekade terakhir. Spesifikasi ini juga telah diubah dan diperluas dalam berbagai cara. Perluasan mencakup asumsi distribusi umum untuk $\mathrm{U}_{\mathrm{i}}$, seperti truncated normal distributions atau two-parameter gamma distributions, pertimbangan terhadap data panel dan waktu dari variasi efisiensi teknis, perluasan dalam metodologi untuk fungsi biaya dan juga persamaan sistem estimasi, dan sebagainya. Tinjauan komprehensif tentang ini dapat ditemukan pada beberapa literatur, seperti Forsund et al. (1980), Schmidt (1986), Bauer (1990) dan Greene (1993).

Battese dan Coelli (1988) mengajukan fungsi produksi stochastic frontier untuk panel data (yang tidak seimbang) yang mempunyai pengaruh terhadap perusahaan yang diasumsikan didistribusikan sebagai truncated normal random variables, yang juga dimungkinkan bervariasi menurut waktu. Model tersebut sebagai berikut.

$$
Y_{i t}=X_{i t} \beta+\left(V_{i t}-U_{i t}\right), \quad \mathrm{i}=1, \ldots, \mathrm{N}, \quad \mathrm{t}=1, \ldots, \mathrm{T},
$$

Keterangan :

$\mathrm{Y}_{\mathrm{it}}=$ (logaritma dari) produksi perusahaan ke-i dan periode waktu ke-t;

$\mathrm{X}_{\mathrm{it}}=$ vektor $\mathrm{k} \times 1$ (transformasi dari) kuantitas input perusahaan ke-i dalam periode waktu ke-t;

$\beta=$ vektor dari parameter yang tidak diketahui;

$\mathrm{V}_{\mathrm{it}}=$ variabel random yang diasumsikan iid $\mathrm{N}\left(0, \sigma \mathrm{v}^{2}\right)$, dan independen dari $\mathrm{U}_{\mathrm{it}}=$ $\left(\mathrm{U}_{\mathrm{i}} \exp (-\eta(\mathrm{t}-\mathrm{T}))\right)$,

$\mathrm{U}_{\mathrm{i}}=$ variabel random yang diasumsikan disebabkan oleh inefisiensi teknis dalam produksi dan diasumsikan sebagai iid dan truncations at zero dari distribusi $\mathrm{N}\left(\mu, \sigma_{\mathrm{U}}^{2}\right)$; adalah parameter untuk diestimasi; dan the panel data tidak perlu komplit (misal, panel data tidak seimbang).

Selanjutnya digunakan parameter Battese dan Corra (1977) yang menggantikan $\sigma_{\mathrm{V}}^{2}$ dan $\sigma_{\mathrm{U}^{2}}^{2}$ dengan $\sigma^{2}=\sigma \mathrm{v}^{2}+\sigma_{\mathrm{U}}^{2}$ dan $\gamma=\sigma \mathrm{U}^{2} /\left(\sigma_{\mathrm{V}}^{2}+\sigma_{\mathrm{U}}^{2}\right)$. Ini dilakukan dengan perhitungan maximum likelihood estimates (MLE). Parameter, $\gamma$, harus berada antara 0 dan 1 , hal ini dimaksudkan untuk menyediakan nilai awal 
yang baik bagi penggunaan proses iterative maksimisasi seperti yang diusulkan oleh Davidon-Fletcher-Powell (DFP) algorithm. Fungsi log-likelihood model ini dipresentasikan dalam appendix tulisan Battese and Coelli (1992).

Pada setiap model statistik stochastic frontier, simpangan yang mewakili gangguan statistik (statistical noise) diasumsikan independen dan identik (iid) yang terdistribusi secara normal. Asumsi distribusi yang paling sering digunakan adalah setengah normal (half normal). Jika dua simpangan (vi dan ui) diasumsikan bersifat independen satu sama lain serta independen terhadap input produksi (xi), dan dipasang asumsi distribusi spesifik (secara berturut-turut : normal dan setengah normal), maka fungsi likelihood (maximum likelihood estimators) dapat dihitung. Metode estimasi lain yang dapat digunakan adalah melalui estimasi model dengan OLS (Ordinary Least Square) dan mengoreksi konstanta dengan menambahkan suatu penduga konsisten dari E(ui) berdasarkan momen yang lebih tinggi (dalam kasus setengah normal, digunakan momen ke dua dan ke tiga) dari residual kuadratik terkecil atau disebut CLOS (Corected Ordinary Least Square). Setelah model diestimasi, nilai-nilai (vi - ui) juga dapat diperoleh. Pada pengukuran efisiensi, penduga untuk uj juga diperlukan. Jondrow et al. (1982) menyarankan kemungkinan yang paling relevan adalah E(ui |vi - uj) yang dievaluasi berdasarkan nilai-nilai (vi - ui) dan parameter-parameternya. Jondrow et al. (1982) mengemukakan bahwa formula $\mathrm{E}(\mathrm{u} \mid \mathrm{v}-\mathrm{u})$ untuk kasus normal dan setengah normal. Struktur dasar model statistik stochastic frontier dapat diilustrasikan pada gambar 2.2.

Keunggulan pendekatan stocahstic frontier adalah dimasukkannya gangguan acak (disturbance term), kesalahan pengukuran dan kejutan eksogen yang berada di luar kontrol petani. Sementara itu, beberapa keterbatasan dari pendekatan ini adalah : (1) teknologi yang dianalisis harus diformulasikan oleh struktur yang cukup rumit, (2) distribusi dari simpangan satu sisi harus dispesifikasi sebelum mengestimasi model, (3) struktur tambahan harus dikenakan terhadap distribusi inefisiensi teknis, dan (4) sulit diterapkan untuk usahatani yang memiliki lebih dari satu output. 


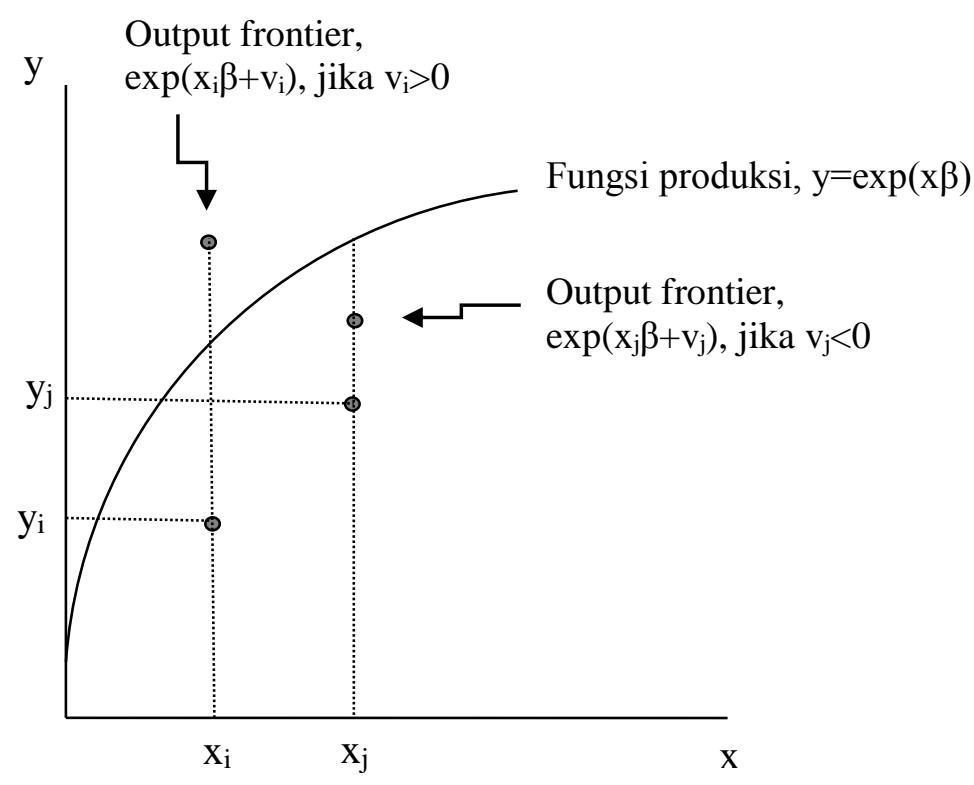

Gambar 2.2. Fungsi Produksi Stochastic Frontier (Sumber : Coelli et al. 1998)

Komponen nyata dari model frontier adalah $\mathrm{f}(\mathrm{xi} ; \beta)$ digambarkan dengan asumsi memiliki karakteristik skala pengembalian yang menurun (decreasing return to scale). Kegiatan produksi dari dua orang petani diwakili dengan simbol i dan j. Dalam hal ini, petani i dalam kegiatan usahataninya menggunakan input produksi sebesar xi dan memperoleh output sebesar yi. Output frontier petani i adalah yi*, melampaui nilai output dari fungsi produksi deterministik yaitu $f(x i ; \beta)$. Hal ini dapat terjadi karena kegiatan produksinya dipengaruhi oleh kondisi yang menguntungkan (misalnya curah hujan yang cukup, sinar matahari yang memadai, tidak adanya serangan organisme pengganggu tanaman/OPT), sehingga variabel vi bernilai positif. Sementara itu, petani j menggunakan input produksi sebesar $\mathrm{xj}$ dan memperoleh output sebesar yj, akan tetapi output frontier petani $\mathrm{j}$ adalah $\mathrm{yj}^{*}$ yang berada di bawah bagian yang pasti dari fungsi produksi. Hal ini dikarenakan kegiatan produksi dipengaruhi oleh kondisi yang kurang menguntungkan (misalnya; curah hujan terlalu tinggi, kekeringan, atau serangan OPT), yaitu vi bernilai negatif. Output frontier yang tidak dapat diobservasi ini berada di bawah output dari fungsi produksi determisnistik yaitu $\mathrm{f}(\mathrm{xi} ; \beta)$. Pada kasus kedua, hasil produksi yang dicapai petani $\mathrm{j}$ berada di bawah fungsi produksi frontier $\mathrm{f}(\mathrm{xi} ; \beta)$. 
Jondrow et al, (1982) kemudian mengukur tingkat efisiensi teknis (technical efficiency-TE) sebagai berikut.

$$
\begin{aligned}
& \mathrm{TE}=\exp (-\mathrm{E}[\mathrm{ui} / \varepsilon \mathrm{\varepsilon}]) \\
& \operatorname{dimana} \mathrm{E}\left[\mathrm{u}_{\mathrm{i}} / \varepsilon_{\mathrm{i}}\right]=\frac{\sigma_{\mathrm{u}} \sigma_{\mathrm{v}}}{\sigma}\left[\frac{\mathrm{f}\left(\varepsilon_{\mathrm{i}} \lambda / \sigma\right)}{1-\mathrm{F}\left(\varepsilon_{\mathrm{i}} \lambda / \sigma\right)}-\frac{\left(\varepsilon_{\mathrm{i}} \lambda\right)}{\sigma}\right]
\end{aligned}
$$

Keterangan;

$\lambda=\sigma_{\mathrm{u}} / \sigma_{\mathrm{v}}, \sigma^{2}=\sigma_{\mathrm{u}}^{2}+\sigma_{\mathrm{v}}^{2}$ sementara $\mathrm{f}$ dan $\mathrm{F}$ mewakili fungsi densitas standar normal dan fungsi distribusi standar normal masing-masing dievaluasi pada $\varepsilon i \lambda / \sigma$.

Efisiensi teknis usahatani tertentu didefinisikan berdasarkan rasio dari output yang diobservasi (Yi) dengan output frontiernya ( $\left.\mathrm{Yi}^{*}\right)$ menggunakan teknologi yang tersedia, berdasarkan dari hasil Persamaan (2.4) maka diperoleh;

$$
\mathrm{TE}=\frac{\mathrm{Y}_{\mathrm{i}}}{\mathrm{Y}_{\mathrm{i}}^{*}}=\frac{\mathrm{E}\left(\mathrm{Y}_{\mathrm{i}} \mid \mathrm{U}_{\mathrm{i}}, \mathrm{X}_{\mathrm{i}}\right)}{\mathrm{E}\left(\mathrm{Y}_{\mathrm{i}} \mid \mathrm{U}_{\mathrm{i}}=0, \mathrm{X}_{\mathrm{i}}\right)}=\mathrm{E}\left[\exp \left(-\mathrm{U}_{\mathrm{i}} \mid \varepsilon\right]\right.
$$

TE memiliki nilai-nilai mulai dari nol ke satu $\left(0 \leq \mathrm{TE}_{\mathrm{i}} \leq 1\right)$, dimana 1 menunjukkan suatu usahatani yang efisien secara penuh

Model estimasi fungsi biaya stochastic frontier usahatani pada tingkat efisiensi ekonomi secara keseluruhan ditentukan dengan :

$$
C_{i}=f\left(Y_{i}, P_{i} ; \alpha\right)+\varepsilon_{i} \quad i=1,2,3, \ldots n
$$

Keterangan:

$\mathrm{C}_{\mathrm{i}}=$ total biaya produksi,

$\mathrm{Y}_{\mathrm{i}}=$ output yang dihasilkan,

$\mathrm{P}_{\mathrm{i}}=$ harga input,

$\alpha=$ parameter biaya fungsi dan

$\varepsilon_{\mathrm{i}}=$ error term:

Namun, karena inefisiensi diasumsikan untuk selalu meningkatkan biaya, komponen kesalahan memiliki tanda-tanda positif (Coelli et al., 1998).

Efisiensi ekonomi usahatani tertentu (EE) didefinisikan sebagai rasio minimum yang diamati dari total biaya produksi $\left(\mathrm{C}^{*}\right)$ untuk biaya produksi aktual secara keseluruhan (C) dengan menggunakan hasil persamaan (2.6), diperoleh: 


$$
\mathrm{EE}=\frac{\mathrm{C}_{\mathrm{i}}}{\mathrm{C}_{\mathrm{i}}^{*}}=\frac{\mathrm{E}\left(\mathrm{C}_{\mathrm{i}} \mid \mathrm{U}_{\mathrm{i}}\right)=0, \mathrm{Y}_{\mathrm{i}} \mathrm{P}_{\mathrm{i}}}{\mathrm{E}\left(\mathrm{Y}_{\mathrm{i}} \mid \mathrm{U}_{\mathrm{i}}, \mathrm{Y}_{\mathrm{i}} \mathrm{P}_{\mathrm{i}}\right)}=\mathrm{E}\left[\exp \left(-\mathrm{U}_{\mathrm{i}} \mid \varepsilon\right)\right]
$$

Selanjutnya penentuan nilai EE berada antara 0 dan 1 . Oleh karena itu ukuran efisiensi alokatif (AE) pertanian secara spesifik diiperoleh dari efisiensi teknis dan ekonomi, yang dapat dihitung sebagai:

$$
\mathrm{AE}=\frac{\mathrm{EE}}{\mathrm{TE}}
$$

Dalam hal ini AE juga berarti berada pada $0 \leq \mathrm{AE} \leq 1$.

\subsection{Perilaku Terhadap Risiko}

Sektor pertanian dan usahatani menurut Widodo (2012) akan selalu mengalami instabilitas yang berdampak pada ketidakpastian dan risiko. Risiko dan ketidakpastian merupakan dua hal yang sangat mirip dan erat kaitannya satu sama lain. Selanjutnya (Kay, 1981; Debertin, 1986; Widodo, 2012) menyatakan bahwa secara umum risiko adalah suatu situasi dimana terdapat hasil akhir dan probabilitas yang dapat diketahui, sedangkan ketidakpastian adalah situasi dimana hasil akhir dan probabilitasnya tidak diketahui.

Istilah risiko lebih banyak digunakan dalam konteks pengambilan keputusan, karena risiko diartikan sebagai peluang akan terjadinya suatu kejadian yang tidak diinginkan akibat suatu tindakan. Makin tinggi tingkat ketidakpastian suatu kejadian, makin tinggi pula risiko yang disebabkan oleh pengambilan keputusan itu. Dengan demikian, identifikasi sumber risiko sangat penting dalam proses pengambilan keputusan. Nelson et al. (1978) menyatakan, faktor risiko di bidang pertanian berasal dari produksi, harga dan pasar, usaha dan finansial, teknologi, kerusakan, sosial dan hukum, serta manusia. Risiko hadir dalam semua keputusan pengelolaan sistem pertanian, sebagai akibat dari harga, hasil dan ketidakpastian sumber daya. Jika petani netral terhadap risiko, hal tersebut menjadi tidak relevan untuk mempertimbangkan risiko dalam proses pengambilan 
keputusan, karena tanggapan petani dapat diwakili oleh maksimalisasi keuntungan yang diharapkan.

Binswanger dan Siller (1983) menyatakan bahwa perbedaan inter personal terkait keengganan terhadap risiko (attitude toward risk) akan menyebabkan perbedaan dalam pengambilan keputusan di sektor pertanian. Sementara Dillon dan Scandizzo (1978) mengemukakan bahwa faktor-faktor sosial ekonomi yang terdapat pada petani dapat mempengaruhi sikap petani terhadap risiko.

Robinson dan Barry (1987) mengemukakan bahwa jika peluang suatu kejadian dapat diketahui oleh pembuat keputusan, yang didasarkan pada pengalaman maka hal tersebut menunjukkan konsep risiko. Selanjutnya dikatakan bahwa dalam menganalisis risiko didasarkan pada teori pengambilan keputusan dengan berdasarkan pada konsep kepuasan yang diharapkan (expected utility). Dalam kaitannya dengan expected utility sangat erat hubungannya dengan peluang (probability). Menurut Widodo (2012), pilihan tindakan yang akan diambil oleh seorang petani akan bergantung pada perilaku petaninya, petani kemungkinan akan memilih tindakan yang paling aman dengan risiko terkecil (minimizing risk) atau mungkin akan memaksimumkan harapan atau maximixing expected gain, dimana kedua perilaku ini akan menghasilkan pilihan yang berbeda.

Pendekatan yang umum dalam pemodelan hubungan teknologi dalam produksi berdasarkan pada tingkat rata-rata input dan output. Dalam formulasi ini masalah keputusan perusahaan/usahatani diselesaikan dengan menyamakan nilai marginal dari output untuk faktor biaya. Namun, secara luas diakui bahwa produk pertanian, terutama hasil panen, adalah stochastic (acak) dan tingkat input yang digunakan juga berpengaruh lebih tinggi (misalnya varians) dibandingkan distribusi output (De Janvry, 1972; Just dan Pope, 1979; dan Antle, 1983).

Sifat stochastic produksi pertanian merupakan sumber utama risiko. Dengan demikian, variabilitas terhadap hasil tidak hanya dijelaskan oleh faktor di luar kendali petani seperti input dan harga output tetapi juga oleh faktor-faktor 
terkendali seperti berbagai tingkat input (Just dan Pope, 1979; Antle, 1983). Keputusan produksi juga dipengaruhi oleh risiko pasar terkait dengan ketidakpastian tentang masa depan harga input dan output serta keandalan persediaan input (Hardaker et al. 1997). Meskipun risiko pasar pada dasarnya merupakan faktor eksogen, namun petani dapat mempengaruhi variabilitas hasil dan distribusi pengembalian dengan pilihan input dalam suatu usahatani tertentu atau kombinasi dari beberapa usahatani. Dengan demikian risiko produksi memiliki dampak yang luar biasa pada pertanian secara umum, dan pola produksi dan perilaku pasokan petani skala kecil pada khususnya.

Perilaku terhadap risiko dapat dibagi menjadi tiga jenis: 1) menghindari risiko, 2) memilih risiko dan 3) netral terhadap risiko (Bromley dan Chavas, 1989). Averters risiko atau avoiders ditandai dengan preferensi terhadap sumber risiko yang mengurangi pendapatan atau investasi, sedangkan individu yang lebih memilih risiko ditandai dengan preferensi terhadap usahatani yang lebih berisiko dan petani yang netral terhadap risiko adalah kasus dimana petani membatasi antara menghindari risiko dan lebih memilih risiko.

Petani akan memilih alternatif berdasarkan hasil tertinggi yang diharapkan, terlepas dari probabilitas terkait dengan potensi keuntungan atau kerugian. Cara mengelola risiko dan sejauh mana berbagai jenis risiko dikelola tergantung pada faktor-faktor seperti tingkat penghindaran risiko petani, biaya yang terlibat, ukuran relatif dari risiko, korelasi risiko dengan bentuk lain dari risiko, sumber ganti rugi lainnya, persepsi petani tentang sifat risiko, serta pendapatan petani dan keuntungan (Barry et al. 1995; Hardaker et al. 1997; Harington dan Niehaus, 1999).

Model risiko mula-mula dikembangkan oleh Just dan Pope (1979) yang digunakan untuk melihat risiko produksi pertanian. Fungsi produksi model Just dan Pope terdiri atas fungsi produksi rata-rata (mean production function) dan fungsi produksi varian (variance production function). Dalam model yang dikembangkan, fungsi produksi rata-rata maupun varian dipengaruhi oleh variabel 
input seperti lahan, benih, pupuk, pestisida, dan tenaga kerja, serta input-input lain. Selanjutnya diungkapkan bahwa beberapa input dapat menjadi faktor yang bersifat meningkatkan risiko produksi (risk inducing factors) dan faktor pengurang risiko produksi (risk reducing factors).

Beberapa peneliti (Just dan Pope, 1979; Bontems dan Thomas, 2000; Bokusheva dan Hockmann, 2005) menjelaskan bahwa dalam menganalisis sektor pertanian sangat penting untuk mempertimbangkan faktor risiko, khususnya risiko produksi. Apabila tidak memasukkan faktor risiko produksi akan membawa konsekuensi diperoleh kesimpulan yang tidak benar.

\section{Pengukuran Terhadap Risiko}

Just dan Pope (1979) mengembangkan model untuk mengatasi risiko produksi secara ekonometrika. Pendekatan tersebut cukup populer diantara para ilmuwan ekonomi pertanian dan masih saja digunakan pada kajian akhir-akhir ini (Tveteras, 1999,2000; Kumbhakar and Tsionas, 2002, dan sebagainya). Konsep dasar yang diperkenalkan oleh Just dan Pope membentuk fungsi produksi sebagai penjumlahan dari dua komponen yakni yang terkait dengan output dan yang terkait dengan variabilitas input. Hal ini menyebabkan ahli ekonometrika membedakan dampak input pada output dan risiko dan mampu mengakomodasikan risiko marjinal terhadap input. Menurut Just dan Pope, mengabaikan risiko produksi dapat menyebabkan penaksiran yang salah pada koefisien teknologi dan menghasilkan standard error yang keliru karena nilai yang lebih besar.

Kumbhakar (2002) sendiri menganggap model Just dan Pope secara umum memfokuskan pada risiko produksi, yang diukur dari varian output, dan menyarankan menggunakan spesifikasi fungsi produksi yang memenuhi beberapa properties yang dibutuhkan. Fokus utama dari spesifikasi Just dan Pope adalah alokasi input yang dapat menyebabkan kenaikan risiko atau penurunan risiko produksi. 
Ditinjau dari beberapa aspek kebijakan, informasi bahwa input tertentu itu dapat meningkatkan atau menurunkan risiko produksi merupakan hal yang cukup bermanfaat terutama dalam manajemen risiko produksi. Beberapa keterbatasan kerangka pemikiran Just dan Pope adalah: pertama, tidak memperhitungkan perilaku produsen dalam menghadapi risiko produksi. Perilaku produsen dalam menghadapi risiko produksi sangat berpengaruh dalam membuat keputusan alokasi penggunaan input dan pengaruhnya terhadap penawaran output. Dalam kenyataannya input-input maupun output-output adalah variabel pilihan sehingga sangat penting untuk membuat sebuah model yang tidak hanya mempertimbangkan risiko produksi tetapi juga mempertimbangkan perilaku produsen dalam menghadapi risiko produksi. Kedua, Just dan Pope (1979) menganggap bahwa error term dalam fungsi produksi adalah risiko produksi.

Just dan Pope mengacu pada metode Moscardi dan De Janvry (1977) sebelumnya. Monscardi dan De Janvry melakukan pengukuran terhadap risiko yang melibatkan tiga tahap, yang diawali dengan menaksir fungsi produksi. Metode ini memilih variabel yang paling nyata berpengaruh yang menentukan hasil dari hasil regresi $\mathrm{Y}^{*}$, dimana parameter variabel yang paling berpengaruh tersebut selanjutnya digunakan untuk menentukan tingkat perilaku petani dalam menghindari risiko berdasarkan pendekatan ekonometrika.

Berdasarkan pada pendekatan ekonometrik Moscardi dan De Janvry (1977), diasumsikan bahwa pendapatan bersih acak yang petani terima diperoleh dari ketidakpastian hasil dan diasumsikan juga dari hubungan antara input (X) dan output (Y) yang disajikan dalam fungsi produksi, koefisien variasi hasilnya adalah.

$$
\theta=\frac{\delta y}{\mu y}
$$

Keterangan; $\theta$ adalah koefisien variasi hasil, $\delta_{y}$ adalah deviasi standar dari hasil; $\mu_{y}$ adalah rata-rata hasil; dan harga faktor produksi $\left(\mathrm{P}_{\mathrm{i}}\right)$ dan harga produk $\left(\mathrm{P}_{\mathrm{y}}\right)$, maka pilihan dapat dimaksimumkan terhadap harga input. 
Hasil dari kondisi tingkat pertama adalah

$$
\mathrm{P}_{\mathrm{y}} \mathrm{f}_{\mathrm{i}} \frac{\mu y}{X i}=\frac{P i}{1-\theta K(s)}
$$

Keterangan: $\mathrm{P}_{\mathrm{i}}$ adalah harga input; $\mathrm{X}_{\mathrm{i}}$ adalah vektor input yang paling nyata; $\mathrm{P}_{\mathrm{y}}$ adalah harga output; $\mathrm{f}_{\mathrm{i}}$ adalah elastisitas produksi dari input ke-i; $\mathrm{K}_{(\mathrm{s})}$ adalah parameter menghindari risiko; sementara $\theta$ dan $\mu_{y}$ telah didefinisikan di persamaan (2.9).

Nilai parameter menghindari risiko diperoleh dari persamaan berikut.

$$
\mathrm{K}_{(\mathrm{s})}=\frac{1}{\theta}\left[1-\frac{P i \cdot X i}{P y \cdot f i \cdot \mu y}\right]
$$

Persamaan (3.1) menyediakan ukuran perilaku menghindari risiko $\mathrm{K}_{\mathrm{s}}$ dari masingmasing petani dari pengetahuan fungsi produksi, koefisien variasi hasil, harga produk dan faktor produksi dan tingkat penggunaan input.

Mengacu pada Moscardi dan De Janvry (1977), parameter menghindari risiko $\mathrm{K}_{(\mathrm{s})}$ digunakan untuk mengklasifikasikan petani menjadi 3 kelompok, yakni memilih risiko $\left(0<\mathrm{K}_{(\mathrm{s})}<0,4\right)$, netral terhadap risiko $\left(0,4 \leq \mathrm{K}_{\mathrm{s}} \leq 1,2\right)$ dan menghindari risiko $\left(1,2<\mathrm{K}_{(\mathrm{s})}<2,0\right)$.

\subsection{Konsep Daya Saing}

Istilah daya saing (competitiveness), berawal dari konsep keunggulan komparatif (comparative advantage) Ricardo sejak abad 18. Hukum keunggulan komparatif (The Law of Comparative Advantage) dari Ricardo menyatakan bahwa sekalipun suatu negara tidak memiliki keunggulan absolut dalam memproduksi dua jenis komoditas jika dibandingkan negara lain, namun perdagangan yang saling menguntungkan masih bisa berlangsung, selama rasio harga antar negara masih berbeda jika dibandingkan tidak ada perdagangan (Lindert dan Kindleberger, 1993). Ricardo menganggap keabsahan teori nilai berdasar tenaga kerja (labor theory of value) yang menyatakan bahwa hanya satu faktor produksi yang penting yang menentukan nilai suatu komoditas yaitu tenaga kerja. Nilai 
suatu komoditas adalah proporsional (secara langsung) dengan jumlah tenaga kerja yang diperlukan untuk menghasilkannya.

Menurut Boediono (1997), terdapat tiga faktor utama yang menentukan keunggulan komparatif suatu negara yaitu :

a. Tersedianya sarana produksi atau faktor produksi dengan jumlah dan macam yang berbeda antar negara satu dengan yang lain. Faktor produksi bisa berupa tenaga kerja, tanah (keadaan tanah dan kekayaan alam), barang modal dan kewirausahaan. Keunggulan komparatif akan lebih besar, jika suatu negara memiliki ketersediaan sarana produksi dalam jumlah yang relatif banyak.

b. Adanya kenyataan bahwa dalam cabang-cabang produksi tertentu bisa memproduksi secara lebih efisien apabila skala produksi makin besar (economic of scale). Kurva biaya per unit yang menurun dalam jangka panjang bisa menentukan keunggulan komparatif dan suatu negara bisa mencapai economic of scale jika berproduksi lebih dahulu daripada negara lain dan memiliki pasar domestik yang luas. Dari sisi pengekspor, pengusaha sudah memenuhi kebutuhan dalam negeri, maka untuk meningkatkan keuntungan membuka pasar baru, sedangkan dari segi pengimpor, akan membeli barang tersebut dengan harga yang murah, daripada memproduksi dengan skala kecil.

c. Adanya perbedaan dalam laju kemajuan teknologi. Teknologi adalah faktor produksi yang bisa mempengaruhi faktor produksi lain baik terhadap kualitas maupun kuantitas. Kemajuan teknologi dapat dibedakan menjadi penghematan kapital, tenaga kerja dan bahan mentah setiap menghasilkan satu unit output.

Namun pada perkembangannya kemudian, teori-teori perdagangan yang sebelumnya mengandalkan keunggulan komparatif sudah mulai bergeser sejalan dengan perkembangan globalisas ekonomi, sehingga muncullah suatu konsep dalam perdagangan yang disebut sebagai competitive advantage of nation (Porter, 1993). Konsep keunggulan kompetitif adalah suatu cara yang dilakukan oleh perusahaan untuk memperkuat posisinya dalam menghadapi pesaing dan mampu menunjukkan perbedaan-perbedaan dengan lainnya. Tujuan atas aspek perubahan 
fundamental yang dibuat Porter sekaligus membedakan rumusan teorinya dari kelimpahan faktor-faktor endowment adalah terletak pada faktor-faktor produksi yang dimiliki ada yang sifatnya dasar (basic factor) seperti daya fisik yang belum terolah atau tenaga kerja non-trampil, dan faktor-faktor produksi lanjutan (advance factors) yang merupakan aneka faktor produksi canggih misalnya peralatan model, tenaga kerja yang mempunyai kecakapan pengetahuan serta keterampilan tinggi, sumber-sumber daya pengetahuan serta institut riset yang diperoleh dari lembaga ilmiah, swasta serta sumber daya institusional seperti asosiasi bisnis yang tangguh.

Model berbasis sumberdaya dapat diimplementasikan apabila suatu perusahaan memiliki sesuatu yang khas sehingga berbeda dari perusahaan lain dan bisa dijadikan suatu keunggulan dibandingkan dengan pesaing. Dengan adanya sumberdaya yang khas, maka perusahaan dapat meminimalisasi biaya sehingga menciptakan harga yang bersaing.

Harga yang digunakan untuk mengukur keunggulan kompetitif adalah harga yang aktual diterima oleh konsumen maupun produsen. Dikarenakan asumsi perekonomian yang tidak mengalami distorsi sulit ditemukan, maka keunggulan komparatif tidak bisa dijadikan sebagai indikator daya saing, tetapi harus diimbangi dengan kelayakan finansial untuk mengukur keunggulan kompetitif.

Menurut Gittinger (2008), perhitungan dalam analisis finansial berbeda dengan analisis ekonomi berdasarkan lima hal yaitu :

a. Dalam analisis finansial, harga yang digunakan adalah harga pasar baik untuk sumber-sumber yang digunakan dalam proses produksi maupun untuk hasilhasil produksi. Sedangkan dalam analisis ekonomi digunakan harga bayangan yaitu harga yang telah disesuaikan untuk menggambarkan nilai ekonomi yang sebenarnya dari barang dan jasa tersebut.

b. Dalam analisis finansial pajak dihitung sebagai biaya yang dikeluarkan kepada instansi pemerintah sehingga harus dikurangkan dari benefit. Sebaliknya dalam analisis ekonomi pajak merupakan pembayaran transfer 
karena merupakan bagian dari benefit produsen yang diserahkan kepada pemerintah.

c. Dalam analisis finansial, subsidi yaitu pengurangan biaya produksi yang diterima produsen, sedangkan dalam analisis ekonomi dianggap sebagai beban masyarakat sehingga tidak mengurangi biaya produksi.

d. Dalam analisis finansial, biaya investasi meliputi biaya pada tahap permulaan yang dibiayai dengan modal sendiri. Di lain pihak, yang menjadi beban produsen adalah arus pelunasan pinjaman beserta bunganya pada tahap produksi. Sedangkan dalam analisis ekonomi, seluruh biaya investasi baik berasal dari dalam maupun pinjaman. Pelunasan pinjaman diabaikan dalam perhitungan biaya ekonomi.

e. Dalam analisis finansial, bunga atas pinjaman dianggap sebagai biaya. Bunga atas modal sendiri bukan merupakan biaya. Sedangkan dalam analisis ekonomi, dari pemerintah untuk kebutuhan petani. Kebijakan yang dijalankan pemerintah bisa terhadap input tradable dan non tradable berupa intervensi pemerintah dalam bentuk subsidi dan pajak.

Selanjutnya teori Heckscher-Ohlin menyatakan bahwa komoditaskomoditas yang dalam produksinya memerlukan faktor produksi (yang melimpah) dan (yang langka) di ekspor untuk ditukar dengan barang-barang yang membutuhkan faktor produksi dalam proporsi yang sebaliknya. Jadi secara tidak langsung faktor produksi yang melimpah diekspor dan faktor produksi yang langka diimpor (Ohlin dalam Lindert dan Kindleberger, 1993).

Hal ini kemudian diuji oleh Leontief (1953) dalam (Lindert and Kindleberger, 1993) yang menghasilkan "The Leontief Paradox". Hasil kajian Leontief menunjukkan bahwa AS mengekspor barang- yang padat tenaga kerja ke bagian dunia lainnya dan mengimpor barang-barang yang relatif padat modal dan tenaga kerja. Baru kemudian terjawab adanya keunggulan pembelajaran (learning advantage) Yang meliputi pendidikan dan pelatihan, pengalaman (termasuk kearifan tradisional), serta penelitian dan pengembangan (inovasi teknologi). 


\section{Pengukuran Status Daya Saing}

Pengukuran status daya saing sektor agribisnis dapat menggunakan Relative Trade Advantage/RTA (Balasa, 1989). Sedangkan analisis status daya saing terutama dari executive opinion dapat dilakukan dengan Agribusiness Executive Survey (AES). Sementara itu, untuk analisis kualitatif dan kuantitatif pada level kelembagaan agribisnis dapat menggunakan Agribusiness Confidence Index (ACI). Alat ukur daya saing yang juga banyak digunakan adalah Revealed Competitive Advantage (RCA). Belakangan ini, dengan menggunakan Policy Analysis Matrix (PAM) akan dihasilkan dua indikator pokok pengukur daya saing, yaitu Private Cost Ratio (PCR) yang merupakan indikator keunggulan kompetitif yang menunjukkan kemampuan sistem untuk membayar biaya sumber daya domestik dan tetap kompetitif pada harga privat dan Domestic Resource Cost Ratio (DRC) merupakan indikator keunggulan komparatif, yang menunjukkan jumlah sumberdaya domestik yang dapat dihemat untuk menghasilkan satu unit devisa (Monke and Pearson, 1995).

Kelebihan model PAM ini adalah selain diperoleh koefisien DRC (Domestic Resource Cost Ratio) sebagai indikator keunggulan komparatif, analisis ini juga dapat menghasilkan beberapa indikator lain yang berkait dengan variabel daya saing, seperti PCR (Private Cost Ratio) untuk menilai keunggulan kompetitif, NPCO (Nominal Protection Coefficient on tradable Output), NPCI (Nominal Protection Coefficient on tradable Inputs), EPC (Effective Protection Coefficient), PC (Profitability Coefficient), dan SRP (Subsidy Ratio to Producers). Untuk mendapatkan nilai-nilai koefisien tersebut, setiap unit biaya (input), output, dan keuntungan dikelompokkan ke dalam harga pasar (privat) dan harga sosial.

Efisiensi berhubungan dengan pencapaian output maksimum dari penggunaan sumber daya tertentu. Jika output dihasilkan lebih besar dibandingkan dengan input yang digunakan berarti tingkat efisiensi lebih tinggi. Debertin (1986) mengemukakan efisiensi dapat dilihat dari dua aspek yaitu (1) aspek teknis dan (2) aspek ekonomi. Efisien tidaknya suatu produksi barang atau jasa dalam 
perdagangan internasional dapat ditentukan dengan menggunakan biaya unit sumber daya domestik atau Domestic Resource Cost (DRC). Lebih lanjut dikatakan bahwa efisien tidaknya produksi jenis barang dan jasa dapat dipergunakan (tradable) tergantung pada daya bersaingnya di pasar dunia, artinya sejauhmana penggunaan biaya terhadap pemakaian sumber-sumber domestik terutama tenaga kerja dan modal cukup rendah, sehingga harga jualnya tidak akan melebihi harga jual yang relevan, serta dinyatakan dalam dollar dengan harga bayangan (shadow price) dari devisa.

Unit biaya sumber daya domestik (domestic resource cost) dapat digunakan untuk mengukur social opportunity cost dari faktor-faktor produksi domestik yang digunakan secara langsung dan tidak langsung dalam aktivitas produksi dari penerimaan tiap unit tambahan bersih devisa. Tower (1992) mengemukakan bahwa dengan pendekatan Domestic Resource Cost (DRC) sangat baik digunakan untuk mengukur aktivitas suatu kegiatan ekonomi dan menaksir harga bayangan input.

Selanjutnya Pearson (1987) mengemukakan beberapa asumsi yang digunakan dalam menganalisis Domestic Resource Cost, yaitu :

1. Pemerintah tidak melakukan intervensi campur tangan pada nilai tukar uang dan perdagangan komoditas yang dianalisis (dalam bentuk peraturan-peraturan atau pembatasan-pembatasan). Biaya produksi dari tambahan satu satuan output ditentukan oleh hubungan input output yang konstan dan harga relatif faktor-faktor produksi tidak mengalami perubahan.

2. Shadow price faktor-faktor produksi dan output dapat dihitung dan mewakili social opportunity cost yang sesungguhnya.

3. Output yang dianalisis bersifat tradable.

Menurut Tower (1991), pendekatan ini sangat bagus untuk menghitung biaya dan manfaat sosial bersih pada suatu sektor dan nilai tambah yang diharapkan dari harga bayangan (shadow price) di dalam melakukan pertukaran. 
Selanjutnya dengan pendekatan ini sekaligus dapat mengukur manfaat yang diperoleh dari efisiensi yang dilakukan dalam aktivitas ekonomi suatu daerah.

Berdasarkan uraian di atas maka strategi yang ditempuh untuk mengetahui apakah komoditas berbasis sumberdaya alam mempunyai daya saing berkelanjutan atau tidak, pertama-tama harus diketahui bagaimana posisi komoditas tersebut di pasar bersangkutan, dan bagaimana kemungkinan prospeknya. 


\section{PENGEMBANGAN KAPAS DAN METODE ESTIMASI}

\subsection{Kapas di Sulawesi Selatan}

Pengembangan kapas di Sulawesi Selatan di mulai sejak tahun 1973. Dalam perjalanannya hingga saat ini mengalami pasang-surut yang cukup tajam berkaitan dengan areal tanam, produksi, produktivitas, dan pengelolaannya. Pengembangan kapas di Sulawesi Selatan pada awalnya diusahakan, melalui Perusahaan Umum Perkebunan Kapas Rakyat (PUPKI). Usaha perkebunan tersebut tidak berkembang karena dikelola melalui swadaya petani, tidak ada jaminan pembelian hasil karena PUPKI tidak mempunyai dana dan kapas biji yang dihasilkan oleh petani harus diolah di Jawa Timur karena tidak tersedia ginnery di Sulawesi Selatan.

Pada periode selanjutnya (1978-1990) usahatani kapas diterapkan dengan pola Intensifikasi Kapas Rakyat (IKR). Direktorat Jenderal Perkebunan menunjuk PTP XXIII sebagai perusahaan pengelola, serta menyiapkan dana pengadaan sarana produksi melalui perbankan (Bank EXIM) sebagai skim kredit KMKP dan PTP XXIII sebagai penjamin kredit petani. Dalam perjalanannya, periode IKR ini mengalami perubahan dalam pola penanganannya sebanyak dua kali, sehingga dalam kurun waktu tersebut terdapat tiga pola pengelolaan, ykani : a) penanganan langsung oleh Ditjen Perkebunan (1978 - 1982), b) pola BIMAS (1983 - 1986), hingga c) penanganan kapas dikembalikan ke Ditjen Perkebunan (1987 - 1990). Pada akhir masa ini (1990), pemerintah memberlakukan Paket Januari (Pakjan) 90, yang sangat memperketat pengaturan penyaluran kredit, sehingga banyak petani kapas yang masih memiliki tunggakan tidak dapat memperoleh kredit, yang mengakibatkan penurunan areal secara drastis menjadi lebih kurang $2.990 \mathrm{Ha}$. 
Pada awal tahun 1991, pengembangan kapas dilakukan melalui pola Pengembangan Perkebunan Wilayah Khusus (P2WK), yang merupakan program Ditjen Perkebunan untuk meningkatkan pendapatan masyarakat pada wilayahwilayah yang terpencil. Pada periode ini, dana pengadaan saprodi pada tahun pertama berasal dari APBN, yang selanjutnya akan digulirkan kembali melalui Simpeda pada BPD Sulsel atas nama setiap kelompok tani. Melalui pola ini, areal tanam dapat ditingkatkan kembali menjadi lebih dari 19.800 ha pada tahun 1993, dengan tingkat produktivitas yang juga sedikit meningkat yaitu sekitar $500-700$ $\mathrm{kg} / \mathrm{ha}$. Pada masa-masa akhir periode ini telah mulai dimasukkan perusahaan pengelola swasta selain PTP XXIII.

Periode Kemitraan berlangsung sejak tahun 1994 hingga 2000, Periode ini ditandai dengan ditunjuknya beberapa perusahaan tekstil sebagai pengelola kapas menggantikan PTP XXIII dengan menerapkan pola kemitraan antara perusahaan-perusahaan tersebut dengan petani. Dengan demikian, pendanaan kapas tidak semata berasal dari pemerintah, tetapi juga swadana pengelola serta kredit perbankan (KKPA).

Pada periode ini petani semakin bergantung pada insektisida akibat tingginya tingkat serangan hama. Selain itu, permasalahan baru juga timbul yiatu semakin terbatasnya benih bermutu akibat tidak adanya perlakuan khusus terhadap benih oleh setiap pengelola. Hal ini menyebabkan produktivitas semakin sulit untuk ditingkatkan, dan bertahan pada kisaran $500 \mathrm{~kg} / \mathrm{ha}$. Untuk mengatasi permasalahan tersebut, pada masa ini telah mulai dilakukan peningkatan kualitas SDM melalui Sekolah Lapang Pengendalian Hama Terpadu (SL-PHT) serta melengkapi petugas dengan sarana yang memadai, namun hingga akhir tahun 2000, belum nampak gejala yang mengarah pada peningkatan produktivitas.

Selanjutnya berdasarkan Keputusan Menteri Pertanian (Kepmen) No. 107/Kpts/KB.430/II/2001 yang dilanjutkan Kepmen No. 03/Kpts/KB.430/I/2002 tentang pelepasan secara terbatas kapas transgenik, dilakukan pengembangan kapas untuk 7 (tujuh) kabupaten (Bantaeng, Bulukumba, Gowa, Takalar, Bone, 
Soppeng dan Wajo). Hasil penelitian tahun 2001, di salah satu kabupaten lokasi pengembangan (Kabupaten Wajo) diperoleh produksi sebesar $1.121 \mathrm{~kg} / \mathrm{ha}$ (Thamrin, 2007). Sementara hasil penelitian Kabupaten Bulukumba, Bantaeng dan Gowa menunjukkan rata-rata produksi sebesar $2.183 \mathrm{~kg} / \mathrm{ha}$ (Ibrahim, 2008). Kegiatan ini akhirnya terhenti karena besarnya tuntutan pemerhati lingkungan berkaitan dampak komoditi transgenik yang belum memiliki kepastian keamanan terhadap lingkungan.

Perkembangan selanjutnya, pola kemitraan ini terus didorong oleh pemerintah dan mulai tahun 2007 dikemas dalam bentuk Program Akselerasi Pengembangan Kapas. Sejak saat itu, Indonesia telah menjalin kerja sama dengan Republik Rakyat Cina (RRC) untuk mengembangkan benih kapas hibrida di tujuh provinsi. Kerja sama tersebut yakni Indonesia mengimpor sebanyak 40 ton benih kapas dari Hubei Provincial Seed Group, RRC yang akan ditanam di Sulawesi Selatan, Jawa Timur, Jawa Tengah, DIY, Bali, NTT dan NTB masing masing setiap provinsi seluas 10 hektar sebagai uji coba (Sinar Tani, 2008).

Fasilitasi pemerintah dalam kegiatan akselerasi pengembangan kapas, difokuskan pada kegiatan yang meliputi subsidi bantuan input berupa benih kapas $(100 \%)$ sesuai standar kebutuhan teknis lapangan dan sebagian sarana produksi (25\%). Diharapkan kekurangan dari bantuan pupuk akan dipenuhi dari swadaya petani. Adapun dosis pupuk per hektar untuk pengembangan kapas terdiri dari Urea 100 kg, ZA 50 kg, SP-36 100 kg dan KCl 100 kg (Ditjenbun, 2012).

Pemerintah juga menetapkan kebijakan harga pembelian kapas berbiji di tingkat petani. Dalam upaya terus meningkatkan pendapatan petani, harga kapas berbiji ditingkat petani perlu dihitung dengan mempertimbangkan; a) harga serat kapas dipasar internasional yang cenderung terus meningkat pasca penghapusan subsidi ekspor kapas negara maju; b) biaya operasional perusahaan pengelola antara lain : pembelian kapas berbiji, sewa biaya ginning, operasional lapangan, dan biaya manajemen; c) analisis biaya usaha tani kapas, dan inflasi. Disamping itu perlu dipertimbangkan "harga psikologis" ditingkat petani, yaitu kenaikan 
harga walaupun nilainya kecil tetapi dapat meningkatkan motivasi petani dalam mengembangkan tanaman kapas sedangkan dari sisi perusahaan pengelola tidak berpengaruh secara nyata. Berdasarkan pertimbangan tersebut diatas, harga kapas berbiji ditingkat petani tahun 2010 sebesar Rp. 4.050,- per kg (Ditjenbun, 2009).

\subsection{Pengukuran Efisiensi Produksi Komoditas Petanian}

Selama ini Indonesia dihadapkan pada kondisi bahwa komoditas perkebunan mempunyai tingkat produktivitas yang rendah dengan tingkat efisiensi yang rendah. Secara empiris, petani tidak selalu dapat mencapai tingkat efisiensi yang tinggi. Hal ini disebabkan karena produksi yang diperoleh merupakan resultante dari pengaruh faktor-faktor yang sifatnya eksternal (tidak dapat dikendalikan oleh petani) dan faktor-faktor yang sifatnya internal (dapat dikendalikan oleh petani, sehingga karenanya dapat diperbaiki). Menurut Sumaryanto (2001) secara garis besar, proses produksi tidak efisien karena dua hal tersebut, utamanya karena secara teknis tidak efisien. Ini terjadi karena ketidakberhasilan mewujudkan produktivitas maksimal, artinya permintaan paket masukan dan keluaran tertentu atau proporsi penerimaan marjinal (marginal revenue product) tidak sama dengan biaya marjinal (marginal cost) masukan yang digunakan.

Efisiensi dapat digunakan sebagai ukuran sejauh mana sistem produksi tersebut telah menerapkan prinsip ekonomi, yaitu bagaimana menghasilkan tingkat keluaran tertentu dengan menggunakan masukan seminimal mungkin atau bagaimana menghasilkan produk semaksimal mungkin dengan menggunakan sejumlah masukan tertentu. Farrell (1957) mengemukakan bahwa efisiensi sebuah perusahaan terdiri dari dua komponen: efisiensi teknis, yang mencerminkan kemampuan perusahaan untuk memperoleh output maksimum berdasarkan penggunaan sejumlah input tertentu, dan efisiensi alokatif, yang merefleksikan kemampuan dari perusahaan untuk menggunakan input dengan proporsi yang optimal pada masing-masing tingkat harga input dan output serta teknologi yang 
tersedia. Kedua ukuran efisiensi ini kemudian digabung untuk menghasilkan ukuran total efisiensi ekonomi.

Estimasi efisiensi produksi telah menjadi penelitian penting di negaranegara maju dan berkembang. Terutama bagi negara-negara berkembang, di mana potensi untuk meningkatkan produksi pertanian melalui peningkatan dan pengembangan kegiatan budidaya serta adopsi teknologi baru sangat terbatas. Penelitian berkaitan hal tersebut dapat membantu negara-negara berkembang dalam menentukan sejauh mana kemungkinan meningkatkan produksi dengan meningkatkan efisiensi di tingkat petani, dengan basis sumber daya dan teknologi yang ada (Kibaara, 2005). Terdapat sejumlah studi empiris untuk mengukur efisiensi di bidang pertanian yang telah dilakukan selama ini, termasuk di Indonesia, namun di Indonesia kajian empiris tentang efisiensi produksi kapas memang masih sangat terbatas.

Kajian tentang efisiensi kapas yang dapat ditelusuri adalah hasil penelitian Syam (2004) yang memaparkan hasil estimasi fungsi produksi stochastic frontier pada usahatani kapas transgenik di Sulawesi Selatan yang menunjukkan bahwa input produksi pupuk; baik itu pupuk Urea, TSP, $\mathrm{KCl}$, maupun ZA, sangat nyata mempengaruhi produksi kapas. Varietas kapas juga sangat mempengaruhi produksi kapas, kondisi ini menunjukkan bahwa petani kapas telah menemukan alternatif baru untuk terobosan teknologi yang meningkatkan produktivitas secara nyata. Selanjutnya jika diukur dari rataan tingkat efisiensi teknis (technical efficiency_TE) terhadap 120 petani sampel kapas diperoleh nilai sebesar 0,71, dengan sebaran TE terbanyak pada TE 0,600,70 dan 0,90 . Ini menunjukkan bahwa masih ada peluang untuk meningkatkan produktivitas tanaman kapas di daerah atau petani yang tingkat efisiensinya masih di atas 0,60 dan di bawah 0,90.

Penelitian lainnya dilakukan di daerah penghasil kapas di Pakistan seperti yang dilakukan Battese dan Hassan (1999), Hussain (1999) dan penelitian Bravo- 
Ureta dan Evenson (1994) di Paraguay. Penelitian ini secara bersama-sama berfokus pada efisiensi teknis dan inefisiensi produksi tanaman kapas.

Battese dan Hassan (1999) mengestimasi tingkat efisiensi teknis budidaya tanaman kapas di daerah Vehari Punjab dengan menggunakan model fungsi produksi stochastic frontier kaitannya dengan pengaruh inefisiensi teknis yang diasumsikan sebagai fungsi dari variabel pengamatan yang berhubungan dengan kegiatan pertanian. Penelitian ini menyimpulkan bahwa inefisiensi teknis produksi kapas cenderung menurun akibat aktivitas usahatani, utamanya pengairan pada tanaman, namun kecenderungannya meningkat pada sebagian besar kegiatan budidaya lainnya. Pada saat yang sama Hussain (1999) mengukur efisiensi teknis, alokatif dan efisiensi ekonomi usahatani kapas, terhadap petani di empat daerah di Provinsi Punjab Pakistan dengan menerapkan pendekatan SFA dan DEA. Nilai efisiensi yang diperoleh menggunakan pendekatan DEA masingmasing 0,60, 0,70 dan 0,49, sedangkan dengan pendekatan SFA masing-masing nilai efisiensinya sebesar $0,65,0,74$ dan 0,49 . Penelitian ini juga menyimpulkan bahwa inefisiensi produksi kapas cenderung menurun sebagai akibat perbedaan tingkat pendidikan petani, penyuluhan pertanian dan adanya fasilitas kredit, tetapi cenderung meningkat karena adanya pengaruh umur petani.

Bravo-Ureta dan Evenson (1994) melakukan pendugaan efisiensi teknis, alokatif dan ekonomi terhadap petani di Paraguay Timur berdasarkan penggunaan teknologi. Penelitian ini menggunakan fungsi produksi froentir Cobb-Douglas yang mengestimasi 87 petani kapas dan 101 petani singkong. Rata-rata efisiensi teknis, alokatif dan ekonomi masing-masing adalah 58, 70 dan 41\% untuk petani kapas. Sedangakan rata-rata efisiensi teknis, alokatif, dan ekonomi petani singkong masing-masing adalah 59, 89 dan 52\%. Analisis dilakukan dengan menghubungan antara efisiensi dan lima variabel sosial ekonomi (umur, luas lahan, pengalaman, pendidikan, penyuluhan dan pemanfaatan kredit) dan menemukan hubungan yang sangat lemah antara efisiensi dan karakter sosialekonomi yang dimaksud. 
Penelitian lainnya berkaitan dengan efisiensi ekonomi pada usahatani kapas organik di Viotia, Yunani oleh Tzouveleka et al. (2001) yang hasil penelitiannya menunjukkan bahwa tipe pertanian organik dan konvensional, inefisien secara teknis, alokatif dan ekonomi. Umur petani, pendidikan, luas lahan merupakan faktor yang mempengaruhi efisiensi. Pertanian organik menunjukkan nilai efisiensi yang lebih rendah dibanding pertanian konvensional dalam hal efisiensi teknis dan ekonomi, sedangkan efisiensi alokatif keduanya hampir sama, yakni keduanya inefisien. Penelitian ini menyimpulkan bahwa nilai efisiensi yang rendah kemungkinan merupakan dampak intervensi kebijakan 20 tahun yang lalu.

Gull et al. (2009) juga mengemukakan hasil penelitiannya yang menganalisis efisiensi teknis usahatani kapas yang dilakukan di daerah Çukurova, Turki, menggunakan Data Envelopment Analysis (DEA). Penelitian ini menunjukkan bahwa rata-rata efisiensi teknis petani kapas di daerah tersebut sebesar $79 \%$. Dampak terbesar berasal dari penggunaan pupuk phosfor, tenaga kerja, penggunaan benih dan penambahan irigasi. Inefisiensi menunjukkan adanya suatu penggunaan yang kurang baik dimana hasil pengamatan menunjukkan adanya kelebihan pengunaan sodium dan kekurangan kalium. Dengan demikian, produsen harus dididik tentang penggunaan pupuk, dan berdasarkan hasil analisis juga menunjukkan bahwa yang mempengaruhi tingkat efisiensi adalah usia petani, tingkat pendidikan dan kelompok tani yang berada di wilayah pengembangan kapas.

Nilai efisiensi usahatani kapas menggunakan dua pendekatan yang berbeda, SFA dan DEA juga dilaporkan Chakraborty et al. (2002) yang menghitung efisiensi petani kapas berdasarkan pendekatan fungsi produksi stochastic dan non stochastic. Nilai efisiensi rata-rata tidak berbeda pada kedua metode pengukuran tersebut dengan asumsi constant to scale. Secara rata-rata, usahatani dengan irigasi memiliki tingkat efisiensi $80 \%$ dan non irigasi efisiensinya $70 \%$. Temuan penelitian ini menunjukkan bahwa di Texas, irigasi pertanian, secara rata-rata dapat mengurangi pengeluaran input lainnya sebesar 
$10 \%$ dan pertanian non irigasi mengurangi pengeluaran mesin dan tenaga kerja sebesar 12 dan $13 \%$ dan menghasilkan tingkat output yang sama.

Hasil penelitian Javed et al. (2011) terhadap sistem usahatani kapas dan gandum menunjukkan bahwa keuntungan sebagai akibat dari peningkatan efisiensi produksi dapat diperoleh pada semua kategori ukuran usahatani (skala usaha). Pembagian efisiensi teknis total ke dalam efisiensi teknis dan skala efsiensi lainnya mengungkapkan bahwa usahatani skala kecil lebih efisien secara teknis $(0,83)$ daripada usahatani skala besar $(0,80)$ dan menengah $(0,83)$. Tingkat efisiensi teknis total yang tinggi yang diperoleh pada usahatani besar $(0,94)$ terutama terhadap skala efisiensi. Usahatani kecil secara alokatif kurang efisien dibanding dengan usahatani skala menengah dan besar, meskipun keuntungan yang diakibatkan oleh peningkatan efisiensi alokatif terjadi pada $96 \%$ sampel usahatani.

Hasil penelitian terkait efisiensi pada tanaman lainnya, misalnya usahatani jagung di lahan kering di Kalimantan Selatan oleh Kurniawan et al. (2008) melaporkan bahwa luas lahan, benih, pupuk organik, pupuk P, pestisida, tenaga kerja dan pengolahan tanah berpengaruh nyata terhadap produksi jagung pada taraf $\alpha=15 \%$, sedangkan pupuk $\mathrm{N}$ dan $\mathrm{K}$ tidak berpengaruh nyata. Sementara faktor-faktor umur, pendidikan, pengalaman dan keanggotaan dalam kelompok tani tidak berpengaruh nyata terhadap inefisiensi teknis.

Akinbode et al. (2011) yang mengestimasi efisiensi teknis, alokatif dan ekonomi di Nigeria menyimpulkan bahwa mayoritas (60\%) petani di Ofada memiliki hubungan dengan para penyuluh sementara $56 \%$ petani tidak memiliki akses untuk mendapatkan kredit. Ketersediaan inovasi baru, modal dan ketidaktersediaan traktor adalah masalah yang paling mencolok dihadapi usaha tani padi di Ofada. Rata-rata efisiensi teknis, efisiensi alokatif dan ekonomi masing-masing sebesar 0,73,0,93 dan 0,67. Penelitian ini menyimpulkan bahwa petani padi masih dapat meningkatkan output atau menghemat biaya tanpa perlu 
mengubah teknologi yang sudah ada. Selain itu, hubungan dengan penyuluh dan pendidikan petani sangat berperan dalam pencapaian efisiensi produksi padi.

Nwaru et al. (2011), mengkaji tentang pengukuran dan faktor penentu efisiensi produksi petani sweet potato di Imo, Negeria. Hasil penelitian menunjukkan bahwa tingkat efisiensi alokatif pertanian petani sweet potato sekitar $77 \%$. Ukuran rumah tangga, akses mendapatkan kredit, keanggotaan koperasi dan pengalaman berusahatani secara positif dan signifikan berpengaruh terhadap efisiensi alokatif. Koefisien untuk ukuran usahatani dan gender berpengaruh negatif, yang menunjukkan bahwa petani wanita lebih efisien secara alokatif daripada petani pria.

Sumber efisiensi teknis petani penggarap jagung dan petani kacang tanah di wilayah pertanian Slash dan Burn, Kamerun dikemukakan oleh Binam et al. (2005) yang mengungkapkan ukuran efisiensi teknis dari 450 petani di wilayah Slash dan Burn di Kamerun. Fungsi produksi stochastic frontier digunakan untuk menghitung tingkat efisiensi teknis petani. Hasil analisis mengungkapkan bahwa tingkat rata-rata efisiensi teknis sama dengan 78, 80 dan 77, masing-masing untuk monokultur kacang tanah, monokultur jagung dan sistem tumpangsari jagung dan kacang tanah. Hasil penelitian yang dilakukan juga menunjukkan bahwa keuntungan substansial terhadap output dan/atau penurunan biaya dapat dicapai dengan meningkatkan perlakuan teknis. Berkaitan hubungan antara efisensi teknis dan berbagai karakteristik petani, hasil penelitian menunjukkan bahwa pendidikan dan keanggotaan dalam kelompok tani merupakan variabel yang paling berpengaruh. Hasil analisis menunjukkan bahwa pembuat kebijakan harus mendorong perkembangan kelompok tani formal atau asosiasi petani dengan meningkatkan kapasitas petani terhadap penemuan teknologi dan keterampilan manajemen. 
Tabel 3.1. Review Penelitian Tentang Efisiensi Komoditas Pertanian

\begin{tabular}{|c|c|c|c|}
\hline No. & Judul Penelitian & Variabel/pengamatan & Teknik Analisis \\
\hline 1 & $\begin{array}{l}\text { Analisis Efisiensi Produksi Komoditas } \\
\text { Kapas di Sulawesi Selatan [Syam, } \\
\text { 2004] }\end{array}$ & $\begin{array}{l}\text { Umur, tanggungan keluarga, } \\
\text { pendidikan, luas UT, pola } \\
\text { tanam, cara tanam, } \\
\text { pemupukan,. Pestisida }\end{array}$ & $\begin{array}{lr}\text { Stochastic } & \text { frontier } \\
\text { analysis } & \text { (SFA) } \\
\text { mengggunakan } & \\
\text { Model Cobb-Douglass }\end{array}$ \\
\hline 2 & $\begin{array}{l}\text { Technical efficiency of cotton farmers } \\
\text { in the Vehari District of Punjab, } \\
\text { Pakistan [Battese and Hassan, 1999] }\end{array}$ & Kegiatan budidaya & $\begin{array}{l}\text { Stochastic frontier } \\
\text { analysis }(S F A)\end{array}$ \\
\hline 3 & $\begin{array}{l}\text { An analysis of the efficiency of cotton } \\
\text { farmers in the Punjab Province in } \\
\text { Pakistan[Hussain, 1999] }\end{array}$ & $\begin{array}{l}\text { Umur petani pendidikan } \\
\text { petani, penyuluhan per- } \\
\text { tanian, fasilitas kredit, }\end{array}$ & $\begin{array}{l}\text { SFA dan DEA (Data } \\
\text { Envelopment Analysis) }\end{array}$ \\
\hline 4 & $\begin{array}{l}\text { Efficiency in agricultural production: A } \\
\text { Case of peasant farms in Eastern } \\
\text { Paraguay } \\
\text { [Bravo-Ureta dan Evenson, 1994] }\end{array}$ & $\begin{array}{l}\text { Umur, luas lahan, } \\
\text { pendidikan, penyuluhan } \\
\text { dan kredit }\end{array}$ & $\begin{array}{l}\text { SFA, fungsi produksi } \\
\text { model Cobb-Douglas }\end{array}$ \\
\hline 5 & $\begin{array}{l}\text { Economic efficiency in Organic } \\
\text { Frming: Evidence from Cotton Farms } \\
\text { in Viotia, Greece } \\
\text { [Tzouvelekas, et al, 2001] }\end{array}$ & $\begin{array}{l}\text { Efisiensi Teknis, alokatif } \\
\text { dan Ekonomi }\end{array}$ & $\begin{array}{l}\text { Stochastic frontier } \\
\text { analysis (SFA) }\end{array}$ \\
\hline 6 & $\begin{array}{l}\text { Determination of technical efficiency } \\
\text { in cotton growing farms in Turkey: A } \\
\text { case study of Cukurova region [Gull et } \\
\text { al., 2009] }\end{array}$ & $\begin{array}{l}\text { Umur petani, tingkat } \\
\text { pendidikan, kelompok tani } \\
\text { dan kepemilikan lahan }\end{array}$ & $\begin{array}{l}\text { DEA dan } \\
\text { Analisis regresi Tobit }\end{array}$ \\
\hline 7 & $\begin{array}{l}\text { Cotton Farmers' Technical Efficiency: } \\
\text { Stochastic and Non-stochastic } \\
\text { Production Function Approaches } \\
\text { Chakraborty, et al. 2002] }\end{array}$ & Sistem usahatani & $\begin{array}{l}\text { stochastic (SFA) dan } \\
\text { non stochastic, } \\
\text { Pendekatan fungsi } \\
\text { produksi (DEA). }\end{array}$ \\
\hline 8 & $\begin{array}{l}\text { An analysis of productive efficiency of } \\
\text { smallholder farms of cotton-wheat } \\
\text { system in Punjab, Pakistan } \\
\text { [Javed et al. 2011] }\end{array}$ & $\begin{array}{l}\text { Efisiensi teknis, alokatif } \\
\text { dan ekonomi }\end{array}$ & $\begin{array}{l}\text { Data Envelopment } \\
\text { Analysis (DEA) dan } \\
\text { Stochastic Frontier } \\
\text { Anaysis (SFA) }\end{array}$ \\
\hline 9 & $\begin{array}{l}\text { Analisis Efisiensi dan Daya Saing } \\
\text { Usahatani Jagung Pada Lahan Kering } \\
\text { di Kabupaten Tanah Laut Kalimantan } \\
\text { Selatan. [Kurniawan et al, 2008] }\end{array}$ & $\begin{array}{l}\text { lahan, benih, pupuk } \\
\text { organik, pupuk N, P,K, } \\
\text { pestisida, TK, umur, } \\
\text { pendidikan, pengalaman } \\
\text { dan keanggotaan KT Serta } \\
\text { PCR dan DRC }\end{array}$ & $\begin{array}{l}\text { Fungsi produksi } \\
\text { stochastic frontier. } \\
\text { fungsi biaya dual } \\
\text { frontier dan PAM }\end{array}$ \\
\hline 10 & $\begin{array}{l}\text { An examination of technical, allocative } \\
\text { and economic efficiencies in Ofada } \\
\text { rice farming in Ogun State, Nigeria } \\
\text { [Akinbode et al. 2011] }\end{array}$ & $\begin{array}{l}\text { efisiensi teknis, efisiensi } \\
\text { alokatif dan ekonomi }\end{array}$ & $\begin{array}{lr}\text { Deskriptif } & \text { statistik, } \\
\text { stochastic } & \text { frontier } \\
\text { analysis } & \text { (SFA) dan } \\
\text { analisis regresi Tobit. }\end{array}$ \\
\hline 11 & $\begin{array}{l}\text { Measurement and Determinants of } \\
\text { Production Efficiency among Small- } \\
\text { Holder Sweet Potato (Ipomoea Batatas) } \\
\text { Farmers in Imo State, Nigeria[Nwaru } \\
\text { et al. 2011] }\end{array}$ & $\begin{array}{l}\text { Efisiensi alokatif, teknis } \\
\text { dan ekonomi }\end{array}$ & $\begin{array}{ll}\text { Stochastic } & \text { frontier } \\
\text { analysis SFA } & \end{array}$ \\
\hline 12 & $\begin{array}{l}\text { Source of Technical Efficiency among } \\
\text { Smallholder Maize and Peanut Farmers } \\
\text { in the Slash and Burn Agriculture Zone } \\
\text { of Cameeroon [Binam et al, 2005] }\end{array}$ & Efisiensi teknis (TE) & $\begin{array}{lr}\text { Fungsi } & \text { produksi } \\
\text { stochastic } & \text { frontier dan } \\
\text { two-limit } & \text { Tobit } \\
\text { Reggression } & \\
\end{array}$ \\
\hline
\end{tabular}




\subsection{Kajian Perilaku Terhadap Risiko}

Menurut Adegeye dan Dittoh (1985), sebagian besar keputusan usahatani diambil di dalam lingkungan risiko dan ketidakpastian. Para petani harus membuat keputusan saat ini, yang akan mempengaruhi produksi usahataninya dimasa yang akan datang. Para petani tidak dapat memastikan kondisi cuaca, kebijakan pemerintah, dan perubahan-perubahan baru di dalam teknologi. Semuanya merupakan faktor-faktor yang mempersulit petani untuk memprediksikan hasil yang diperoleh dengan tepat.

Beberapa kajian empiris menunjukkan perilaku petani yang berbedabeda, yang secara umum dipengaruhi oleh tingkat penggunaan teknologi yang digunakan, seperti yang diungkapkan oleh Bryant et al. (2007) dan Liu (2008) pada kasus pertanian kapas transgenik, demikian pula penelitian Olarinde, et al. (2007) mengenai perilaku risiko petani jagung di daerah lahan kering Nigeria.

Bryant et al. (2007) melaporkan hasil pengujian risiko yang timbul akibat penggunaan teknologi transgenik. Laporan ini menyimpulkan bahwa Sebagian besar produsen netral tehadap risiko dan menghindari risiko dalam menentukan pemanfaatan teknologi gen secara luas di Arkansas Tenggara dan teknologi Roundup Ready di Arkansas Timur Laut. Meskipun terdapat perbedaan harga akibat perubahan teknologi, preferensi petani terhadap teknologi akan berubah bergantung pada sikap petani terhadap risiko.

Liu (2009) mengkaji peranan perilaku risiko individu dalam pengambilan keputusan terkait pilihan untuk mengadopsi salah suatu bentuk teknologi baru (biotechnology) di China. Survei dan percobaan lapangan dilakukan untuk menstimulasi pilihan risiko dari 320 petani Cina yang mengambil keputusan untuk mengadopsi biji kapas Bt yang dimodifikasi secara genetik, sebagai pengganti biji kapas tradisional pada tahun 1990-an. Penelitian ini menganalisis faktor-faktor yang menentukan penggunaan pestisida pada usahatani kapas di China. Hasil analisisnya menunjukkan bahwa petani semakin menghindar terhadap risiko (risk averse), sehingga menggunakan semakin banyak pestisida. Petani yang tidak 
begitu takut terhadap risiko produksi, menggunakan pestisida yang lebih sedikit. Ketika petani memutuskan untuk menggunakan pestisida dalam jumlah besar, memaksimumkan keuntungan tidak lagi menjadi tujuan utama. Petani tersebut juga tidak memperhatikan kondisi kesehatannya dan kemungkinan keracunan pestisida. Hasil analisis ini memiliki implikasi kebijakan yang penting diantaranya: (1) memberikan jaminan atas kegagalan usahatani yang sangat diperlukan untuk mengurangi ketakutan petani dalam menghadapi risiko, (2) memberikan pelatihan untuk adopsi teknologi baru yang lebih menguntungkan dan dapat menurunkan penggunaan pestisida, dan (3) membuat aturan tentang pemasaran benih supaya di pasar tidak ada benih yang berkualitas rendah.

Olarinde et al, (2007) menggunakan analisis ekonometrik berdasarkan pendekatan ekonometrik Moscardi dan de Janvry (1977) untuk menentukan secara kuantitatif perilaku risiko individu sampel petani jagung di daerah lahan kering Nigeria. Hasil penelitian yang dilakukan menunjukkan bahwa, sekitar $8 \%$ petani menghindari risiko, $42 \%$ bersikap netral dan $50 \%$ sangat menolak terhadap risiko produksi jagung. Sekitar $72 \%$ dari variabel hipotesis ditemukan berpengaruh terhadap penghindaran risiko dari petani sampel. Variabel ini menjadi dasar rekomendasi kebijakan untuk mengatasi masalah yang dihasilkan dari empat jenis risiko yang diidentifikasikan dalam produksi jagung yaitu risiko alam, sosial, ekonomi dan teknis. Ini penting dalam upaya pemanfaatan teknologi budidaya dan untuk mengurangi kelaparan dan kemiskinan di Afrika.

Penelitian Antara (2005) yang dilaksanakan di Kecamatan Sigi Biromaru, Desa Jono Oge dan Desa Pakuli terhadap 66 responden, menggunakan analisis kuantitatif linear programming menyimpulkan bahwa perilaku petani dalam menentukan penggunaan faktor-faktor produksi lebih rasional di desa yang relatif jauh dari perkotaan, walaupun intensitas penyuluhan yang diterima lebih rendah dibandingkan dengan petani di daerah perkotaan.

Fariyanti et al. (2007) menganalisis perilaku ekonomi rumah tangga petani sayuran menggunakan model persamaan simultan. Data yang digunakan 
data cross section dengan sampel sebanyak 143 rumah tangga petani sayuran. Khusus untuk analisis risiko digunakan data panel pada tiga musim tanam. Analisis risiko produksi dilakukan dengan menggunakan model Generalized Autoregressive Conditional Heteroscedasticity (GARCH). Penelitian ini menemukan bahwa risiko produksi kentang maupun kubis dipengaruhi secara nyata oleh risiko produksi pada musim sebelumnya. Perilaku ekonomi rumah tangga petani sayuran dalam pengambilan keputusan produksi akibat risiko produksi dan harga produk adalah mengurangi penggunaan lahan, benih, pupuk, obat-obatan dan tenaga kerja. Dalam pengambilan keputusan alokasi tenaga kerja, rumah tangga petani sayuran akan meningkatkan penggunaan tenaga kerja pada kegiatan off farm dan non farm sebagai akibat adanya risiko produksi dan harga produk.

Maesaroh dan Juarini (2010) menggunakan model keputusan biner dari Pyndyck dan Rubinfield yang bertujuan menghubungkan probabilitas bersyarat (conditional probability) suatu keputusan tertentu dengan berbagai faktor penjelas yang terdiri dari karakteristik-karakteristik pengamatan. Penelitian ini menemukan hasil bahwa faktor-faktor yang mempengaruhi pengambilan keputusan petani melakukan diversifikasi jeruk siam dan cabai merah adalah modal dan pengalaman berusahatani di lahan pantai. Penelitian ini juga mengungkapkan bahwa setelah melakukan diversifikasi usahatani terjadi penurunan risiko usaha sebesar $26,74 \%$.

Hasil penelitian Saptana et al. (2010) yang menganalisis perilaku petani terhadap risiko usahatani cabai merah menunjukkan bahwa sebagian besar peubah baik yang sifatnya teknis maupun sosial ekonomi yang dimasukkan dalam model memiliki tanda yang sesuai harapan dan sebagian signifikan. Beberapa input bersifat sebagai pengurang risiko seperti penggunaan benih, pupuk N, PPC, dan tenaga kerja luar keluarga, sedangkan beberapa input lainnya bersifat sebagai pembangkit risiko. Rata-rata nilai efisiensi teknis (tennical efficiency_TE) baik tanpa maupun dengan memasukkan unsur risiko masing-masing sebesar 0,83 dan 0,82 , tetapi dengan sebaran TE yang berbeda. Proporsi petani yang mencapai TE 
lebih dari 0,80 masing-masing sebesar $(68,68 \%)$ tanpa memasukkan risiko dan $(71,71 \%)$ dengan memasukkan risiko. Perilaku petani cabai merah besar terhadap harga adalah berani mengambil risiko (risk taker).

Just dan Pope (1979) telah mengkritisi fungsi produksi tradisional yang memiliki keterbatasan dalam melihat pengaruh perubahan penggunaan input terhadap produk rata-rata dan variabilitas output. Berdasarkan restriksi ini Just dan Pope membuat model dari fungsi produksi yang terdiri dari dua komponen yaitu komponen pertama menjelaskan dampak input terhadap output yang diharapkan dan yang kedua menjelaskan dampak input terhadap variabilitas output. Dengan menggunakan data panel Just dan Pope menunjukkan bahwa pupuk nitrogen memiliki dampak meningkatkan variabilitas produktivitas artinya bahwa pemberian pupuk ini dapat meningkatkan risiko produksi (inducing risk).

Model lainnya yang dikembangkan oleh Kumbhakar juga telah digunakan oleh Bokusheva dan Hockmann (2005) dalam menentukan preferensi terhadap risiko. Studi ini melihat dampak risiko produksi dan inefisiensi teknis dari produsen pertanian di Rusia. Hasil yang didapat dari analisis terhadap 443 data panel menunjukkan bahwa inefisiensi teknis menjadi penyebab variabilitas produksi pertanian di Rusia. Selanjutnya risiko produksi juga memberikan kontribusi terhadap ketidakstabilan output pertanian Rusia. Hampir di semua usahatani pada semua lokasi (Krasnodar, Oroel, dan Samara) menunjukkan bahwa variabilitas output dapat dijelaskan oleh risiko produksi. 
Tabel 3.2. Review Penelitian Tentang Perilaku Petani Terhadap Risiko

\begin{tabular}{|c|c|c|c|}
\hline No. & Judul Penelitian & Variabel/pengamatan & Teknik Analisis \\
\hline 1 & $\begin{array}{l}\text { Valuing Transgenic Cotton } \\
\text { Technologies Using a Risk/Return } \\
\text { Framework } \\
\text { [Bryant et al. 2007] }\end{array}$ & $\begin{array}{l}\text { Teknologi terhadap risiko } \\
\text { conventional cultivars, } \\
\text { Roundup Ready cultivars, } \\
\text { Bollgard cultivars, }\end{array}$ & $\begin{array}{l}\text { Stochastic Efficiency } \\
\text { with Respect to a } \\
\text { Function (SERF) }\end{array}$ \\
\hline 2 & $\begin{array}{l}\text { Time to Change What to Sow: } \\
\text { Risk Preferences and Technology } \\
\text { Adoption Decisions of Cotton } \\
\text { Farmers in China } \\
\text { [Liu, 2009] }\end{array}$ & $\begin{array}{l}\text { Faktor-faktor yang } \\
\text { menentukan peng-gunaan } \\
\text { pestisida pada usahatani } \\
\text { kapas di China }\end{array}$ & Analisis ekonometrik \\
\hline 3 & $\begin{array}{l}\text { Attitudes Towards Risk Among } \\
\text { Maize Farmers in the Dry Savanna } \\
\text { Zone of Nigeria: Some } \\
\text { Prospective Policies forImproving } \\
\text { food production } \\
\text { [Olarinde et al. } 2007]\end{array}$ & $\begin{array}{l}\text { Risiko alam, sosial, } \\
\text { ekonomi dan teknis }\end{array}$ & $\Delta n$ \\
\hline 4 & $\begin{array}{l}\text { Perilaku Petani dalam } \\
\text { pengalokasian Ssumberdaya untuk } \\
\text { Mencapai Pendapatan Maksimum } \\
\text { di Kec. Sigi Biromaru Kab. } \\
\text { Donggala } \\
\text { [Antara, 2005] }\end{array}$ & daya tani & $\begin{array}{l}\text { Analisis kuantitatif } \\
\text { linear programming }\end{array}$ \\
\hline 5 & $\begin{array}{lll}\text { Perilaku Ekonomi Rumah Tangga } \\
\text { Sayuran pada } & \text { Kondisi Risiko } \\
\text { Produksi dan } & \text { Harga di Kec. } \\
\text { Pangalengan } & \text { Kab } & \text { Bandung } \\
\text { [Fariyanti et al. } 2007] & \end{array}$ & $\begin{array}{l}\text { Tenaga kerja off-farm } \\
\text { dan non-farm, } \\
\text { pendapatannon-farm, } \\
\text { pengeluaran non pangan }\end{array}$ & $\begin{array}{l}\text { Generalized Auto- } \\
\text { regressive Conditional } \\
\text { Heteroscedasticity } \\
\text { (GARCH). }\end{array}$ \\
\hline 6 & $\begin{array}{l}\text { Faktor-faktor yang } \text { Mem- } \\
\text { pengaruhi Pengambilan Keputusan } \\
\text { Petani Melakukan Diversifikasi } \\
\text { Usahatani di Lahan Pantai Desa } \\
\text { Garongan Kec.Panjatan } \\
\begin{array}{l}\text { Kulonprogo } \\
\text { Juarini, 2010] }\end{array}\end{array}$ & $\begin{array}{l}\text { Keuntungan, jumlah } \\
\text { tenaga kerja keluarga } \\
\text { yang tersedia, modal } \\
\text { yang dimiliki petani dan } \\
\text { pengalaman berusahatani }\end{array}$ & Model keputusan biner \\
\hline 7 & $\begin{array}{l}\text { Analisis Efisiensi Teknis Produksi } \\
\text { Usahatani Cabai Merah dan } \\
\text { Perilaku Petani dalam Menghadapi } \\
\text { Risiko } \\
\text { [Saptana et al. 2010] }\end{array}$ & Risiko produksi & Model Kumbhakar \\
\hline
\end{tabular}




\section{3..4. Daya Saing dalam Produksi Kapas}

Peningkatan daya saing perlu mendapat perhatian karena punya potensi besar dikembangkan di Indonesia. Ketersediaan pasokan bahan baku, tenaga kerja, dan teknologi yang relatif melimpah semestinya mampu dikembangkan lebih jauh. Menurut penelitian yang dilakukan Asia Development Bank (ADB) Institute, daya saing berarti kemampuan perusahaan untuk bersaing. Perusahaan memiliki strategi tersendiri untuk menurunkan biaya, meningkatkan kualitas produk, dan mendapatkan jaringan pemasaran. Pengembangan industri membutuhkan peningkatan daya saing di pasar domestik dan internasional. Daya saing produk Indonesia memang perlu mendapat perhatian dan secara sistematis harus ditingkatkan sebagai salah satu cara membangun perekonomian Indonesia. Oleh karena itu, dalam kaitan ini perlu diketahui ukuran daya saing industri Indonesia di pasar internasional sebagai landasan untuk melakukan analisis daya saing dan merumuskan upaya-upaya peningkatan daya saing dalam rangka pembangunan daya saing dan perekonomian nasional.

Penelitian tentang daya saing kapas menunjukkan hasil yang berbeda di beberapa tempat di Indonesia. Penelitian analisis daya saing kapas pernah dilakukan Suryana et al. (1997) yang menganalisis efisiensi finansial dan ekonomi serta tingkat keunggulan komparatif dan kompetitif pengusahaan serat kapas di Indonesia. Penelitian yang meliputi empat provinsi, yakni Sulawesi Selatan, Jawa Tengah, Jawa Timur, dan NTB memilih masing-masing dua kabupaten sentra produksi dan pada setiap kabupaten dipilih secara acak sekitar 30 petani kapas serta perusahaan pengelola/pengolah yang ada di kabupaten terpilih. Analisis yang digunakan dalam penelitian ini adalah analisis keunggulan komparatif dan kompetitif serta dampak kebijakan pemerintah dengan menggunakan analisis matrik kebijakan (Policy Analysis Matrix). Hasil penelitian menunjukkan bahwa pengusahaan serat kapas di Sulsel dan Jawa Tengah tahun 1993 dan 1994 menguntungkan, baik secara finansial maupun ekonomi, serta mempunyai keunggulan komparatif dan kompetitif. Namun jika dibandingkan keduanya, pengusahaan serat kapas di Sulsel relatif lebih efisien karena mempunyai 
keunggulan komparatif dan kompetitf yang lebih tinggi dibandingkan dengan Jawa Tengah. Sebaliknya, pengusahaan serat kapas di Jawa Timur dan NTB tidak menguntungkan dan tidak mempunyai keunggulan komparatif dan kompetitif.

Dampak kebijakan pemerintah terhadap input barang yang diperdagangkan, input domestik dan output ternyata menguntungkan produsen karena dapat meningkatkan nilai tambah. Hal ini terlihat dari nilai EPC pada ke empat daerah penelitian lebih besar dari satu yaitu berkisar antara 1,01 sampai 1,56. Keuntungan produsen di Sulsel relatif lebih besar dibandingkan di provinsi lainnya. Kebijakan pemerintah dan pengelola yaitu berupa subsidi pupuk dan benih terhadap petani dan fasilitas pengolahan kepada perusahaan pengelola/ pengolah serta bantuan-bantuan pemerintah lainnya seperti keterlibatan Dinas Perkebunan, Balittas dalam pengembangan produksi terutama penyediaan input menguntungkan produsen serat kapas sehingga dapat menekan biaya produksi. Walaupun efek dari kebijakan pemerintah terhadap output dan input tradable menguntungkan produsen (dapat dilihat dari nilai $\mathrm{NPCO}>1$, NPCL $<1$, dan EPC $>1$ ), tetapi karena terjadi kegagalan di pasar (terutama kenaikan input dan rendahnya harga kapas berbiji) maka produsen di ke empat provinsi masih menerima keuntungan yang lebih kecil dari keuntungan yang didapat di pasar persaingan sempurna (dapat dilihat dari nilai $\mathrm{PC}<1$ ).

Hasil penelitian lainnya berkaitan dengan efisiensi produksi dan daya saing kapas terus dilakukan di beberapa negara penghasil kapas, diantaranya Mohanty et al. (2003), Javed et al. (2006) di Pakistan serta Alabdullah dan Nuppenau, (2010) di Suria. Penelitian ini melaporkan perbedaan hasil di beberapa tempat terkait dengan indikator daya saing walaupun di analisis menggunakan model yang sama.

Mohanty et al. (2003) meneliti efisiensi produksi kapas di lima negara bagian penghasil utama kapas di India menggunakan Policy Analysis Matrix (PAM). Hasilnya mengindikasikan bahwa kapas tidak efisien untuk diproduksi di dua negara bagian penghasil kapas terbesar di negara tersebut. Tanpa intervensi 
pemerintah di negara bagian ini, ada kemungkinan bahwa areal kapas akan berpindah ke tanaman yang lebih menguntungkan seperti tebu dan kacang tanah. Kapas bukanlah tanaman yang paling efisien diproduksi di empat negara bagian lainnya, namun setidaknya masih terdapat tanaman di setiap negara bagian yang kurang efisien daripada kapas.

Policy Analysis Matrix juga digunakan Javed et al. (2006) khususnya menggunakan analisis DRC dan menyimpulkan bahwa para petani di Punjab memiliki keunggulan komparatif dalam memproduksi kapas berbiji pada periode 1998-2003 (nilai DRC Punjab dan Sindh, masing-masing 0,34 dan 0,26). Nilai NPC rata-rata di Punjab dan Sindh sama yakni 0,61, hal ini menunjukkan bahwa petani kapas di Punjab dikenakan pajak dalam usahataninya. Ini kemudian diperkuat oleh nilai EPC yang menunjukkan bahwa Sindh memiliki keuntungan komparatif dibandingkan Punjab yakni 0,54 berbanding 0,52.

Alabdullah dan Nuppenau (2010), mengkaji efisiensi produksi serat kapas di salah satu provinsi penghasil utama di Suriah dengan mempertimbangkan perbedaan sistem irigasi yang digunakan untuk memproduksi kapas. Efisiensi produksi dan keunggulan komparatif menggunakan modifikasi Policy Analysis Matrix (PAM). Hasil penelitian menunjukkan bahwa serat kapas yang diproduksi pada areal sekitar sungai tidak efisien, keunggulan komparatif usahatani kapas hanya dapat diperoleh dengan menggunakan sistem irigasi tetes yang memanfaatkan air sumur. Namun tanpa adanya intervensi pemerintah, ada kemungkinan bahwa areal di wilayah yang menggunakan metode irigasi konvensional akan pindah dari kapas ke tanaman yang lebih menguntungkan. 
Tabel 3.3. Review Hasil Penelitian Tentang Daya Saing Komoditi

\begin{tabular}{|c|c|c|c|}
\hline No. & Judul Penelitian & Variabel/pengamatan & Teknik Analisis \\
\hline 1. & $\begin{array}{l}\text { Keunggulan Komparatif, } \\
\text { Keunggulan Kompetitif dan } \\
\text { Dampak Kebijaksanaan } \\
\text { Pemerintah Dalam Produksi } \\
\text { Kapas Di Indonesia } \\
\text { [Suryana } \text { et al. 1997] }\end{array}$ & $\begin{array}{l}\text { Keunggulan komparatif } \\
\text { dan kompetitif serta } \\
\text { dampak kebijaksanaan } \\
\text { pemerintah }\end{array}$ & $\begin{array}{l}\text { Modifikasi Policy } \\
\text { Analysis Matrix } \\
\text { (PAM) }\end{array}$ \\
\hline 2. & $\begin{array}{l}\text { Assessing the Compe- } \\
\text { titiveness of Indian Cotton } \\
\text { Production: A Policy } \\
\text { Analysis Matrix Approach } \\
\text { [Mohanty et al., 2003] }\end{array}$ & Daya saing & $\begin{array}{l}\text { Modifikasi Policy } \\
\text { Analysis Matrix } \\
\text { PAM) }\end{array}$ \\
\hline 3 & $\begin{array}{l}\text { Comparative advantage of } \\
\text { Cotton Poduction and its } \\
\text { Policy Implications in } \\
\text { Pakistan } \\
\text { [Javed et al. 2006] }\end{array}$ & $\begin{array}{l}\text { Domestic Resouce Cost } \\
\text { (DRC), Nominal Protection } \\
\text { Coefficient (NPC) dan } \\
\text { Effective Protection } \\
\text { Coefficient (EPC) }\end{array}$ & $\begin{array}{l}\text { Policy Analysis } \\
\text { Matrix (PAM). }\end{array}$ \\
\hline 4 & $\begin{array}{l}\text { Assessing the Compe- } \\
\text { titiveness of Syrian Cotton } \\
\text { Production: A Policy } \\
\text { Analysis Matrix Approach } \\
\text { [Alabdullah dan Nuppenau, } \\
\text { 2010] }\end{array}$ & $\begin{array}{l}\text { Efisiensi Produksi dan } \\
\text { keunggulan komparatif }\end{array}$ & $\begin{array}{l}\text { Modifikasi Policy } \\
\text { Analysis Matrix } \\
\text { (PAM) }\end{array}$ \\
\hline
\end{tabular}




\subsection{Studi Pengembangan Kapas di Sulawesi Selatan}

\subsubsection{Metode Dasar}

Metode dasar yang digunakan dalam studi ini adalah metode deskriptif (Descriptive methods). Metode deskriptif dimaksudkan untuk melakukan pengukuran yang cermat terhadap fenomena sosial (Singarimbun dan Effendi 1989) dan menurut Nasir (1989) metode deskriptif menggambarkan hubungan antar fenomena, menguji hipotesis, dan membuat implikasi dari suatu masalah yang ingin dipecahkan.

Studi ini untuk mengestimasi tingkat efisiensi produksi (efisiensi teknis, efisiensi alokatif dan efisiensi ekonomi), mengetahui perilaku petani terhadap risiko usahatani kapas rakyat serta meramalkan dampak kebijakan kapas nasional terhadap daya saing (keunggulan komparatif dan kompetitif) usahatani kapas di Sulsel, sehingga pemecahannya diestimasi dengan menggunakan fungsi produksi stochastic frontier seperti yang dilakukan oleh Aigner et al. (1977) serta Battese dan Coelli (1988). Perilaku petani terhadap risiko dianalisis mengacu pada metode Moscardi dan De Janvry (1977), metode ini memilih variabel yang paling nyata berpengaruh berdasarkan hasil regresi fungsi produksi yang bersifat stochastic. Sementara analisis daya saing menggunakan Policy Analysis Matrix (PAM) (Monke dan Pearson, 1995) dengan menghitung Rasio Biaya Privat (Private Cost Ratio, PCR) yang merupakan kriteria keunggulan kompetitif serta Rasio Biaya Sumber Daya Domestik (Domestic Resources Cost Ratio, DRC) sebagai kriteria keunggulan komparatif dari usahatani kapas rakyat.

\subsubsection{Penentuan Lokasi}

Penentuan Sulawesi Selatan sebagai lokasi studi atas dasar bahwa potensi produksi terbesar dihasilkan di provinsi tersebut, yakni sebesar $48 \%$ dari produksi nasional (Ditjenbun, 2010). Dari provinsi terpilih selanjutnya ditentukan lokasi penelitian dengan menggunakan teknik multistage sampling, dengan cara purposive pada tingkat kabupaten, kecamatan dan desa yang merupakan sentra 
produksi kapas di Sulawesi Selatan. Penentuan sampel diawali pada tingkat kabupaten, meliputi sentra produksi di daerah Sulsel bagian Selatan (Kabupaten Bulukumba) dan Sulsel bagian Utara (Kabupaten Bone dan Soppeng). Selanjutnya berdasarkan pertimbangan yang sama serta ketersediaan sampel ditentukan masing-masing satu kecamatan contoh dan dilanjutkan dengan menentukan satu desa pada masing-masing kecamatan.

\subsubsection{Pengumpulan Data dan Informasi}

Pengumpulan data mencakup data sekunder dan data primer. Data sekunder diperoleh dari instansi pemerintah yang menangani komoditas kapas (Dinas Perkebunan, kantor statistik, kantor kecamatan, kantor desa dan lain-lain) baik di tingkat pusat maupun daerah/provinsi dan kabupaten.

Data primer diperoleh dari petani kapas melalui pengamatan langsung di lapangan dengan teknik wawancara melalui pengisian daftar pertanyaan/kuesioner yang telah dipersiapkan. Sampel petani kapas ditentukan secara simple random sampling, dengan mengambil sebanyak 150 petani sampel yang didistribusi pada masing-masing kabupaten berdasarkan jumlah petani pada masing-masing sampel lokasi/desa (Tabel 3.4). Sedangkan untuk informasi umum dan kebijakan dilakukan wawancara group kepada narasumber terkait mulai dari tingkat provinsi sampai ke tingkat desa terpilih.

Tabel 3.4. Sebaran Sampel Penelitian Menurut Lokasi Penelitian

\begin{tabular}{|c|c|c|c|c|c|}
\hline \multirow{2}{*}{ No } & \multicolumn{2}{|c|}{ Lokasi } & \multirow{2}{*}{ Desa/Kel } & \multirow{2}{*}{$\begin{array}{c}\text { Jumlah } \\
\text { Petani (org) }\end{array}$} & \multirow{2}{*}{$\begin{array}{l}\text { Jumlah } \\
\text { Sampel }\end{array}$} \\
\hline & Kabupaten & Kecamatan & & & \\
\hline 1 & Bulukumba & Herlang & Tanuntung & 242 & 70 \\
\hline 2 & Soppeng & Marioriwawo & Goarie & 112 & 30 \\
\hline \multirow[t]{2}{*}{3} & Bone & Tellusiattinge & Ulo & 173 & 50 \\
\hline & & & Total & 527 & 150 \\
\hline
\end{tabular}

Sumber : Data Primer, 2012. 


\subsubsection{Definisi Operasional dan Pengukuran Variabel}

Variabel yang diamati pada studi ini merupakan data dan informasi usahatani kapas. Variabel penelitian ini terlebih dahulu didefinisikan untuk mempermudah proses pengumpulan data. Berikut ini adalah definisi variabel yang digunakan.

1) Produksi kapas adalah besarnya produksi yang dihasilkan dari usatahani kapas dalam setiap satu satuan luas lahan dalam satu musim tanam. Bentuk produksi adalah serat kapas berbiji, dinyatakan dalam satuan kilogram (kg).

2) Luas lahan adalah luas lahan yang digarap untuk usahatani kapas pada musim tanam 2011/2012. Satuan ukurannya adalah hektar (ha)

3) Benih adalah jumlah benih yang digunakan dalam kegiatan usahatani kapas, dihitung dalam satuan kilogram $(\mathrm{kg})$.

4) Pupuk Urea adalah jumlah pupuk Urea yang digunakan dalam kegiatan usahatani kapas, dinayatakan dalam kilogram $(\mathrm{kg})$.

5) Pupuk ZA adalah pupuk jumlah ZA yang digunakan dalam kegiatan usahatani kapas dinyatakan dalam kilogram $(\mathrm{kg})$.

6) Pupuk NPK adalah jumlah pupuk NPK yang digunakan dalam kegiatan usahatani kapas, dinyatakan dalam kilogram $(\mathrm{kg})$.

7) Pupuk SP-36 adalah jumlah pupuk SP-36 yang digunakan dalam kegiatan usahatani kapas, dinyatakan dalam kilogram $(\mathrm{kg})$.

8) Insektisida adalah jumlah insektisida yang digunakan dalam kegiatan usahatani kapas, dinyatakan dalam gram (gr).

9) Herbisida adalah jumlah Herbisida yang digunakan dalam kegiatan usahatani kapas, dinyatakan dalam liter (ltr).

10) Tenaga kerja adalah jumlah penggunaan tenaga kerja dalam usaha tani kapas per satuan unit lahan baik yang bersumber dari TK keluarga maupun TK upahan yang dinyatakan dalam jam kerja setara pria. Dinyatakan dalam hari orang kerja setara pria dengan $\mathrm{HOK}$, untuk penyederhanaan akan dibuat penyetaraan $1 \mathrm{HOKW}=0,8 \mathrm{HOKP}$. 
11) Umur petani adalah usia petani saat musim tanam kapas, dengan satuan pengukuran yang digunakan yaitu tahun (thn).

12) Pengalaman usahatani adalah lamanya petani dalam mengusahakan usahatani kapas, dengan satuan pengukuran yang digunakan yaitu tahun (thn)

13) Pendidikan formal adalah lamanya pendidikan formal yang pernah diperoleh petani, dengan satuan pengukuran tahun (thn).

14) Jumlah anggota keluarga adalah jumlah anggota keluarga petani kapas, dengan satuan pengukuran yang digunakan yaitu orang (org).

15) Lama bergabung dalam kelompok tani adalah lamanya waktu petani bergabung dalam kelompok tani kapas, dengan satuan tahun (thn).

16) Biaya total adalah total biaya yang dikeluarkan oleh petani kapas dalam proses produksi kapas, dinyatakan dalam rupiah (Rp).

17) Biaya Privat atau biaya finansial adalah keseluruhan biaya penggunaan input pada usahatani kapas yang didasarkan pada harga aktual yang yang berlaku dipasaran, dinyatakan dalam satuan rupiah $(\mathrm{Rp})$.

18) Biaya Sosial atau biaya ekonomi adalah keseluruhan biaya penggunaan input pada usahatani kapas yang didasarkan pada estimasi social opportunity cost nya, dinyatakan dalam satuan rupiah (Rp).

19) Harga aktual input produksi adalah harga yang berlaku di pasar di tingkat petani terhadap semua sarana produksi yang digunakan dalam usahatani kapas, diukur dalam satuan rupiah $(\mathrm{Rp})$ per unit jenis input produksi yang digunakan.

20) Harga bayangan input produksi, yaitu harga sosial atau eknomi di tingkat petani dari input produksi yang digunakan dalam usahatani kapas, diukur dalam satuan rupiah (Rp) per unit jenis input produksi yang digunakan.

\subsubsection{Metode Analisis Data}

\section{a. Analisis Fungsi Produksi}

Fungsi produksi yang digunakan adalah fungsi produksi stochastic frontier seperti yang dilakukan oleh Aigner et al. (1977) dan Meeusen dan Broeck 
(1977) serta Coelli et al. (1988). Bentuk umum fungsi produksi stochastic frontier adalah sebagai berikut.

$Y_{i}=f\left(X_{l i} \beta\right)$

Keterangan:

$\mathrm{Y}_{\mathrm{i}}=$ keluaran yang dihasilkan oleh observasi ke-i,

$\mathrm{X}_{1 \mathrm{i}}=$ vektor masukan $\mathrm{L}$ yang digunakan oleh observasi ke-i

$\beta=$ vektor koefisien parameter

$\varepsilon_{\mathrm{i}} \quad=$ "galat khusus" dari observasi ke-i $=\mathrm{v}_{\mathrm{i}}-\mathrm{u}_{\mathrm{i}}$

Fungsi produksi stochastic frontier mempunyai galat khusus $\varepsilon_{\mathrm{i}}$ sehingga model yang menggunakan fungsi produksi tersebut disebut composed error model. Sifat kekhususannya adalah bahwa galat ini terdiri dari dua unsur galat $\mathrm{vi}_{\mathrm{i}}$ dan $\mathrm{u}_{\mathrm{i}}$ yang masing-masing mempunyai sebaran yang berbeda. Galat vi menangkap kesalahan variasi keluaran yang disebabkan oleh faktor-faktor internal yaitu faktor-faktor yang dapat dikelola oleh produsen. Sebarannya diasumsikan asimetris dan distribusinya setengah normal. Dengan demikian ragam totalnya adalah:

$$
\begin{gathered}
\sigma^{2} \equiv \sigma_{\mathrm{u}}^{2}+\sigma_{\mathrm{v}}^{2} \\
\lambda=\stackrel{\sigma_{\mathrm{u}}}{\sigma_{\mathrm{v}}}
\end{gathered}
$$

Menurut Battese dan Corra (1977) variasi total keluaran aktual terhadap frontier-nya adalah: $\quad \gamma \equiv \frac{\sigma_{\mathrm{u}}}{\delta_{\mathrm{v}}}$

Dalam penelitian ini model operasional yang dipakai adalah model fungsi produksi stochastic frontier Cobb-Douglas sebagai berikut.

$$
\begin{aligned}
\ln \text { Prod }= & \beta_{0}+\beta_{1} \ln \mathrm{Lh}+\beta_{2} \ln \mathrm{Bnh}+\beta_{3} \ln \mathrm{Ur}+\beta_{4} \ln \mathrm{Npk}+\beta_{5} \ln \mathrm{Za}+ \\
& \beta_{6} \ln \mathrm{Sp}+\beta_{7} \ln \operatorname{Ins}+\beta_{8} \ln \mathrm{Her}+\beta_{9} \ln \mathrm{Tk}+\left(\mathrm{v}_{\mathrm{i}}-\mathrm{u}_{\mathrm{i}}\right) \ldots \ldots \ldots
\end{aligned}
$$

Keterangan:

$\ln$ Prod $=$ produksi $\operatorname{kapas}(\mathrm{kg})$

$\ln \mathrm{Lh}=$ luas lahan (ha)

$\ln \mathrm{Bnh}=$ jumlah benih $(\mathrm{kg})$ 
$\ln \mathrm{Ur}=$ jumlah pupuk Urea $(\mathrm{kg})$

ln Npk = jumlah pupuk NPK $(\mathrm{kg})$

$\ln \mathrm{Za}=$ jumlah pupuk $\mathrm{ZA}(\mathrm{kg})$

$\ln \mathrm{Sp}=$ jumlah pupuk SP-36 $(\mathrm{kg})$

$\ln$ Ins $=$ jumlah insektisida (gr)

ln Her = jumlah herbisida (ltr)

$\ln \mathrm{Tk}=$ tenaga kerja $(\mathrm{HOK})$

$\beta_{0} \quad=$ intersep

$\beta_{1}-\beta_{9}=$ koefisien parameter penduga

$\mathrm{v}_{\mathrm{i}}-\mathrm{u}_{\mathrm{i}}=$ error term $\left(\mathrm{u}_{\mathrm{i}}=\right.$ efek inefisiensi dalam model $)$

\section{b. Analisis Efisiensi Teknis dan Inefisiensi Teknis}

Efisiensi teknis (Technical Efficiency_TE) usahatani kapas dalam penelitian ini menggunakan Stochactic Production Frontier yang diintroduksikan oleh Aigner et al. (1977) yang mendefinisikan bahwa $\mathrm{u}_{\mathrm{it}}$ merupakan komponen dari specific error term $\left(\varepsilon_{\mathrm{it}}\right)$ yakni $\varepsilon_{\mathrm{it}}=\mathrm{v}_{\mathrm{it}}+\mathrm{u}_{\mathrm{it}}$. Bentuk umum dari ukuran efisiensi teknis yang dicapai oleh observasi ke-i pada waktu ke-t didefiniskan sebagai berikut (Coelli, 1996; dan Coelli et al., 1988).

$$
\begin{aligned}
& \mathrm{TE}_{\mathrm{i}}=\frac{\mathrm{Y}_{\mathrm{i}}}{\mathrm{Y}_{\mathrm{i}}^{*}}=\frac{\mathrm{E}\left(\mathrm{Y}_{\mathrm{i}} \mid \mathrm{U}_{\mathrm{i}}, \mathrm{X}_{\mathrm{i}}\right)}{\mathrm{E}\left(\mathrm{Y}_{\mathrm{i}} \mid \mathrm{U}_{\mathrm{i}}=0, \mathrm{X}_{\mathrm{i}}\right)}=\mathrm{E}\left[\exp \left(-\mathrm{U}_{\mathrm{i}} \mid \varepsilon\right)\right. \\
& \mathrm{TE}=\mathrm{E}\left[\exp \left(-\mathrm{U}_{\mathrm{i}} \mid \varepsilon\right) \quad \mathrm{i}=1,2.3, \ldots ., \mathrm{n}\right.
\end{aligned}
$$

Keterangan

$\mathrm{TE}_{\mathrm{i}}=$ efisiensi teknis petani ke-i,

$\mathrm{Y}_{\mathrm{i}}=$ fungsi output deterministik (tanpa error term), dan

$\mathrm{u}_{\mathrm{i}}=$ peubah acak yang menggambarkan inefisiensi teknis dari usahatani ke-i yang diasumsikan bebas dan distribusinya terpotong normal dengan $N\left(\mu_{\mathrm{i}}\right.$, $\sigma^{2}$ ).

Adapun ukuran efisiensi teknis individual petani dapat dihitung dari nilai harapan $\mathrm{u}_{\mathrm{it}}$ dengan syarat $\varepsilon_{\mathrm{it}}$ sebagai berikut (Jondrow et al., 1982). 
$\mathrm{E}\left(\mathrm{U}_{\mathrm{i}} \mid \varepsilon_{\mathrm{i}}\right)=\frac{\sigma_{\mathrm{u}} \sigma_{\mathrm{v}}}{\sigma}\left[\frac{\mathrm{f}\left(\frac{\varepsilon_{\mathrm{i}} \lambda}{\sigma}\right)}{1-\mathrm{F}\left(\frac{\varepsilon_{\mathrm{i}} \lambda}{\delta}\right)}-\frac{\varepsilon_{\mathrm{i}} \lambda}{\sigma}\right] \quad \mathrm{i}=1,2,3 \ldots, \mathrm{n}$

Keterangan :

$\mathrm{f}(\bullet$ ) dan F (•) masing-masing merupakan fungsi densitas standar normal dan fungsi distribusi standar normal. Oleh karena $\mathrm{N}\left(\mu_{\mathrm{i}}, \sigma^{2}\right)$ non negatif maka besaran TE berada pada selang $0-1$ atau $0 \leq \mathrm{TE}_{\mathrm{i}} \leq 1$.

Untuk menentukan nilai parameter distribusi $\left(\mu_{\mathrm{i}}\right)$ efek inefisiensi teknis dalam penelitian ini menggunakan rumus sebagai berikut.

$\mu_{\mathrm{i}}=\delta_{0}+\delta_{1} \ln \mathrm{Um}+\delta_{2} \ln \mathrm{Pgl}+\delta_{3} \ln \mathrm{Pd}+\delta_{4} \ln \mathrm{Rt}$

$$
+\delta_{5} \ln \mathrm{Kt}
$$

Keterangan :

$\mu \mathrm{i} \quad=$ efek inefisiensi teknis

$\ln \mathrm{Um}=$ umur petani (tahun),

$\ln \mathrm{Pgl}=$ pengalaman usahatani (tahun),

$\ln \mathrm{Pd}=$ pendidikan formal (tahun),

ln Rt = jumlah anggota rumah tangga (orang), dan

$\ln \mathrm{Kt}=$ lama bergabung dalam kelompok tani (tahun).

$\delta_{0} \quad=$ intersep

$\delta_{1}-\delta_{5}=$ koefisien parameter penduga

Pendugaan parameter dari model tersebut di atas diduga dengan metode maximum likelihood (MLE) dengan memakai program komputasi Frontier versi 4.1 yang dikembangkan oleh Coelli (1996). Agar konsisten maka pendugaan parameter fungsi produksi dan fungsi inefisiensi (persamaan 3.4 dan persamaan 3.6) dilakukan secara simultan. Program Frontier 4.1 mengikuti 3 langkah prosedur pendugaan yaitu:

1. OLS, untuk memperoleh semua nilai parameter dugaan (kecuali intersep) yang tidak bias.

2. Grid search nilai $\gamma$.

3. Nilai yang diperoleh dari langkah 2 dipakai sebagai nilai awal pada prosedur iterative untuk memperoleh nilai penduga maximum likelihood.

Efek inefisiensi pada model di atas diuji dengan menggunakan metode statistik menurut Battese dan Corra (1977) yaitu maximum likelihood estimation 
(MLE). Hasil pengolahan dengan menggunakan Frontier versi 4.1 akan memberikan nilai perkiraan varians dari parameter dalam bentuk parameterisasi berikut ini.

Keterangan;

$$
\sigma^{2} \equiv \sigma_{\mathrm{u}}^{2}+\sigma_{\mathrm{v}}^{2} \quad \text { dan } \quad \gamma \equiv \frac{\sigma_{\mathrm{u}}}{\delta_{\mathrm{v}}}
$$

$\sigma^{2}=$ varians dari distribusi normal,

$\sigma_{\mathrm{u}}^{2}=$ varians dari vi, dan

$\sigma_{\mathrm{v}}^{2}=$ varians dari ui.

Nilai parameter $\gamma$ merupakan kontribusi dari efisiensi teknis di dalam residual error $(\varepsilon)$ yang nilainya berkisar antara nol dan satu. Nilai parameter $\gamma$ yang mendekati nol mengindikasikan bahwa deviasi dari frontier semakin mengarah pada efek residual (error), sedangkan nilai yang mendekati satu mengindikasikan bahwa deviasi semakin mengarah pada efek inefisiensi teknis.

\section{c. Analisis Efisiensi Ekonomis dan Alokatif}

Pengukuran efisiensi ekonomis dan alokatif dapat dilakukan dengan menurunkan fungsi biaya dual dari fungsi produksi. Caranya dengan meminimumkan fungsi biaya input dengan kendala fungsi produksi pada persamaan (3.5) sehingga diperoleh fungsi biaya dual frontier sebagai berikut.

$$
\begin{aligned}
\ln \text { BProd }= & \alpha_{0}+\alpha_{1} \ln \text { HUr }+\alpha_{2} \ln \text { HNpk }+\alpha_{3} \ln \text { HSp }+\alpha_{4} \ln \text { HIns }+ \\
& \alpha_{5} \ln \text { Her }+\alpha_{6} \ln \text { HTk }+\alpha_{7} \ln \text { Prod }+\left(v_{i}+u_{i}\right) \ldots \ldots \ldots \ldots
\end{aligned}
$$

Keterangan:

$$
\begin{array}{ll}
\ln \mathrm{BProd} & =\text { total biaya produksi }(\mathrm{Rp}) \\
\ln \mathrm{HUr} & =\text { harga Urea }(\mathrm{Rp} / \mathrm{kg}) \\
\ln \mathrm{HNpk} & =\text { harga NPK }(\mathrm{Rp} / \mathrm{kg}) \\
\ln \mathrm{HSp} & =\text { harga SP-36 }(\mathrm{Rp} / \mathrm{kg}) \\
\ln \mathrm{HIns} & =\text { harga insektisida }(\mathrm{Rp} / \mathrm{gr}) \\
\ln \mathrm{HHer} & =\text { harga herbisida }(\mathrm{Rp} / \mathrm{ltr}) \\
\ln \mathrm{HTk} & =\text { upah tenaga } \mathrm{kerja}(\mathrm{Rp} / \mathrm{HOK}) \\
\ln \text { Prod } & =\text { jumlah produksi/output }(\mathrm{kg}) \\
\alpha_{0} & =\text { intersep } \\
\alpha_{1}-\alpha_{7} & =\text { koefisien parameter penduga } \\
\mathrm{v}_{\mathrm{i}}+\mathrm{u}_{\mathrm{i}} & =\text { error term }
\end{array}
$$


Manurut Jondrow et al. (1982), Efisiensi Ekonomi (EE) usahatani kapas didefinisikan sebagai rasio minimum yang diamati dari total biaya produksi $\left(\mathrm{C}^{*}\right)$ dengan biaya produksi aktual secara keseluruhan (C) dengan menggunakan hasil Persamaan (3.5).

$$
\mathrm{EE}=\frac{\mathrm{C}_{\mathrm{i}}}{\mathrm{C}_{\mathrm{i}}^{*}}=\frac{\mathrm{E}\left(\mathrm{C}_{\mathrm{i}} \mid \mathrm{U}_{\mathrm{i}}\right)=0, \mathrm{Y}_{\mathrm{i}} \mathrm{P}_{\mathrm{i}}}{\mathrm{E}\left(\mathrm{Y}_{\mathrm{i}} \mid \mathrm{U}_{\mathrm{i}}, \mathrm{Y}_{\mathrm{i}} \mathrm{P}_{\mathrm{i}}\right)}=\mathrm{E}\left[\exp \left(-\mathrm{U}_{\mathrm{i}} \mid \varepsilon\right)\right]
$$

Nilai EE berada antara 0 dan 1. Menurut Ogundari dan Ojo (2006) dengan menggunakan program kumputer Frontier 4.1, akan diperoleh nilai Cost Efficiency (CE), yang pada awalnya dihitung sebagai invers persamaan (3.8). Oleh karena itu, tingkat efisiensi ekonomi (EE) usahatani di peroleh sebagai invers dari CE menggunakan hubungan berikut.

$$
\mathrm{EE}=\frac{1}{\text { Cost Efficiency (CE) }}
$$

Efisiensi ekonomi (Economic Efficiency_EE) merupakan gabungan dari efisiensi teknis (Technical Efficiency_TE) dan efisiensi alokatif (Allocative Efficiency_AE), sehingga efisiensi alokatif (AE) diperoleh dari persamaan.

$$
\mathrm{AE}=\frac{\text { Economic Efficiency }(\mathrm{EE})}{\text { Technical Efficiency }(\mathrm{TE})}
$$

Penentuan tingkat efisiensi masing-masing dibuat mengacu pada penelitian sebelumnya (Ogundari dan Ojo, 2007; Nwaru et al, 2011; Laha dan Kuri, 2011), dengan membagi tingkat efisiensi sebagai berikut.

a) Sangat efisien : $\mathrm{TE}, \mathrm{EE}$ dan $\mathrm{AE} \geq 0,90$

b) Cukup efisien : $0,70 \leq \mathrm{TE}, \mathrm{EE}$ dan $\mathrm{AE}<0,90$

c) Belum efisien : $\mathrm{TE}, \mathrm{EE}$ dan $\mathrm{AE}<0,70$.

\section{d. Pengujian Hipotesis Faktor Produksi dan Efisiensi}

Uji hipotesis dilakukan untuk menguji hasil output fungsi produksi dan efek efisiensi teknis frontier. Uji hipotesis untuk output fungsi produksi dilakukan dengan menggunakan uji parameter dugaan $\beta_{\mathrm{i}}$ untuk melihat 
ada tidaknya pengaruh masing-masing variabel penjelas di dalam model fungsi produksi. Uji hipotesis untuk model efek inefisiensi teknis menggunakan uji parameter dugaan $\gamma$ untuk mengetahui ada tidaknya efek inefisiensi di dalam model, sedangkan nilai t-hitung untuk masing-masing variabel penduga digunakan secara statistik untuk mengetahui apakah koefisien dari masingmasing parameter bebas $\left(\delta_{\mathrm{i}}\right)$ yang dipakai secara terpisah berpengaruh nyata atau tidak terhadap parameter tak bebas $\left(\mu_{i}\right)$.

\section{Hipotesis Variabel Yang Mempengaruhi Produksi}

$\mathrm{H}_{0}: \beta_{\mathrm{i}}=0$

$\mathrm{H}_{1}: \beta_{\mathbf{i}} \neq 0$

Hipotesis nol artinya koefisien dari masing-masing variabel di dalam model fungsi produksi sama dengan nol. Apabila hipotesis ini diterima, maka masing-masing variabel penjelas di dalam model fungsi produksi tidak memiliki pengaruh terhadap produksi kapas

\section{$\underline{\text { Hipotesis Efek Inefisiensi }}$}

$\mathrm{H}_{0}: \gamma=0$

$\mathrm{H} 1: \gamma>0$

Hipotesis nol artinya efek inefisiensi teknis tidak ada dalam model fungsi produksi. Jika hipotesis ini diterima, maka model fungsi produksi rata-rata sudah cukup mewakili data empiris.

\section{Hipotesis Faktor Yang Mempengaruhi Inefisiensi}

$\mathrm{H}_{0}: \delta_{\mathrm{i}}=0$

$\mathrm{H}_{1}: \delta_{\mathrm{i}} \neq 0$

Hipotesis nol artinya koefisien masing-masing variabel di dalam model efek inefisiensi sama dengan nol. Apabila hipotesis ini diterima, maka masingmasing variabel penjelas di dalam model efek inefisiensi tidak memiliki pengaruh sama sekali terhadap tingkat inefisiensi di dalam proses produksi.

\section{$\underline{\text { Hipotesis Efisiensi Produksi }}$}

$\mathrm{H}_{0}: \mathrm{TE}, \mathrm{AE}, \mathrm{EE} \geq 0,70$ dan $<0,90$ 
$\mathrm{H} 1: \mathrm{TE}, \mathrm{AE}, \mathrm{EE}<0,70$ dan $\geq 0,90$

\section{e. Analisis Perilaku Petani terhadap Risiko}

Analisis perilaku petani terhadap risiko produksi usahatani kapas pada penelitian ini mengacu metode Moscardi dan De Janvry (1977). Metode ini memilih variabel yang paling nyata berpengaruh yang menentukan hasil dari regresi fungsi produksi, dimana parameter variabel yang paling berpengaruh tersebut selanjutnya digunakan untuk menentukan tingkat perilaku petani dalam menghindari risiko berdasarkan pendekatan ekonometrika.

Model persamaan yang digunakan untuk menentukan variabel yang paling nyata berpengaruh adalah fungsi produksi Cobb-Douglas berikut ini.

$\begin{aligned} \ln \mathrm{Y}_{\mathrm{i}}= & \beta_{0}+\beta_{1} \ln \mathrm{Bnh}+\beta_{2} \ln \mathrm{Ur}+\beta_{3} \ln \mathrm{Npk}+\beta_{4} \ln \mathrm{Za}+\beta_{5} \ln \mathrm{Sp}+ \\ & \beta_{6} \ln \operatorname{Ins}+\beta_{7} \ln \mathrm{Her}+\beta_{8} \ln \mathrm{Tk}+\varepsilon \ldots \ldots \ldots \ldots \ldots \ldots \ldots \ldots \ldots \ldots \ldots \ldots \ldots \ldots \ldots \ldots \ldots \ldots \ldots \ldots \ldots \ldots\end{aligned} \ldots$

Keterangan:

$\mathrm{Y}_{\mathrm{i}} \quad=$ produktivitas kapas $(\mathrm{kg} / \mathrm{ha})$

$\mathrm{Bnh}=$ jumlah benih $(\mathrm{kg} / \mathrm{ha})$

$\mathrm{Ur} \quad=$ jumlah pupuk Urea $(\mathrm{kg} / \mathrm{ha})$

$\mathrm{Npk}=$ jumlah pupuk NPK $(\mathrm{kg} / \mathrm{ha})$

$\mathrm{Za} \quad=$ jumlah pupuk ZA $(\mathrm{kg} / \mathrm{ha})$

$\mathrm{Sp} \quad=$ jumlah pupuk SP-36 $(\mathrm{kg} / \mathrm{ha})$

Ins = jumlah insektisida $(\mathrm{gr} / \mathrm{ha})$

Her $=$ jumlah herbisida $($ ltr/ha $)$

$\mathrm{Tk}=$ tenaga kerja $(\mathrm{HOK} / \mathrm{ha})$

$\beta_{0} \quad=$ intersep

$\beta_{1}-\beta_{8}=$ koefisien parmeter penduga

$\varepsilon=$ error term

Tahapan analisis yang dilakukan sebagai berikut;

a. Menaksir model fungsi produksi Cobb-Douglas melalui metode ordinary least square (OLS) untuk memperoleh koefisien regresi, koefisien determinasi $\left(\mathrm{R}^{2}\right)$ dan sebagainya menggunakan program SPSS.

b. Mencari nilai $\mathrm{k}$ melalui pemilihan variabel yang paling nyata berpengaruh, kemudian digunakan untuk menentukan tingkat perilaku petani dalam 
menghindari risiko, dimana nilai parameter menghindari risiko diperoleh dari persamaan berikut.

$$
\theta=\frac{\delta \mathrm{y}}{\mu \mathrm{y}}
$$

Keterangan :

$\theta=$ koefisien variasi hasil

$\delta_{\mathrm{y}}=\quad$ standar deviasi dari hasil

$\mu_{\mathrm{y}}=$ rata-rata hasil

Hasil dari kondisi tingkat pertama adalah:

$$
\mathrm{P}_{\mathrm{y}} \mathrm{f}_{\mathrm{i}} \frac{\mu \mathrm{y}}{\mathrm{Xi}}=\frac{\mathrm{Pi}}{1-\theta \mathrm{K}(\mathrm{s})}
$$

Keterangan :

$\mathrm{P}_{\mathrm{i}}=$ harga input;

$\mathrm{X}_{\mathrm{i}}=$ vektor input yang paling nyata;

$\mathrm{P}_{\mathrm{y}}=$ harga output;

$\mathrm{f}_{\mathrm{i}}=$ elastisitas produksi dari input ke-i;

$\mathrm{K}_{(\mathrm{s})}=$ parameter menghindari risiko;

Nilai parameter menghindari risiko diperoleh dari persamaan berikut:

$$
\mathrm{K}_{(\mathrm{s})}=\frac{1}{\theta}\left[1-\frac{\mathrm{Pi} \cdot \mathrm{Xi}}{\text { Py.fi. } \mu \mathrm{y}}\right]
$$

Persamaan (3.11) menyediakan ukuran perilaku menghindari risiko $\mathrm{K}_{\mathrm{s}}$ dari masing-masing petani dari pengetahuan fungsi produksi, koefisien variasi hasil, harga produk dan faktor produksi dan tingkat penggunaan input.

Mengacu Moscardi dan De Janvry (1977), parameter menghindari risiko $\mathrm{K}_{(\mathrm{s})}$ digunakan untuk mengklasifikasikan petani menjadi 3 kelompok:

a) Memilih risiko (risk lover) $=\left(0<\mathrm{K}_{(\mathrm{s})}<0,4\right)$

b) Netral terhadap risiko (risk neutral) $=\left(0,4<\mathrm{K}_{(\mathrm{s})}<1,2\right)$

c) Menghindari risiko (risk averse) $=\left(1,2<\mathrm{K}_{(\mathrm{s})}<2,0\right)$

\section{Pengujian Hipotesis Perilaku Petani}

Pengujian hipotesis terkait perilaku petani dilakukan berdasarkan nilai parameter penghindaran risiko $\mathrm{K}_{(\mathrm{s})}$, dengan rumusan hipotesis : 
$\mathrm{H} 0: \mathrm{K}_{(\mathrm{s})}=>0,4$ dan $<1,2$

$\mathrm{H}_{1}: \mathrm{K}_{(\mathrm{s})}=<0,4$ dan $>1,2$

\section{f. Analisis Daya Saing}

Analisis daya saing untuk menganalisis sejauh mana daya saing pada usatahani kapas, analisis ini dilakukan melalui pendekatan terhadap penggunaan sumberdaya domestik dan input tradable. Metode analisis yang digunakan adalah Policy Analysis Matrix (PAM) yang merupakan alat analisis yang dapat digunakan untuk mengetahui efisiensi ekonomi dan besarnya insentif atau dampak intervensi dalam pengusahaan berbagai aktivitas usahatani secara keseluruhan dan sistematis (Monke dan Pearson, 1995).

Pada dasarnya langkah penyusunan PAM terdiri dari empat tahapan. Berikut adalah tahapan yang dilakukan untuk menganalisa daya saing usahatani kapas pada penelitian ini;

1. Penentuan input-output fisik secara lengkap dari aktivitas ekonomi yang dianalisis;

2. Penaksiran harga bayangan (shadow price) dari input dan output;

3. Pemisahan seluruh biaya ke dalam komponen domestik dan asing, serta menghitung besarnya penerimaan; dan

4. Menghitung dan menganalisis berbagai indikator yang dihasilkan analisis PAM, sebagaimana disajikan dalam tabel analisis di bawah ini.

Penyusunan tabel PAM dilakukan dengan menggunakan struktur inputoutput di tingkat usahatani, dan pelaku tataniaga. Dengan perhitungan ini dapat diperoleh keuntungan baik finansial maupun ekonomi. Dampak kebijakan pemerintah yang diterapkan baik terhadap input, output maupun input dan output secara bersama dapat diketahui.

Tabel hubungan input dan ouput fisik dihasilkan dengan bantuan kuesioner. Sementara input yang digunakan berupa input tradable, yaitu input 
yang diperdagangkan di dalam negeri dan luar negeri serta selalu mengacu pada harga dunia, misalnya pupuk Urea, SP-36, ZA dan NPK Phonska. Sedangkan input non tradable hanya diperdagangkan secara domestik, seperti tenaga kerja yang digunakan dalam proses budidaya.

\section{Perhitungan Harga Bayangan (Harga Sosial)}

Analisis ekonomi yang dilakukan didasarkan pada harga sosial atau harga bayangan, karena harga pasar tidak mencerminkan biaya imbangan idialnya dan tidak mencerminkan korbanan yang dikeluarkan jika sumberdaya tersebut dipakai untuk kegiatan lain. Harga bayangan dilakukan dengan cara menyesuaikan terhadap penyimpangan harga yang terjadi akibat kebijakan pemerintah (subsidi, pajak, tarif, kebijakan harga) maupun distorsi pasar.

Menurut Gitinger (1986), harga bayangan adalah sebagian harga yang tejadi dalam perekonomian pada kondisi pasar persaingan sempurna dan dalam keadaan kesimbangan sosial yang sama dengan harga pasar aktual. Namun dalam kenyataannya sulit ditemukan kondisi pasar dalam kondisi keseimbangan. Jika diasumsikan bahwa perdagangan di pasar internasional adalah bersaing sempurna, maka harga bayangan untuk input dan output yang bersifat tradable dapat menggunakan harga batas atau harga bayangan (shadow price). Untuk komoditi barang ekspor atau potensial ekspor akan digunakan harga FOB (Free on Board) dan untuk barang yang diimpor akan menggunakan CIF (Cost, Insurance, and Freight). Sedangkan penggunaan Harga bayangan untuk input non tradable menggunakan biaya imbangan (opportunity cost).

\section{Harga Bayangan Output}

Harga bayangan output adalah harga output yang terjadi di pasar dunia apabila diberlakukan pasar bebas dan harga yang digunakan adalah harga batas (border price). Harga bayangan output untuk komoditas ekspor atau berpotensi ekspor digunakan harga perbatasan FOB. Sedangkan harga bayangan output untuk komoditas impor digunakan harga perbatasan CIF. Penelitian 
ini dalam menghitung harga bayangan kapas menggunakan harga CIF karena volume ekspor kapas lebih rendah dibandingkan volume impornya. Harga CIF ini akan dikonversi dengan SER dan dikurangi biaya tataniaga berupa transportasi dan handling dari pelabuhan ke lokasi penelitian.

\section{Harga Bayangan Input}

Perhitungan harga bayangan input yang tradable sama dengan perhitungan harga bayangan output, yaitu dengan menggunakan harga perbatasan (border price), yaitu komoditi ekpor menggunakan harga FOB dan komoditi impor menggunakan CIF. Sedangkan untuk perhitungan harga bayangan input yang non tradable digunakan harga domestik setelah mengeluarkan beberapa faktor domestik.

\section{a) Harga Bayangan Tenaga Kerja}

Penentuan harga bayangan tenaga kerja pada usahatani kapas di lokasi penelitian mengacu pada pada pernyataan (Monke and Pearson, 2005) bahwa harga sosial untuk tenaga kerja diestimasi dengan prinsip social opportunity cost. Penentuan upah bayangan tenaga kerja secara umum dapat di formulasikan sebagai berikut.

$\mathrm{HB}$ TK $=(100 \%-\%$ penganguran $) \times$ HA untuk TK

Keterangan :

HB : harga bayangan

HA : harga aktual

Berdasarkan data yang diperoleh, jumlah tingkat pengangguran terbuka di Provinsi Sulawesi Selatan sebesar 6,5\%, sehingga harga bayangan upah kerja tidak terdidik di lokasi penelitian sebesar 93,5\% dari upah finansialnya.

\section{b) Harga Bayangan Lahan}

Lahan merupakan faktor produksi terpenting dalam kegiatan usahatani yang termasuk kedalam input faktor domestik (non tradable). Menurut Gitinger 
(1986), penentuan harga bayangan lahan adalah dengan memakai nilai sewa yang diperhitungkan setiap musim. Sedangkan menurut Monke dan Pearson (1995), harga bayangan lahan ditentukan berdasarkan pendapatan dari tanah untuk tanaman alternatif terbaik. Dalam penelitian ini harga sosial atau bayangan lahan akan mengacu pada pandangan Gitinger (1986), sehingga harga bayangan lahan sebesar nilai sewa lahannya.

\section{c) Harga Bayangan Nilai Tukar}

Harga bayangan nilai tukar rupiah didasarkan atas perkembangan nilai tukar dollar pada tahuan 2011, menggunakan rumus yang telah diformulasikan oleh Squire dan Van Der Tak dalam Gittinger (1986) yaitu:

$$
\mathrm{SER}_{2011}=\frac{\mathrm{OER}_{2011}}{\mathrm{SCF}_{2011}}
$$

Keterangan :

$\mathrm{SER}_{2011}=$ Shadow exchange rate (nilai tukar bayangan) tahun 2011

$\mathrm{OER}_{2011}=$ Official exchange rate (nilai tukar resmi) tahun 2011

$\mathrm{SCF}_{2011}=$ Standard convertion factor (faktor konversi standar) tahun 2011

Nilai faktor konversi yang merupakan rasio nilai impor dan ekspor ditambah pajak dapat ditentukan sebagai berikut.

$$
\mathrm{SCFt}=\frac{\mathrm{Mt}+\mathrm{Xt}}{(\mathrm{Mt}+\mathrm{Tm}))+(\mathrm{Xt}-\mathrm{Tx})}
$$

Keterangan :

$\mathrm{SCFt}=$ Faktor Konversi Standar untuk tahun ke-t

$\mathrm{Xt} \quad=$ Nilai Ekspor Indonesia untuk tahun ke-t $(\mathrm{Rp})$

Mt = Nilai Impor Indonesia untuk tahun ke-t (Rp)

Txt = Penerimaan Pemerintah dari pajak ekpor untuk tahun ke-t (Rp)

$\mathrm{Tmt}=$ Penerimaan Pemerintah dari pajak impor untuk tahun ke-t $(\mathrm{Rp})$

Hasil analisis menggunakan PAM akan memberikan informasi tentang profitabilitas daya saing (keunggulan kompetitif), efisiensi ekonomik (keunggulan komparatif) suatu komoditas, dalam hal ini adalah usahatani kapas. Model Policy Analysis Matrix (PAM) yang digunakan disajikan pada Tabel 3.5. 
Tabel 3.5. Formulasi Model Policy Analysis Matrix (PAM)

\begin{tabular}{|c|c|c|c|c|}
\hline \multirow{2}{*}{ Komponen } & \multirow{2}{*}{ Penerimaan } & \multicolumn{2}{|c|}{ Biaya } & \multirow{2}{*}{ Keuntungan } \\
\hline & & Input tradable & Faktor domestik & \\
\hline Harga privat & A & B & $\mathrm{C}$ & $\mathrm{D}$ \\
\hline Harga sosial & $\mathrm{E}$ & $\mathrm{F}$ & $\mathrm{G}$ & $\mathrm{H}$ \\
\hline Dampak Divergensi & I & $\mathrm{J}$ & $\mathrm{K}$ & $\mathrm{L}$ \\
\hline \multicolumn{5}{|c|}{$\begin{array}{l}\text { Sumber : Monke and Pearson (1995) } \\
\text { Keterangan: } \\
\mathbf{I}=\mathrm{A}-\mathrm{E} ; \mathbf{J}=\mathrm{B}-\mathrm{F} ; \mathbf{K}=\mathrm{C}-\mathrm{G} ; \mathbf{L}=\mathrm{D}-\mathrm{H} ; \quad \mathbf{D}=\mathrm{A}-(\mathrm{B}+\mathrm{C}) ; \quad \mathbf{H}=\mathrm{E}-(\mathrm{F}+\mathrm{G}) ; \quad \mathbf{L}=\mathrm{I}-(\mathrm{J}+\mathrm{K}) ; \\
\mathbf{P C R}=\mathrm{C} /(\mathrm{A}-\mathrm{B}) ; \mathbf{D R C}=\mathrm{G} /(\mathrm{E}-\mathrm{F}) ; \mathbf{O T}=\mathrm{A}-\mathrm{E} ; \mathbf{N P C O}=\mathrm{A} / \mathrm{E} ; \mathbf{I T}=\mathrm{B}-\mathrm{F} ; \mathbf{N P C I}=\mathrm{B} / \mathrm{F} ; \\
\mathbf{F T}=\mathrm{C}-\mathrm{G} ; \mathbf{E P C}=(\mathrm{A}-\mathrm{B}) /(\mathrm{E}-\mathrm{F}) ; \mathbf{N T}=\mathrm{D}-\mathrm{H} ; \mathbf{P C}=\mathrm{D} / \mathrm{H} ; \mathbf{S R P}=\mathrm{L} / \mathrm{E} \\
\text { (Arti singkatan lihat uraian di bawah) }\end{array}$} \\
\hline
\end{tabular}

Berdasarkan data pada tabel PAM di atas, kemudian dapat dianalisis berbagai indikator sebagai berikut:

(1) Analisis Keuntungan privat atau Private Profitability $(\mathrm{PP}): \mathrm{D}=\mathrm{A}-(\mathrm{B}+\mathrm{C})$;

(2) Analisis Keuntungan sosial atau Social Profitability (SP) : H = E - (F+G);

(3) Efisiensi Finansial (Keunggulan Kompetitif) dengan indikator Private Cost Ratio $: \mathrm{PCR}=\mathrm{C} /(\mathrm{A}-\mathrm{B}) ;$

(4) Analisis efisiensi ekonomik atau keunggulan komparatif dengan indikator Domestic Resource Cost Ratio : DRC = G / $(\mathrm{E}-\mathrm{F})$;

(5) Output Transfer: OT = A - E;

(6) Nominal Protection Coefficient on Tradable Output: NPCO = A / E;

(7) Transfer Input : IT = B - F;

(8) Nominal Protection Coefficient on Tradable Input : NPCI = B / F;

(9) Transfer faktor: $\mathrm{FT}=\mathrm{C}-\mathrm{G}$;

(10) Effective Protection Coefficient : $\mathrm{EPC}=(\mathrm{A}-\mathrm{B}) /(\mathrm{E}-\mathrm{F})$;

(11) Transfer Netto : NT = D - H;

(12) Profitability Coefficient $\mathrm{L} \mathrm{PC}=\mathrm{D} / \mathrm{H}$; dan

(13) Subsidy Ratio to Producer: SRP = L / E. 
Kriteria berkaitan dengan daya saing diuraikan sebagai berikut :

\section{Rasio Biaya Privat (Private Cost Ratio)}

Nilai PCR menunjukkan berapa banyak sistem produksi usahatani kapas dapat menghasilkan untuk membayar semua faktor domestik yang digunakan, dan tetap dalam kondisi kompetitif. Keuntungan maksimal akan diperoleh jika sistem produksi usahatani kapas mampu meminimumkan nilai PCR. Nilai PCR merupakan kriteria keunggulan kompetitif dari usahatani kapas. Apabila nilai PCR $<1$ dan makin kecil, maka aktivitas ekonomi efisien secara finansial. Keunggulan kompetitif adalah alat untuk mengukur keuntungan privat (private profitability) dan dihitung berdasarkan harga pasar dan nilai tukar uang resmi.

\section{Rasio Biaya Sumber Daya Domestik (Domestic Resources Cost Ratio)}

Nilai DRC merupakan salah satu kriteria kemampuan usahatani kapas dalam membiayai faktor domestik pada harga bayangannya atau kriteria dari efisiensi ekonomi relatif dari suatu sistem produksi. Jika $\mathrm{DRC}<1$ dan nilainya makin kecil, berarti sistem produksi usahatani kapas makin efisien dan memiliki daya saing di pasar dunia sehingga dinilai memiliki peluang ekspor yang makin besar. Nilai DRC merupakan kriteria keunggulan komparatif dari usahatani kapas. Keunggulan komparatif adalah kemampuan suatu wilayah atau negara dalam memproduksi satu unit dari beberapa komoditas dengan biaya yang relatif lebih rendah daripada biaya imbangan sosialnya dari alternatif lainnya.

Secara umum implikasi indikator PAM sebagai berikut :

\section{Keunggulan Kompetitif}

1. $\mathrm{D}=\mathrm{A}-\mathrm{B}-\mathrm{C}$ (keuntungan privat), jika $\mathrm{D}>0$, maka sistem komoditas memperoleh keuntungan privat sehingga mampu berekspansi kecuali apabila sumberdaya terbatas atau ada alternatif komoditas lain yang menguntungkan. 
2. $\mathrm{PCR}=\mathrm{C} /(\mathrm{A}-\mathrm{B})$ (rasio biaya privat), jika $\mathrm{PCR}<1$ maka sistem komoditas mampu membiayai faktor dimasukkannya pada harga privat, dengan kata lain komoditas tersebut memiliki daya saing secara kompetitif.

\section{Keunggulan Komparatif}

1. $\mathrm{H}=\mathrm{E}-\mathrm{F}-\mathrm{G}$ (keuntungan sosial), jika $\mathrm{H}>0$, maka usahatani telah berjalan efisien sehingga bisa berekspansi.

2. $\mathrm{RC}=\mathrm{G} /(\mathrm{E}-\mathrm{F})$ (rasio biaya sumberdaya domestik), jika $\mathrm{DRC}<1$, maka sistem komoditi efisien dan memiliki keunggulan komparatif sehingga tanpa ada bantuan pemerintah masih tetap bisa berproduksi.

\section{Kebijakan Output}

1. $\mathrm{OT}=\mathrm{I}=\mathrm{A}-\mathrm{E}$ (Transfer output), menunjukkan kebijakan pemerintah yang diterapkan terhadap output yang mengakibatkan harga output berbeda dengan harga input. Jika I>0 menunjukkan besarnya insentif masyarakat terhadap produsen, artinya masyarakat membeli output dengan harga yang lebih tinggi dari harga yang seharusnya atau petani menerima harga output yang lebih tinggi daripada yang seharusnya.

2. $\mathrm{NPCO}=\mathrm{A} / \mathrm{E}$ (koefisien proteksi output nominal), digunakan untuk mengukur dampak insentif kebijakan pemerintah yang menyebabkan terjadinya perbedaan nilai output. Jika $\mathrm{NPCO}<1$ terjadi pengurangan penerimaan petani akibat adanya kebijakan.

\section{Kebijakan Input}

1. $\mathbf{J}=\mathrm{B}-\mathrm{F}$ (Transfer input domestik), menunjukkan adanya kebijakan pemerintah pada input tradable, jika $\mathrm{J}<0$ adanya subsidi pemerintah terhadap input asing sehingga petani tidak membayar penuh korbanan sosial yang seharusnya. Subsidi yang dibebankan kepada pemerintah menyebabkan keuntungan produsen secara privat. 
2. NPCI $=\mathrm{B} / \mathrm{F}$ (Koefisien proteksi input nominal), jika $\mathrm{NPCI}<1$ petani menerima subsidi atas input asing sehingga petani dapat membeli input asing dengan harga lebih rendah.

3. $\mathrm{K}=\mathrm{C}-\mathrm{G}$ (Transfer Faktor), $\mathrm{K}>0$ adanya kebijakan pemerintah yang melindungi produsen input domestik dengan pemberian subsidi.

\section{Kebijakan Input-Output}

1. $\mathrm{EPC}=(\mathrm{A}-\mathrm{B}) /(\mathrm{E}-\mathrm{F})($ Koefisien proteksi efektif $)$ merupakan indikator dampak keseluruhan kebijakan input dan output. Sejauhmana kebijakan pemerintah melindungi atau menghambat produksi. EPC >0 bahwa kebijakan pemerintah memberikan dukungan terhadap aktivitas produksi dalam negeri.

2. $\mathrm{TB}=\mathrm{I}-(\mathrm{K}-\mathrm{J})($ Transfer bersih) merupakan dampak kebijakan pemerintah secara keseluruhan terhadap penerimaan petani apakah merugikan atau sebaliknya. L>0 menunjukkan adanya tambahan surplus produsen yang disebabkan adanya kebijakan pemerintah yang diterapkan kepada input dan output.

3. $\mathrm{PC}=\mathrm{D} / \mathrm{H}$ (koefisien keuntungan) dampak insentif dari semua kebijakan output, input tradable dan domestik. PC>1 secara keseluruhan kebijakan pemerintah memberikan insentif kepada produsen. $\mathrm{PC}<1$ kebijakan pemerintah mengakibatkan keuntungan yang diterima produsen lebih kecil dibandingkan tanpa kebijakan.

4. $\mathrm{SRP}=\mathrm{L} / \mathrm{E}$ (Nilai rasio Subsidi bagi Produsen) mengidentifikasi akibat kebijakan pemerintah yang menunjukkan penambahan atau pengurangan penerimaan. $\mathrm{SRP}<0$, produsen mengeluarkan biaya lebih besar dari biaya sosial untuk berproduksi.

\section{Pengujian Hipotesis Daya Saing}

\section{Pengujian Keunggulan Kompetitif}

Pengujian hipotesis berkaitan keunggulan kompetitif (competitive advantange) usahatani kapas rakyat dilakukan dengan melihat nilai PCR, dengan rumusan hipotesis : 
H0 : PCR $<1$

$\mathrm{H} 1: \mathrm{PCR} \geq 1$

Pengujian hipotesis dilakukan dengan menggunakan rumus :

$\mathrm{PCR}=\frac{\text { Harga privat faktor domestik }}{\text { Penerimaan Privat }- \text { Harga privat input tradable }}$

Jika PCR $<1$ maka artinya sistem produksi komoditas mampu membiayai faktor domestiknya pada harga privat, dengan kata lain komoditas tersebut memiliki daya saing secara kompetitif.

\section{Pengujian Keunggulan Komparatif}

Uji hipotesis keunggulan komparatif (comparative advantange) usahatani kapas rakyat dilakukan dengan melihat nilai DRC, dengan rumusan hipotesis :

$$
\begin{aligned}
& \mathrm{H}_{0}: \text { DRC }<1 \\
& \mathrm{H}_{1}: \mathrm{DRC} \geq 1
\end{aligned}
$$

Pengujian hipotesis dilakukan dengan menggunakan rumus :

$$
\text { DRC }=\frac{\text { Harga sosial faktor domestik }}{\text { Penerimaan sosial }- \text { Harga sosial input tradable }}
$$

Jika DRC $<1$ maka sistem komoditas mampu membiayai faktor domestiknya pada harga sosial dan memiliki daya saing tinggi (keunggulan komparatif), karena mampu berkembang tanpa bantuan pemerintah serta memiliki peluang ekspor yang lebih besar. Sebaliknya jika DRC>1, maka sistem komoditi tidak mampu berkembang tanpa bantuan atau intervensi pemerintah, sehingga memboroskan sumberdaya domestik yang langkah.

\section{g. Analisis Korelasi}

Analisis korelasi dilakukan untuk mengetahui ada atau tidaknya hubungan antara efisiensi dan perilaku petani serta efisiensi dan daya saing. Dalam penelitian ini analisis menggunakan program SPSS 18, alat analisis yang digunakan adalah korelasi Kendall's tau (r) dan korelasi Spearman (p). 
Berdasarkan hasil analisis korelasi didapat koefisien korelasi yang digunakan untuk mengetahui hubungan dan arah hubungan, sedangkan signifikansi untuk mengetahui apakah hubungan yang terjadi berarti atau tidak. Untuk mengetahui keeratan hubungan maka dapat dilihat pada besarnya koefisien korelasi dengan pedoman jika koefisien semakin mendekati 1 atau -1 maka hubungan erat atau kuat, sedangkan jika koefisien semakin mendekati 0 , maka hubungan sangat lemah. Untuk mengetahui arah hubungan maka dapat dilihat pada tanda nilai koefisien yaitu positif atau negatif, jika positif berarti terdapat hubungan yang positif dan sebaliknya. Sedangkan untuk mengetahui apakah hubungan berarti atau tidak maka dilakukan pengujian signifikansi (Priyatno, 2009).

Pengujian hubungan antara Efisiensi dan Perilaku

Uji hipotesis hubungan antara Efisiensi dan Perilaku Petani dilakukan dengan melihat signifikansi, dengan rumusan hipotesis :

H0 : signifikansi > 0,05 artinya tidak ada hubungan antara efisiensi dan perilaku $\mathrm{H}_{1}$ : signifikansi $\leq 0,05$ artinya terdapat hubungan antara efisiensi dan perilaku

\section{Pengujian hubungan antara Efisiensi dan Daya Saing}

Sementara untuk uji hipotesis hubungan antara Efisiensi dan Daya Saing dilakukan dengan melihat signifikansi, dengan rumusan hipotesis :

$\mathrm{H} 0$ : signifikansi $>0,05$ artinya tidak ada hubungan antara efisiensi dan daya saing $\mathrm{H}_{1}$ : signifikansi $\leq 0,05$ artinya terdapat hubungan antara efisiensi dan daya saing 


\section{DESKRIPSI WILAYAH DAN KARATERISTIK PETANI KAPAS DI SULAWESI SELATAN}

\subsection{Deskripsi Wilayah}

Provinsi Sulawesi Selatan (Sulsel) merupakan salah satu provinsi di Kepulauan Sulawesi dengan batas geografis, yaitu : Provinsi Sulawesi Barat di sebelah Utara, Teluk Bone di sebelah Timur, Selat Makassar di sebelah Barat, dan Laut Flores di sebelah Selatan. Secara geografis, wilayah ini terletak antara $0^{\circ} 12^{\prime}$ sampai dengan $8^{\circ}$ Lintang Selatan (LS) dan $116^{\circ} 48^{\prime}$ sampai dengan $112^{\circ} 36^{\prime}$ Bujur Timur (BT).

Wilayah Provinsi Sulsel mempunyai luas 46.717,48 $\mathrm{km}^{2}$ dengan jumlah penduduk tahun 2009 sebanyak $\pm 8,3$ juta jiwa dan terdiri dari 24 kabupaten/kota yaitu 21 kabupaten dan 3 kotamadya yang memiliki 4 suku daerah yaitu suku Bugis, Makassar, Mandar dan Toraja (BPS, 2010).

Terdapat empat kategori dimensi sumber daya alam Provinsi Sulsel, yaitu; dataran rendah yang meliputi hampir semua kabupaten/kota, dataran tinggi yang meliputi Kabupaten Luwu, Tana Toraja, Luwu Utara, Enrekang, Sinjai, Gowa, Bone, dan sebagian di wilayah Sidrap, Wajo, Pinrang, Maros, Pangkep dan Parepare, Perairan pantai yang meliputi kabupaten/kota yang terbentang di pesisir Pantai Timur dan Pantai Barat, dan Laut Dalam yang meliputi Selat Makassar, Teluk Bone, dan Laut Selayar. Sementara berdasarkan pemanfaatan lahannya, Sulsel memiliki luas wilayah yang mencakup kawasan hutan $(57,59 \%)$, sawah $(9,01 \%)$, rawa $(1,65 \%)$, danau, tambak $(2,84 \%)$, perikanan $(1,07 \%)$, perkebunan $(9,85 \%)$, lain-lain $(8,74 \%)$. 
Tabel. 4.1. Luas Wilayah Provinsi Sulawesi Selatan dirinci Menurut Kabupaten

\begin{tabular}{|c|c|c|c|}
\hline \multirow{2}{*}{ Nama Kabuapten/Kota } & \multirow{2}{*}{ Ibukota } & Luas & $\begin{array}{c}\text { Jarak ke Ibukota } \\
\text { Provinsi }\end{array}$ \\
\hline & & $\left(\mathrm{Km}^{2}\right)$ & $(\mathrm{Km})$ \\
\hline Kabupaten Bantaeng & Bantaeng & 396 & 123 \\
\hline Kabupaten Barru & Barru & 1.175 & 102 \\
\hline Kabupaten Bone & Watampone & 4.559 & 174 \\
\hline Kabupaten Bulukumba & Bulukumba & 1.155 & 153 \\
\hline Kabupaten Enrekang & Enrekang & 1.786 & 236 \\
\hline Kabupaten Gowa & Sungguminasa & 1.883 & 11 \\
\hline Kabupaten Jeneponto & Bontosunggu & 903 & 91 \\
\hline Kabupaten Luwu & Belopa & 3.248 & 326 \\
\hline Kabupaten Luwu Timur & Malili & 6.945 & 565 \\
\hline Kabupaten Luwu Utara & Masamba & 7.503 & 440 \\
\hline Kota Makassar & Makasar & 176 & 0 \\
\hline Kabupaten Maros & Maros & 1.619 & 30 \\
\hline Kota Palopo & Palopo & 248 & 376 \\
\hline Kabupaten Pangkep & Pangkajene & 1.112 & 51 \\
\hline Kota Pare-Pare & Pare-Pare & 99 & 155 \\
\hline Kabupaten Pinrang & Pinrang & 1.961 & 182 \\
\hline Kabupaten Selayar & Benteng & 904 & 263 \\
\hline Kabupaten Sidrap & Sidenreng & 1.883 & 188 \\
\hline Kabupaten Sinjai & Sinjai & 820 & 220 \\
\hline Kabupaten Soppeng & Watansoppeng & 1.359 & 192 \\
\hline Kabupaten Takalar & Pattalasang & 567 & 45 \\
\hline Kabupaten Tanatoraja & Makale & 3.011 & 320 \\
\hline Kabupaten Toraja Utara & Rantepao & 1.151 & 328 \\
\hline Kabupaten Wajo & Sengkang & 2.506 & 242 \\
\hline
\end{tabular}

Sumber : Sulawesi Selatan Dalam Angka, BPS, 2010

Potensi sumber daya iklim dan lahan Provinsi Sulsel cukup mendukung berbagai komoditas pertanian, termasuk kapas. Karakteristik iklim dan lahan yang berbeda, merupakan kekayaan yang dapat dimanfaatkan untuk menunjang pembangunan pertanian. Menurut Herniwati dan Kadir (2009), berdasarkan kesamaan relatif zona iklimnya, Sulsel dikelompokkan menjadi 3 bagian yaitu sektor Barat, Timur dan Peralihan. Sedangkan berdasarkan klasifikasi Oldemen dibagi atas 13 tipe iklim yaitu A, B1, B2, C1, C2, C3, D1, D2, D3, E1, E2, E3 dan E4. Potensi sumberdaya lahan di Sulsel didominasi oleh pertanian semusim yang diusahakan pada sebagian besar wilayah yang ada. Pola tanam beragam yang diterapkan petani didasarkan pada kondisi curah hujan, yang bila dihubungkan dengan tipologi lahan, hal ini akan makin memperkaya keanekaragaman 
pemanfaatan sumberdaya alam. Dengan demikian pengembangan komoditas yang didasarkan pada tipe iklim, bentuk wilayah dan tanah diharapkan dapat meningkatkan efisiensi usaha tani dan memacu perekonomian daerah.

Provinsi Sulsel saat ini merupakan salah satu wilayah pengembangan kapas dengan areal terluas. Hasil survey perwilayahan komoditas kapas di Sulsel (Sahid, 1995) menunjukkan potensi pengembangan kapas di lahan kering seluas 68.891 ha dengan sentra pengembangan di Kabupaten Jeneponto, Gowa, Bone, Bulukumba, Bantaeng dan Takalar. Di lahan sawah seluas 165.914 ha dengan sentra Kabupaten Bone, Soppeng, Bulukumba, Wajo dan Takalar. Di luar wilayah kabupaten tersebut dapat juga dikembangkan kapas tetapi bukan sebagai tanaman andalan.

Variasi hujan di lahan tadah hujan di Sulsel sangat tinggi, sehingga diperlukan penetapan waktu tanam. Waktu tanam ditetapkan berdasarkan analisis curah hujan lebih dari 20 tahun yang terkumpul dari 46 stasiun pengamatan hujan yang tersebar di daerah-daerah pengembangan kapas. Berdasarkan hasil analisis yang pernah dilakukan, minggu tanam paling lambat (MPL) di Jeneponto, Takalar dan sebagian Gowa berkisar minggu I-IV Desember. Sedangkan di Kabupaten Soppeng dan berkisar minggu III-Februari sampai minggu III-Maret. Di Bone dan Bulukumba, MPL berkisar minggu III-Maret sampai minggu III-April (Riajaya et $a l, 2001)$.

\subsection{Kebijakan Pengembangan Kapas}

Sasaran nasional dari kegiatan penanaman tanaman kapas adalah meningkatkan produksi dan produktivitas tanaman kapas agar kontribusi serat kapas terhadap industri TPT dalam negeri dapat meningkat. Terkait dengan hal tersebut, maka sejak tahun 2007 pemerintah telah memfasilitasi upaya akselerasi peningkatan areal dan produksi tanaman kapas, melalui dana APBN dan tugas pembantuan (TP) provinsi berupa penyediaan benih bermutu (100\%) dan pemberian bantuan sarana produksi (25\%), pendampingan tenaga teknis lapangan dan pelatihan petani. 
Tujuan dari kegiatan penanaman tanaman kapas diarahkan pada :

1. Meningkatkan produksi, produktivitas dan mutu kapas berbiji melalui penanaman kapas sesuai baku teknis yang benar sehingga mampu meningkatkan kontribusi serat kapas pada industri TPT dalam negeri.

2. Mengoptimalkan unit pengolahan (ginnery) yang ada sesuai kapasitas.

3. Memperluas kesempatan kerja dan peluang usaha di wilayah pengembangan sehingga meningkatkan kesejahteraan petani.

Terdapat dua pendekatan utama yang diakukan dalam pelaksanaan penanaman kapas di Sulsel, yakni melalui : Manajemen kelompok, dengan tujuan untuk meningkatkan efisiensi usaha, mempermudah akses pembinaan, akses memperoleh informasi (perkembangan teknologi, pasar, dll.) bagi petani, serta saling memperkuat posisi tawar petani dengan mitra usahanya yaitu perusahaan pengelola/mitra. Pendekatan selanjutnya dengan melakukan Kerjasama kemitraan antara petani dengan perusahaan pengelola setempat yang telah ditetapkan berdasarkan Surat Keputusan Direktur Jenderal Perkebunan.

\subsection{Karakteristik Petani}

Karakterisitik petani merujuk pada integrasi dari sifat-sifat individual yang melekat pada diri petani yang berada di lokasi studi. Karakteristik seperti umur petani, pengalaman usahatani, tingkat pendidikan, jumlah anggota/tanggungan rumah tangga dan lama bergabung dalam kelompok tani menjadi faktor penentu yang mempengaruhi berbagai keputusan dalam aktivitas usahatani kapas. Gambaran mengenai karakteristik petani kapas di lokasi penelitian dapat dilihat pada Tabel 4.2 dan uraian berikut.

Tabel 4.2. Deskripsi Statistik Petani Kapas di Sulawesi Selatan

\begin{tabular}{lrcrr}
\hline Variable & Mean & Std.Dev & Minimum & Maksimum \\
\hline Umur (thn) & 45 & 10 & 19 & 70 \\
Pengalaman Usahatani (thn) & 4 & 2 & 2 & 10 \\
Pendidikan (thn) & 8 & 3 & 4 & 19 \\
Jumlah anggota keluarga (org) & 4 & 1 & 2 & 8 \\
Lama dalam KT (thn) & 4 & 1 & 2 & 10 \\
\hline Sumber : Analisis Data Primer, 2012 & & & &
\end{tabular}




\section{a. Umur Petani}

Sebaran umur petani kapas secara keseluruhan pada lokasi penelitian, berkisar 19 - 70 tahun dengan rata-rata umur 45 tahun. Jika mengacu pada klasifikasi umur menurut Badan Pusat Statistik (BPS), petani kapas di lokasi penelitian termasuk pada kelompok usia produktif atau aktif secara ekonomis (15 - 64 thn). Hal ini berarti bahwa secara fisik petani kapas cukup potensial dan sangat membantu sebagai sumber tenaga kerja aktivitas usahatani kapas.

Usahatani kapas di lokasi penelitian sebagian besar dilakukan oleh petani yang berusia kurang dari 50 tahun (72,67\%). Sebanyak 27,33\% lainnya berusia 51 tahun ke atas. Umur tertua dari seluruh petani yang menjadi sampel dalam penelitian ini yaitu 70 tahun dan yang termuda berusia 19 tahun.

Tabel 4.3 Sebaran Petani Responden Berdasarkan Kelompok Umur

\begin{tabular}{ccc}
\hline Kelompok Umur (th) & Jumlah petani & Persentase $(\%)$ \\
\hline$<21$ & 2 & 1.33 \\
$21-30$ & 12 & 8.00 \\
$31-40$ & 40 & 26,67 \\
$41-50$ & 55 & 36.67 \\
$51-60$ & 35 & 23,33 \\
$61-70$ & 6 & 4.00 \\
\hline Jumlah & 150 & 100.00 \\
\hline
\end{tabular}

Sumber : Data Primer Diolah, 2012

\section{b. Pengalamaan usahatani.}

Pengalaman usahatani kapas yang dimiliki petani responden sebagian besar $(64 \%)$ berada pada kisaran 4-7 tahun. Semakin lama pengalaman usahatani yang dimiliki petani, diharapkan makin meningkatkan kemampuan petani, karena petani semakin banyak belajar dari usahatani sebelumnya untuk kemudian digunakan sebagai pembelajaran usahatani musim berikutnya. Pada penelitian ini sekitar $4,67 \%$ petani memiliki pengalaman 8 tahun ke atas, dan tersisa $31,33 \%$ lainnya dengan pengalaman 3 tahun atau kurang. 
Tabel 4.4. Sebaran Petani Responden Berdasarkan Pengalaman Usahatani

\begin{tabular}{ccc}
\hline Pengalaman usahatani kapas (thn) & Jumlah Petani (org) & Persentase (\%) \\
\hline$\leq 3$ & 47 & 31,33 \\
$4-7$ & 96 & 64,00 \\
$\geq 8$ & 7 & 4,67 \\
\hline Jumlah & 150 & 100,00
\end{tabular}

Sumber : Data Primer Diolah, 2012

\section{c. Pendidikan Formal}

Pendidikan formal merupakan salah satu karakteristik petani yang mempengaruhi kemampuan petani dalam menerapkan teknologi baru pada usahataninya. Pendidikan juga umumnya berperan dalam kehidupan petani untuk mengambil keputusan. Berdasarkan tingkat pendidikan formal yang dicapai sebagian besar petani kapas berpendidikan setara sekolah dasar yaitu sebesar $54,67 \%$. Sedangkan untuk petani yang berpendidikan setingkat SLTP terdapat $14,67 \%$ dan untuk SLTA sebanyak 28,00\%. Walaupun demikian, pada umumnya petani memiliki pendidikan non-formal yang diterima pada berbagai kegiatan penyuluhan yang tergabung dalam wadah kelompok tani. Sehingga merupakan faktor pendorong yang positif bagi kelancaran penerapan teknologi rekomendasi pada usahatani yang dikelolanya.

Tabel 4.5. Sebaran Petani Responden Berdasarkan Tingkat Pendidikan Formal

\begin{tabular}{lrr}
\hline Pendidikan Formal & Jumlah Petani & Persentase (\%) \\
\hline$\leq$ SD $(6$ thn $)$ & 82 & 54,67 \\
SLTP $(7-9$ thn $)$ & 22 & 14,67 \\
SLTA (10-12 thn $)$ & 42 & 28,00 \\
D3/S1 (>12 thn $)$ & 4 & 2,67 \\
\hline \multicolumn{1}{c}{ Jumlah } & 150 & 100,00 \\
\hline
\end{tabular}

Sumber : Data Primer Diolah, 2012

\section{d. Jumlah Anggota Rumah Tangga}

Jumlah anggota keluarga berpengaruh terhadap motivasi berusahatani sebagai refleksi yang menyangkut kebutuhan hidup keluarga. Hasil penelitian lapang memberi gambaran bahwa dilihat dari jumlah anggota keluarga (termasuk KK), terdapat $60 \%$ petani memiliki tanggungan sebanyak 4-6 orang, 
$36 \%$ memiliki tanggungan keluarga sebanyak 1-3 orang dan sisanya 4\%, memiliki anggota keluarga 7 atau lebih. Gambaran selengkapnya dapat dilihat pada Tabel 4.6.

Tabel 4.6. Sebaran Petani Responden Berdasarkan Jumlah Anggota Keluarga

\begin{tabular}{ccc}
\hline Pengalaman usahatani kapas (thn) & Jumlah Petani (org) & Persentase (\%) \\
\hline$\leq 3$ & 54 & 36,00 \\
$4-6$ & 90 & 60,00 \\
$\geq 7$ & 6 & 4,00 \\
\hline Jumlah & 150 & 100,00
\end{tabular}

Sumber : Data Primer Diolah, 2012

\section{e. Lama Dalam Kelompok Tani}

Lama dalam kelompok tani merupakan salah satu karakteristik petani yang mempengaruhi kemampuan petani dalam menerapkan teknologi baru. Melalui wadah kelompok tani diharapkan akan terjalin kerjasama antar anggota kelompok tani, baik dalam proses belajar maupun dalam proses produksi. Lama petani bergabung dalam kelompok tani kapas di lokasi penelitian maksimum 10 tahun dan yang paling minimum selama 2 tahun, rata-rata petani responden telah bergabung selama 5 tahun dalam kelompok usahatani tanaman kapas. Terdapat 48,67\% petani yang telah bergabung dalam kelompok tani antara 4-7 tahun, dan yang terbesar, yakni 49,33\% baru bergabung selama 2 tahun.

Tabel 4.7. Sebaran Petani Responden Berdasarkan Lama Bergabung Dalam Kelompok Tani

\begin{tabular}{ccc}
\hline $\begin{array}{c}\text { Lama Bergabung Dalam } \\
\text { Kelompok Tani (thn) }\end{array}$ & Jumlah Petani & Persentase (\%) \\
\hline$\leq 3$ & 74 & 49,33 \\
$4-7$ & 73 & 48,67 \\
$>7$ & 3 & 2,00 \\
\hline Jumlah & 150 & 100,00 \\
\hline
\end{tabular}

Sumber : Data Primer Diolah, 2012 


\subsection{Penerapan Teknologi Usahatani Kapas di Sulsel}

Kontribusi usahatani kapas dalam meningkatkan pendapatan petani sangat bergantung pada pencapaian tingkat produktivitas yang tinggi dan efektifitas tingkat pengelolaan di lapangan. Hal ini umumnya dapat dicapai apabila teknologi sistem produksi tanaman cukup tersedia dan dapat diaplikasikan pada kondisi lingkungan yang sesuai, jika terdapat hambatan dalam penerapan sistem produksi yang dimaksud, maka perlu adanya penyesuaian melalui serangkaian tindakan perbaikan yang masih mungkin untuk dilakukan dengan mengacu pada rancangan program akselerasi pengembangan kapas di Sulsel. Berdasarkan hasil pengamatan di lapangan, kinerja penerapan teknologi sistem produksi tanaman kapas pada musim tanam 2011 dapat diuraikan sebagai berikut.

\section{a. Pola Tanam Tanaman Kapas.}

Pola tanam pada lahan usahatani sangat ditentukan oleh curah hujan yang merupakan faktor iklim paling berpengaruh dalam aktivitas pertanian. Dalam penerapannya usahatani kapas di Sulsel kebanyakan diusahakan pada lahan sawah tadah hujan atau lahan kering yang sangat bergantung pada tingkat ketersediaan air. Pola penanamannya dilakukan dua kali setahun, memanfaatkan ketersediaan curah hujan. Pada lahan sawah, penanaman kapas dilakukan setelah tanaman padi, sedangkan pada lahan kering penanamannya setelah panen jagung yang monokultur. Penanaman kapas dilakukan secara intercropping, yang umumnya dengan tanaman jagung dan atau kacang-kacangan. Luasan tanaman jagung dan kacangan-kacangan sekitar 10-25\% dari luas garapan. Penanaman sistem tumpasari ini menerapkan pola strip cropping, yaitu 3-4 baris kapas dan 1 baris jagung/kacang-kacangan. Umumnya sistem tumpangsari dilakukan, karena petani masih mengharapkan adanya distribusi pendapatan dan mengurangi risiko kegagalan.

\section{b. Pengolahan Tanah}

Persiapan lahan pada usahatani kapas di lokasi penelitian sangat penting artinya dalam menentukan tingkat pengelolaan tanaman. Pengolahan 
lahan pada awal persiapan media pertumbuhan tanaman kapas dilakukan dengan sistem tanpa olah tanah (TOT). Sistem ini dilakukan melalui penyemprotan lahan dengan herbisida yang telah disiapkan dalam paket akselerasi. Penyemprotan dengan herbisida umumnya dilakukan dengan pertimbangan bahwa lahan yang sebelumnya ditanami tanaman padi masih cukup memadai untuk dilanjutkan penggunaannya untuk tanaman lain, salah satunya tanaman kapas. Penerapan sistem TOT, secara teknis akan mengurangi jumlah penggunaan tenaga kerja serta menghemat waktu dibandingkan kalau dilakukan olah tanah sempurna (OTS).

\section{c. Penanaman Benih}

Penanaman benih dilakukan dari akhir bulan Maret hingga akhir Mei, tergantung pada kesiapan lahan dan curah hujan. Sebagian penanaman ada yang tidak mengikuti jadwal tanam, karena hujan belum turun dan atau panen jagung yang terlambat dilakukan. Benih yang digunakan merupakan jenis hibrida unggul bernama HSC 138, yang ditanam dengan beberapa variasi jarak tanam, sekitar 75-100 cm untuk antar barisan dan sekitar 25-40 cm untuk jarak dalam barisan. Jenis dan jumlah benih yang dipakai berupa paket sebanyak 4-6 kg/ha. Benih HSC 138 yang digunakan merupakan benih unggul sesuai standar kebutuhan program, sehingga jumlah biji setiap lubang cukup 1-2 biji/lubang, beberapa petani masih melakukan aplikasi menggunakan 2-3 biji/lubang sebagai antipasi jika daya tumbuh benih tidak sesuai yang diharapkan serta menghindari kegiatan penyulaman yang akan berdampak pada peningkatan penggunaan waktu dan jumlah tenaga kerja. Jika mesti melakukan penyulaman, biasanya petani melakukannya pada umur 14 hari setelah tanam (HST).

\section{d. Pemeliharaan Tanaman}

Kegiatan pemeliharaan pada pertanaman kapas merupakan salah satu faktor yang menentukan tingkat pencapaian produksi dan keberhasilan usahatani kapas. Secara teknis kegiatan ini meliputi beberapa upaya berikut. 


\section{Penyiangan}

Kegiatan ini merupakan salah satu upaya pengendalian gulma yang keberadaanya menjadi pesaing tanaman dalam memanfaatkan unsur hara dan faktor tumbuh lainnya, sehingga keberadaannya harus dikendalikan. Aktivitas penyiangan petani kapas di Sulsel umumnya menggunakan herbisida sebagaimana dilakukan pada persiapan lahan sistem TOT. Tujuannya selain untuk mengurangi curahan tenaga kerja juga mengharapkan perbaikan struktur tanah dari hasil pelapukan gulma. Jenis herbisida yang digunakan dalam usahatani kapas adalah Bionasa dan Polaris. Pada usahatani kapas, herbisida sudah merupakan paket bantuan yang pengadaannya disediakan oleh pihak mitra dan selebihnya dengan pembelian atau mengadakan secara swadaya. Jumlah herbisida yang disediakan dalam paket bantuan akselerasi sebanyak 4 liter per hektar. Aplikasi herbisida untuk penyiangan dilakukan saat tanaman berumur 30-40 hari setelah tanam. Hal ini dimaksudkan untuk menekan pertumbuhan gulma, karena pada saat umur tersebut tanaman kapas sudah semakin tinggi sehingga lebih unggul dalam persaingan mendapatkan unsur hara, air dan cahaya untuk pertumbuhannya.

\section{Pemupukan}

Jenis dan bantuan pupuk telah ditentukan sebelumnya berdasarkan Rencana Definif Kebutuhan Kelompok (RDKK) yang jumlahnya 25\% dari kebutuhan pupuk per hektarnya*. Pupuk yang disiapkan dalam paket bantuan terdiri dari Urea, NPK, SP-36 dan ZA, masing-masing disediakan sebesar $50 \mathrm{~kg}$ per hektar. Aplikasi pemberian pupuk yang dianjurkan dilakukan dua kali selama proses pertumbuhan tanaman yaitu pada saat tanaman berumur sekitar 7-14 HST, sedangkan pupuk susulan pada saat tanaman sudah berumur sekitar 40-45 HST. Namun karena aktivitas pemupukan sangat bergantung pada ketersediaan air, beberapa petani terpaksa melakukan pemupukan lebih lambat

*) Kebutuhan pupuk untuk tanaman kapas sesuai rekomendasi pada program akselerasi pengembangan kapas adalah; Urea $100 \mathrm{~kg} / \mathrm{ha}$, ZA $50 \mathrm{~kg} / \mathrm{ha}$, SP-36 $100 \mathrm{~kg} / \mathrm{ha}$ dan $\mathrm{KCl} 100$ $\mathrm{kg} / \mathrm{ha}$. (Ditjembun, 2012). 
dari yang ditentukan menunggu adanya hujan. Selain itu adanya keterlambatan penerimaan pupuk dari perusahaan mitra, menyebabkan beberapa petani melakukan pemupukan tanaman sekaligus yakni menggabungkan jumlah dosis yang akan diaplikasikan pada tahap I dan II.

\section{Pengendalian Organisme Pengganggu.}

Pengendalian organisme pengganggu tanaman (OPT) dilakukan saat adanya serangan. Melalui program akselerasi pengembangan kapas di Sulsel disiapkan petisida jenis insektisida untuk mengantisipasi jika terjadi serangan, jumlah insektisida yang disiapkan adalah 100 gr/ha. Jumlah ini ditetapkan dengan harapan terjadinya pengurangan aplikasi penyemprotan karena jenis kapas baru HSC 138 yang merupakan benih unggul dan memiliki ketahanan terhadap serangan ulat boll. Berkurangnya aplikasi penyemprotan diharapkan dapat menekan biaya produksi untuk pengadaan pestisida yang harganya masih cukup mahal. 


\section{ANALISIS FUNGSI PRODUKSI DAN EFISIENSI PRODUKSI}

\subsection{Analisis Fungsi Produksi Stochastic Frontier}

Pendugaan hasil pada studi ini menggunakan model stochastic frontier Cobb-Douglas dengan metode pendugaan Maximum Likelihood Estimated (MLE). Nilai MLE diperoleh menggunakan Program Frontier 4.1. Tahapan awal pada program Frontier versi 4.1 menghasilkan nilai berdasarkan metode Ordinary Least Square (OLS) untuk menduga semua parameter nilai dugaan yang menggambarkan tingkat kinerja rata-rata (best fit) dari produksi petani pada tingkat teknologi yang ada. Tahap selanjutnya menggunakan metode MLE untuk menduga keseluruhan parameter faktor produksi, intersep dan varians dari kedua komponen kesalahan $v_{i}$ dan $u_{i}$. Metode MLE menggambarkan kinerja terbaik (best practice) dari perilaku petani dalam proses produksi.

Faktor-faktor produksi (variabel independen) awal yang diduga akan mempengaruhi produksi kapas yaitu luas lahan, jumlah penggunaan benih, jumlah penggunaan pupuk Urea, jumlah penggunaan pupuk NPK (Phonska), jumlah penggunaan pupuk SP-36, jumlah pemakaian insektisida, jumlah penyemprotan herbisida, dan jumlah pemanfaatan tenaga kerja. Hal ini didasarkan pada kondisi pertanaman kapas yang ada di lapangan saat dilakukan pengambilan data secara langsung.

Hasil estimasi fungsi produksi dengan pendekatan stochastic frontier pada usahatani kapas di Sulsel memberikan beberapa gambaran pokok baik berupa tanda, besaran, maupun tingkat signifikansi dari parameter yang diestimasi sebagaimana ditunjukkan pada Tabel 5.1. 
Tabel 5.1. Fungsi Produksi Stochastic Frontier Usahatani Kapas dengan Metode MLE

\begin{tabular}{|c|c|c|c|c|}
\hline Variabel & Parameter & $\begin{array}{c}\text { Tanda } \\
\text { Harapan }\end{array}$ & Koefisien & T-Rasio \\
\hline Intersep & $\beta 0$ & $+/-$ & $2,321^{\text {**** }}$ & 3,168 \\
\hline LnLh & $\beta 1$ & + & $0,476^{* * * *}$ & 4,226 \\
\hline LnBnh & $\beta 2$ & + & $-0,097$ & $-0,964$ \\
\hline LnUr & $\beta 3$ & + & $0,229^{\text {**** }}$ & 4,983 \\
\hline LnNpk & $\beta 4$ & + & 0,023 & 0,278 \\
\hline LnZa & $\beta 5$ & + & $-0,040$ & $-0,625$ \\
\hline LnSp & $\beta 6$ & + & $0,111^{*}$ & 1,539 \\
\hline LnIns & $\beta 7$ & + & $0,172^{* * *}$ & 6,383 \\
\hline LnHer & $\beta 8$ & + & $0,102^{\text {**** }}$ & 3,833 \\
\hline LnTk & $\beta 9$ & + & $0,643^{\text {*** }}$ & 5,061 \\
\hline sigma-squared & $\sigma^{2}$ & & $0,042^{* * * *}$ & 7,079 \\
\hline gamma & $\gamma$ & & $0,999^{\text {*** }}$ & 738,040 \\
\hline Log likelihood function & LLF & & 32,812 & \\
\hline LR Test of the one-side error & & & 9,524 & \\
\hline
\end{tabular}

Sumber : Analisis Data Primer, 2012.

Keterangan :

$\left.{ }^{* * * *}\right)=$ Signifikan pada taraf $\alpha=1 \% \quad \mathrm{t}_{\text {Tabel } \alpha} 1 \%=2,576$

*) $=$ Signifikan pada taraf $\alpha=10 \% \quad \mathrm{t}_{\text {Tabel } \alpha} 10 \%=1,282$

Berdasarkan hasil estimasi fungsi produksi stochastic frontier, model ini memiliki nilai parameter $\gamma$ sebesar 0,999. Parameter dugaan $\gamma$ merupakan rasio antara deviasi inefisiensi teknis $\left(u_{i}\right)$ terhadap deviasi yang mungkin disebabkan oleh faktor acak ( $\left.v_{i}\right)$. Secara statistik, nilai 0,999, berarti bahwa sebesar 99,9\% dari error yang ada di dalam fungsi produksi menggambarkan efisiensi teknis petani atau disebabkan karena adanya inefisiensi teknis, yang berarti pula error yang ada bukan disebabkan oleh variabel kesalahan acak atau efek-efek stochastic seperti pengaruh cuaca, serangan hama penyakit serta kesalahan pemodelan. Hal ini menjelaskan bahwa semua variasi dalam keluaran dari produksi frontier dapat dianggap sebagai akibat dari tingkat pencapaian efisiensi teknis yang berkaitan dengan persoalan manajerial di dalam pengelolaan usahatani.

Berdasarkan gambaran hasil terhadap variabel independen yang digunakan dalam model fungsi produksi, beberapa variabel yang berpengaruh positif dan signifikan yaitu luas lahan (Lh), jumlah pupuk Urea (Ur), jumlah 
pupuk SP-36 (Sp) pemakaian insektisida (Ins), penyemprotan herbisida (Her) dan pemanfaatan tenaga kerja (Tk).

\section{a. Lahan}

Berdasarkan Tabel 5.1 diperoleh hasil yang menunjukkan bahwa variabel lahan berpengaruh positif dan signifikan pada taraf kepercayaan $99 \%$ terhadap produksi pada usahatani kapas rakyat di Sulsel. Hal ini menunjukkan bahwa tingkat produksi berbanding lurus dengan luas lahan. Nilai koefisien variabel lahan pada model menunjukkan elastisitas variabel lahan terhadap produksi kapas sebesar 0,476. Hal ini berarti peningkatan luas lahan sebesar 1\% akan mengakibatkan peningkatan produksi kapas sebesar 0,476\%, cateris paribus. Kondisi ini menjelaskan bahwa luas lahan usahatani kapas berkorelasi positif terhadap luas panen tanaman kapas sehingga berpengaruh terhadap peningkatan produksi kapas.

Hubungan positif serta pengaruh variabel lahan yang besar terhadap produksi kapas dapat menjelaskan bahwa ekstensifikasi merupakan salah satu cara untuk meningkatkan produksi kapas di lokasi penelitian. Upaya ekstensifikasi masih memungkinkan dilakukan karena masih terdapat sumber daya lahan yang dapat dioptmalkan untuk penanaman kapas.

\section{b. Benih}

Variabel jumlah benih berpengaruh negatif dan tidak signifikan terhadap produksi pada usahatani kapas rakyat di Sulsel. Elastisitas produksi dari variabel benih bernilai negatif 0,097 . Hal ini berarti bahwa penambahan jumlah benih sebesar $1 \%$ akan menurunkan capaian produksi sebesar 0,097\%, cateris paribus, dengan kata lain jumlah benih yang digunakan telah melampaui jumlah penggunaan maksimum. Kondisi ini dapat dijelaskan berdasarkan gambaran pertanaman di lapangan yang bersifat tumpangsari, yang penggunaan benihnya seharusnya tidak sebanyak benih yang digunakan pada sistem tanam monokultur. Jumlah benih yang disiapkan sebenarnya telah memperhitungkan adanya kegiatan penyulaman, tapi yang terjadi untuk mengaplikasikan seluruh paket 
yang diberikan, benih terpaksa ditanam dengan jarak tanam yang rapat disertai peningkatan jumlah biji per lubang tanam. Secara agronomis penanaman yang rapat serta jumlah benih yang banyak tidak selalu berkontribusi positif, karena tingkat persaingan terhadap serapan hara dan matahari justru menjadi penghambat dalam pertumbuhan tanaman, dampak akhirnya pada capaian produksi yang rendah.

\section{c. Pupuk Urea}

Penggunaan pupuk Urea pada usahatani kapas berpengaruh positif dan signifikan pada taraf kepercayaan $99 \%$ terhadap produksi kapas. Nilai elastisitas Urea terhadap produksi sebesar 0,229 menunjukkan bahwa penambahan Urea sebesar $1 \%$ akan meningkatkan produksi kapas sebesar 0,229\%, cateris paribus. Penambahan penggunaan Urea dapat berdampak signifikan terhadap produksi karena Urea memegang peranan utama dalam menentukan produksi, menurut Kadarwati (2006) unsur nitrogen yang merupakan kandungan utama pada Urea merupakan hara yang paling banyak dibutuhkan oleh tanaman kapas, mulai dari fase pembungaan sampai pembuahan tanaman.

Peranan unsur nitrogen pada tanaman selain mampu menunjang pertumbuhan vegetatif juga mempertahankan boll dari keguguran, sehingga mampu meningkatkan jumlah boll saat panen. Dengan demikian, penambahan penggunaan Urea, walaupun dalam jumlah yang sedikit akan berpengaruh nyata terhadap peningkatan produksi kapas. Penambahan jumlah Urea dari yang digunakan sekarang masih mungkin dilakukan, penggunaan pupuk Urea di lokasi studi berdasrakan data yang diperoleh sebesar $116 \mathrm{~kg} / \mathrm{ha}$. Sementara untuk Urea sendiri rekomendasi teknis penggunaannya untuk tanaman kapas sebesar 100 $\mathrm{kg} / \mathrm{ha}$. Namun karena sifat rekomendasi pemupukan sangat spesifik lokasi, maka kebutuhan Urea sangat bervariasi bergantung pada tingkat kesuburan tanahnya. Menurut Hasnam et al, (1985) kadar hara $\mathrm{N}$ dalam tanah pada daerah pengembangan kapas umumnya sangat rendah $(\mathrm{N}$ total $<1,00 \%)$ sampai rendah ( $\mathrm{N}$ total 1,00 - 2,00\%), oleh karena itu harus ditambahkan melalui pemupukan, 
khususnya melalui pemberian pupuk Urea. Ditambahkan oleh Hasnam et al, (1985) diperlukan kombinasi pemupukan dengan unsur belerang (S) dan $\mathrm{N}$ untuk memberikan hasil terbaik di daerah pengembangan Jeneponto dan Bulukumba, Sulawesi Selatan.

\section{d. Pupuk NPK}

Hasil pada Tabel 5.1 menunjukkan bahwa variabel pupuk NPK berpengaruh positif dan tidak nyata terhadap peningkatan produksi kapas. Nilai koefisiesn variabel pupuk NPK pada model sebesar 0,023. Angka tersebut menunjukkan bahwa peningkatan pupuk NPK sebesar $1 \%$ akan meningkatkan produksi kapas sebesar 0,023\%. Dampak perubahan yang kecil menunjukkan bahwa penggunaan pupuk NPK sudah mendekati jumlah maksimum dan atau diperkirakan penggunaan pupuk Urea sudah cukup mendominasi, sehingga penggunaan pupuk NPK dan Urea secara bersama-sama akan meningkatkan akumulasi unsur $\mathrm{N}$, akibatnya penambahan pemupukan melalui penggunaan pupuk majemuk NPK tidak lagi berpengaruh terhadap produksi kapas petani. Hal lain yang juga perlu diperhatikan menurut Sumaryanto (2001) bahwa alokasi optimal pupuk makro $(\mathrm{N}, \mathrm{P}, \mathrm{K})$ dipengaruhi oleh banyak faktor seperti $\mathrm{pH}$ tanah, kandungan unsur-unsur lain yang mempengaruhi ketersediaan pupuk makro tersebut, kapasitas tukar kation (KTK) tanah, cara pemupukan dan karakteristik pupuk yang diaplikasikan (kandungan dan struktur fisik).

\section{e. Pupuk ZA}

Pupuk ZA diketahui berpengaruh negatif dan tidak signifikan terhadap peningkatan produksi kapas. Nilai koefisien sebesar negatif 0,040 sebagaimana ditunjukkan pada Tabel 5.1 berarti bahwa peningkatan penggunaan pupuk ZA sebesar $1 \%$ akan menurunkan produksi kapas sebesar 0,040\%, cateris paribus. Rata-rata jumlah ZA yang digunakan petani sebesar 74,92 kg/ha. Hal ini berarti jumlah pupuk ZA yang diberikan telah melampaui penggunaan ZA berdasarkan pemupukan anjuran $(50 \mathrm{~kg})$ atau telah mencapai batas maksimum. Hal ini juga dapat dijelaskan bahwa unsur S yang dibutuhkan tanaman telah terkandung dalam 
pupuk majemuk Phonska (NPK), sehingga dampak penggunaan pupuk ZA dan Phonska secara bersama-sama akan meningkatkan akumulasi unsur S, hingga berlaku the law of diminishing return.

\section{f. Pupuk SP 36}

Penggunaan pupuk SP-36 pada usahatani kapas berpengaruh positif dan signifikan pada taraf kepercayaan $95 \%$ terhadap produksi kapas. Nilai elastisitas SP-36 terhadap produksi sebesar 0,111. Hal ini berarti bahwa penambahan penggunaan SP-36 sebesar 1\% akan meningkatkan produksi kapas sebesar $0,111 \%$, cateris paribus.

Phosfor pada tanaman berfungsi sebagai penyusun karbohidrat dan asam amino, merupakan faktor internal yang mempengaruhi induksi pembungaan, sehingga akan mendorong pembentukan buah. Sementara itu peningkatan produksi yang tidak responsif sebagai akibat penambahan SP-36 erat kaitannya dengan ketersediaan phospat (kandungan unsur SP-36) yang terdapat dalam tanah. Jumlah SP-36 yang digunakan petani dalam penelitian ini berkisar antara 50 - 200 $\mathrm{kg} / \mathrm{ha}$, dengan rata-rata $76 \mathrm{~kg} / \mathrm{ha}$. Jumlah pemberian pupuk SP-36 ini masih lebih rendah dari rekomendasi pemupukan (100 kg/ha). Kondisi seperti ini umum terjadi di Sulsel, karena lahan penanaman kapas juga umumnya lahan yang sebelumnya ditanami padi. Menurut Kadarwati et al, (2006) pemupukan P pada kapas di lahan sawah masih menyimpan residu pemupukan sebelumnya, sehingga masih dapat dimanfaatkan tanaman kapas yang ditanam sesudahnya.

\section{d. Insektisida}

Variabel insektisida pada fungsi produksi diketahui berkorelasi positif dan signifikan. Angka koefisien sebesar 0,172 menunjukkan bahwa penambahan penggunaan insektisida sebesar $1 \%$ akan meningkatkan produksi kapas sebesar $0,172 \%$. Insektisida yang digunakan merupakan jenis insektisida padat, yakni Batador, Marshall dan Comfidor. Besarnya dosis anjuran insektisida tergantung dari merek yang digunakan karena setiap merek dagang memiliki dosis dan cara penggunaan yang berbeda-beda. Rata-rata jumlah insektisida yang digunakan 
petani responden sebanyak 212 gr/ha. Penggunaan insektisida di lokasi studi masih merupakan satu-satunya cara yang paling ampuh bagi petani, karena dampak aplikasinya langsung dapat terlihat, khususnya dalam mengendalikan serangan ulat yang menyerang boll tanaman.

Tanaman kapas diserang oleh berbagai serangga hama dan beberapa diantaranya berperan sebagai hama utama, yaitu Amrasca biguttula (pengisap daun), Helicoverpa armigera dan Pectinophora gossypiella (penggerek buah). Ketiga hama ini menyerang tanaman kapas secara berurutan sejak awal hingga akhir pertumbuhan tanaman (Indrayani et al, 2010). Oleh karena itu penggunaan insektisida secara nyata akan mempengaruhi tingkat produksi tanaman. Namun demikian karena pada saat yang bersamaan, penggunaan insektisida dapat berpengaruh terhadap kualitas lingkungan, maka prinsip kehatihatian mesti senantiasa diterapkan dalam menentukan jumlah dosis yang diaplikasikan pada pertanaman kapas, termasuk mempertimbangkan penggunaan kapas lokal yang memiliki ketahanan terhadap serangan hama utama.

\section{e. Herbisida}

Variabel herbisida berkorelasi positif dengan koefisien sebesar 0,102 yang menunjukkan bahwa setiap penambahan penggunaan herbisida sebesar $1 \%$ akan meningkatkan produksi sebesar $0,102 \%$. Penggunaan herbisida di lapangan pada pertanaman kapas berperan dalam menekan dan memberantas pertumbuhan gulma. Hal ini karena dampak penggunaan herbisida akan berpengaruh terhadap tingkat persaingan tanaman dengan gulma, yang biasanya bersaing dalam hal pemanfaatan hara, air dan cahaya sepanjang fase pertumbuhan tanaman.

Aplikasi herbisida yang dilakukan sebelum tanam akan menghambat pertumbuhan gulma, sehingga pertumbuhan awal tanaman kapas akan optimal karena terhindar dari terjadinya persaingan dengan gulma. Pada saat fase generatif, aplikasi herbisida yang bertujuan menekan pertumbuhan gulma akan memacu pembentukan boll sehingga mampu meningkatkan produksi serat kapas di saat panen. Penggunaan herbisida juga mempunyai sisi positif dalam kaitannya 
dengan curahan tenaga kerja, karena penggunaan herbisida dalam pemeliharaan tanaman akan menghemat penggunaan tenaga kerja.

\section{f. Tenaga Kerja}

Tenaga kerja pada fungsi produksi stochastic frontier bernilai positif. Secara statistik, penambahan tenaga kerja juga berdampak signifikan terhadap produksi. Penambahan tenaga kerja sebesar 1\%, cateris paribus akan meningkatkan produksi kapas sebesar 0,643\%. Penambahan tenaga kerja terutama diperlukan dalam kegiatan pemeliharaan dan panen. Rata-rata tenaga kerja yang digunakan dalam usahatani kapas mulai dari pengolahan lahan hingga pasca panen yaitu sebanyak $48 \mathrm{HOK} / \mathrm{ha}$. Perhitungan tenaga kerja pada model fungsi produksi per satuan lahan merupakan tenaga kerja total, baik dari tenaga kerja dalam keluarga maupun tenaga kerja luar keluarga, mulai dari pengolahan lahan hingga panen.

Alokasi tenaga kerja pada pertanaman kapas, khususnya pada saat pemeliharaan sangat menentukan tingkat pertumbuhan tanaman secara umum. Hal ini sangat berkaitan dengan penggunaan input khususnya benih dan pemberian unsur hara melalui pemupukan. Jumlah tenaga kerja yang optimum menunjukkan kinerja pengelolaan input yang optimal, sehingga dampak akumulasi tenaga kerja di lapangan adalah besaran produksi yang dihasilkan. Menurut Tohir (Soekartawi, 2002) tenaga kerja pertanian memiliki corak yang khas, diantaranya pemakaian tenaga kerja dalam usahatani untuk tiap hektar terbatas, sehingga untuk meningkatkan daya tampung per hektarnya dapat ditempuh dengan intensifikasi kerja dan manajemen input yang baik. Selain itu kebutuhan tenaga kerja dalam suatu usahatani tidak kontinyu dan merata.

Ringkasan statistik penggunaan faktor produksi pada usahatani kapas per hektar dapat dilihat pada tabel 5.2, yang menjelaskan tingkat produksi yang diperoleh berdasarkan interaksi dari penggunaan berbagai input produksi. 
Tabel 5.2. Deskripsi Statistik Input Produksi Kapas per Hektar di Sulsel

\begin{tabular}{lcccr}
\hline Variabel Input/output & Rata-rata & Std.Dev & Minimum & Maksimum \\
\hline \multicolumn{1}{c}{ Output } & \multicolumn{5}{c}{205} & 292 & 1.629 \\
\hline \multicolumn{1}{c}{ Serat kapas berbiji (kg/ha) } & 636 & 1 & 5 & 8 \\
\hline Benih (kg/ha) & 6 & 67,28 & 50 & 400 \\
Urea (kg/ha) & 116,39 & 38,94 & 50 & 200 \\
NPK (kg/ha) & 83,03 & 31,79 & 50 & 200 \\
ZA (kg/ha) & 74,92 & 33,31 & 50 & 200 \\
SP-36 (kg/ha) & 76,26 & 112,55 & 100 & 600 \\
Insektisida (gr/ha) & 212,67 & 2,28 & 1,33 & 8 \\
Herbisida (ltr/ha) & 3,98 & 16,04 & 28 & 100 \\
Tenaga Kerja (HOK/ha) & 48,06 & & &
\end{tabular}

Tingkat produktivitas usahatani kapas pada kegiatan MT. 2011 untuk rataan petani contoh adalah sebesar $636 \mathrm{~kg}$ serat kapas berbiji per hektarnya, dengan kisaran antara $205-1.629 \mathrm{~kg} / \mathrm{ha}$. Produktivitas yang diperoleh tersebut, memberi gambaran bahwa varietas kapas yang digunakan belum memberikan tingkat produksi optimal, berdasarkan potensi hasil dari kapas hibrida HSC 138 yakni sekitar $580-2.609 \mathrm{~kg} / \mathrm{ha}$ (Suhendar, 2007). Hasil ini juga masih belum bisa mencapai tingkat produksi kapas per hektar yang diperoleh pada pengembangan kapas transgenik yang pernah dilakukan sebelumnya dengan rata-rata produktivitas masing-masing $2.100 \mathrm{~kg} / \mathrm{ha}, 2.350 \mathrm{~kg} / \mathrm{ha}$ dan $2.183 \mathrm{~kg} / \mathrm{ha}$ (Syam, 2005; Thamrin, 2007; Ibrahim, 2008).

Sementara itu dalam tingkat usahatani jumlah input yang digunakan dan output yang diperoleh dapat dilihat pada Tabel 5.3. 
Tabel 5.3. Deskripsi Statistik Input Kapas per Usahatani di Sulsel

\begin{tabular}{|c|c|c|c|c|}
\hline Variabel Input/output & Rata-rata & Std.Dev & Minimum & Maksimum \\
\hline \multicolumn{5}{|l|}{ Output } \\
\hline Serat kapas berbiji (kg) & 489 & 322 & 104 & 2.959 \\
\hline \multicolumn{5}{|l|}{ Input } \\
\hline Lahan (ha) & 0,76 & 0,32 & 0,25 & 2 \\
\hline Benih (kg) & 4,60 & 1,82 & 1,50 & 12 \\
\hline Urea $(\mathrm{kg})$ & 83,58 & 51,75 & 12,50 & 300 \\
\hline NPK $(\mathrm{kg})$ & 58,58 & 29,50 & 12,50 & 200 \\
\hline $\mathrm{ZA} \mathrm{(kg)}$ & 52,58 & 13,68 & 12,50 & 150 \\
\hline SP-36 (kg) & 53,42 & 24,19 & 12,50 & 150 \\
\hline Insektisida (gr) & 141,33 & 165,73 & 100 & 300 \\
\hline Herbisida (ltr/) & 2,70 & 1,30 & 1 & 8 \\
\hline Tenaga Kerja (HOK/) & 32,65 & 7,68 & 20 & 62 \\
\hline
\end{tabular}

Hasil penelitian Kanro dan Kadir (2006) terkait interaksi beberapa kultivar kapas di lima daerah pengembangan di Sulsel menunjukkan bahwa produktivitas varietas HSC 138 berada dibawah HSC 188, yakni $1.053 \mathrm{~kg} / \mathrm{ha}$ berbanding $1.728 \mathrm{~kg} / \mathrm{ha}$. Kedua varietas ini juga tidak termasuk kultivar yang mempunyai stabilitas tinggi, walaupun HSC 188 masih tergolong kultivar yang beradaptasi baik pada lingkungan yang menguntungkan.

Terkait dengan pemupukan pada tanaman kapas, jumlah hara yang diberikan pada tanaman dalam bentuk pupuk an organik menunjukkan bahwa rata-rata pemberian pupuk belum konsisten dengan rekomendasi pemupukan anjuran dari dinas terkait. Pemberian Urea dan ZA secara rata-rata sedikit berada di atas rekomendasi pemupukan yang dianjurkan, sementara untuk SP-36 justru digunakan lebih sedikit dari dosis anjuran. Petani juga tidak melakukan pemupukan menggunakan pupuk $\mathrm{KCl}$, yang disebabkan karena pengadaan pupuk jenis ini memerlukan pengeluaran tambahan yang lebih besar karena harganya yang mahal. Petani umumnya meningkatkan pemberian Urea dan ZA karena kedua pupuk ini selain menunjukkan dampak langsung pada fase pertumbuhan vegetatif tanaman, juga karena harganya masih relatif terjangkau oleh petani. 


\subsection{Tingkat Efisiensi Teknis dan Inefisiensi Teknis}

Soekartawi (1987) menjelaskan bahwa tersedianya sarana atau faktor produksi (input) belum berarti produktifitas yang diperoleh petani akan tinggi. Namun bagaimana petani melakukan usahanya secara efisien adalah upaya yang sangat penting. Berikut adalah pembahasan mengenai tingkat efisiensi dan inefisiensi teknis meliputi sebaran efisiensi teknis dan sumber-sumber inefisiensi teknis yang diperoleh dari usahatani kapas.

\subsubsection{Sebaran Efisiensi Teknis}

Efisiensi teknis dianalisis secara simultan dengan menggunakan model fungsi produksi stochastic frontier. Sebaran efisiensi teknis usahatani kapas di lokasi penelitian ditampilkan pada Tabel 5.4. Nilai indeks efisiensi hasil analisis dapat dikategorikan efisien dalam menggunakan input produksi apabila nilainya mendekati 1 . Kategori yang digunakan dalam penelitian adalah sangat efisien bila memiliki nilai $0,90 \mathrm{ke}$ atas, cukup efisien apabila nilainya berada antara 0,7 hingga 0,89 dan belum efisien apabila nilainya lebih kecil dari 0,70

Hasil analisis stochastic frontier di lokasi studi menunjukkan nilai rata-rata efisiensi teknis relatif usahatani kapas untuk masing-masing kabupaten. Dilihat dari distribusi nilai efisiensi menurut kabupaten, usahatani kapas secara umum memiliki tingkat rata-rata efisiensi yang sama, tapi efisiensi terendah terdapat di Kabupaten Soppeng dan petani yang paling efisien terdapat di Kabupaten Bulukumba.

Tabel 5.4. Sebaran Efisiensi Teknis Usahatani Kapas Petani Responden di Sulawesi Selatan Menurut Kabupaten

\begin{tabular}{lcccc}
\hline \multirow{2}{*}{ Kabupaten } & \multirow{2}{*}{ Jumlah Petani } & \multicolumn{3}{c}{ Efisiensi Teknis } \\
\cline { 3 - 5 } & & Mean & Maksimum & Minimum \\
\hline Soppeng & 30 & 0,66 & 0,99 & 0,36 \\
Bone & 50 & 0,64 & 0,99 & 0,41 \\
Bulukumba & 70 & 0,66 & 0,99 & 0,45 \\
\hline Sulsel & 150 & 0,65 & 0,99 & 0,36 \\
\hline
\end{tabular}

Sumber : Analisis Data Primer, 2012 
Secara keseluruhan, mayoritas petani belum efisien secara teknis. Dari 150 petani responden, sebanyak 98 petani $(34,67 \%)$ masih memiliki nilai efisiensi di bawah 0,70. Rata-rata nilai efisiensi teknis petani kapas di lokasi penelitian yaitu sebesar 0,65 dengan nilai terendah 0,36 dan nilai tertinggi 0,99. Artinya, rata-rata petani belum dapat mencapai potensial produksi berdasarkan kombinasi penggunaan input produksi yang dikorbankan dan masih terdapat 35\% (1 $0,65 / 0,99)$ peluang untuk meningkatkan produksi kapas. Sebaran efisiensi teknis usahatani kapas di lokasi penelitian ditampilkan pada Tabel 5.5.

Besaran efisiensi teknis yang diperoleh pada studi ini berbeda dengan yang diperoleh pada penelitian Syam (2004) sebelumnya, yakni 0,71. Perubahan ini salah satunya karena tingkat penggunaan input. Besaran input yang direkomendasikan dan digunakan saat pengembangan kapas transgenik pada penelitian tersebut lebih besar dibanding bantuan input yang sekarang disediakan pemerintah saat ini*. Hal ini bisa dikonfirmasi dari penelitian Battese dan Hassan (1999), yang menemukan perbedaan efisiensi karena perbedaan aktivitas budidaya, khususnya dalam pemanfaatan input. Nilai efisiensi yang diperoleh dalam studi ini justru tidak berbeda dengan penelitian untuk komoditi yang sama sebagaimana dilakukan Hussain (1999) di Punjab Pakistan yakni 0,65 dan sedikit lebih besar dibandingkan hasil efisiensi teknis yang diperoleh Bravo-Ureta dan Evenson (1994) di Paraguay dengan nilai efisiensi teknis 0,58.

Dilihat dari sebaran nilai efisiensi teknisnya (Tabel 5.5), mayoritas petani responden $(52,00 \%)$ memiliki nilai efisiensi pada kisaran 0,50 hingga 0,69. Sementara itu, petani yang efisiensinya berada pada kisaran 0,70 hingga 0,99 sebanyak 52 orang petani (34,67\%). Menurut Sumaryanto (2001), besaran dan sebaran efisiensi teknis mempunyai implikasi yang penting dalam meningkatkan kapabilitas manajerial usahatani melalui penyusunan strategi penyuluhan. Petani kapas di lokasi penelitian yang memiliki nilai efisiensi teknis lebih kecil dari 0,70 perlu melakukan upaya peningkatan manajerial usahatani. Upaya ini dapat

\footnotetext{
*) Penggunaan pupuk untuk kapas transgenik terdiri dari; Urea 150 kg/ha, ZA 50 kg/ha, 100 SP-36 $100 \mathrm{~kg} / \mathrm{ha}$ dan KCl 50 kg/ha (Syam, 2004)
} 
dilakukan dengan menerapkan keterampilan dan teknik budidaya sebagaimana yang dilakukan oleh petani yang paling efisien.

Tabel 5.5. Sebaran Efisiensi Teknis Usahatani Kapas Petani Responden di Sulawesi Selatan

\begin{tabular}{|c|c|c|c|c|c|}
\hline \multirow{2}{*}{$\begin{array}{c}\text { Kelompok } \\
\text { Efisiensi Teknis }\end{array}$} & \multicolumn{3}{|c|}{ Jumlah Petani } & \multirow{2}{*}{ Total } & \multirow{2}{*}{$\begin{array}{c}\text { Persentase } \\
(\%)\end{array}$} \\
\hline & Soppeng & Bone & Bulukumba & & \\
\hline $0.30-0,39$ & 1 & 0 & 0 & 1 & 0,67 \\
\hline $0,40-0,49$ & 3 & 8 & 2 & 13 & 8,67 \\
\hline $0,50-0,59$ & 7 & 14 & 21 & 42 & 28,00 \\
\hline $0,60-0,69$ & 6 & 13 & 23 & 42 & 28,00 \\
\hline $0,70-0,79$ & 4 & 7 & 16 & 27 & 18,00 \\
\hline $0,80-0,89$ & 7 & 6 & 7 & 20 & 13,33 \\
\hline $0,90-0,99$ & 2 & 2 & 1 & 5 & 3,33 \\
\hline Total & 30 & 50 & 70 & 150 & 100,00 \\
\hline Rata-rata TE & 0,65 & & & & \\
\hline Minimum TE & 0,36 & & & & \\
\hline Maksimum TE & 0,99 & & & & \\
\hline
\end{tabular}

Berdasarkan Tabel 5.5, sebaran efisiensi dengan jumlah petani yang berada pada tingkat yang efisien terbanyak di Kabupaten Soppeng, diikuti Bulukumba dan Bone, yakni masing-masing 43,33\% (13/30), 34,29\% (24/70) dan $30 \%(15 / 50)$. Adanya perbedaan sebaran tingkat efisiensi pada masing-masing kabupaten diantaranya disebabkan oleh perbedaan penggunaan input produksi, penggunaan input produksi yang berpengaruh terhadap produksi kapas di Kabupaten Soppeng lebih tinggi dibanding Kabupaten Bulukumba dan Bone. Hal ini mengacu pada pemahaman tentang produksi yang efisien menurut Lipsey (1995) yang diperoleh pada beberapa situasi berikut. Pertama, apabila dengan input yang sama menghasilkan output yang lebih besar. Kedua, apabila dengan input yang lebih kecil menghasilkan output yang sama, dan yang terakhir dengan input yang lebih besar menghasilkan output yang lebih besar. Kinerja terbaik usahatani kapas diperoleh dari tingkat pemanfaatan input yang optimal, kondisi ini berdasarkan tingkat output yang dicapai dari kombinasi penggunaan input tertentu. Rata-rata penggunaan input usahatani kapas dapat dilihat pada Tabel 5.6 
Tabel 5.6. Rata-rata Tingkat Penggunaan Input Usahatani Kapas di Sulawesi Selatan Menurut Kabupaten.

\begin{tabular}{cccccc}
\hline \multirow{2}{*}{ Kabupaten } & \multicolumn{5}{c}{ Jumlah Input $(\mathrm{kg})$} \\
\cline { 2 - 6 } & Urea & SP-36 & Insektisida & Herbisida & Tenaga Kerja \\
\hline Soppeng & 110,53 & 85,13 & 210,03 & 3,84 & 47,26 \\
Bone & 84,70 & 63,39 & 150,82 & 3,21 & 39,96 \\
Bulukumba & 136,20 & 70,45 & 208,08 & 3,80 & 43,86 \\
\hline Sumber: Analisis & Data Primer 2012 & & &
\end{tabular}

Sumber : Analisis Data Primer, 2012

\subsubsection{Sumber Inefisiensi Teknis}

Faktor-faktor yang mempengaruhi tingkat efisiensi teknis petani responden dianalisis dengan menggunakan model efek inefisiensi teknis dari fungsi produksi stochastic frontier sebagaimana disajikan pada Tabel 5.7.

Tabel 5.7. Fungsi Produksi Stochastic Frontier Model Inefisiensi Teknis Usahatani Kapas dengan Metode MLE

\begin{tabular}{lcccr}
\hline Variabel & Parameter & Tanda Harapan & Koefisien & T-Rasio \\
\hline Intersep & $\delta 0$ & $(+/-)$ & $0,732^{* * * *}$ & 4,453 \\
$\ln U m$ & $\delta 1$ & + & $-0,005^{* *}$ & $-2,177$ \\
$\ln P g 1$ & $\delta 2$ & - & 0,013 & 0,824 \\
$\operatorname{lnPd}$ & $\delta 3$ & - & $-0,008$ & $-1,144$ \\
$\operatorname{lnRt}$ & $\delta 4$ & - & $-0,008$ & $-0,516$ \\
$\operatorname{lnKt}$ & $\delta 5$ & - & $-0,009$ & $-0,510$ \\
\hline
\end{tabular}

Sumber : Analisis Data Primer, 2012

Keterangan :

****) $=$ Signifikan pada taraf $\alpha=1 \%$

$\left.{ }^{* *}\right)=$ Signifikan pada taraf $\alpha=5 \%$

Berdasarkan hasil pendugaan model efek inefisiensi teknis pada Tabel 5.7, diketahui bahwa variabel umur petani (Um) berkorelasi negatif dan signifikan terhadap inefisiensi teknis usahatani kapas, artinya umur petani berpengaruh positif terhadap efisiensi petani, yang dapat dimaknai bahwa tingkat efisiensi usahatani meningkat seiring terjadinya pertambahan usia petani, terutama pada usia produktif. Hasil ini sejalan dengan beberapa penelitian sebelumnya yang membahas tentang pengaruh umur terhadap inefisiensi teknis (Hussain, 1999 dan Tzouvelekas et al, 2001).

Sementara itu, variabel pendidikan formal (Pd), jumlah anggota keluarga (Rt) dan lama bergabung dalam kelompok tani (Kt) menunjukkan hasil yang 
sesuai dengan harapan, yakni negatif namun tidak signifikan. Hal ini berarti variabel yang disebutkan berkorelasi positif terhadap efisiensi walaupun tidak berpengaruh secara nyata. Sebaliknya terjadi pada variabel pengalaman usahatani (Pgl) memiliki ketidaksesuaian dengan nilai harapan, tanda yang diperoleh menunjukkan korelasi positif terhadap inefisiensi, yang berarti bertambahnya pengalaman petani tidak linear dengan efisiensi petani dan justru tingkat efisiensinya menurun. Namun demikian variabel pengalaman usahatani ini juga tidak signifikan, yang berarti tidak berpengaruh nyata terhadap efisiensi teknis usahatani kapas.

\section{a. Umur}

Variabel umur diikutsertakan ke dalam model dengan dugaan awal berpengaruh positif terhadap inefisiensi teknis (negatif terhadap efisiensi teknis). Namun demikian Tabel 5.7 menunjukkan hasil sebaliknya, variabel umur berpengaruh nyata dan negatif terhadap inefisiensi pada taraf kepercayaan 95\%, hal ini berarti bahwa semakin tua petani semakin efisien secara teknis. Kondisi ini menjelaskan bahwa selain kemampuan fisik, sikap mental bisa jadi berperan penting dalam mendorong pencapaian kemajuan pengelolaan usahatani kapas guna meningkatkan produktivitas.

Menurut Widodo (1989) petani yang berusia tua bisa jadi lebih baik dari petani yang muda, karena memiliki pengalaman yang lebih banyak dan keterampilan yang lebih baik. Berdasarkan sebaran umurnya, mayoritas petani responden $(36,67 \%)$ berumur antara $41-50$ tahun, 36,00\% secara akumulatif berada pada usia 20-40 tahun dan sisanya berumur diatas 50 tahun (27,33\%). Petani yang berumur lebih matang, biasanya akan melakukan perubahan dan perbaikan dalam kondisi dan situasi yang mendukung. Bantuan teknis dan bantuan input produksi pada program akselerasi pengembangan kapas rakyat, diduga memberi dampak perubahan perilaku petani yang mampu membangun sikap mental yang dinamis dalam usaha tani kapas. 


\section{b. Pengalaman Usahatani}

Pengalaman usahatani pada model inefisiensi teknis pada awalnya diduga berpengaruh positif terhadap pencapaian efisiensi teknis (inefisiensi negatif). Asumsinya bahwa pengalaman usahatani yang dimiliki petani berkaitan dengan teknologi budidaya kapas akan menjadikan petani lebih terampil dan memiliki kemampuan manajerial yang baik, hal ini terkait dengan akumulasi pengetahuan dan pengalaman pengelolaan beberapa waktu sebelumnya. Namun nilai koefisien yang positif memiliki ketidaksesuaian dengan nilai harapan. Disisi lain nilai yang diperoleh juga tidak signifikan, artinya dalam kasus ini, pengalaman seorang petani dalam usahatani kapas, tidak berpengaruh terhadap ketidakefisienan usahatani kapas. Jika dihubungkan dengan kegiatan pendampingan yang diperoleh pada berbagai tingkatan petani, bisa jadi pengalaman berusahatani kapas menjadi tidak relevan terhadap tingkat manajerial petani, apalagi secara teknis budidaya kapas memiliki kesamaan dengan teknis budidaya jagung dan kacang-kacangan yang selama ini sudah diusahakan petani, bahkan telah ditumpangsari dengan tanaman kapas.

\section{c. Pendidikan Formal}

Pendidikan formal merupakan lamanya waktu (tahun) yang dihabiskan petani untuk menjalankan pendidikan formalnya. Variabel pendidikan formal dianggap sebagai proxy dari kemampuan manajerial petani. Semakin tinggi pendidikan formal yang dimiliki petani, maka petani memiliki kemampuan yang lebih baik untuk menerapkan teknologi baru dan mengalokasikan sumberdaya yang ada secara optimal. Hasil yang diperoleh dari Tabel 5.7 menunjukkan hasil yang sesuai dengan harapan dan dugaan awal, karena pendidikan formal berkorelasi negatif, namun tidak signifikan terhadap inefisiensi (positif terhadap efisiensi). Hal ini berarti lamanya pendidikan formal yang ditempuh tidak berpengaruh terhadap tingkat efisiensi usahatani kapas di lokasi penelitian. 
Berdasarkan sebaran tingkat pendidikan formal petani (Tabel 4.5), terdapat $54,67 \%$ petani berpendidikan formal setingkat SD (lama pendidikan 6 tahun). Jika dikaitkan dengan tingkat pendidikan yang masih rendah ini, masih diperlukan adanya upaya peningkatan pengetahuan melalui penyuluhan, pelatihan, dan demonstrasi sebagai suatu cara meningkatkan pengetahuan dan kemampuan penguasaan teknologi baru.

\section{d. Jumlah Anggota Keluarga}

Variabel jumlah anggota keluarga menunjukkan hubungan yang negatif dan tidak signifikan terhadap tingkat inefiesensi teknis. Hal ini walaupun sesuai dengan dugaan awal bahwa semakin banyak anggota keluarga, maka efisiensi teknis akan semakin besar, namun tidak signifikan terhadap peningkatan produksi melalui perbaikan manajerial. Dari hasil analisis stochastic frontier diketahui bahwa variabel jumlah anggota keluarga ternyata tidak berpengaruh signifikan dan tidak dapat dianggap sebagai faktor yang mempengaruhi efisiensi teknis usahatani. Anggota keluarga yang dimiliki petani kapas di lokasi penelitian bisa jadi belum cukup terampil untuk membantu usahatani kapas secara langsung, disebabkan umur yang masih tergolong muda, sehingga pemanfaatan tenaga kerja luar keluarga lebih efisien secara teknis dibanding tenaga kerja dalam keluarga.

\section{e. Lama Bergabung dalam Kelompok Tani}

Variabel lama bergabung dalam kelompok tani yang dimasukkan dalam model inefisiensi teknis diduga akan berhubungan positif terhadap efisiensi teknis (negatif terhadap inefisiensi). Hasil inefisiensi yang didapat pada Tabel 5.7 sesuai dengan dugaan awal, yakni negatif, namun tidak signifikan. Hal ini menunjukkan bahwa efisiensi teknis yang diperoleh petani pada aktivitas usahataninya tidak berhubungan dengan lamanya seorang petani bergabung dalam suatu kelompok tani. Lamanya petani bergabung dalam kelompok tani kapas tidak menjamin usahatani kapasnya akan menjadi lebih efisien. 
Secara umum keberadaan kelompok tani dalam pelaksanaan program akselerasi pengembangan kapas sangat penting dalam menghimpun kekuatan kerjasama antar sesama anggota, mempermudah koordinasi dan konsultasi dengan pemerintah sebagai pendamping dan perusahaan mitra serta menjadi syarat utama untuk mendapatkan bantuan modal dalam usahatani kapas. Walaupun demikian di dalam kelompok tani, faktor keterlibatan anggota menjadi sangat penting, keterlibatan petani dalam kegiatan kelompok khususnya kegiatan penyuluhan akan sangat diperlukan sebagai upaya mendorong pencapaian efisiensi teknis. Faktor pendorong petani terlibat dalam kelompok tani bisa jadi tidak sepenuhnya karena mengharapkan adanya pembinaan dan pendampingan secara luas, tapi lebih didorong karena keterikatan persyaratan untuk terlibat dalam program akselerasi pengembangan kapas ini untuk mendapatkan bantuan sosial input produksi. Faktor ini bisa sangat menghambat, sehingga dapat mengurangi tingkat efisiensi petani dalam usahatani kapas.

\subsection{Efisiensi Ekonomi dan Alokatif}

Efisiensi alokatif merupakan kemampuan petani kapas untuk memilih tingkat penggunaan input minimum pada kondisi harga-harga faktor produksi dan teknologi tetap. Secara alokatif dikatakan efisien jika pada tingkat hargaharga masukan dan keluaran tertentu, proporsi penggunaan masukan sudah optimum. Ini terjadi karena penerimaan produk marginal (marginal revenue product) sama dengan biaya marginal (marginal cost) masukan yang digunakan.

Hasil estimasi Efisien Alokatif (AE) yang didasarkan pada estimasi fungsi biaya pada usahatani kapas di lokasi penelitian pada teknologi yang tersedia dan harga- harga faktor produksi menggunakan MLE ditunjukkan pada Tabel 5.8. Koefisien gamma $(\gamma)$ sebesar 0,675 dan secara statistik signifikan pada taraf $1 \%$ menunjukkan bahwa terdapat $0,375 \%$ dari total variasi output kapas yang disebabkan oleh inefisiensi. 
Adapun faktor yang berpengaruh terhadap capaian efisiensi alokatif ditunjukkan pada hasil perhitungan estimasi fungsi biaya produksi stochactic frontier disajikan pada Tabel 5.8.

Tabel 5.8. Fungsi Biaya Produksi Stochastic Frontier Usahatani Kapas dengan Metode MLE

\begin{tabular}{lcccr}
\hline \multicolumn{1}{c}{ Variabel } & Parameter & Tanda Harapan & Koefisien & \multicolumn{1}{c}{ T-Rasio } \\
\hline Intersep & $\alpha 0$ & $(+/-)$ & $-24,236^{* * * *}$ & $-24,274$ \\
LnHUr & $\alpha 1$ & + & $1,726^{* *}$ & 1,882 \\
LnHNpk & $\alpha 2$ & + & 0,604 & 0,891 \\
LnHSp & $\alpha 3$ & + & 0,196 & 0,224 \\
LnHIns & $\alpha 4$ & + & 0,310 & 0,374 \\
LnHHer & $\alpha 5$ & + & 0,551 & 0,706 \\
LnHTk & $\alpha 6$ & + & $0,122^{*}$ & 1,417 \\
LnProd & $\alpha 7$ & + & 0,098 & 0,565 \\
Sigma-squared & & & 0,004 & 1,235 \\
Gamma & & & 0,712 & 0,753 \\
\hline
\end{tabular}

Sumber : Analisis Data Primer, 2012.

Keterangan :

****) $=$ Signifikan pada taraf $\alpha=1 \%$

**) = Signifikan pada taraf $\alpha=5 \%$

$\mathrm{t}_{\text {Tabel } \alpha} 1 \%=2,576$

$\mathrm{t}_{\text {Tabel } \alpha} 5 \%=1,645$

*) $=$ Signifikan pada taraf $\alpha=10 \%$

$\mathrm{t}_{\text {Tabel } \alpha} 10 \%=1,282$

Hasil penelitian sebagaimana yang dapat dilihat pada Tabel 5.8 menunjukkan bahwa semua variabel independen sesuai dengan harapan awal karena semua nilai koefisien estimasi (harga Urea, harga NPK, harga SP-36, harga insektisida, harga herbisida dan upah tenaga kerja serta jumlah output) bernilai positif. Hal ini berarti bahwa semua faktor-faktor di atas meningkatkan total biaya produksi, cateris paribus. Hasil Uji t-rasio menunjukkan bahwa terdapat dua variabel yang secara statistik signifikan, masing-masing pada taraf 5\% dan 10\%, yakni harga Urea dan upah tenaga kerja. Sementara kenaikan harga NPK, harga SP-36, harga insektisida dan herbisida tidak akan meningkatkan total biaya produksi secara signifikan.

Pengaruh harga Urea terhadap peningkatan total biaya disebabkan karena kecenderungan aplikasi pupuk Urea yang lebih banyak dan diutamakan penggunaannya oleh petani. Bagi sebagian besar petani, fungsi unsur hara yang dikandung pupuk Urea begitu penting dalam memacu pertumbuhan tanaman 
khususnya pertumbuhan vegetatif, sehingga penggunaan pupuk Urea tidak dapat dipisahkan dalam aktivitas budidaya kapas. Sementara upah tenaga kerja akan signifikan terhadap peningkatan total biaya disebabkan karena seluruh aktivitas budidaya tanaman kapas sangat bergantung pada ketersediaan tenaga kerja, baik tenaga kerja langsung maupun tenaga kerja yang berasal dari dalam keluarga dan diperhitungkan biayanya. Ketergantungan terhadap tenaga kerja tersebut menyebabkan berapa pun nilai upah kerja yang berlaku tetap akan ditanggung oleh petani, karena jika tidak maka proses produksi bisa terhambat atau bahkan terhenti, sehingga output yang diharapkan tidak maksimal.

Frekuensi distribusi efisiensi teknis, alokatif dan ekonomi ditunjukkan pada Tabel 5.9. Penelitian ini menemukan bahwa nilai rata-rata efisiensi teknis, alokatif dan ekonomis masing-masing sebesar 0,65, 0,39 dan 0,62. Penelitian sebelumnya yang menggunakan model analisis yang sama (Hussain, 1999 serta Bravo-Ureta dan Evenson, 1994) juga menunjukkan adanya perbedaan hasil antara ketiga efisiensi yang diperoleh pada tanaman kapas, sebagaimana juga dilakukan oleh Binam et al, (2005) dan Akinbode et al, (2011) pada tanaman padi.

Petani yang memiliki nilai efisiensi teknis lebih besar dari 0,70 sebesar $41,32 \%$. Sedangkan petani yang memiliki nilai efisiensi alokatif yang lebih besar daripada 0,70 lebih sedikit, yakni $35,33 \%$, dan tidak ada petani yang mampu mencapai efisiensi ekonomis di atas 0,70. Ini menunjukkan bahwa sebagian besar petani belum mencapai tingkat efisiensi yang diharapkan. Akibatnya keuntungan petani rendah karena terjadi inefisiensi biaya.

Efisiensi alokatif petani responden berada pada kisaran 0,33 sampai 0,93 dengan rata-rata 0,62 . Hal ini berarti, jika rata-rata petani responden dapat mencapai tingkat efisiensi alokatif yang paling tinggi, maka petani dapat menghemat biaya sebesar 33\% (1 - 0,62/0,93), sedangkan pada petani yang paling tidak efisien dapat menghemat biaya sebesar 65\% $(1-0,33 / 0,93)$. 
Tabel 5.9. Efisiensi Teknis, Efisiensi Ekonomi dan Efisiensi Alokatif Usahatani Kapas di Sulawesi Selatan.

\begin{tabular}{|c|c|c|c|c|c|c|}
\hline \multirow{2}{*}{$\begin{array}{l}\text { Efficiency } \\
\text { Index }\end{array}$} & \multicolumn{2}{|c|}{ Teknis } & \multicolumn{2}{|c|}{ Ekonomi } & \multicolumn{2}{|c|}{ Alokatif } \\
\hline & Frekuensi & Persentase & Frekuensi & Persentase & Frekuensi & Persentase \\
\hline $0.10-0.19$ & 0 & 0 & 0 & 0 & 0 & 0 \\
\hline $0.20-0.29$ & 0 & 0 & 5 & 3,33 & 0 & 0 \\
\hline $0.30-0.39$ & 1 & 0,67 & 68 & 45,33 & 3 & 2,00 \\
\hline $0.40-0.49$ & 13 & 8,67 & 77 & 51,33 & 19 & 12,67 \\
\hline $0.50-0.59$ & 42 & 28,00 & 0 & 0 & 47 & 31,33 \\
\hline $0.60-0.69$ & 42 & 28,00 & 0 & 0 & 40 & 26,67 \\
\hline $0.70-0.79$ & 27 & 18,00 & 0 & 0 & 29 & 19,33 \\
\hline $0.80-0.89$ & 20 & 13,33 & 0 & 0 & 9 & 6,00 \\
\hline 0.90-0.99 & 5 & 3,33 & 0 & 0 & 3 & 2,00 \\
\hline Total & 150 & 100 & 150 & 100 & 150 & 100 \\
\hline Minimum & 0,36 & & 0,28 & & 0,33 & \\
\hline Maksimum & 0,99 & & 0,47 & & 0,93 & \\
\hline Rata-rata & 0,65 & & 0,39 & & 0,62 & \\
\hline
\end{tabular}

Sumber : Analisis Data Primer, 2012

\subsection{Perilaku Petani Terhadap Risiko Produksi Usahatani Kapas}

Pengukuran terhadap perilaku petani di mulai dengan memilih variabel yang paling nyata yang menentukan hasil produksi kapas. Selanjutnya hasil yang diperoleh digunakan untuk menentukan tingkat perilaku petani dalam menghindari risiko. Berdasarkan hasil analisis pada Tabel 5.10, pupuk Urea merupakan variabel input yang paling berpengaruh dan berkontribusi terhadap peningkatan produksi, hal yang sama juga dikemukakan Just dan Pope (1979) yang menemukan bahwa pupuk nitrogen berpengaruh terhadap variabilitas produktivitas, artinya pemberian pupuk ini dapat meningkatkan risiko produksi. Sementara Saptana et al, (2010) dalam penelitiannya juga menemukan bahwa pupuk $\mathrm{N}$ merupakan salah satu input yang bersifat sebagai pengurang risiko. 
Tabel 5.10. Analisis Produksi Usahatani Kapas untuk Menentukan Input yang Berpengaruh

\begin{tabular}{lccrrr}
\hline \multirow{2}{*}{ Variabel } & \multicolumn{2}{c}{$\begin{array}{c}\text { Cnstandardized } \\
\text { Coefficients }\end{array}$} & $\begin{array}{c}\text { Standardized } \\
\text { Coefficients }\end{array}$ & $\mathrm{t}$ & \multirow{2}{*}{ Sig. } \\
\cline { 2 - 5 } & \multicolumn{1}{c}{$\mathrm{B}$} & Std. Error & Beta & & \\
\hline Intersep & 51,065 & 4,280 & & 11,930 & 0,000 \\
Benih & $-0,185$ & 0,242 & $-0,057$ & $-0,762$ & 0,447 \\
Urea & $0,241^{* * *}$ & 0,052 & 0,441 & 4,637 & 0,000 \\
NPK & 0,040 & 0,092 & 0,058 & 0,436 & 0,664 \\
ZA & $-0,105$ & 0,144 & $-0,134$ & $-0,730$ & 0,467 \\
SP-36 & 0,125 & 0,115 & 0,163 & 1,085 & 0,280 \\
Insektisida & $0,115^{*}$ & 0,058 & 0,195 & 1,991 & 0,048 \\
Herbisida & $0,087^{*}$ & 0,044 & 0,148 & 1,992 & 0,048 \\
Tenaga kerja & $-0,114$ & 0,101 & $-0,116$ & $-1,132$ & 0,259 \\
\hline
\end{tabular}

Sumber : Analisis Data Primer, 2012

Keterangan:

$\left.{ }^{* * *}\right)=$ Signifikan pada taraf $\alpha=1 \%$

*) $=$ Signifikan pada taraf $\alpha=10 \%$

Berdasarkan hasil perhitungan (Tabel 5.11) diperoleh gambaran bahwa rata-rata petani responden petani kapas $(64 \%)$ berperilaku netral terhadap risiko (risk neutral), $32 \%$ berperilaku menghindari risiko (risk averter) dan hanya $6 \%$ yang suka risiko (risk lover). Perilaku petani yang netral terhadap risiko mengisyaratkan petani kapas masih berpola pikir safety first yang membuatnya terlalu berhati-hati, akibatnya produktivitas juga belum mencapai optimal. Hasil ini sesuai dengan hipotesis awal yang melihat adanya kecenderungan petani di lokasi penelitian berperilaku netral terhadap risiko produksi. Hal ini terjadi karena usahatani kapas di Sulsel secara umum sangat rentan terhadap terjadinya kegagalan panen, baik karena kekeringan, serangan hama dan rendahnya kualitas benih. Dampak kekurangan air sendiri erat hubungannya dengan aktivitas budidaya atau pemeliharaan tanaman termasuk kegiatan pemupukan.

Hasil penelitian Bryant et al. (2007) terhadap penggunaan teknologi transgenik di Arkansas juga menunjukkan hasil yang sama, bahwa rata-rata petani berperilaku netral terhadap risiko introduksi benih transgenik. Hasil berbeda dikemukakan oleh Liu (2009) di Cina yang justru menemukan bahwa petani secara umum berperilaku menghindari risiko (risk averse) dalam penggunaan input, khususnya pestisida pada tanaman kapas. 
Sebaran perilaku petani terhadap risiko dalam mengalokasikan input produksi dapat dilihat pada Tabel 5.11.

Tabel 5.11. Perilaku Petani Terhadap Risiko Usahatani Kapas di Sulawesi Selatan

\begin{tabular}{cccc}
\hline Kelompok Risiko & Jumlah petani (org) & Persentase $(\%)$ & Rata-rata $\mathrm{K}_{(\mathrm{s})}$ \\
\hline Risk lover & 6 & 4 & 0,09 \\
Risk neutral & 96 & 64 & 0,87 \\
Risk averter & 48 & 32 & 1,26 \\
\hline Total & 150 & 100,00 & \\
\hline
\end{tabular}

Sumber : Analisis Data Primer, 2012

Kesediaan petani sebagai pengambil keputusan untuk memilih atau berperilaku terhadap risiko produksi menurut Ellis (1988), pada dasarnya akan tergantung pada sifat pembawaan psikis dan kepuasan (utilitas) yang diterima petani dari hasil keluaran. Faktor-faktor tersebut akan menentukan perilaku dan strategi petani dalam menghadapi risiko produksi. Perbedaan perilaku petani dalam menghadapi risiko produksi akan mempengaruhi pengambilan keputusan dalam mengalokasikan input-input produksi yang digunakan. Selanjutnya alokasi input yang digunakan akan mempengaruhi tingkat efisiensi dan produktivitas yang diperoleh petani. Apabila dikaitkan dengan tingkat efisiensi teknis yang diperoleh, maka distribusi perilaku petani dapat digambarkan pada Tabel 5.12.

Tabel 5.12. Sebaran Perilaku Petani Beradasarkan Tingkat Efisiensi Teknis Usahatani Kapas Petani Responden di Sulawesi Selatan

\begin{tabular}{ccccc}
\hline $\begin{array}{c}\text { Kelompok } \\
\text { Efisiensi Teknis }\end{array}$ & $\begin{array}{c}\text { Petani } \\
\text { Risk lover }\end{array}$ & $\begin{array}{c}\text { Petani } \\
\text { Risk neutral }\end{array}$ & $\begin{array}{c}\text { Petani } \\
\text { Risk averter }\end{array}$ & Jumlah \\
\hline $0.30-0,39$ & 0 & 1 & 0 & 1 \\
$0,40-0,49$ & 1 & 6 & 4 & 11 \\
$0,50-0,59$ & 0 & 35 & 6 & 41 \\
$0,60-0,69$ & 3 & 22 & 19 & 44 \\
$0,70-0,79$ & 1 & 15 & 9 & 25 \\
$0,80-0,89$ & 1 & 14 & 6 & 21 \\
$0,90-0,99$ & 0 & 3 & 4 & 7 \\
\hline Total & 6 & 96 & 48 & 150 \\
\hline
\end{tabular}

Sumber : Analisis Data Primer, 2012

Berdasarkan tabel di atas terlihat bahwa dari 96 petani yang berperilaku netral (risk neutral), rata-rata berada pada kisaran kelompok petani yang belum efisien, terdapat 64 petani yang memiliki tingkat efisiensi teknis yang lebih kecil 
dari 0,70 . Hanya terdapat 3 petani yang yang sangat efisien $(0,90 \leq \mathrm{TE} \leq 0,99)$, serta 29 petani cukup efisien $(0,70 \leq \mathrm{TE}<0,90)$.

Sebagian besar petani kapas berperilaku netral (risk neutral) terhadap risiko dalam mengalokasikan input produksi. Perilaku ini menunjukkan bahwa jika terjadi kenaikan ragam keuntungan maka petani tidak akan mengimbangi dengan menaikkan atau menurunkan keuntungan yang diharapkan. Kondisi ini kemudian menjelaskan bahwa usahatani kapas yang saat ini diusahakan petani di Sulsel, kebanyakan dilakukan dengan sistem tumpangsari baik dengan jagung maupun dengan kacang-kacangan. Padahal salah satu hambatan produktivitas di lokasi penanaman adalah luasan lahan riil tempat petani mengusahakan tanamannya. Di sisi lain tumpangsari dengan tanaman lainnya justru menjadi penyebab persaingan antara kapas dengan tanaman yang ditumpangsarikan dalam memanfaatkan input-input produksi yang diaplikasikan, sehingga berpotensi menurunkan tingkat produksi kapas yang dihasilkan.

\subsection{Hubungan Antara Efisiensi Teknis dan Perilaku Petani}

Hubungan antara variabel efisiensi teknis dan perilaku petani dalam penelitian ini dianalisis menggunakan analisis korelasi Kendall's tau_b dan Spearman's rho. Analisis ini bertujuan untuk mengetahui keeratan hubungan, arah hubungan dan berarti atau tidaknya hubungan antara kedua variabel. Hasil analisis korelasi antara kedua variabel tersebut dapat dilihat pada tabel 5.13.

Tabel 5.13. Hasil Analisis Korelasi Antara Efisiensi Teknis dan Perilaku Petani Kapas di Sulawesi Selatan

\begin{tabular}{ccc}
\hline Analisis Korelasi & Koefisien Korelasi & Signifikansi \\
\hline Kendall's tau_b & $-0,072$ & 0,365 \\
Spearman's rho & $-0,074$ & 0,367 \\
\hline
\end{tabular}

Sumber : Analisis Data Primer, 2012

Berdasarkan Tabel 5.13 di atas koefisien korelasi pada kedua analisis tersebut hampir sama yakni -0,072 (korelasi Kendall's tau) dan -0,074 (korelasi Spearman's rho). Tanda negatif pada nilai koefisien tersebut menunjukkan hubungan negatif, artinya jika kategori level efisiensi sangat tinggi maka kategori 
perilaku petani menjadi risk averter atau sebaliknya. Keeratan hubungan antara keduanya juga lemah, hal ini dapat dilihat pada nilai koefisien yang semakin mendekati 0 (nol).

Hasil pengujian signifikansi yang diperoleh pada analisis korelasi Kendall's tau_b $=0,365$ dan 0,367 dengan menggunakan korelasi Spearman's rho, kedua nilai tersebut lebih besar dari 0,05 maka hipotesis nol diterima, kesimpulannya tidak ada hubungan yang berarti antara tingkat efisiensi dan perilaku petani kapas yang ada di daerah penelitian. Hubungan atau keterkaitan antara tingkat efisiensi dan perilaku petani dapat dilihat pada Tabel 5.14.

Tabel 5.14. Hubungan Tingkat Efisiensi dan Perilaku Petani Kapas

\begin{tabular}{crrrr}
\hline \multirow{2}{*}{ Tingkat Efisiensi } & \multicolumn{3}{c}{ Perilaku Petani } & \multirow{2}{*}{ Total } \\
\cline { 2 - 4 } & risk averter & risk neutral & risk lover & \\
\hline Belum Efisien & 29 & 64 & 4 & 97 \\
Cukup Efisien & 15 & 29 & 2 & 46 \\
Sangat Efisien & 4 & 3 & 0 & 7 \\
\hline Total & 48 & 96 & 6 & 150 \\
\hline
\end{tabular}

Sumber : Analisis Data Primer, 2012

Berdasarkan tabel di atas, sebagian besar petani yang belum efisien berperilaku risk neutral (64 petani), hal yang sama terjadi pada petani yang cukup efisien, sebagian besar risk neutral, sementara petani yang sangat efisien kebanyakan berperilaku risk averter. Tidak nampak petani yang sangat efisien juga berperilaku risk lover, hal ini menjelaskan tidak adanya hubungan antara tingkat efisiensi yang diperoleh dengan perilaku petani. Terhadap kondisi tersebut, terjadinya inefisiensi pada usahatani kapas ada kemungkinan disebabkan karena sistem kemitraan yang diterapkan pada usahatani kapas yang lebih fokus pada pembinaan secara berkelompok. Sebagaimana dipersyaratkan pada program akselerasi pengembangan kapas, peran kelompok cukup penting. Disamping mengkoordinasi petani, juga membina dan mengurusi kebutuhan agroinput. Sehingga apabila kelompok tani mengalami hambatan internal dan eksternal, maka dampaknya pada penerapan teknologi yang tidak optimal dan efisien, sehingga tidak terjadi peningkatan nilai tambah dari usahatani kapas. Sisi lain yang juga mesti dipertimbangkan adalah kualitas input, karena sesungguhnya 
kualitas input yang baik (utamanya benih), akan mampu berkontribusi terhadap hasil yang diperoleh, sepanjang kualitas lingkungan masih mendukung.

Hasil kajian pada daerah studi ini juga menemukan adanya kecendrungan petani yang berperilaku risk lover yang justru memiliki tingkat efisiensi yang rendah. Petani yang berperilaku risk lover dalam penelitian ini, dapat dimaknai sebagai petani yang mengaplikasikan pupuk Urea (faktor yang paling berpengaruh pada risiko produksi) lebih banyak dari petani lainnya, namun output yang diperoleh justru semakin sedikit. Sehingga kondisi ini dapat dijelaskan dari tidak optimalnya penyerapan unsur hara dari pupuk Urea yang diberikan. Rendahnya tingkat penyerapan tanaman kapas terhadap unsur hara berakibat pada rendahnya produksi serta tidak tercapainya efisiensi yang diharapkan dan penyebabnya ada pada tingkat penerapan teknologi, diantaranya karena aplikasi pemupukan yang terlambat sehingga dilakukan pemupukan secara sekaligus (pemupukan I dan II dilakukan bersamaan). Mundurnya waktu pemupukan secara agronomis, tidak serta merta dapat menggantikan terpenuhinya unsur hara yang dibutuhkan tanaman dengan segera, walaupun diberikan dalam dosis yang lebih banyak. Hal ini disebabkan adanya keterbatasan tanaman dalam menyerap unsur hara sekaligus serta sifat kandungan unsur hara yang mudah hilang karena penguapan dan pencucian, dengan demikian perilaku petani yang menambahkan pupuk yang lebih banyak menjadi tidak efisien. Sumber ketidakefisienannya disebabkan karena peningkatan jumlah aplikasi pupuk serta biaya yang dikeluarkan padahal produksi yang dihasilkan justru tidak meningkat akibat adanya penambahan tersebut. 


\section{ANALISIS DAYA SAING USAHATANI KAPAS}

Hasil empiris dari studi ini mengukur tingkat daya saing sistem usahatani kapas rakyat di Sulsel. Alat analisis yang digunakan adalah Policy Analysis Matrix (PAM), berdasarkan data penerimaan dan biaya produksi yang terbagi dua bagian yaitu harga finansial (privat) dan harga ekonomi (sosial). Perhitungan berdasarkan data budget privat dan budget sosial melalui tabel input output usahatani kapas di Sulsel yang dapat dilihat pada Lampiran 13. Komponen input usahatani kapas rakyat di Sulsel meliputi input tradable seperti benih kapas, Urea, SP-36, NPK (Phonska) dan ZA, masing-masing satuannya adalah kilogram, insektisida (Batador, Marshall dan Comfidor) dengan satuan gram dan herbisida (Bionasa dan Polaris) dalam liter. Sementara tenaga kerja dan modal lainnya digolongkan sebagai input non tradable.

\subsection{Analisis Daya Saing Usahatani Kapas}

Hasil Policy Analysis Matrix (PAM) yang mengukur daya saing melalui pendekatan keunggulan kompetitif dan komparatif serta dampak kebijakan terhadap input maupun output dapat dilihat pada Tabel 6.1.

Tabel 6.1. Policy Analysis Matrix Usahatani Kapas Rakyat di Sulawesi Selatan (Rp/ha)

\begin{tabular}{lrrrr}
\hline \multirow{2}{*}{ Uraian } & \multirow{2}{*}{ Penerimaan } & \multicolumn{2}{c}{ Biaya Input } & \multirow{2}{*}{ Keuntungan } \\
\cline { 3 - 4 } & & Tradable & Non Tradable & \\
\hline Harga Privat & 2.703 .000 & 2.188 .390 & 1.806 .367 & -1.291 .757 \\
Harga Sosial & 5.925 .726 & 2.890 .973 & 1.743 .967 & 1.290 .787 \\
Dampak Divergensi & -3.222 .726 & -702.583 & 62.400 & -2.582 .544 \\
\hline
\end{tabular}

Sumber : Analisis Data Primer, 2012 
Berdasarkan Tabel 6.1 diperoleh nilai sebagai indikator-indikator PAM yang menentukan keunggulan komparatif maupun kompetitif usahatani kapas rakyat di Sulsel, sebagaimana ditunjukkan pada Tabel 6.2.

Tabel 6.2. Indikator-Indikator Policy Analysis Matrix Usahatani Kapas Rakyat di Sulawesi Selatan

\begin{tabular}{lr}
\hline \multicolumn{1}{c}{ Indikator } & \multicolumn{1}{c}{ Nilai } \\
\hline Keuntungan Privat (PP) & -1.291 .757 \\
Rasio Biaya Privat (PCR) & 3,51 \\
Keuntungan Sosial (SP) & 1.290 .787 \\
Rasio Sumberdaya Domestik (DRC) & 0,57 \\
\hline
\end{tabular}

Sumber : Analisis Data Primer, 2012

\section{a. Analisis Keunggulan Kompetitif}

Analisis keunggulan kompetitif digunakan untuk mengukur kelayakan finansial usahatani kapas. Keunggulan kompetitif suatu komoditas dapat dilihat berdasarkan indikator-indikator keuntungan privat (PP) dan rasio biaya privat (PCR). Indikator tersebut menunjukkan tingkat keuntungan secara finansial dan tingkat efisiensi penggunaan sumberdaya. Nilai PP yang diperoleh dari Tabel 6.2 yaitu negatif sebesar Rp 1.291.757 dengan nilai PCR 3,51.

Keuntungan privat diperoleh berdasarkan selisih antara penerimaan dengan biaya input tradable dan domestik per satuan kilogram kapas pada harga aktual. Berdasarkan Tabel 6.1 penerimaan petani secara finansial yaitu $\mathrm{Rp}$ 2.703.000 per hektar sedangkan biaya input sebesar Rp. 3.994 .756 yang terdiri dari biaya tradable sebesar Rp 2.188.390 dan biaya domestik sebesar Rp 1.806.367 sehingga komoditi kapas yang diusahakan petani tidak memiliki keuntungan privat, karena nilainya negatif sebesar Rp 1.291.757 per hektar.

Nilai keuntungan privat yang negatif $(\mathrm{PP}<0)$ menunjukkan bahwa secara finansial usahatani kapas di Sulsel tidak menguntungkan, jika diusahakan sendiri oleh petani tanpa bantuan dari pemerintah. Indikator tersebut menunjukkan bahwa petani sebagai pemilik belum bisa memenuhi kebutuhan keuangannya dengan melakukan usahatani kapas. 
Tingkat efisiensi alokasi sumberdaya dapat diukur dengan menggunakan rasio biaya privat (PCR) yang merupakan rasio antara biaya faktor domestik dengan selisih antara penerimaan dan biaya input tradable pada harga privat. Nilai PCR menunjukkan bahwa setiap 1 dollar US yang diperoleh dari ekspor kapas dibutuhkan biaya input domestik yang lebih besar, yakni sebesar 3,5 dollar. Dengan nilai PCR yang lebih besar dari satu (PCR>1) maka usahatani kapas belum efisien secara finansial dan tidak memiliki keunggulan kompetitif, hal ini disebabkan petani belum mampu membiayai faktor domestiknya pada harga privat.

\section{b. Analisis Keunggulan Komparatif}

Keunggulan komparatif dapat diukur dengan menggunakan nilai keuntungan sosial (SP) dan rasio biaya domestik (DRC) sebagai indikator yang digunakan untuk menganalisis apakah usahatani kapas tetap memiliki daya saing tanpa bantuan pemerintah. Perbedaan analisis keuntungan sosial (SP) dengan keuntungan privat (PP) yakni komponen input dan output dalam keuntungan sosial (SP) dinilai menggunakan harga bayangan.

Keuntungan sosial merupakan selisih antara penerimaan dengan biaya input pada saat persaingan sempurna dan tidak ada efek divergensi baik kebijakan pemerintah maupun distorsi pasar. Keuntungan sosial diperoleh dari selisih penerimaan Rp 5.925.726 per hektar dengan biaya input tradable sebesar Rp 2.890.973 dan biaya input domestik sebesar Rp 1.743.967 sehingga diperoleh keuntungan Rp 1.290.787. Keuntungan sosial yang positif ( $\mathrm{SP}>0$ ) menunjukkan bahwa usahatani kapas menguntungkan secara ekonomi dan layak untuk diusahakan.

Selain keuntungan sosial, keunggulan komparatif bisa dilihat dari indikator DRC yang merupakan rasio antara biaya domestik dengan selisih penerimaan dikurangi biaya asing pada harga tanpa intervensi pemerintah (harga bayangan). Suatu usahatani akan efisien secara ekonomi jika DRC diperoleh kurang dari satu $(\mathrm{DRC}<1)$, semakin kecil nilai DRC maka keunggulan komparatif 
yang dimiliki semakin besar dan jika DRC lebih dari satu (DRC $>1)$ menunjukkan pemborosan sumberdaya domestik. Nilai DRC yang diperoleh adalah 0,57 , nilai tersebut mengindikasikan bahwa usahatani kapas efisien secara ekonomi dan memiliki keunggulan komparatif. Dengan nilai DRC yang diperoleh maka komoditas kapas lebih efisien apabila diproduksi di dalam negeri dibandingkan impor atau memiliki peluang ekspor yang tinggi.

Secara umum hasil ini mengkonfirmasi bahwa usahatani kapas tidak menguntungkan secara finansial dan tidak memiliki keunggulan kompetitif bila diusahakan tanpa adanya intervensi dari pemerintah berupa kebijakan, khususnya bantuan input-input produksi. Walaupun secara ekonomi usahatani kapas masih menguntungkan dan memiliki keunggulan komparatif, Namun hal ini lebih diakibatkan karena perbedaan harga dunia/internasional yang menyebabkan keuntungan yang diperoleh lebih besar.

Terkait perlunya intervensi pemerintah terhadap usahatani kapas, tidak hanya terjadi di lokasi studi. Di negara penghasil kapas lainnya, seperti India dan Syria juga menunjukkan hal yang sama (Mohanty et al, 2003; dan Alabdullah dan Nuppenau, 2010), hasil penelitian keduanya menunjukkan bahwa pada kedua negara penghasil kapas tersebut tanpa adanya intervensi pemerintah terhadap aktivitas usahatani kapas, ada kemungkinan areal kapas yang ada di negara tersebut akan berubah ke komoditi lain yang lebih menguntungkan.

Dukungan pemerintah dalam pengembangan kapas dapat berupa kebijakan harga kapas yang menarik, pemberian bantuan saprodi (benih, pupuk, dan pestisida) untuk meringankan biaya usaha tani kapas bagi petani, serta pembaruan sistem penyuluhan yang belum optimal. Saat ini, bentuk intervensi terhadap usahatani kapas oleh pemerintah diwujudkan dalam bentuk program akselerasi, yang diantaranya diupayakan melalui pemberian bantuan input untuk mendukung pengembangan usahatani kapas. 


\subsection{Daya Saing Kapas Melalui Akselerasi Pengembangan Kapas Rakyat.}

Akselerasi pengembangan kapas rakyat yang dilakukan di Sulsel sebagaimana dijelaskan pada bagian awal bertujuan untuk mempercepat perluasan areal dan peningkatan produksi melalui pemberian bantuan berupa $100 \%$ benih dan $25 \%$ sarana produksi lainnya. Berdasarkan ketentuan pemerintah, besarnya bantuan input fisik yang diberikan untuk per hektar adalah : benih kapas $6 \mathrm{~kg}$, Urea $50 \mathrm{~kg}$, SP $3650 \mathrm{~kg}$, NPK $50 \mathrm{~kg}$, ZA $50 \mathrm{~kg}$, herbisida 2 liter dan insektisida (padat) 100 gram (Ditjenbun, 2012).

Berbeda dengan analisis sebelumnya yang tidak memperhitungkan besarnya bantuan pemerintah. Hasil Policy Analysis Matrix berikut dilakukan dengan mempertimbangkan besaran input yang diberikan sebagai bantuan sosial pada petani yang menanam kapas, sehingga hasil perhitungan yang diperoleh merupakan gambaran usahatani sesungguhnya pada saat studi ini dilaksanakan. Hasil analisis PAM yang mempertimbangkan adanya bantuan input pada usahatani kapas diuraikan pada Tabel 6.3.

Tabel 6.3. Policy Analysis Matrix Usahatani Kapas Rakyat di Sulsel dengan Memperhitungkan Bantuan Input (Rp/ha)

\begin{tabular}{lrrrr}
\hline \multirow{2}{*}{ Uraian } & \multirow{2}{*}{ Penerimaan } & \multicolumn{2}{c}{ Biaya Input } & \multirow{2}{*}{ Keuntungan } \\
\cline { 3 - 4 } & & \multicolumn{1}{c}{ Tradable } & Non tradable & \\
\hline Harga Sosial & 2.703 .000 & 370.238 & 1.806 .367 & 526.395 \\
Harga Privat & 5.925 .726 & 693.320 & 1.743 .967 & 3.488 .440 \\
Dampak Divergensi & -3.222 .726 & -323.081 & 62.400 & -2.962 .045 \\
\hline Sunnnnn
\end{tabular}

Berbeda dengan hasil yang diperoleh pada Tabel 6.1 sebelumnya, Tabel 6.3 menunjukkan hasil berdasarkan perhitungan input yang telah di kurangkan dengan besarnya input yang menjadi bantuan pemerintah (Lampiran 15). Perubahan yang terjadi pada input tradable menyebabkan perubahan nilai keuntungan yang di peroleh, sehingga terjadi perubahan terhadap indikatorindikator daya saing dan dampak kebijakan. 


\subsubsection{Analisis Daya Saing}

Berdasarkan hasil analisis PAM (Lampiran 16), diperoleh indikatorindikator berkaitan dengan daya saing kapas berikut ini.

Tabel 6.4. Indikator-Indikator Policy Analysis Matrix Pada Usahatani Kapas Mempertimbangkan Bantuan Input

\begin{tabular}{lr}
\hline Indikator & Nilai \\
\hline Keuntungan Privat (PP) & 526.395 \\
Rasio Biaya Privat (PCR) & 0,77 \\
Keuntungan Sosial (SP) & 3.488 .440 \\
Rasio Sumberdaya Domestik (DRC) & 0,33 \\
\hline
\end{tabular}

Sumber : Analisis Data Primer, 2012

\section{a. Analisis Keunggulan Kompetitif}

Berdasarkan indikator keuntungan privat $(\mathrm{PP})$ dan rasio biaya privat (PCR). Indikator tersebut menunjukkan tingkat keuntungan secara finansial dan tingkat efisiensi penggunaan sumberdaya. Nilai PP yang diperoleh dari perhitungan nilai tersebut adalah Rp 526.395 dan PCR 0,77. Nilai keuntungan privat yang positif $(\mathrm{PP}>0)$ menunjukkan bahwa secara finansial usahatani kapas di Sulsel menguntungkan.

Tingkat efisiensi alokasi sumberdaya dapat diukur dengan menggunakan rasio biaya privat (PCR) menunjukkan bahwa setiap 1 dollar US yang diperoleh dari ekspor kapas dibutuhkan biaya input domestik yang lebih kecil, yakni sebesar 0,77. Dengan nilai PCR kurang dari satu $(\mathrm{PCR}<1)$ maka usahatani kapas telah efisien secara finansial dan memiliki keunggulan kompetitif karena pada kondisi tersebut petani telah dianggap mampu membiayai faktor domestiknya pada harga privat.

Tabel 6.5. Sebaran Keunggulan Kompetitif Usahatani Kapas di Sulawesi Selatan

\begin{tabular}{rcc}
\hline Nilai PCR & Jumlah Petani & Persentase $(\%)$ \\
\hline $0,00-0,49$ & 20 & 13,33 \\
$0,50-0,99$ & 108 & 72,00 \\
$\geq 1,00$ & 22 & 14,67 \\
\hline Total & 150 & 100,00
\end{tabular}

Sumber : Analisis Data, 2012 
Hasil yang diperoleh berdasarkan Tabel 6.5 memperlihatkan bahwa usahatani kapas yang dilakukan oleh petani telah menunjukkan adanya keunggulan kompetitif, terdapat $85,33 \%$ usahatani kapas yang dilakukan petani memiliki nilai PCR dibawah 1 dan hanya terdapat 22 petani yang dalam usahataninya masih belum memiliki keunggulan kompetitif (PCR>1). Namun yang perlu diperhatikan bahwa nilai keuntungan privat masih terlalu rendah sementara nilai PCR yang diperoleh juga masih mendekati $1(0,77)$. Jika dilihat pada aktivitas budidaya yang dilakukan petani hasil yang diperoleh sangat dipengaruhi oleh besarnya produksi serat kapas yang dihasilkan. Menurut Rachman (2007) walaupun harga serat kapas hasil petani lebih tinggi dibandingkan harga gabah dan jagung, tetapi karena produktivitasnya rendah yaitu rata-rata hanya mencapai $500 \mathrm{~kg} / \mathrm{ha}$ maka pendapatan petani dari kapas juga lebih rendah dibandingkan padi atau jagung yang hasil produksinya dapat mencapai lebih dari 4 ton/ha.

\section{b. Analisis Keunggulan Komparatif}

Keunggulan komparatif menggunakan nilai keuntungan sosial (SP) dan rasio biaya domestik (DRC). Keuntungan sosial (SP) diperoleh dari selisih penerimaan Rp 5.925.726 per hektar dengan biaya input tradable sebesar Rp 693.320 dan biaya input domestik sebesar Rp 1.743 .967 sehingga diperoleh keuntungan $\mathrm{Rp}$ 3.488.440. Keuntungan sosial yang positif ( $\mathrm{SP}>0$ ) menunjukkan bahwa usahatani kapas menguntungkan secara ekonomi sehingga layak untuk diusahakan. Sementara itu nilai DRC yang diperoleh dengan memperhitungkan besaran bantuan input adalah 0,33. Hal ini mengindikasikan bahwa usahatani kapas efisien secara ekonomi dan memiliki keunggulan komparatif.

Tabel 6.6. Sebaran Keunggulan Komparatif Usahatani Kapas di Sulawesi Selatan

\begin{tabular}{rrc}
\hline Nilai DRC & Jumlah Petani & Persentase (\%) \\
\hline $0,00-0,49$ & 143 & 95,33 \\
$0,50-0,99$ & 5 & 3,33 \\
$\geq 1,00$ & 2 & 1,33 \\
\hline Total & 150 & 100,00
\end{tabular}

Sumber : Analisis Data, 2012 
Berdasarkan Tabel 6.6 dapat dilihat bahwa hampir semua usahatani kapas yang dilakukan oleh petani telah memiliki kemampuan bersaing secara komparatif, bahkan sebagian besar usahatani kapas $(95,33 \%)$ memiliki nilai DRC yang semakin mendekati 0 .

\subsubsection{Analisis Dampak Kebijakan Pemerintah Terhadap Output}

Kebijakan pemerintah terhadap output bisa dilihat dari dua nilai yaitu transfer output (OT) dan koefisien proteksi output nasional (NPCO). Transfer output adalah selisih dari penerimaan privat dan penerimaan sosial. Nilai OT yang diperoleh adalah negatif $(\mathrm{OT}<0)$ yaitu $\mathrm{Rp} 3.222 .726$ yang mengindikasikan bahwa tidak ada insentif konsumen terhadap produsen, sehingga harga yang dibayarkan oleh konsumen lebih rendah dari seharusnya atau terjadi transfer output dari produsen ke konsumen. Dengan kata lain, tidak ada subsidi output yang menyebabkan harga sosial lebih tinggi daripada harga privat. Harga kapas domestik yaitu Rp 4.250 sedangkan harga dunia sebesar Rp 9.317. Perbedaan harga tersebut menjadikan penerimaan produsen menjadi lebih rendah pada saat ada kebijakan pemerintah (harga aktual).

Indikator lain yang bisa digunakan untuk melihat dampak kebijakan pemerintah yaitu koefisien proteksi output nasional (NPCO) yang menunjukkan tingkat proteksi pemerintah terhadap output. Nilai NPCO yang diperoleh yaitu 0,46 (NPCO<1) yang menunjukkan bahwa harga domestik lebih rendah dari harga dunia. Hal ini juga mengindikasikan bahwa kebijakan pemerintah belum berjalan efektif sehingga terjadi pengurangan penerimaan petani.

Petani hanya memperoleh $46 \%$ dari harga yang seharusnya yang menyebabkan petani tidak memperoleh insentif untuk meningkatkan produksi. Dengan tidak adanya transfer output dari konsumen ke produsen maka menyebabkan harga yang diterima oleh konsumen lebih rendah dari yang seharusnya dan terjadi kebijakan pemerintah yang melindungi konsumen domestik. 
Tabel 6.7. Indikator - Indikator Policy Analysis Matrix Usahatani Kapas di Sulawesi Selatan Mempertimbangkan Bantuan Input

\begin{tabular}{ll}
\hline Indikator & Nilai \\
\hline Transfer Output (OT) & -3.222 .726 \\
Koefisien Proteksi Output Nominal (NPCO) & 0,46 \\
\hline Sumber: Analisi Dat Primer, 2012
\end{tabular}

Sumber : Analisi Data Primer, 2012

\subsubsection{Analisis Dampak Kebijakan Pemerintah Terhadap Input}

Kebijakan pemerintah terhadap input bisa berupa subsidi dan hambatan impor untuk melindungi produsen, untuk mengetahui adanya insentif pemerintah terhadap input bisa dilihat dari indikator transfer input (IT), transfer faktor (FT) dan koefisien proteksi input nasional (NPCI).

Nilai transfer input merupakan selisih biaya input tradable privat dan sosial. Jika nilai IT positif (IT $>0$ ), maka harga sosial input asing lebih tinggi dan produsen membayar lebih mahal. Nilai IT yang diperoleh petani di Sulsel yaitu negatif $\operatorname{Rp} 323.081$ yang menunjukkan adanya subsidi pemerintah terhadap input asing, sehingga produsen tidak membayar penuh untuk membeli input.

Transfer faktor menunjukkan besarnya subsidi terhadap input non tradable dan diperoleh dari selisih biaya input non tradable privat dan sosial. Jika nilai $\mathrm{TF}$ positif $(\mathrm{TF}>0)$ maka terjadi subsidi negatif dan nilai $\mathrm{TF}$ negatif $(\mathrm{TF}<0)$ maka terjadi subsidi positif. Nilai yang diperoleh yaitu Rp 62.840 per kilogram mengindikasikan bahwa terjadi subsidi negatif dari pemerintah.

Koefisien proteksi input nominal (NPCI) adalah rasio dari biaya input tradable privat dan sosial, merupakan indikator yang menunjukkan tingkat proteksi pemerintah terhadap harga input domestik. Dari hasil yang didapat NPCI kurang dari satu $(\mathrm{NPCI}<1)$ yaitu 0,53 . Kebijakan pemerintah bersifat protektif terhadap input asing dan produsen menerima subsidi atas input asing sehingga produsen membeli dengan harga yang lebih murah. Petani kapas menerima harga input yang lebih murah sebesar 53\% dari yang seharusnya. 
Tabel 6.8. Indikator - Indikator Policy Analysis Matrix Usahatani Kapas di Sulawesi Selatan Mempertimbangkan Bantuan Input Terhadap Input

\begin{tabular}{lr}
\hline Indikator & Nilai \\
\hline Transfer Input (IT) & -323.081 \\
Transfer faktor (TF) & 62.400 \\
Koefisien Proteksi Input Nominal (NPCI) & 0,53 \\
\hline
\end{tabular}

Sumber : Analisi Data Primer, 2012

\subsubsection{Analisis Dampak Kebijakan Pemerintah Terhadap Input-Output}

Kebijakan terhadap input dan output merupakan gabungan antara kebijakan input dan kebijakan output. Indikator dampak kebijakan inputoutput bisa dilihat dari Koefisien Proteksi Efektif (EPC), Nilai Rasio Subsidi bagi Produsen (SRP), Koefisien Keuntungan (PC) dan Transfer Bersih (NT).

Koefisien proteksi efektif adalah rasio antara penerimaan privat dikurangi biaya input tradable dengan penerimaan sosial dikurangi biaya input tradable dan menggambarkan sejauh mana kebijakan pemerintah melindungi atau menghambat produksi domestik. Nilai EPC yang diperoleh yaitu $0,43($ EPC $<1)$ menggambarkan kebijakan terhadap output maupun subsidi input bersifat menghambat (tidak efektif) dan tidak memberikan insentif terhadap petani untuk berproduksi.

Transfer bersih (NT) merupakan selisih antara keuntungan privat dan keuntungan sosial (asumsi pasar persaingan sempurna) yang menggambarkan dampak kebijakan pemerintah terhadap penerimaan apakah menguntungkan atau merugikan. Nilai NT yang diperoleh bernilai negatif yaitu Rp 2.650.129 yang menunjukkan bahwa kebijakan pemerintah tidak memberikan insentif untuk meningkatkan produksi.

Pengaruh kebijakan secara keseluruhan dicerminkan oleh koefisien keuntungan yang menyebabkan keuntungan privat berbeda dengan keuntungan sosial dan diperoleh dari rasio penerimaan privat dengan sosial. Nilai PC yang diperoleh yaitu 0,15 yang mengindikasikan bahwa keuntungan yang diperoleh petani hanya $15 \%$ dan kehilangan $85 \%$ keuntungan yang seharusnya. 
Tabel 6.9. Indikator - Indikator Policy Analysis Matrix Usahatani Kapas di Sulawesi Selatan Mengenai Dampak Kebijakan Terhadap InputOutput

\begin{tabular}{lr}
\hline \multicolumn{1}{c}{ Indikator } & Nilai \\
\hline Koefisien Proteksi Efektif (EPC) & 0,45 \\
Transfer Bersih (NT) & -2.962 .045 \\
Koefisien Keuntungan (PC) & 0,15 \\
Rasio Subsidi bagi Produsen (SRP) & $-0,50$ \\
\hline
\end{tabular}

Sumber : Analisi Data Primer, 2012

Nilai rasio subsidi bagi produsen (SRP) merupakan indikator yang menunjukkan tingkat penambahan dan pengurangan penerimaan atas pengusahaan suatu komoditas karena adanya kebijakan pemerintah. Berdasarkan Tabel 6.9, nilai SRP bernilai negatif, yakni sebesar 0,50. Nilai ini secara umum berarti kebijakan pemerintah terhadap input dan output merugikan petani, karena petani diharuskan membayar lebih tinggi dari biaya imbangannya (opportunity cost) untuk berproduksi sebesar $50 \%$.

\subsection{Analisis Sensitivitas}

Analisis sensitivitas digunakan untuk melihat dampak kebijakan terhadap input dan output yang mempengaruhi keuntungan, daya saing suatu komoditi dan nilai rasio dalam analisis PAM serta menggunakan asumsiasumsi kondisi yang mungkin terjadi dalam usahatani kapas. Menurut Yao (1997) dalam Mohanty et al, (2002), analisis sensitivitas dilakukan untuk menguji apakah terjadi perubahan substansial yang diakibatkan perubahan asumsi-asumsi dasar. Analisis sensitivitas perlu dilakukan karena analisis metode PAM merupakan analisis yang bersifat statis, yakni hanya memberlakukan satu tingkat harga berlaku pada tahun bersangkutan.

Pada studi ini analisis sensitivitas didasarkan pada tiga asumsi perubahan yakni perubahan yang disebabkan karena perubahan harga CIF kapas, perubahan pajak masuk, serta perubahan harga input dan output. Perubahan indikator yang terjadi jika dilakukan analisis tersebut meliputi keuntungan privat (PP), 
keuntungan sosial (SP), rasio biaya privat (PCR) dan rasio biaya domestik (DRC). Nilai untuk indikator tersebut bisa dilihat pada Tabel 6.10.

Tabel 6.10. Analisis Sensitivitas Usahatani Kapas Bila Terjadi Perubahan

\begin{tabular}{lrccc}
\hline \multirow{2}{*}{ Uraian } & \multicolumn{4}{c}{ Indikator } \\
\cline { 2 - 5 } & PP $(\mathrm{Rp} / \mathrm{ha})$ & PCR & SP $(\mathrm{Rp} / \mathrm{ha})$ & DRC \\
\hline Tanpa bantuan & -1.291 .757 & 3,51 & 1.290 .787 & 0,57 \\
Bantuan input & 526.395 & 0,77 & 3.488 .440 & 0,33 \\
Skenario 1 & 526.395 & 0,77 & 4.704 .993 & 0,27 \\
Skenario 2 & 526.395 & 0,77 & 3.760 .088 & 0,32 \\
Skenario 3 & 944.941 & 0,65 & 3.760 .088 & 0,32 \\
Skenario 4 & 1.003 .395 & 0,64 & 3.731 .831 & 0,32 \\
\hline Skn
\end{tabular}

Sumber : Analisis Sensitivitas Harga, 2012

Keterangan :

- Tanpa bantuan $\quad$ : Usahatani kapas dilaksanakan tanpa memperhitungkan bantuan input

- Bantuan input : Usahatani kapas dengan bantuan input sesuai pelaksanaan program

- Skenario 1 : Harga CIF kapas dinaikkan 20\%

- Skenario $2 \quad:$ Pajak diberlakukan sebesar 15\%

- Skenario 3 : Harga pupuk Urea dinaikkan 10\%, pupuk lainnya dinaikkan 30\% dengan harga kapas berbiji dinaikkan $15 \%$

-Skenario $4 \quad$ : Harga dunia naik 4\%

Berdasarkan hal tersebutnya perubahan yang terjadi adalah nilai PCR menjadi 0,65 sementara nilai DRC 0,32.

\section{a) Terhadap hasil Perubahan Harga CIF Kapas}

Perubahan harga CIF menjadi 20\% didasarkan hasil penelitian yang pernah dilakukan oleh Mohanty et al. (2002). Perubahan nilai CIF kapas, hanya akan berpengaruh terhadap harga sosial kapas dan harga sosial pupuk. Apabila terjadi peningkatan harga CIF maka akan terjadi peningkatan keunggulan komparatif. Artinya terjadi peningkatan penerimaan yang seharusnya diterima petani karena perubahan harga sosial. Berdasarkan Tabel 6.10, besarnya keuntungan sosial (SP), meningkat menjadi Rp 4.704.993 dari kondisi awal Rp 3.488.440 yang diasumsikan petani melaksanakan usahatani sesuai rancangan program Akselerasi Pengembangan Kapas di Sulsel. Keunggulan komparatif juga ditunjukkan oleh nilai DRC yang semakin kecil mendekati nol, yakni 0,27 (DRC< 1). Disisi lain perubahan harga CIF, tidak peka terhadap perubahan nilai keuntungan privat dan nilai PCR, walaupun berdasarkan nilai yang ada 
mengindikasikan bahwa usahatani kapas rakyat memiliki keunggulan kompetitif dan komparatif jika terjadi peningkatan harga CIF kapas.

\section{b) Perubahan Nilai Pajak}

Aturan nilai pajak yang diberlakukan dalam kajian ini sebesar $10 \%$ dari harga FOB, mengikuti besaran pajak yang diberlakukan untuk barang yang berasal dari Asia Non-Asean. Jika diamsusikan nilai pajak mengalami perubahan seperti dengan besaran pajak yang berasal dari Eropa, Amerika dan Afrika, yakni 15\%. Maka berdasarkan Tabel 6.10, apabila dibandingkan dengan asumsi awal (usahatani dengan subsidi), sistem usahatani kapas masih memiliki keunggulan komparatif yang ditunjukkan oleh peningkatan nilai keuntungan sosial (SP) dan nilai DCR yang kurang dari satu $(\mathrm{DRC}<1)$.

\section{c) Perubahan Harga Input dan Output.}

Perubahan harga input, khususnya pupuk didasarkan pada Peraturan Menteri Pertanian No. 32/2010 yang menyatakan bahwa kenaikan harga eceran tertinggi untuk pupuk Urea sebesar $10 \%$ dan pupuk non Urea rata-rata $30 \%$. Sementara perubahan harga output, mengacu pada perubahan harga yang selama ini diberlakukan oleh pemerintah dalam mendukung Program Akselerasi Kapas. Saat studi dilakukan, harga serat kapas yang diberlakukan sebesar Rp 4.250 per kilogram dan setiap tahunnya mengalami peningkatan sebesar Rp 250/kg. * Maka asumsi yang dipakai dalam perubahan mengambil nilai perubahan sebesar Rp 750/kg, sehingga harga output menjadi Rp 5.000/kg.

Berdasarkan Tabel 6.10 peningkatan harga pupuk dan output, menyebabkan terjadinya peningkatan nilai Keuntungan Privat (PP) menjadi Rp 944.941 dari kondisi awal yang hanya Rp 526.395, dengan nilai PCR yang menurun dari 0,77 menjadi 0,65 (PRC<1). Keuntungan Sosial (SP) juga mengalami peningkatan dan nilai DRC tetap lebih kecil dari satu $(\mathrm{DRC}<1)$. Hasil

*) Setiap tahun pemerintah/Kementerian Pertanian melakukan rapat koordinasi dan evaluasi pelaksanaan program akselerasi kapas. Salah satu yang ditetapkan dalam rapat koordinasi adalah harga pembelian serat kapas untuk musim tanam berikutnya. 
ini mengindikasikan bahwa perubahan harga input, khususnya harga pupuk yang dinaikkan dan diikuti kenaikan harga output, masih memberikan keuntungan privat (PP) dan keuntungan sosial (SP) serta nilai PCR dan DCR yang masingmasing berada di bawah satu. Hal ini berarti sistem usahatani kapas memiliki keunggulan kompetitif dan komparatif, sebagai akibat adanya perubahan.

Hasil di atas tidak jauh berbeda jika dilakukan analisis sensitivitas berdasarkan harga dunia. Harga dunia yang dapat dijadikan patokan adalah dampak dari dicabutnya subsidi ekspor kapas negara maju, khususnya Amerika Serikat. Hasil simulasi yang dilaporkan oleh Sudaryanto dan Hadi (2007) pencabutan subsidi ekspor negara maju akan berdampak pada peningkatan harga dunia sebesar 3,1-4,8\% atau rata-rata mengalami kenaikan harga $4 \%$. analisis sensitivitas dengan menggunakan beberapa skenario di atas, maka skenario yang berpeluang memberi daya saing terbaik usahatani kapas adalah jika harga pembelian serat kapas dinaikkan menjadi Rp 5.000 walaupun pada saat yang sama harga pupuk dinaikkan sesuai Peraturan Menteri Pertanian. Kondisi ini bisa terjadi karena kendala terbesar usahatani kapas adalah produktivitasnya. Sehingga peningkatan penerimaan hanya bisa ditingkatkan melalui perbaikan harga, sementara dari sisi pembiayaan walaupun harga yang ditingkatkan menyebabkan peningkatan total biaya, namun petani pada saat yang sama tidak melakukan peningkatan penggunaan jumlah input yang dimaksudkan sebagai upaya efisiensi dan mencegah kegagalan produksi karena kualitas benih yang digunakan belum sepenuhnya sesuai dengan yang diharapkan.

\subsection{Hubungan Antara Efisiensi Teknis dan Daya Saing}

Hubungan antara variabel efisiensi teknis dan daya saing usahatani kapas dalam penelitian ini dianalisis menggunakan analisis korelasi Kendall's tau_b dan Spearman's rho. Hasil analisis korelasi antara kedua variabel tersebut dapat dilihat pada tabel 6.11. 
Tabel 6.11. Hasil Analisis Korelasi Antara Efisiensi Teknis dan Daya Saing Petani Kapas di Sulawesi Selatan

\begin{tabular}{ccc}
\hline Analisis Korelasi & Koefisien Korelasi & Signifikansi \\
\hline Kendall's tau_b & $0,261^{* * *}$ & 0,001 \\
Spearman's rho & $0,266^{* *}$ & 0,001 \\
\hline
\end{tabular}

Sumber : Analisis Data Primer, 2012

Keterangan : $\left.{ }^{* *}\right)$ signifikan pada taraf 0,01

Berdasarkan Tabel 6.11 di atas koefisien korelasi pada kedua analisis tersebut masing masing 0,261 (korelasi Kendall's tau_b) dan 0,266 (korelasi Spearman's rho). Tanda positif pada nilai koefisien tersebut menunjukkan hubungan yang positif, artinya jika kategori level efisiensi sangat tinggi maka kategori usahatani kapas memiliki daya saing (kompetitif), sebaliknya tidak berdaya saing jika efisiensi teknis usahatani yang diperoleh rendah (inefisien).

Hasil pengujian signifikansi yang dilakukan diperoleh nilai 0,001, yang berarti lebih kecil dari 0,05. Dengan demikian pengujian signifikansi pada penelitian ini menyimpulkan adanya hubungan yang berarti antara tingkat efisiensi dan daya saing usahatani kapas di daerah penelitian.

Tabel 6.12. Hubungan Tingkat Efisiensi dan Daya Saing Usahatani Kapas

\begin{tabular}{crrr}
\hline \multirow{2}{*}{ Tingkat Efisiensi } & \multicolumn{2}{c}{ Daya Saing } & \multirow{2}{*}{ Total } \\
\cline { 2 - 3 } & kompetitif & non kompetitif & 97 \\
Belum Efisien & 76 & 21 & 46 \\
Cukup Efisien & 45 & 1 & 7 \\
Sangat Efisien & 7 & 0 & 150 \\
\hline Total & 128 & 22 &
\end{tabular}

Sumber : Analisis Data Primer, 2012

Berdasarkan Tabel 6.12, usahatani kapas yang kompetitif berada pada semua tingkatan efisiensi, sementara usahatani kapas yang tidak kompetitif, hampir seluruhnya adalah juga petani yang belum efisien. Hal ini mengkonfirmasi hasil analisis di atas yang menyimpulkan adanya keeratan hubungan, yang dapat dimaknai bahwa semakin efisien usahatani kapas, semakin kompetitif. Efisiensi merupakan salah satu akar penentu daya saing. Suatu produk yang memiliki daya saing yang tinggi salah satunya karena produk tersebut mampu diproduksi secara 
efisien. Produksi yang efisien akan menyebabkan penurunan biaya produksi sehingga akan meningkatkan keuntungan yang akan diperoleh.

Dengan demikian untuk meningkatkan daya saing usahatani kapas, diperlukan upaya keras untuk melakukan terobosan teknologi yang mampu mencapai tingkat efisiensi yang maksimal, mengingat dalam kajian ini efisiensi kapas rakyat masih rendah. Menurut Sulystyowati dan Sahid (2005) daya saing kapas lebih lemah dibandingkan komoditi lainnya disebabkan oleh besarnya kehilangan hasil kapas di tingkat petani sehingga hanya mampu mencapai $50 \%$ dari potensi hasil varietas-varietas kapas yang dianjurkan, di samping itu tingkat adopsi teknologi yang diintroduksikan oleh petani juga rendah. Jadi kunci pencapaian daya saing pada usahatani kapas adalah produktivitas yang diharapkan dapat meningkatkan penerimaan petani. Dengan penerimaan yang tinggi dari usahatani kapas maka petani dapat bertahan dan tidak terpengaruh dengan komoditas tanaman lainnya yang juga potensial memanfaatkan lahan usahatani kapas. 


\section{PENUTUP}

\subsection{Kesimpulan}

Berdasarkan hasil kajian yang dilakukan, dapat diambil kesimpulan sebagai berikut:

a. Usahatani kapas yang dilakukan petani di Sulawesi Selatan saat ini tergolong belum efisien (inefisien), baik secara teknis, alokatif maupun ekonomi. Faktorfaktor yang berpengaruh positif terhadap produksi kapas adalah luas lahan, pemberian jumlah Urea, jumlah SP-36, pemakaian insektisida, penyemprotan herbisida dan pemanfaatan tenaga kerja. Faktor yang berpengaruh positif terhadap inefisiensi usahatani kapas adalah umur petani.

b. Petani kapas di Sulawesi Selatan dalam menjalankan usahataninya berperilaku netral (risk neutral) terhadap pengalokasian input. Hal ini menunjukkan usahatani kapas yang saat ini dijalani oleh petani tidak terpengaruh oleh pilihan risiko dalam pengambilan keputusan.

c. Usahatani kapas di Sulawesi Selatan yang diusahakan melalui program akselerasi pengembangan kapas rakyat menguntungkan, baik secara finansial maupun ekonomi, serta mempunyai keunggulan kompetitif maupun komparatif. Skenario kenaikan harga pupuk Urea 10\% dan 30\% untuk pupuk lainnya yang diikuti kenaikan pembelian harga kapas berbiji 15\% memberikan tingkat perubahan daya saing yang terbaik.

d. Tidak terdapat hubungan yang berarti antara tingkat efisiensi yang dicapai dengan perilaku petani terhadap risiko. Sementara terhadap daya saing, diketemukan adanya hubungan yang berarti antara tingkat efisiensi dan daya saing dengan arah hubungan yang positif. 


\subsection{Implikasi Kebijakan}

Berdasarkan temuan hasil yang diperoleh di lapangan, maka usahatani kapas dapat ditingkatkan pengelolaannya melalui beberapa kebijakan yang bersifat dasar dan operasional. Kebijakan yang bisa diupayakan antara lain sebagai berikut :

a. Peningkatan efisiensi produksi melalui percepatan pertumbuhan produksi kapas dan peningkatan pendapatan petani dengan melakukan beberapa upaya strategis, diantaranya; perluasan areal, manajemen pemupukan yang rasional, serta aplikasi pengendalian hama/penyakit dan gulma sesuai dengan rekomendasi. Pada tataran operasionalnya petani perlu didorong untuk meningkatkan luas panen baik dengan cara perluasan lahan penanaman ataupun penerapan sistem monokultur. Saat ini luas lahan petani untuk kapas rata-rata 0,76 ha, sehingga bila lahan dioptimalkan seluruhnya untuk kapas, petani diharapkan dapat meningkatkan luas tanamnya menjadi rata-rata 1 ha dengan mengubah pola tanamnya dari tumpangsari menjadi monokultur. Manajemen pemupukan juga perlu mempertimbangkan kebutuhan tanaman di lokasi penanaman, minimal untuk kondisi pertanaman saat ini, pemupukan Urea masih dapat ditingkatkan hingga $150 \mathrm{~kg} / \mathrm{ha}$ serta SP-36 disesuaikan dengan rekomendasi saat ini sebesar $100 \mathrm{~kg} / \mathrm{ha}$, peningkatan ini sesuai dengan tingkat capaian efisiensi saat ini yang juga disesuaikan dengan hasil uji coba lapang sebelumnya saat varietas kapas (HSC 138) ini di uji multilokasi di beberapa wilayah pengembangan di Sulsel serta kondisi pertanaman daerah asal benih tersebut (Cina), yang penggunaan pupuknya bisa mencapai dua kali lebih besar dari jumlah penggunaan yang diterapkan di Sulsel (Indonesia). Dari sisi ketahanan tanaman terhadap hama dan penyakit serta persaingan tanaman kapas dengan gulma, dosis insektisida dan herbisida yang dianjurkan secara umum telah ditunjukkan di label kemasan produk insektisida dan herbisida yang digunakan, sehingga dalam aplikasinya sangat dianjurkan dengan prinsip kehati-hatian, mengutamakan pengendalian saat serangan hama atau persaingan gulma mulai melampaui ambang ekonomi. 
b. Sesuai yang dapat diungkapkan dalam studi ini bahwa semakin tua umur petani semakin efisien usahataninya, maka untuk mencapai efisiensi yang maksimal perlu diperkenalkan teknologi kapas yang lebih praktis dan mudah untuk diaplikasikan oleh petani. Umur petani yang meningkat membuatnya lebih matang dalam berusahatani di tambah lagi rata-rata petani kapas berada pada kisaran umur produktif, hal ini pada akhirnya akan membuat petani secara mental memiliki keinginan untuk menerapkan inovasi-inovasi baru yang akan berdampak terhadap peningkatan efisiensi kerja petani.

c. Terkait dengan perilaku netral petani terhadap risiko perlu dilakukan upaya untuk mengoptimalkan peran penyuluhan dari pihak perusahaan mitra/ pengelola dan dinas terkait (Dinas Perkebunan), melalui sistem kemitraan yang saling menguntungkan, agar petani lebih memahami tujuan pelaksanaan program akselerasi kapas sebagai bagian dari pemenuhan kebutuhan industri dalam negeri melalui peningkatan produksi. Kegiatan yang saat ini sudah berjalan adalah bimbingan teknis disertai dengan pendampingan dari tenaga lapang yang ditugaskan secara khusus dari Dinas Perkebunan Provinsi. Namun kegiatan ini masih mengalami kendala karena sebaran wilayah penanaman kapas dan kelompok tani binaan yang masih luas, sementara dari pihak perusahaan mitra dan pengelola masih fokus sebatas pada penyaluran input dan pembelian hasil (serat kapas). Padahal perilaku petani terhadap komoditas kapas, masih sangat dipengaruhi dengan kenyataan rendahnya produktivitas. Peningkatan produktivitas ini sendiri pada dasarnya masih berpeluang untuk ditingkatkan dengan serangkaian kegiatan yang saling terkoordinasi dan konsisten, dimulai dari penyediaan dan penyaluran input (herbisida, benih dan pupuk) tepat waktu dari perusahaan mitra, pemahaman teknis budidaya (persiapan lahan, pemeliharaan, panen) yang tepat dari pendamping lapangan serta pengawalan pasca panen dari perusahaan/pabrik pengolah serat kapas.

Rencana tindak yang mendesak untuk dilakukan kaitannya dengan perubahan perilaku petani adalah ; a) pembuatan standard operating procedure (SOP) 
pengelolaan kapas yang menjelaskan peran dan tanggungjawab masingmasing (perusahaan mitra, petani, pendamping program/disbun, dan perusahaan pengelola/ ginnery) dalam pelaksanaan program atau pengelolaan kapas, b) peningkatan intensitas penyuluhan dan pendampingan teknologi kapas diikuti dengan penyebarluasan informasi dengan pengaturan pertemuan rutin pada masing-masing kelompok tani, c) meminimalkan risiko kegagalan panen yang diakibatkan oleh kendala iklim dan organisme pengganggu tanaman (OPT) melalui kegiatan sekolah lapang di lahan-lahan petani yang pesertanya adalah petani anggota kelompok tani kapas.

d. Sebagai upaya untuk mempertahankan dan mendorong peningkatan daya saing komoditas kapas, pemberian bantuan input secara langsung (benih unggul kapas dan penyediaan saprodi tepat waktu) masih perlu diteruskan. Hal ini juga masih terkait dengan minat petani terhadap pengusahaan komoditas kapas. Pada saat yang bersamaan harga petani juga perlu ditingkatkan, dengan tetap mempertimbangkan penentuan harga impor. Penentuan harga kapas berbiji perlu mempertimbangkan harga kapas impor, dengan penyesuaian harga yang tidak terlalu jauh berbeda. Saat ini harga serat kapas yang dianggap wajar dan dapat diterima petani adalah Rp $5.000 / \mathrm{kg}$. Harga ini perlu disesuaikan agar petani dapat terpacu dalam peningkatan produksi dan harga yang lebih rendah dari harga kapas impor akan mengurangi beban perusahaan tekstil dalam pemenuhan kebutuhan serat untuk industri TPT nasional.

e. Adanya kenyataan bahwa efisiensi pada komoditas kapas tidak memiliki hubungan dengan perilaku petani terhadap risiko mendorong perlunya suatu kebijakan yang mampu meningkatkan kualitas input produksi dan pengembangan teknologi. Kualitas input, khususnya benih menjadi kunci penting dalam peningkatan produksi, untuk itu perlu adanya upaya penemuan dan perluasan varietas unggul baru yang memiliki daya adaptasi luas serta tahan terhadap serangan hama utama kapas. Kondisi ini diharapkan dapat meningkatkan minat petani dalam mengoptimalkan aktivitas pemupukan, 
karena akan berdampak langsung pada peningkatan produksi. Jika ini terjadi, maka korelasi yang diharapkan adalah perubahan perilaku petani dari risk neutral menjadi risk lover.

f. Hasil studi yang menyimpulkan tentang hubungan positif antara efisiensi dengan daya saing komoditas kapas memberi implikasi perlunya capaian efisiensi yang lebih tinggi. Salah satu faktor yang dapat diupayakan dalam mencapai kondisi tersebut adalah kemampuan meningkatkan produksi pada tingkat penggunaan sejumlah input tertentu. Efisiensi ini dapat dimulai dengan penyediaan input tepat waktu, karena input yang tersedia diawal penanaman akan memberi kesempatan yang cukup bagi petani dalam menentukan tingkat manajemen yang lebih baik, meliputi waktu tanam yang sesuai jadwal, aplikasi pemupukan tepat cara, waktu dan dosis serta pengaturan tenaga kerja yang lebih efisien. Keseluruhan tindakan ini diharapkan menjadi sumber efisiensi biaya produksi, sehingga komoditas kapas yang diusahakan dalam negeri memiliki tingkat daya saing yang lebih baik dan secara signifikan berpengaruh terhadap pemenuhan bahan baku industri tekstil dan produksi tekstil (TPT) nasional. 


\section{DAFTAR PUSTAKA}

Adegeye, A.J, and J.S. Dittoh, (1985). Essentials of Agricultural EconomicsImpact. Publishers Limited, Ibadan, Nigeria.

Aigner, D.J., C.A.K. Lovell and P. Schmidt, 1977. Formulation and Estimation of Stochastic Frontier Production Function Models. Journal of Econometrics, 6(1) : 21-37.

Akinbode S., A. Dipeolu and I. Ayinde, 2011. An Examination of Technical, Allocative and Economic Efficiencies in Ofada Rice Farming in Ogun State, Nigeria. African Journal of Agricultural Research 6(28) : 6027-6035.

Alabdullah I., E.A. Nuppenau, 2010. Assessing the Compe-titiveness of Syrian Cotton Production: A Policy Analysis Matrix Approach. "World Food System - A Contribution from Europe" Tropentag, September 14-16, 2010, Zurich

Antara, M., 2005. Perilaku Petani Dalam Pengalokasian Sumberdaya untuk Mencapai Pendapatan Maksimum di Kecamatan Sigi Biromaru Kabupaten Donggala. (Suatu Analisis Linear Programming) PS. Sosek Pertanian/ Agribisnis Jurusan Sosek Pertanian Fakultas Pertanian Universitas Tadulako - Palu. 20 halaman.

Antle, J.M., 1983. Testing the Stochastic Structure of Production: A flexible Moment Based Approach. Journal of Business and Economic Statistics 1(3):192-201.

Arsip.com, 2011. Panen Lokal Lesu, Impor Kapas 4 Bulan Pertama 2011 dari AS melesat 373,12\%.. Diakses tanggal 24 Juni 2011.

Badan Pusat Statistik, 2010. Sulawesi Selatan Dalam Angka. Makassar.

Balassa, B., 1989. Comparative Advantage, Trade Policy and Economic Development. Harvester/wheatsheat, London.

Barry, P.J., P.N. Ellinger, J.A.Hopkin, C.P. Baker, (1995). Financial Management in Agriculture. Interstate Publ. Danville, Illinois.

Battese, G.E., and G.S. Corra, (1977). Estimation of a Production Frontier Model: With Application to the Pastoral Zone of Eastern Australia. Journal Agricultural Economic, 21(3): 169-179.

Battese, G. E., and T. J. Coelli., 1988. Prediction of Firm-Level Technical Efficiencies with A Generalized Frontier Production Function and Panel Data. Journal of Econometric, 38 (1): 387-339. 
Battese, G.E., 1992. Frontier Production Function and Technical Efficiency : a Survey of Empirical Applications in Agricultural Economics. Journal Agricultural Economics, 7(1): 185-208.

Battese, G.E., and S. Hassan, 1999. Technical Efficiency of Cotton Farmers in the Vehari District of Punjab, Pakistan. Pakistan Journal of Applied Economics. 15:41-53.

Bauer, P. W., 1990. Recent Development in The Econometric Estimation of Frontier. Journal of Econometrics, 46 (1) : 39-56.

Beattie, B.R. and C.R. Taylor, 1985. The Ekonomics of Production. John Wiley and Sons, New York.

Binam, J. M, J. Tonye and N. Wandji, 2005. Source of Technical Efficiency among Smallholder Maize and Peanut Farmers in the Slash and Burn Agriculture Zone of Cameeroon. Journal of Economic Cooperation, 26(1) : 193-210

Binswanger, H.P and D.S. Sillers, (1983). Risk Aversion and Credit Constraints in Farmer's Decision. Journal Development Studi, 20: 5-21.

Boediono, 1997. Ekonomi Internasional. Yogyakarta : BPFE UGM.

Bokusheva, R. dan H. Hockmann, 2005. Production Risk and Technical Inefficiency in Russian Agriculture. Journal European Review of Agricultural Economics, 33(1) : 93-118.

Bontems, P., and A. Thomas, 2000. Information Value and Risk Premium in Agricultural Production : The Case of Split Nitrogen Aplication for Corn. American Journal Agricultural Economic, 82 (1):59-70.

Bravo-Ureta, B.E. and R. E. Evenson, 1994. Efficiency in Agricultural Production: A Case of peasant farms in Eastern Paraguay. Journal of Agricultural Economics. 10: 27-37.

Bromley, D.W., and J.P. Chavas, (1989). Risk Transactions and Economic Development in the Semiarid Tropics. Journal Economic Development Culture Change, 37(4): 719-736.

Bryant.K.J, Reeves. J.M, Nichols. R, Greene, Tingle.C.H, Studebaker.G.E, Fred M. Bourland.F.M,, Capps, Jr., and Groves.F.E., 2008. Valuing Transgenic Cotton Technologies Using a Risk/Return Framework Development. Cornel University Press, Ithaca and London

Chakraborty, K., K. Misra and P. Johnson, 2002. Cotton Farmers' Technical Efficiency: Stochastic and Nonstochastic Production Function Approaches. Agricultural and Resource Economics Review 31(2) : 211-220. 
Coelli, T.J., 1996. A Guide to Frontier Version 4.1: A Computer Program for Stochastic Frontier Production and Cost Function Estimation. Centre for Efficiency and Productivity Analysis, University of New England Armidale, New South Wales.

Coelli, T.J., D.S.P. Rao and G.E. Battese, 1998. An Introduction to Efficiency and Productivity Analysis, Kluwer-Nijhoff, Boston

De Janvry A., 1972. Optimal levels of fertilization under risk: The potential for corn and wheat fertilization under alternative price policies in Argentina. American Journal of Agricultural Economics 54 : 1-10.

Debertin, D. L., 1986. Agricultural Production Economics. Macmillan Publishing Company. United State of America.

Dillon, J.L., and P.L. Scandizzo, 1978. Risk Attitude of Subsistence Farmers in North East Brazil; A Sampling Approach. American Journal of Agricultural Economics. 60 (3) : 425-435.

Dinas Perkebunan Propinsi Sulawesi Selatan, 2001. Keragaan Pengembangan Kapas di Sulawesi Selatan Tahun 1978 - 2001. Dinas Perkebunan Sulawesi Selatan, Makasar.

Direktorat Jenderal Perkebunan, 2009. Pedoman Umum Pelaksanaan Program Peningkatan Produksi Tanaman Serat tahun 2010. Departemen Pertanian, Jakarta.

Direktorat Jenderal Perkebunan, 2001.Pedoman Penanganan Kapas Transgenik MT 2001 di Sulawesi Selatan (Tindak Lanjut SK Menteri No. 107/2001). Departemen Pertanian. Jakarta.

Direktorat Jenderal Perkebunan, 2010. Akselerasi Pengembangan Kapas. Pertemuan Koordinasi Persiapan Pelaksanaan Pengembangan Tanaman Serat Tahun 2010. Departemen Pertanian. Jakarta

Direktorat Jenderal Perkebunan, 2012. Peningkatan Produksi, Produktivitas dan Mutu Tanaman Semusim. Pedoman Teknis penanaman Tanaman Kapas Tahun 2012. Kementerian Pertanian. Jakarta

Ellis, F., 1988. Peasant Economics : Farm Household and Agricultural Development. Cambridge University Press. Cambridge.

Fariyanti, A., Kuntjoro, Hartono.S, dan A. Daryanto, 2007. Perilaku Ekonomi Rumah Tangga Petani Sayuran pada Kondisi Risiko Produksi dan harga di Kecamatan Pangalengan Kabupaten Bandung. Jurnal Agro Ekonomi, 25(2) : $178-206$

Farrell, M. J., 1957. The Measurement of Productive Efficiency. Journal of The Royal Statistical Society, Series A, 120(3) : 253-290. 
Forsund, F.R., C.A.K. Lovell and P. Schmidt., 1980. A Survey of Frontier Production Function and Their Relationship to Efficiency Measurement. Journal of Economics, 13: 5-25.

Gittinger, J.P., 1986. Analisa Ekonomi Proyek-Proyek Pertanian. Universitas Indonesia Press, Jakarta.

Greene, W. H., 1993. The Econometric Approach to Efficiency Analysis, in H. O. Fried, C. A. K. Lovell and S. S. Schmiddt (eds). The Meusurement of Produvtive Efficiency : Techniques and Applications. Oxford University Press, New York : 68-119.

Gul1, M., K. Besir, E. Dagistan, M. Akpinar and Parlakay, 2009. Determination of technical efficiency in cotton growing farms in Turkey: A case study of Cukurova region. African Journal of Agricultural Research, 4(10) : $944-949$

Hardaker, J.B, R.B.M. Huime, J.R. Anderson, (1997). Coping with Risk in Agriculture. CAB Int'l. Wallingford, UK.

Harrington, S.E., and G.R. Niehaus, (1999). Risk Management and Insurance. Irwin McGraw-Hill, Boston.

Hasnam, F.T., M.B. Nappu dan M. Syarifuddin, 1985. Penelitian Kapas di Indonesia. Jurnal Litbang Pertanian 4(4) : 87-90

Herniwati dan S. Kadir, 2009. Potensi Iklim, Sumber Daya Lahan dan Pola Tanam di Sulawesi Selatan. Prosiding Seminar Nasional Serealia. ISBN:978-979-8940-27-9

Hussain, M.S., 1999. An Analysis of the Efficiency of Cotton Farmers in the Punjab Province in Pakistan. Unpublished Ph.D. Dissertation, Graduate School of Agriculture and Resource Economics, University of New England, Armidale, Australia.

Ibrahim, 2008. Analisis Kelayakan Finansial Usahatani Kapas Transgenik. di Sulawesi Selatan. Jurnal Sains dan Teknologi, 8(2) : 126-138.

Indrayani, I.G.A.A, Sujak dan D. Soetopo, 2010. Kemampuan Pemulihan Aksesi Kapas Sebagai Respon Terhadap Kerusakan Oleh Kompleks Hama Penggerek Buah Secara Simulasi. Jurnal Littri 16(3) : 106-111

Javed M.I., S. Hassan, S.A. Adil, A. Ghafoor, K. Bakhsh and A. Siddique, 2006. Comparative Advantage of Cotton Production and its Policy Implications in Pakistan. Pakistan Journal Agricultural Scince. 43 (1) : 125-137.

Javed, M.I., N. Sahib, W. Khurshid, Lahore, I. Hassan, M.A. Raza, I.A. Baig, 2011. An analysis of productive efficiency of smallholder farms of cotton- 
wheat system in Punjab, Pakistan. Pakistan Journal Agricultural Resouces, 49(1) : 109-123.

Jondrow, J., C. A. K. Lovell, I. S. Materov, and P. Schmidt, 1982. On Estimation of Technical Efficiency in The Stochastic Frontier Production Function Models. Journal of Econometric, 19(1982) :223-238.

Just, E.R, and R.D. Pope, 1979. Production Function Estimation and Related Risk Consideration. American Journal Agricultural Economic, 6(2) : 276-284.

Kadarwati, F.T., 2006. Pemupukan Rasional dalam Upaya Peningkatan Produktivitas Kapas. Perspektif 5(2): 59-70

Kanro, M. Z dan S. Kadir, 2006. Interaksi beberapa Kultivar Kapas dengan Lima Daerah Pengembangan di Sulawesi Selatan. Jurnal Agrivigor, 5 (3): 230238

Kay, R. D., 1981, Farm Management Planning Control and Implementation: Mc. Graw Hill International Book Company.

Kibaara, B. W., 2005. Technical efficiency in Kenyan's Maize Production: An Application of the Stochastic Frontier Approach. M.Sc. Thesis. Department of Agricultural and Resource Economics, Colorado State University, Fort Collins, Colorado.

Kumbhakar, C. S., 2002. Specification and Estimation of Production Risk, Risk Preferences and Technical Efficiency. American Journal Agricultural Economic, 84(1) : 8-22.

Kumbhakar, C. S. and E.G.Tsionas, 2010. Estimation of Production Risk and Risk Preference Function: A Nonparametric approach. Ann Oper Res, 176: 369378.

Kurniawan, A.Y., S. Hartoyo, dan Syaukat, 2008 Analisis Efisiensi dan Daya Saing Usahatani Jagung Pada Lahan Kering di Kabupaten Tanah Laut Kalimantan Selatan. Jurnal Forum Pascasarjana. 31(2) : 93-103

Laha, A. and P. K. Kuri, 2011. Measurement of Allocative Efficiency ini Agriculture and its Determinants: Evidence from Rural West Bengal, India. Internasional Journal of Agricultural Research, 6(5) : 377-388

Lau, L. J., and P. A. Yotopoulos, 1971. "A Test for Relative Efficiency and Aplication to Indian Agriculture." American Journal of Agricultural Economics., 61(3) : 94-109.

Lindert, P.H. and C. P. Kindleberger, 1993. Ekonomi Internasional (Alih Bahasa Burhanuddin Abdullah) Edisi kedelapan. Penerbit Erlangga, Jakarta.

Lipsey, R.G., 1995. Pengantar Mikro Ekonomi, Jilid 1, Edisi 10, Alih Bahasa Wasana, A.J. Binarupa Aksara. Jakarta 
Liu. E., 2009. Time to Change What to Sow: Risk Preferences and Technology Adoption Decisions of Cotton Farmers in China, Department of Economics, Princeton University, Princeton.

Maesaroh, S., dan Juarini, 2010. Faktor-faktor yang Mempengaruhi Pengambilan Keputusan Petani Melakukan Diversifikasi Usahatani di Lahan Pantai Desa Garongan Kecamatan Panjatan Kabupaten Kulonprogo. Jurnal Dinamika Sosial Ekonomi (JDSE) UPN "Veteran" Yogyakarta

Meeusen, W., and J.V.D. Broeck, 1977. Efficiency Estimation from CobbDouglas Production Function with Composed Error. International Economic Review, 18(6) : 435-444.

Moscardi, E., and A. de Janvry, 1977. Attitudes Toward Risk among Peasants: An Econometric Approach. American Journal Agricultural Economic. 710-716

Mohanty S., C. Fang, and J. Chaudhary, 2003. Assessing the Competitiveness of Indian Cotton Production: A Policy Analysis Matrix Approach. The Journal of Cotton Science 7 : 65-74

Monke, E.A., and S.R. Person, 1995. The Policy Analysis Matrix for Agricultural Development. Cornel University Press. Ithaca and London.

Nasir, M., 1989. Metode penelitian. Ghalia Indonesia. Jakarta.

Nelson A.G., G.L. Casler, and O.L. Walker, 1978. Making Farm Decision in a Risky World: A guide book. South Eastern Agricultural Extension, USDA, Oregon State-Cornell- Oklahoma State Universities.

Nwaru, J.C, B. Okoye, and P.C. Ndukwu, 2011. Measurement and Determinants of Production Efficiency among Small-Holder Sweet Potato (Ipomoea Batatas) Farmers in Imo State, Nigeria]. European Journal of Scientific Research, 59(3) : 307-317.

Ogundari, K., and S.O. Ojo, 2006. An Examination of Technical, Economic and Allocative Efficiency of Small Farm : The Case Study of Cassava Farmers in Osun State of Nigeria. Journal Central European Agriculture, 7(3) : 423432.

Olarinde, L.E, V.M. Manyong and O. Akintola, 2007. Attitudes towards risk among maize farmers in the dry savanna zone of Nigeria: some prospective policies for improving food production. African Journal of Agricultural Research, 2(8) : 399-408.

Pearson S. C. Gotsch, S. Bahri, 2004. Applications of The Policy Analysis Matrix In Indonesian Agriculture. Development Alternatives Inc. - Food Policy Support Activity (DAI - FPSA) Indonesia in Collaboration with Yayasan Obor Indonesia. Jakarta 
Pearson, S. R., 1987. Net Social Profitability Domestic Resource Cost and Effective Rate of Protection, Journal of Development study.

Pindyck, R.S dan D.L., Rubinfield, 1997. Microeconomics. New Jersey : Prentice Hall.

Porter. M. E., 1993. The Competitiveness of Nations, New York; The Free Press. New York

Priyatno, D., 2009. SPSS untuk Analisis Korelasi, Regresi dan Multivariate. Penerbit Gawa Media, Yogyakarta.

Pusat Data dan Informasi Pertanian, 2009. Outlook Komoditas Pertanian (Perkebunan). Departemen Pertanian, Jakarta.

Rachman, A.H., 2007. Pengembangan Kapas Nasional. Makalah disajikan pada Pertemuan Koordinasi dan Sinkronisasi Pengembangan Kapas Nasional Tahun 2007, tanggal 11-12 Mei 2007 di Makassar.

Riajaya, P.M., M. Sholeh, F.T. Kadarwati., dan M. Rizal, 2001. Rekomendasi Waktu Tanam Kapas Di Sulawesi Selatan. Jurnal Littri, 7(2) : 35-42.

Robinson, L.J., dan P.J. Barry, 1987. The Competitive Firm's Response to Risk. Macmillan Publisher, London.

Sahid, M., 1995. Perwilayahan Komoditas Kapas di Sulawesi Selatan. Laporan Penyusunan Strategi Perwilayahan Komoditas di Sulawesi Selatan. Makassar. 24 halaman.

Saptana, Daryanto, A., Daryanto, K. H., dan Kuntjoro, 2010. Analisis Efisiensi Teknis Produksi Usahatani Cabai Merah Besar dan Perilaku Petani dalam menghadapi Risiko. Jurnal agro ekonomi, 28(2) : 153-188.

Schmidt, P., 1976. On the Statistical Estimation of Parametric Frontier Production Function. The Review of Economics and Statistics, 37(2) : 355-374.

Sinar Tani, 2008. Kapas Indonesia Dibutuhkan Tapi belum Dilirik Petani. www.sinartani-online.com. Diakses 10 Mei 2011.

Singarimbun, M., dan S. Effendi, 1989, Metode Penelitian Survei, Lembaga Penelitian Pendidikan dan Penerangan Ekonomi Sosial (LP3ES), Jakarta

Soekartawi, 1993. Agribisnis: Teori dan Aplikasinya. Ed ke-1. Raja Grafindo Perkasa. Jakarta.

Soekartawi, 1994. Teori Ekonomi Produksi dengan Pokok Bahasan Analisis Cobb-Douglas. Raja Grafindo Persada. Jakarta. 
Sudaryanto, T., dan Hadi, U. P., 2007. Analisis Dampak Pencabutan Subsidi Ekspor kapas Negara Maju Terhadap Ekonomi Kapas Indonesia. Prosiding Lokakarya Nasional Kapas dan Rami. Pusat Penelitian dan Pengembangan Perkebunan. Bogor.

Suhendar, 2007. Benih Baru Harapan Baru. www.agrina-online.com. Diakses 10 Mei 2011.

Sulistyowati dan M. Sahid, (2005). Peluang dan Dukungan Teknologi Pengembangan Komoditas Kapas Nasional. Balai Penelitian Tanaman Tembakau dan Serat, Malang. 11 halaman

Sumaryanto, 2001. Estimasi Tingkat Efisiensi Usahatani Padi Dengan Fungsi Produksi Frontir Stokastik. Jurnal Agro Ekonomi. 19(1)

Suryana, R.N, D. Rachmina, R. Oktaviani, N. Nuryartono, A. Setiyanto, dan A. Suryana, 1997. Keunggulan Komparatif, Keunggulan Kompetitif dan Dampak Kebijaksanaan Pemerintah dalam Produksi Kapas di Indonesia. Laporan Hibah Penelitian DIKTI. LPPM IPB, Bogor. 179 halaman.

Syam, A., 2004. Analisis Efisiensi Produksi Komoditas Kapas di Sulawesi Selatan. Balai Pengkajian Teknologi Pertanian Sulawesi Tenggara. Kendari. 11 halaman.

Thamrin, S., 2007. Analisis Pendapatan Petani kapas Bollgard (bt) di Kecamatan Pammana Kabupaten Wajo. Jurnal Agrisistem, 3(2) : 70-76.

Tower, E., 1991. On Shadow Prices, Effective Protection and the Domestic Resource Cost, in David Greenaway, Michael Bleaney and Ian Stewart, eds., Companion to Economic Thought. London: Routledge.

Tower, E., 1992. Domestic Resource Cost. Journal of International Economic Integration 7(1): 20-44.

Tzouvelekas, V., C.J. Pantzios and C. Fotopoulos, 2001. Economic Efficiency in Organic Farming: Evidence from Cotton Farms in Viotia, Greece. Journal of Agricultural and Applied Economics, 33(1): 35 - 48.

Widodo, S., 1989. Production Efficiency of Rice Farmers in Java-Indonesia. Gadjah Mada University Press. Yogyakarta.

Widodo, S., 2008. Campur Sari Agroekonomi. Liberty, Yogyakarta.

Widodo, S., 2012. Politik Pertanian. Liberty, Yogyakarta.

Yotopoulos, A.P. dan J. Nugent, 1976. Economics of Development: Empirical Investigation. Harper R. Row Publisher. New York. 


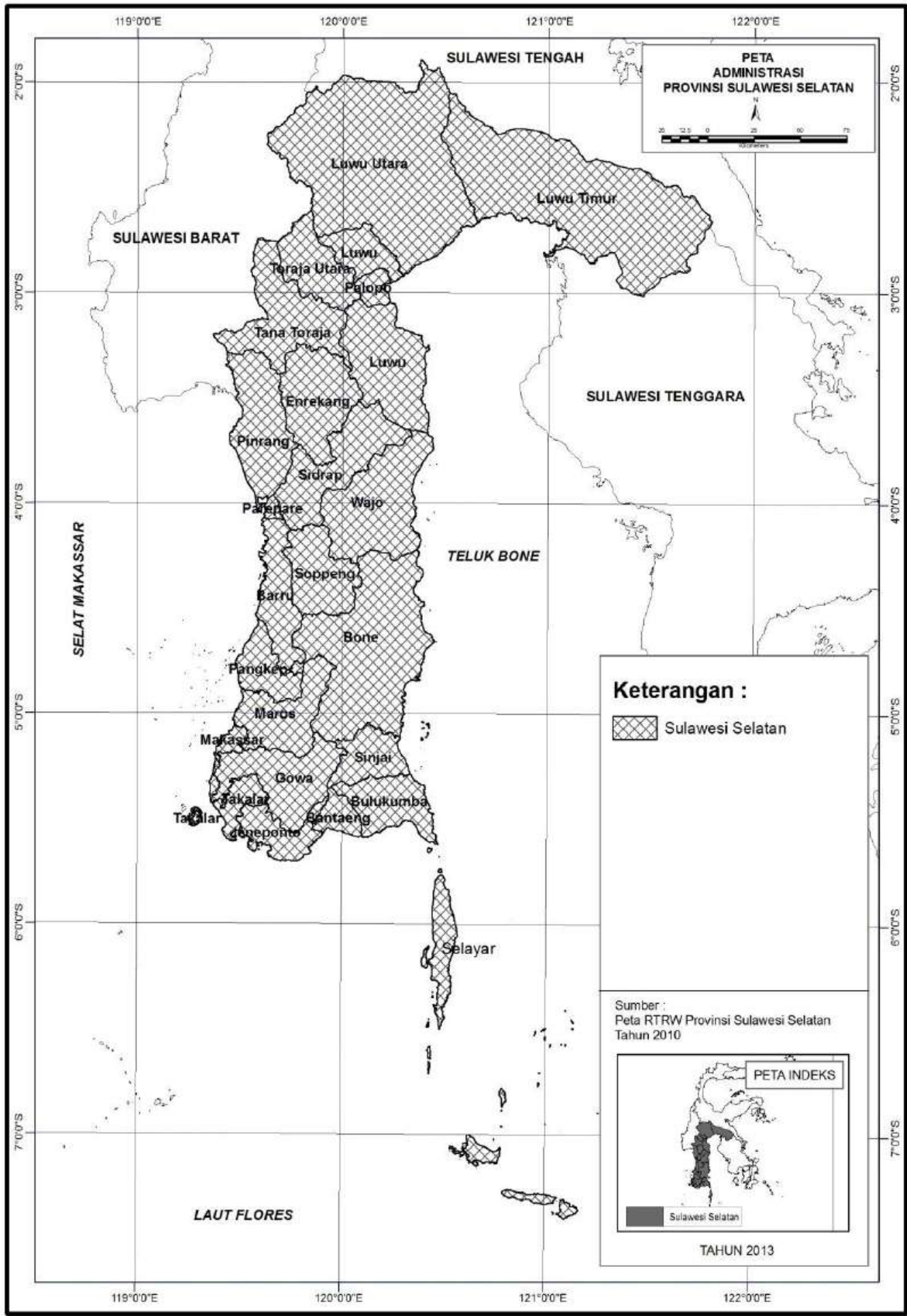

Lampiran 1. Peta Administrasi Provinsi Sulawesi Selatan 


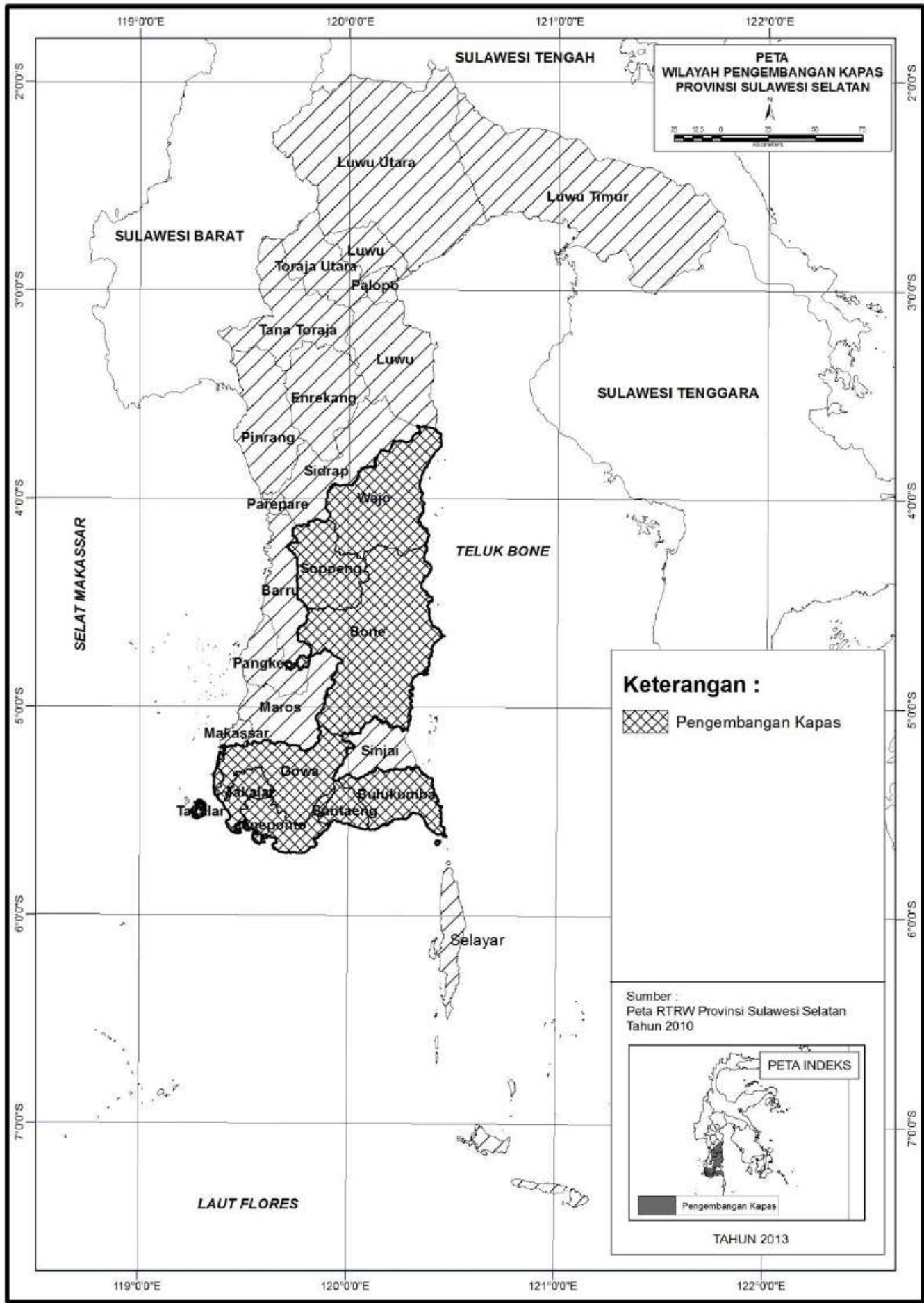

Lampiran 2. Peta Lokasi Pengembangan Kapas Rakyat di Sulawesi Selatan 


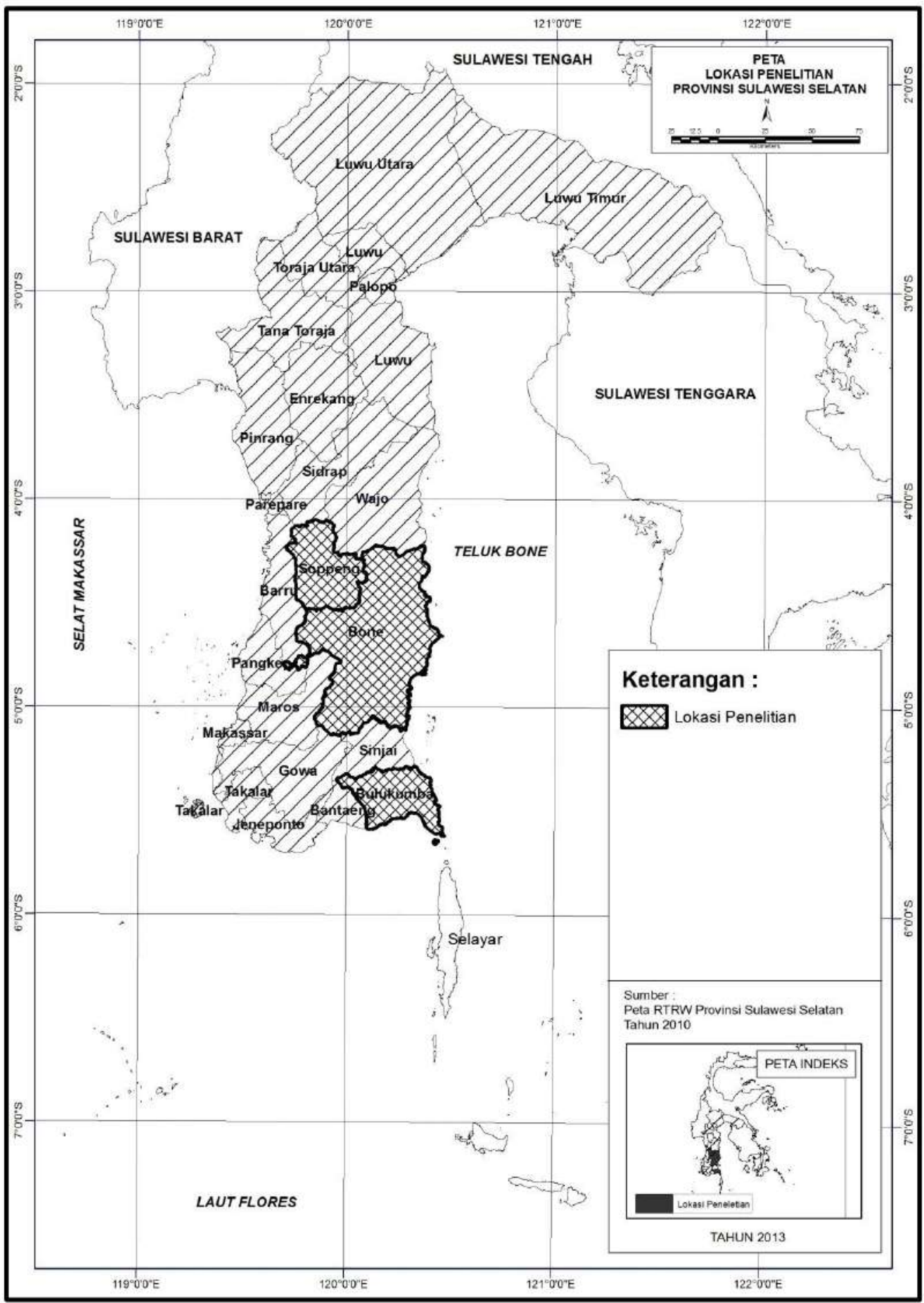

Lampiran 3. Peta Lokasi Studi 


\section{Lampiran 4. Hasil Estimasi Fungsi Produksi Usahatani Kapas Rakyat di Sulawesi Selatan.}

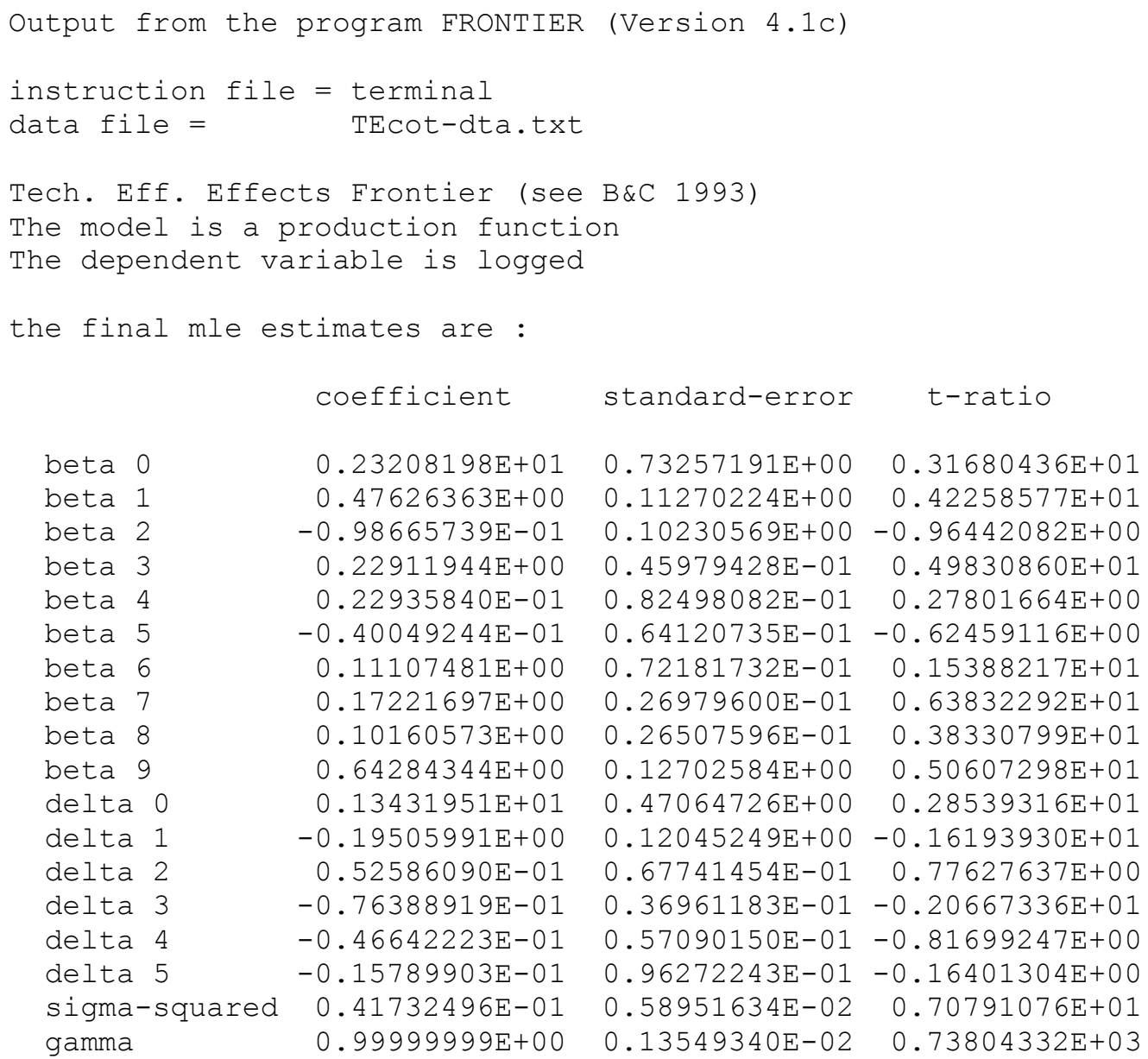

$\log$ likelihood function $=0.32812155 \mathrm{E}+02$

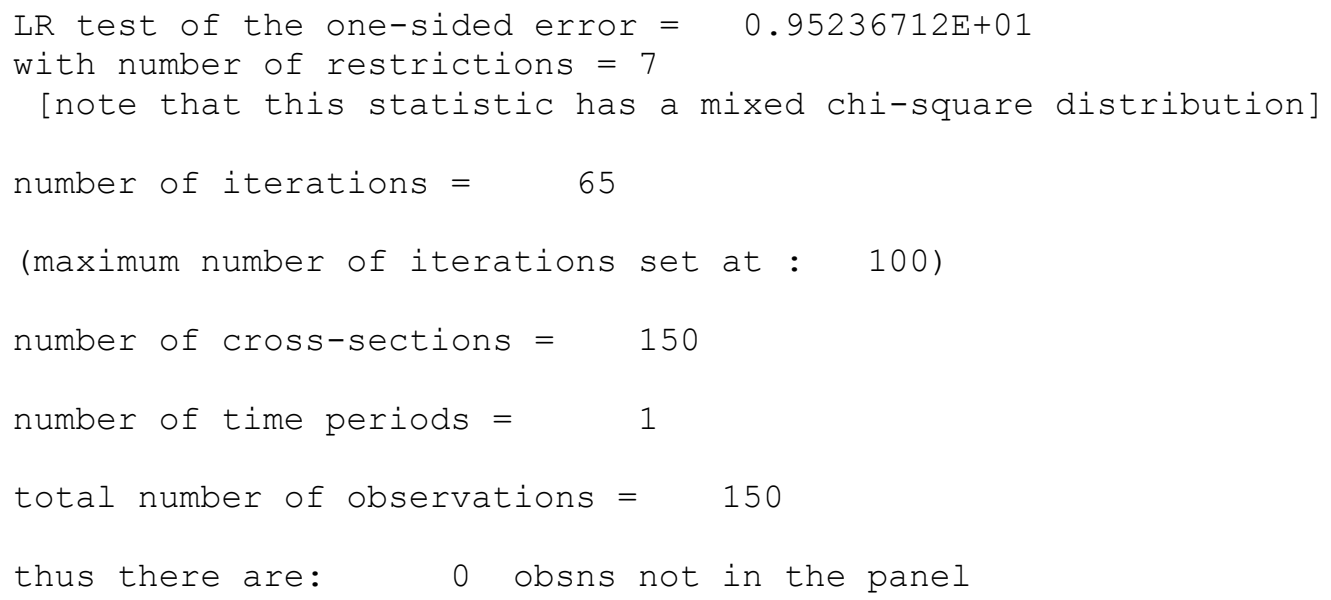




\section{Lampiran 5. Hasil Estimasi Fungsi Biaya Usahatani Kapas Rakyat di Sulawesi Selatan.}

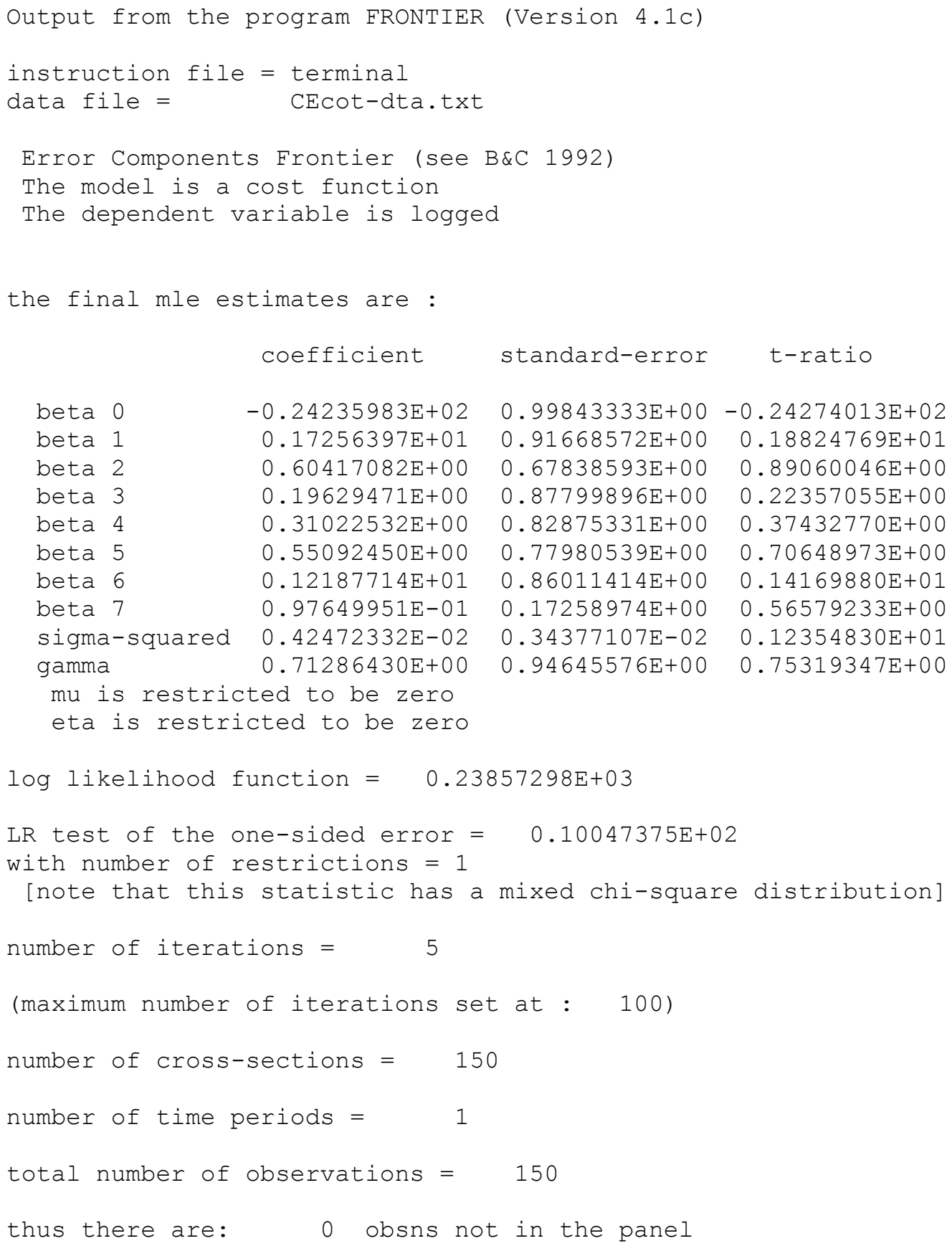


Lampiran 6. Hasil Regresi Fungsi Produksi untuk Menentukan Input Yang Paling Berpengaruh Menggunakan SPSS.

Model Summaryb

\begin{tabular}{|c|c|c|r|r|c|}
\hline Model & $\mathrm{R}$ & $\mathrm{R}$ Square & $\begin{array}{c}\text { Adjusted R } \\
\text { Square }\end{array}$ & $\begin{array}{c}\text { Std. Error of the } \\
\text { Estimate }\end{array}$ & $\begin{array}{c}\text { Durbin- } \\
\text { Watson }\end{array}$ \\
\hline 1 &, $623^{a}$ &, 388 &, 353 & 22,97848 & 1,61 \\
\hline
\end{tabular}

ANOVA $^{b}$

\begin{tabular}{|l|r|r|r|r|r|}
\hline \multicolumn{1}{|l|}{ Model } & Sum of Squares & df & Mean Square & F & Sig. \\
\hline $1 \quad$ Regression & 47138,680 & 8 & 5892,335 & 11,160 &, $000 a$ \\
Residual & 74449,460 & 141 & 528,010 & \\
Total & 121588,140 & 149 & & & \\
\hline
\end{tabular}

a. Predictors: (Constant), VARtkerja, VARurea, VARbenih, VARHerbi

VARinsek, VARNPK, VARZa,

b. Dependent Variable: VARProduksi

Coefficients $^{a}$

\begin{tabular}{|c|c|c|c|c|c|c|c|}
\hline \multirow{2}{*}{ Model } & \multicolumn{2}{|c|}{$\begin{array}{l}\text { Unstandardized } \\
\text { Coefficients }\end{array}$} & \multirow{2}{*}{$\begin{array}{c}\begin{array}{c}\text { Standardized } \\
\text { Coefficients }\end{array} \\
\text { Beta }\end{array}$} & \multirow{2}{*}{$t$} & \multirow{2}{*}{ Sig. } & \multicolumn{2}{|c|}{$\begin{array}{l}\text { Collinearity } \\
\text { Statistics }\end{array}$} \\
\hline & B & $\begin{array}{l}\text { Std. } \\
\text { Error }\end{array}$ & & & & Tolerance & VIF \\
\hline 1 (Constant) & 51,065 & 4,280 & & 11,930 &, 000 & & \\
\hline VARbenih &,- 185 &, 242 &,- 057 &,- 762 &, 447 &, 786 & 1,272 \\
\hline VARUrea &, 241 &, 052 &, 441 & 4,637 &, 000 &, 481 & 2,080 \\
\hline VARNpk &, 040 &, 092 &, 058 &, 436 &, 664 &, 242 & 4,126 \\
\hline VARZa &,- 105 &, 144 &,- 134 &,- 730 &, 467 &, 128 & 7,785 \\
\hline VARSp &, 125 &, 115 &, 163 & 1,085 &, 280 &, 191 & 5,223 \\
\hline VARInsek &, 115 &, 058 &, 195 & 1,991 &, 048 &, 454 & 2,202 \\
\hline VARherbi &, 087 &, 044 &, 148 & 1,992 &, 048 &, 787 & 1,271 \\
\hline VARtkerja &,- 114 &, 101 &,- 116 & $-1,132$ &, 259 &, 416 & 2,404 \\
\hline
\end{tabular}

a. Dependent Variable: VARProduksi 
Lampiran 7. Hasil Perhitungan Parameter Perilaku Terhadap Risiko Usahatani Kapas Rakyat di Sulawesi Selatan.

\begin{tabular}{|c|c|c|c|c|c|c|}
\hline No & $\mathbf{X i}$ & PXi.Xi & 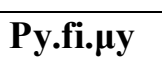 & $1 / \theta$ & $\mathbf{K}(\mathbf{s})$ & Perilaku \\
\hline 1 & 150 & 240.000 & 500,858 & 1,52 & 0,79 & Risk Neutral \\
\hline 2 & 150 & 240,000 & 500,858 & 1,52 & 0,79 & Risk Neutral \\
\hline 3 & 67 & 106,667 & 500,858 & 1,52 & 1,20 & Risk Averse \\
\hline 4 & 50 & 80,000 & 500,858 & 1,52 & 1,28 & Risk Averse \\
\hline 5 & 100 & 160,000 & 500,858 & 1,52 & 1,03 & Risk Neutral \\
\hline 6 & 100 & 160,000 & 500,858 & 1,52 & 1,03 & Risk Neutral \\
\hline 7 & 50 & 80,000 & 500,858 & 1,52 & 1,28 & Risk Averse \\
\hline 8 & 100 & 160,000 & 500,858 & 1,52 & 1,03 & Risk Neutral \\
\hline 9 & 300 & 480,000 & 500,858 & 1,52 & 0,06 & Risk Lover \\
\hline 10 & 100 & 160,000 & 500,858 & 1,52 & 1,03 & Risk Neutral \\
\hline 11 & 50 & 80,000 & 500,858 & 1,52 & 1,28 & Risk Averse \\
\hline 12 & 100 & 160,000 & 500,858 & 1,52 & 1,03 & Risk Neutral \\
\hline 13 & 100 & 160,000 & 500,858 & 1,52 & 1,03 & Risk Neutral \\
\hline 14 & 67 & 106,667 & 500,858 & 1,52 & 1,20 & Risk Averse \\
\hline 15 & 200 & 320,000 & 500,858 & 1,52 & 0,55 & Risk Neutral \\
\hline 16 & 200 & 320,000 & 500,858 & 1,52 & 0,55 & Risk Neutral \\
\hline 17 & 150 & 240,000 & 500,858 & 1,52 & 0,79 & Risk Neutral \\
\hline 18 & 100 & 160,000 & 500,858 & 1,52 & 1,03 & Risk Neutral \\
\hline 19 & 50 & 80,000 & 500,858 & 1,52 & 1,28 & Risk Averse \\
\hline 20 & 100 & 160,000 & 500,858 & 1,52 & 1,03 & Risk Neutral \\
\hline 21 & 50 & 80,000 & 500,858 & 1,52 & 1,28 & Risk Averse \\
\hline 22 & 133 & 213,333 & 500,858 & 1,52 & 0,87 & Risk Neutral \\
\hline 23 & 200 & 320,000 & 500,858 & 1,52 & 0,55 & Risk Neutral \\
\hline 24 & 100 & 160,000 & 500,858 & 1,52 & 1,03 & Risk Neutral \\
\hline 25 & 100 & 160,000 & 500,858 & 1,52 & 1,03 & Risk Neutral \\
\hline 26 & 67 & 106,667 & 500,858 & 1,52 & 1,20 & Risk Averse \\
\hline 27 & 100 & 160,000 & 500,858 & 1,52 & 1,03 & Risk Neutral \\
\hline 28 & 300 & 480,000 & 500,858 & 1,52 & 0,06 & Risk Lover \\
\hline 29 & 150 & 240,000 & 500,858 & 1,52 & 0,79 & Risk Neutral \\
\hline 30 & 200 & 320,000 & 500,858 & 1,52 & 0,55 & Risk Neutral \\
\hline 31 & 167 & 266,667 & 500,858 & 1,52 & 0,71 & Risk Neutral \\
\hline 32 & 50 & 80,000 & 500,858 & 1,52 & 1,28 & Risk Averse \\
\hline 33 & 50 & 80,000 & 500,858 & 1,52 & 1,28 & Risk Averse \\
\hline 34 & 200 & 320,000 & 500,858 & 1,52 & 0,55 & Risk Neutral \\
\hline 35 & 50 & 80,000 & 500,858 & 1,52 & 1,28 & Risk Averse \\
\hline 36 & 50 & 80,000 & 500,858 & 1,52 & 1,28 & Risk Averse \\
\hline 37 & 50 & 80,000 & 500,858 & 1,52 & 1,28 & Risk Averse \\
\hline 38 & 100 & 160,000 & 500,858 & 1,52 & 1,03 & Risk Neutral \\
\hline
\end{tabular}


Lanjutan

\begin{tabular}{|c|c|c|c|c|c|c|}
\hline No & $\mathbf{X i}$ & PXi.Xi & Py.fi. $\mu y$ & $1 / \theta$ & $\mathbf{K}(\mathbf{s})$ & Perilaku \\
\hline 39 & 100 & 160,000 & 500,858 & 1,52 & 1,03 & Risk Neutral \\
\hline 40 & 200 & 320,000 & 500,858 & 1,52 & 0,55 & Risk Neutral \\
\hline 41 & 50 & 80,000 & 500,858 & 1,52 & 1,28 & Risk Averse \\
\hline 42 & 100 & 160,000 & 500,858 & 1,52 & 1,03 & Risk Neutral \\
\hline 43 & 200 & 320,000 & 500,858 & 1,52 & 0,55 & Risk Neutral \\
\hline 44 & 50 & 80,000 & 500,858 & 1,52 & 1,28 & Risk Averse \\
\hline 45 & 50 & 80,000 & 500,858 & 1,52 & 1,28 & Risk Averse \\
\hline 46 & 100 & 160,000 & 500,858 & 1,52 & 1,03 & Risk Neutral \\
\hline 47 & 50 & 80,000 & 500,858 & 1,52 & 1,28 & Risk Averse \\
\hline 48 & 50 & 80,000 & 500,858 & 1,52 & 1,28 & Risk Averse \\
\hline 49 & 67 & 106,667 & 500,858 & 1,52 & 1,20 & Risk Averse \\
\hline 50 & 50 & 80,000 & 500,858 & 1,52 & 1,28 & Risk Averse \\
\hline 51 & 50 & 80,000 & 500,858 & 1,52 & 1,28 & Risk Averse \\
\hline 52 & 50 & 80,000 & 500,858 & 1,52 & 1,28 & Risk Averse \\
\hline 53 & 50 & 80,000 & 500,858 & 1,52 & 1,28 & Risk Averse \\
\hline 54 & 100 & 160,000 & 500,858 & 1,52 & 1,03 & Risk Neutral \\
\hline 55 & 50 & 80,000 & 500,858 & 1,52 & 1,28 & Risk Averse \\
\hline 56 & 67 & 106,667 & 500,858 & 1,52 & 1,20 & Risk Averse \\
\hline 57 & 50 & 80,000 & 500,858 & 1,52 & 1,28 & Risk Averse \\
\hline 58 & 150 & 240,000 & 500,858 & 1,52 & 0,79 & Risk Neutral \\
\hline 59 & 75 & 120,000 & 500,858 & 1,52 & 1,15 & Risk Neutral \\
\hline 60 & 75 & 120,000 & 500,858 & 1,52 & 1,15 & Risk Neutral \\
\hline 61 & 100 & 160,000 & 500,858 & 1,52 & 1,03 & Risk Neutral \\
\hline 62 & 50 & 80,000 & 500,858 & 1,52 & 1,28 & Risk Averse \\
\hline 63 & 100 & 160,000 & 500,858 & 1,52 & 1,03 & Risk Neutral \\
\hline 64 & 50 & 80,000 & 500,858 & 1,52 & 1,28 & Risk Averse \\
\hline 65 & 200 & 320,000 & 500,858 & 1,52 & 0,55 & Risk Neutral \\
\hline 66 & 50 & 80,000 & 500,858 & 1,52 & 1,28 & Risk Averse \\
\hline 67 & 100 & 160,000 & 500,858 & 1,52 & 1,03 & Risk Neutral \\
\hline 68 & 100 & 160,000 & 500,858 & 1,52 & 1,03 & Risk Neutral \\
\hline 69 & 100 & 160,000 & 500,858 & 1,52 & 1,03 & Risk Neutral \\
\hline 70 & 50 & 80,000 & 500,858 & 1,52 & 1,28 & Risk Averse \\
\hline 71 & 75 & 120,000 & 500,858 & 1,52 & 1,15 & Risk Neutral \\
\hline 72 & 100 & 160,000 & 500,858 & 1,52 & 1,03 & Risk Neutral \\
\hline 73 & 50 & 80,000 & 500,858 & 1,52 & 1,28 & Risk Averse \\
\hline 74 & 50 & 80,000 & 500,858 & 1,52 & 1,28 & Risk Averse \\
\hline 75 & 67 & 106,667 & 500,858 & 1,52 & 1,20 & Risk Averse \\
\hline 76 & 133 & 213,333 & 500,858 & 1,52 & 0,87 & Risk Neutral \\
\hline 77 & 50 & 80,000 & 500,858 & 1,52 & 1,28 & Risk Averse \\
\hline
\end{tabular}




\section{Lanjutan}

\begin{tabular}{|c|c|c|c|c|c|c|}
\hline No & $\mathbf{X i}$ & PXi.Xi & Py.fi. $\mu y$ & $1 / \theta$ & $\mathbf{K}(\mathbf{s})$ & Perilaku \\
\hline 78 & 75 & 120,000 & 500,858 & 1,52 & 1,15 & Risk Neutral \\
\hline 79 & 100 & 160,000 & 500,858 & 1,52 & 1,03 & Risk Neutral \\
\hline 80 & 50 & 80,000 & 500,858 & 1,52 & 1,28 & Risk Averse \\
\hline 81 & 167 & 266,667 & 500,858 & 1,52 & 0,71 & Risk Neutral \\
\hline 82 & 50 & 80,000 & 500,858 & 1,52 & 1,28 & Risk Averse \\
\hline 83 & 50 & 80,000 & 500,858 & 1,52 & 1,28 & Risk Averse \\
\hline 84 & 200 & 320,000 & 500,858 & 1,52 & 0,55 & Risk Neutral \\
\hline 85 & 133 & 213,333 & 500,858 & 1,52 & 0,87 & Risk Neutral \\
\hline 86 & 150 & 240,000 & 500,858 & 1,52 & 0,79 & Risk Neutral \\
\hline 87 & 140 & 224,000 & 500,858 & 1,52 & 0,84 & Risk Neutral \\
\hline 88 & 100 & 160,000 & 500,858 & 1,52 & 1,03 & Risk Neutral \\
\hline 89 & 50 & 80,000 & 500,858 & 1,52 & 1,28 & Risk Averse \\
\hline 90 & 100 & 160,000 & 500,858 & 1,52 & 1,03 & Risk Neutral \\
\hline 91 & 133 & 213,333 & 500,858 & 1,52 & 0,87 & Risk Neutral \\
\hline 92 & 200 & 320,000 & 500,858 & 1,52 & 0,55 & Risk Neutral \\
\hline 93 & 50 & 80,000 & 500,858 & 1,52 & 1,28 & Risk Averse \\
\hline 94 & 150 & 240,000 & 500,858 & 1,52 & 0,79 & Risk Neutral \\
\hline 95 & 100 & 160,000 & 500,858 & 1,52 & 1,03 & Risk Neutral \\
\hline 96 & 150 & 240,000 & 500,858 & 1,52 & 0,79 & Risk Neutral \\
\hline 97 & 133 & 213,333 & 500,858 & 1,52 & 0,87 & Risk Neutral \\
\hline 98 & 100 & 160,000 & 500,858 & 1,52 & 1,03 & Risk Neutral \\
\hline 99 & 200 & 320,000 & 500,858 & 1,52 & 0,55 & Risk Neutral \\
\hline 100 & 150 & 240,000 & 500,858 & 1,52 & 0,79 & Risk Neutral \\
\hline 101 & 50 & 80,000 & 500,858 & 1,52 & 1,28 & Risk Averse \\
\hline 102 & 100 & 160,000 & 500,858 & 1,52 & 1,03 & Risk Neutral \\
\hline 103 & 150 & 240,000 & 500,858 & 1,52 & 0,79 & Risk Neutral \\
\hline 104 & 150 & 240,000 & 500,858 & 1,52 & 0,79 & Risk Neutral \\
\hline 105 & 200 & 320,000 & 500,858 & 1,52 & 0,55 & Risk Neutral \\
\hline 106 & 67 & 106,667 & 500,858 & 1,52 & 1,20 & Risk Averse \\
\hline 107 & 300 & 480,000 & 500,858 & 1,52 & 0,06 & Risk Lover \\
\hline 108 & 150 & 240,000 & 500,858 & 1,52 & 0,79 & Risk Neutral \\
\hline 109 & 67 & 106,667 & 500,858 & 1,52 & 1,20 & Risk Averse \\
\hline 110 & 150 & 240,000 & 500,858 & 1,52 & 0,79 & Risk Neutral \\
\hline 111 & 200 & 320,000 & 500,858 & 1,52 & 0,55 & Risk Neutral \\
\hline 112 & 133 & 213,333 & 500,858 & 1,52 & 0,87 & Risk Neutral \\
\hline 113 & 300 & 480,000 & 500,858 & 1,52 & 0,06 & Risk Lover \\
\hline 114 & 150 & 240,000 & 500,858 & 1,52 & 0,79 & Risk Neutral \\
\hline 115 & 150 & 240,000 & 500,858 & 1,52 & 0,79 & Risk Neutral \\
\hline 116 & 133 & 213,333 & 500,858 & 1,52 & 0,87 & Risk Neutral \\
\hline
\end{tabular}




\section{Lanjutan}

\begin{tabular}{|c|c|c|c|c|c|c|}
\hline No & $\mathbf{X i}$ & PXi.Xi & 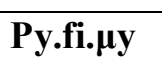 & $1 / \theta$ & $\mathbf{K}(\mathbf{s})$ & Perilaku \\
\hline 117 & 133 & 213,333 & 500,858 & 1,52 & 0,87 & Risk Neutral \\
\hline 118 & 100 & 160,000 & 500,858 & 1,52 & 1,03 & Risk Neutral \\
\hline 119 & 100 & 160,000 & 500,858 & 1,52 & 1,03 & Risk Neutral \\
\hline 120 & 50 & 80,000 & 500,858 & 1,52 & 1,28 & Risk Averse \\
\hline 121 & 250 & 400,000 & 500,858 & 1,52 & 0,31 & Risk Neutral \\
\hline 122 & 50 & 80,000 & 500,858 & 1,52 & 1,28 & Risk Averse \\
\hline 123 & 100 & 160,000 & 500,858 & 1,52 & 1,03 & Risk Neutral \\
\hline 124 & 267 & 426,667 & 500,858 & 1,52 & 0,22 & Risk Lover \\
\hline 125 & 133 & 213,333 & 500,858 & 1,52 & 0,87 & Risk Neutral \\
\hline 126 & 100 & 160,000 & 500,858 & 1,52 & 1,03 & Risk Neutral \\
\hline 127 & 100 & 160,000 & 500,858 & 1,52 & 1,03 & Risk Neutral \\
\hline 128 & 150 & 240,000 & 500,858 & 1,52 & 0,79 & Risk Neutral \\
\hline 129 & 150 & 240,000 & 500,858 & 1,52 & 0,79 & Risk Neutral \\
\hline 130 & 150 & 240,000 & 500,858 & 1,52 & 0,79 & Risk Neutral \\
\hline 131 & 133 & 213,333 & 500,858 & 1,52 & 0,87 & Risk Neutral \\
\hline 132 & 160 & 256,000 & 500,858 & 1,52 & 0,74 & Risk Neutral \\
\hline 133 & 150 & 240,000 & 500,858 & 1,52 & 0,79 & Risk Neutral \\
\hline 134 & 150 & 240,000 & 500,858 & 1,52 & 0,79 & Risk Neutral \\
\hline 135 & 100 & 160,000 & 500,858 & 1,52 & 1,03 & Risk Neutral \\
\hline 136 & 200 & 320,000 & 500,858 & 1,52 & 0,55 & Risk Neutral \\
\hline 137 & 50 & 80,000 & 500,858 & 1,52 & 1,28 & Risk Averse \\
\hline 138 & 200 & 320,000 & 500,858 & 1,52 & 0,55 & Risk Neutral \\
\hline 139 & 133 & 213,333 & 500,858 & 1,52 & 0,87 & Risk Neutral \\
\hline 140 & 150 & 240,000 & 500,858 & 1,52 & 0,79 & Risk Neutral \\
\hline 141 & 133 & 213,333 & 500,858 & 1,52 & 0,87 & Risk Neutral \\
\hline 142 & 300 & 480,000 & 500,858 & 1,52 & 0,06 & Risk Lover \\
\hline 143 & 50 & 80,000 & 500,858 & 1,52 & 1,28 & Risk Averse \\
\hline 144 & 50 & 80,000 & 500,858 & 1,52 & 1,28 & Risk Averse \\
\hline 145 & 100 & 160,000 & 500,858 & 1,52 & 1,03 & Risk Neutral \\
\hline 146 & 150 & 240,000 & 500,858 & 1,52 & 0,79 & Risk Neutral \\
\hline 147 & 50 & 80,000 & 500,858 & 1,52 & 1,28 & Risk Averse \\
\hline 148 & 75 & 120,000 & 500,858 & 1,52 & 1,15 & Risk Neutral \\
\hline 149 & 150 & 240,000 & 500,858 & 1,52 & 0,79 & Risk Neutral \\
\hline 150 & 100 & 160,000 & 500,858 & 1,52 & 1,03 & Risk Neutral \\
\hline
\end{tabular}

Keterangan :

$\theta=$ standar deviasi produksi $(\delta \mathrm{y}) /$ rata-rata hasil $(\mu \mathrm{y})=322 / 486=0,66$

Pxi $=$ harga urea $=$ Rp. 1.600

Pyi $=$ harga output $=$ Rp. 4.250

fi $=$ koefisien input urea $=0,241$

$\mathrm{K}_{(\mathrm{s})}=$ parameter perilaku risiko $\quad \mathrm{K}_{(\mathrm{s})}=\frac{1}{\theta}\left[1-\frac{\text { Pi.Xi }}{\text { Py.fi. } \mu y}\right]$ 
Lampiran 8. Perhitungan Nilai Tukar Bayangan

\begin{tabular}{llc}
\hline No & Bulan & Tahun 2011 (Rp/ US) \\
\hline 1 & Januari & $8,992,38$ \\
2 & Februari & $8,868,00$ \\
3 & Maret & $8,717,48$ \\
4 & April & $8,608,30$ \\
5 & Mei & $8,512,80$ \\
6 & Juni & $8,251,00$ \\
7 & Juli & $8,490,29$ \\
8 & Agustus & $8,489,21$ \\
9 & September & $8,712,55$ \\
10 & Oktober & $8,850,81$ \\
11 & Nopember & $8,970,14$ \\
12 & Desember & $9,043,19$ \\
\hline & rata-rata & $8,708,85$ \\
\hline
\end{tabular}

Sumber : Bank Indonesia,2011

Konversi Ekspor dan Impor Dalam Mata Uang Rupiah

\begin{tabular}{ccc}
\hline 2011 & US \$ & Rp \\
\hline Ekspor & $169,183,462,558,00$ & $1,473,392,692,967,140,00$ \\
Impor & $145,566,088,326,00$ & $1,267,712,621,792,520,00$ \\
\hline
\end{tabular}

Nilai Tukar Bayangan (SER)

Total Ekspor (Xt)

Total Impor (Mt)

Penerimaan Pajak Ekspor (Txt)

Penerimaan Pajak Impor (Tmt)

SCF

OER

SER

Exchange rate Premiun
Rp 1,473,392,692,967,140,00

Rp 1,267,712,621,792,520,00

Rp 28,270,000,000,000,00

Rp 24,680,000,000,000,00

1,001311408

$\operatorname{Rp} 8,708,85$

Rp 8,697,44

0,998690309 
Lampiran 9. Perhitungan Harga Bayangan Serat Kapas (output)

\begin{tabular}{|c|c|c|}
\hline No & Keterangan & Serat Kapas \\
\hline 1 & FOB Kapas di China $(\text { US } \$ / \text { Ton })^{1)}$ & 3,00 \\
\hline 2 & Freight and Insurance (US\$/Ton) $)^{2)}$ & 0,30 \\
\hline 3 & Harga CIF Indonesia (US\$/Ton) & 3,30 \\
\hline 4 & Nilai Tukar Bayangan (Rp/US\$) & $8,697,44$ \\
\hline 5 & Harga CIF dalam mata uang domestik (Rp/Ton) & $28,701,55$ \\
\hline 6 & Harga CIF (Rp/Kg) & $28,701,55$ \\
\hline 7 & \multicolumn{2}{|l|}{ Transportasi dan Handling Eksportir $(\mathrm{Rp} / \mathrm{Kg})^{3)}$} \\
\hline & a, Pelabuhan - Provinsi (Rp/Kg) & 80,00 \\
\hline & b, Penanganan (Bongkar Muat) (Rp/Kg) & 70,00 \\
\hline 8 & Harga Paritas Ekspor tingkat Pedagang Besar $(\mathrm{Rp} / \mathrm{Kg})$ & $28,551,55$ \\
\hline 9 & \multicolumn{2}{|l|}{ Biaya distribusi ke Tingkat Petani $(\mathrm{Rp} / \mathrm{Kg}))$} \\
\hline & a, Provinsi - Desa $(\mathrm{Rp} / \mathrm{Kg})$ & 100,00 \\
\hline 10 & Keuntungan Supplier (Rp/Kg) & 500,00 \\
\hline 11 & Harga Paritas Ekspor tingkat Petani $(\mathrm{Rp} / \mathrm{Kg})$ & $27,951,55$ \\
\hline & konversi ke $1 \mathrm{~kg}$ serat kapas $(1: 3)$ & $\operatorname{Rp} 9,317,18$ \\
\hline \multicolumn{3}{|c|}{$\begin{array}{l}\text { 1) www, alibaba,com } \\
\text { 2) } 10 \% \text { dari harga FOB untuk barang yang berasa } \\
\text { (Dirjen Pajak) } \\
\text { 3) Pedagang Pengumpul Lokal } \\
\text { 4) SK Menteri Keuangan RI Nomor 328/KMK } \\
\text { Keuangan RI Nomor 362/KMK,01/1998 }\end{array}$} \\
\hline
\end{tabular}

Keterangan :

Harga Paritas Ekspor tingkat Petani $=$

(( FOB Negara Pengekspor + Freight and Insurance) x Nilai Tukar Bayangan )) Transportasi dan Handling Eksportir - Biaya distribusi ke Tingkat Petani Keuntungan Supplier, 
Lampiran 10. Perhitungan Harga Bayangan Benih Kapas

\begin{tabular}{rlr}
\hline No & \multicolumn{1}{c}{ Keterangan } & Benih Kapas \\
\hline 1 & FOB Kapas di China (US\$/Ton) $)^{1)}$ & 23,60 \\
2 & Freight and Insurance (US\$/Ton) $)^{2)}$ & 2,36 \\
3 & Harga CIF Indonesia (US\$/Ton) & 25,96 \\
4 & Nilai Tukar Bayangan (Rp/US\$) & $8,697,44$ \\
5 & Harga CIF dalam mata uang domestik (Rp/Ton) & $225,785,54$ \\
6 & Harga CIF (Rp/Kg) & $225,785,54$ \\
7 & Transportasi dan Handling Eksportir (Rp/Kg) ${ }^{3)}$ & \\
& a, Pelabuhan - Provinsi (Rp/Kg) & 80,00 \\
& b, Penanganan (Bongkar Muat) (Rp/Kg) & 80,00 \\
8 & Harga Paritas Ekspor tingkat Pedagang Besar (Rp/kg) & $225,625,54$ \\
9 & Biaya distribusi ke Tingkat Petani (Rp/Kg)) & 125,54 \\
& Provinsi - Desa (Rp/Kg) & 500,00 \\
10 & Keuntungan Supplier (Rp/Kg) & $\mathbf{2 2 5 , 0 0 0 , 0 0}$ \\
11 & Harga Paritas Ekspor tingkat Petani $(\mathrm{Rp} / \mathrm{Kg})$ & \\
\hline
\end{tabular}

Sumber : 1) www,alibaba,com

2) $10 \%$ dari harga FOB untuk barang yang berasal dari Asia Non-Asean (Dirjen Pajak)

3) Pedagang Pengumpul Lokal

4) SK Menteri Keuangan RI Nomor 328/KMK,01/1998 dan SK Menteri Keuangan RI Nomor 362/KMK,01/1998 
Lampiran 11. Perhitungan Harga Bayangan Pupuk Urea

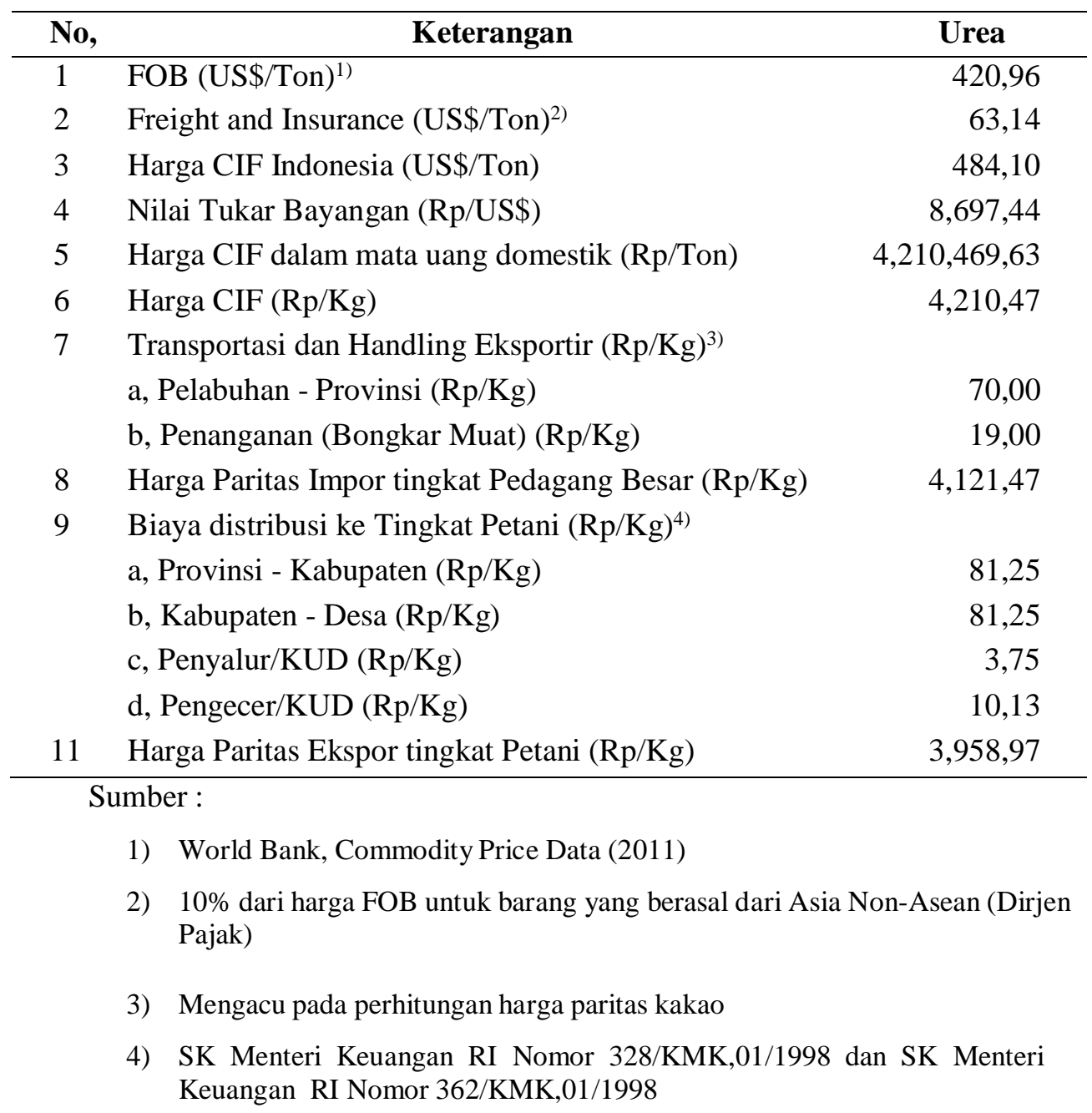

Keterangan:

harga Paritas Ekspor tingkat Petani $=$

(( FOB Negara Pengekspor + Freight and Insurance) x Nilai Tukar Bayangan )) Transportasi dan Handling Eksportir - Biaya distribusi ke Tingkat Petani 
Lampiran 12. Perhitungan Harga Bayangan Pupuk SP-36, ZA dan NPK

\begin{tabular}{clrrr}
\hline No, & Keterangan & SP 36 & \multicolumn{1}{c}{ ZA } & \multicolumn{1}{c}{ NPK } \\
\hline 1 & FOB (US\$/Ton) $)^{1)}$ & 538,26 & 180 & 350 \\
2 & Freight and Insurance (US\$/Ton) ${ }^{2)}$ & 80,74 & 18,00 & 35,00 \\
3 & Harga CIF Indonesia (US\$/Ton) & 619,00 & 198,00 & 385,00 \\
4 & Nilai Tukar Bayangan (Rp/US\$) & $8,697,44$ & $8,697,44$ & $8,697,44$ \\
5 & Harga CIF dalam mata uang domestik & $5,383,710,79$ & $1,722,093,11$ & $3,348,514,38$ \\
6 & Harga CIF (Rp/Kg) & $5,383,71$ & $1,722,09$ & $3,348,51$ \\
7 & Transportasi dan Handling Eksportir (Rp/Kg) & & & \\
& a, Pelabuhan - Provinsi (Rp/Kg) & 70,00 & 70,00 & 70,00 \\
& b, Penanganan (Bongkar Muat) (Rp/Kg) & 19,00 & 19,00 & 19,00 \\
8 & Harga Paritas Impor tingkat Pedagang Besar & $5,472,71$ & $1,811,09$ & $3,437,51$ \\
9 & Biava distribusi ke Tingkat Petani (Rp/Kg) 4$)$ & & & \\
& a, Provinsi - Kabupaten (Rp/Kg) & 65,75 & 46 & 116,4 \\
& b, Kabupaten - Desa (Rp/Kg) & 65,75 & 46 & 131,4 \\
& c, Penyalur/KUD (Rp/Kg) & 3,75 & 3,75 & 3,75 \\
& d, Pengecer/KUD (Rp/Kg) & 10,13 & 10,13 & 10,13 \\
10 & Harga Paritas Impor tingkat Petani (Rp/Kg) & $5,618,09$ & $1,916,97$ & $3,699,19$ \\
\hline
\end{tabular}

Sumber :

1) World Bank, Commodity Price Data (2011)

2) 10\% dari harga FOB untuk barang yang berasal dari Asia Non-Asean (Dirjen Pajak)

3) SK Menteri Keuangan RI Nomor 328/KMK,01/1998 dan SK Menteri Keuangan RI Nomor 362/KMK,01/1998

Keterangan:

Harga Paritas Impor tingkat Petani $=$

(( FOB Negara Pengekspor + Freight and Insurance) x Nilai Tukar Bayangan ))

+ Transportasi dan Handling Eksportir+ Biaya distribusi ke Tingkat Petani 
Lampiran 13. Input-Output, Harga dan Budget Usahatani Kapas Rakyat di Sulawesi Selatan

\begin{tabular}{|c|c|c|c|c|c|}
\hline \multirow{2}{*}{ Input dan Output } & \multirow{2}{*}{ Jumlah } & \multicolumn{2}{|c|}{ Harga (Rp/ha) } & \multicolumn{2}{|c|}{ Budget (Rp/ha) } \\
\hline & & Privat & Sosial & Privat & Sosial \\
\hline \multicolumn{6}{|l|}{ Tradable } \\
\hline 1. Benih (kg) & 6 & 224,705 & 224,705 & $1,348,232$ & $1,348,232$ \\
\hline \multicolumn{6}{|l|}{ 2, Pupuk (kg) } \\
\hline - Urea & 116 & 1,598 & 3,954 & 185,357 & 458,643 \\
\hline - SP-36 & 76 & 1,997 & 5,611 & 151,801 & 426,409 \\
\hline - NPK (Phonska) & 83 & 2,297 & 3,694 & 190,650 & 306,615 \\
\hline$-\mathrm{ZA}$ & 75 & 1,398 & 1,914 & 104,862 & 143,587 \\
\hline \multicolumn{6}{|l|}{ 3. Obat-obatan } \\
\hline - Herbisida (ltr) & 4 & 40,016 & 40,016 & 160,062 & 160,062 \\
\hline - Pestisida (gr) & 212 & 224 & 224 & 47,426 & 47,426 \\
\hline $\begin{array}{l}\text { Non Tradable } \\
\text { 1. Tenaga kerja }(\mathrm{HOK})\end{array}$ & 48 & 20,000 & 20,000 & 960,000 & 960,000 \\
\hline 2. Modal & & & & & \\
\hline - Cangkul (unit) & 2 & 69,967 & 69,967 & 139,933 & 139,933 \\
\hline - Ember (unit) & 2 & 33,467 & 33,467 & 66,933 & 66,933 \\
\hline - Sprayer (unit) & 1 & 331,667 & 331,667 & 331,667 & 331,667 \\
\hline - Keranjang (unit) & 3 & 24,833 & 24,833 & 74,500 & 74,500 \\
\hline 3. Lahan (ha) & 1 & 223,334 & 233,334 & 233,334 & 233,334 \\
\hline $\begin{array}{l}\text { Output } \\
\text { Kapas berbiji (ha) }\end{array}$ & 636 & 4,250 & 9,317 & $2,703,000$ & $5,925,726$ \\
\hline
\end{tabular}

Sumber : Data Primer, Diolah 
Lampiran 14. Hasil Perhitungan Policy Analysis Matrix Usahatani Kapas

\begin{tabular}{lrrrr}
\hline \multirow{2}{*}{ Keterangan } & \multirow{2}{*}{ Penerimaan } & \multicolumn{2}{c}{ Biaya Input } & \multirow{2}{*}{ Keuntungan } \\
\cline { 3 - 4 } & $2,703,000$ & \multicolumn{1}{c}{ Tradable } & Non Tradable & \\
\hline Harga Privat & $2,188,390$ & $1,806,367$ & $-1,291,757$ \\
Harga Sosial & $5,925,726$ & $2,890,973$ & $1,743,967$ & $1,290,787$ \\
Dampak Divergensi & $-3,222,726$ & $-702,583$ & 62,400 & $-2,582,544$ \\
\hline
\end{tabular}

Keterangan :

Indikator Dayasaing

Keunggulan Kompetitif :

Keuntungan Privat (PP)

Nilai

Rasio Biaya Privat (PCR)

Keunggulan Komparatif :

Keuntungan Sosial (SP)

Rasio Sumberdaya Domestik (DRC)

\section{Indikator Dampak Kebijakan}

Output

Transfer Output (OT)

Koefisien Proteksi Output Nominal (NPCO)

Input

Transfer Input (IT)

Transfer Faktor (TF)

Koefisien Proteksi Input Nominal (NPCI)

0,76

Input-Output

Koefisien Proteksi Efektif (EPC)

0,17

Rasio Subsidi Produsen (SRP)

Koefisien Keuntungan (PC)

Transfer Bersih (NT) 
Lampiran 15. Input-Output, Harga dan Budget Usahatani Kapas Rakyat di Sulawesi Selatan dengan Memperhitungkan Bantuan Sosial

\begin{tabular}{lrrrrr}
\hline \multirow{2}{*}{ Input dan Output } & \multirow{2}{*}{ Jumlah } & \multicolumn{2}{c}{ Harga (Rp/ha) } & \multicolumn{2}{c}{ Nilai (Rp/ha) } \\
\cline { 3 - 6 } & & Privat & Sosial & Privat & \multicolumn{1}{c}{ Sosial } \\
\hline Tradable & & & & & \\
1. Benih (kg) & 0 & 224,705 & 224,705 & & 0 \\
2. Pupuk (ha) & & & & & \\
$\quad$ - Urea & 66 & 1,598 & 3,954 & 105,462 & 260,952 \\
- SP-36 & 33 & 1,997 & 5,611 & 65,914 & 185,151 \\
- NPK (Phonska) & 25 & 2,297 & 3,694 & 57,425 & 92,354 \\
- ZA & 26 & 1,398 & 1,914 & 36,352 & 49,777
\end{tabular}

3. Obat-obatan

\begin{tabular}{lrrrrr} 
- Herbisida (ltr) & 2 & 40,016 & 40,016 & 80,031 & 80,031 \\
- Pestisida (gr) & 112 & 224 & 224 & 25,055 & 25,055 \\
\hline Non Tradable & & & & & \\
1. Tenaga kerja (HOK) & 48 & 20,000 & 18,700 & 960,000 & 897,600 \\
2. Modal & & & & & \\
- Cangkul (unit) & 2 & 69,967 & 69,967 & 139,933 & 139,933 \\
- Ember (unit) & 2 & 33,467 & 33,467 & 66,933 & 66,933 \\
- Sprayer (unit) & 1 & 331,667 & 331,667 & 331,667 & 331,667 \\
$\quad$ - Keranjang (unit) & 3 & 24,833 & 24,833 & 74,500 & 74,500 \\
3. Lahan (ha) & 1 & 223,334 & 233,334 & 233,334 & 233,334 \\
\hline Output & & & & & \\
Kapas berbiji (kg) & 636 & 4,250 & 9,317 & $2,703,000$ & $5,925,726$ \\
\hline Sumber: Data Prima
\end{tabular}

Sumber : Data Primer, Diolah 
Lampiran 16. Hasil Perhitungan Policy Analysis Matrix Usahatani Kapas Memperhitungkan Bantuan Sosial

\begin{tabular}{lrrrr}
\hline \multirow{2}{*}{ Keterangan } & \multirow{2}{*}{ Penerimaan } & \multicolumn{2}{c}{ Biaya Input } & \multirow{2}{*}{ Keuntungan } \\
\cline { 3 - 4 } & $2,703,000$ & 370,238 & $1,806,367$ & 526,395 \\
Harga Privat & $5,925,726$ & 693,320 & $1,743,967$ & $3,488,440$ \\
Harga Sosial & $-3,222,726$ & $-323,081$ & 62,400 & $-2,962,045$ \\
Dampak Divergensi & & &
\end{tabular}

Keterangan :

Indikator Dayasaing

Keunggulan Kompetitif :

Keuntungan Privat (PP)

Nilai

Rasio Biaya Privat (PCR)

526.395

0,77

Keunggulan Komparatif :

Keuntungan Sosial (SP)

3.488 .440

Rasio Sumberdaya Domestik (DRC)

0,33

Indikator Dampak Kebijakan

Output

Transfer Output (OT)

$-3.222 .726$

Koefisien Proteksi Output Nominal (NPCO)

0,46

Input

Transfer Input (IT)

Transfer Faktor (TF)

$-323.081$

62.400

Koefisien Proteksi Input Nominal (NPCI)

0,53

Input-Output

Koefisien Proteksi Efektif (EPC)

0,44

Rasio Subsidi Produsen (SRP)

$-0,50$

Koefisien Keuntungan (PC)

0,15

Transfer Bersih (NT)

$-2.962 .045$ 
Lampiran 17. Hasil Estimasi Fungsi Produksi, Perilaku dan Daya Saing Usahatani Kapas Rakyat di Sulawesi Selatan

\begin{tabular}{ccccccc}
\hline Petani & \multicolumn{2}{c}{ Efisiensi Produksi } & Perilaku & \multicolumn{2}{c}{ Daya Saing } \\
\cline { 2 - 7 } Responden & TE & EE & AE & K(s) & PCR & DRC \\
\hline 1 & 0.82 & 0.44 & 0.53 & 0.79 & 0.45 & 0.20 \\
2 & 0.86 & 0.46 & 0.53 & 0.79 & 0.45 & 0.20 \\
3 & 0.72 & 0.42 & 0.58 & 1.20 & 0.56 & 0.24 \\
4 & 0.83 & 0.46 & 0.56 & 1.28 & 0.59 & 0.26 \\
5 & 0.51 & 0.38 & 0.74 & 1.03 & 1.12 & 0.47 \\
6 & 0.77 & 0.45 & 0.59 & 1.03 & 0.55 & 0.24 \\
7 & 0.91 & 0.47 & 0.51 & 1.28 & 0.55 & 0.24 \\
8 & 0.68 & 0.29 & 0.43 & 1.03 & 1.17 & 0.49 \\
9 & 0.47 & 0.36 & 0.78 & 0.06 & 0.85 & 0.35 \\
10 & 0.52 & 0.38 & 0.72 & 1.03 & 1.11 & 0.47 \\
11 & 0.89 & 0.47 & 0.52 & 1.28 & 0.54 & 0.24 \\
12 & 0.51 & 0.38 & 0.75 & 1.03 & 1.10 & 0.46 \\
13 & 0.65 & 0.37 & 0.56 & 1.03 & 0.86 & 0.36 \\
14 & 0.84 & 0.43 & 0.51 & 1.20 & 0.64 & 0.28 \\
15 & 0.50 & 0.43 & 0.85 & 0.55 & 0.73 & 0.32 \\
16 & 0.42 & 0.29 & 0.69 & 0.55 & 3.09 & 1.15 \\
17 & 0.61 & 0.38 & 0.62 & 0.79 & 0.81 & 0.34 \\
18 & 0.80 & 0.45 & 0.56 & 1.03 & 0.48 & 0.21 \\
19 & 0.76 & 0.45 & 0.60 & 1.28 & 0.61 & 0.26 \\
20 & 0.42 & 0.30 & 0.71 & 1.03 & 2.16 & 0.84 \\
21 & 0.99 & 0.44 & 0.44 & 1.28 & 0.58 & 0.25 \\
22 & 0.50 & 0.42 & 0.86 & 0.87 & 0.86 & 0.36 \\
23 & 0.36 & 0.28 & 0.77 & 0.55 & 4.05 & 1.29 \\
24 & 0.51 & 0.28 & 0.55 & 1.03 & 1.69 & 0.65 \\
25 & 0.55 & 0.39 & 0.70 & 1.03 & 1.05 & 0.45 \\
26 & 0.62 & 0.41 & 0.67 & 1.20 & 0.77 & 0.33 \\
27 & 0.61 & 0.36 & 0.59 & 1.03 & 0.96 & 0.41 \\
28 & 0.66 & 0.28 & 0.42 & 0.06 & 1.17 & 0.48 \\
29 & 0.85 & 0.44 & 0.51 & 0.79 & 0.38 & 0.16 \\
30 & 0.70 & 0.39 & 0.55 & 0.55 & 1.11 & 0.43 \\
31 & 0.58 & 0.40 & 0.69 & 0.71 & 0.68 & 0.30 \\
32 & 0.67 & 0.36 & 0.53 & 1.28 & 0.85 & 0.37 \\
33 & 0.77 & 0.41 & 0.54 & 1.28 & 0.64 & 0.28 \\
34 & 0.86 & 0.35 & 0.40 & 0.55 & 0.54 & 0.23 \\
35 & 0.83 & 0.42 & 0.50 & 1.28 & 0.63 & 0.28 \\
36 & 0.45 & 0.39 & 0.87 & 1.28 & 1.09 & 0.48 \\
37 & 0.42 & 0.39 & 0.93 & 1.28 & 1.13 & 0.50 \\
\hline & & & & & &
\end{tabular}


Lanjutan

\begin{tabular}{ccccccc}
\hline Petani & \multicolumn{2}{c}{ Efisiensi Produksi } & Perilaku & \multicolumn{2}{c}{ Daya Saing } \\
\cline { 2 - 7 } Responden & TE & EE & AE & K(s) & PCR & DRC \\
\hline 38 & 0.57 & 0.41 & 0.71 & 1.03 & 0.66 & 0.29 \\
39 & 0.72 & 0.41 & 0.57 & 1.03 & 0.59 & 0.26 \\
40 & 0.99 & 0.39 & 0.39 & 0.55 & 0.29 & 0.13 \\
41 & 0.58 & 0.40 & 0.69 & 1.28 & 0.85 & 0.37 \\
42 & 0.57 & 0.40 & 0.69 & 1.03 & 0.74 & 0.32 \\
43 & 0.80 & 0.38 & 0.47 & 0.55 & 0.39 & 0.17 \\
44 & 0.80 & 0.42 & 0.52 & 1.28 & 0.61 & 0.27 \\
45 & 0.63 & 0.40 & 0.64 & 1.28 & 0.75 & 0.32 \\
46 & 0.45 & 0.34 & 0.75 & 1.03 & 1.33 & 0.57 \\
47 & 0.74 & 0.37 & 0.51 & 1.28 & 0.78 & 0.34 \\
48 & 0.63 & 0.36 & 0.56 & 1.28 & 0.88 & 0.37 \\
49 & 0.43 & 0.38 & 0.87 & 1.20 & 1.12 & 0.46 \\
50 & 0.75 & 0.41 & 0.54 & 1.28 & 0.61 & 0.26 \\
51 & 0.63 & 0.36 & 0.58 & 1.28 & 0.91 & 0.39 \\
52 & 0.49 & 0.42 & 0.85 & 1.28 & 0.87 & 0.38 \\
53 & 0.59 & 0.41 & 0.69 & 1.28 & 0.79 & 0.35 \\
54 & 0.56 & 0.40 & 0.71 & 1.03 & 0.71 & 0.30 \\
55 & 0.53 & 0.35 & 0.66 & 1.28 & 1.09 & 0.45 \\
56 & 0.64 & 0.44 & 0.69 & 1.20 & 0.60 & 0.26 \\
57 & 0.64 & 0.41 & 0.64 & 1.28 & 0.71 & 0.31 \\
58 & 0.96 & 0.44 & 0.46 & 0.79 & 0.35 & 0.15 \\
59 & 0.59 & 0.40 & 0.67 & 1.15 & 0.69 & 0.30 \\
60 & 0.58 & 0.40 & 0.69 & 1.15 & 0.70 & 0.31 \\
61 & 0.82 & 0.33 & 0.40 & 1.03 & 0.84 & 0.35 \\
62 & 0.59 & 0.41 & 0.68 & 1.28 & 0.72 & 0.32 \\
63 & 0.49 & 0.39 & 0.80 & 1.03 & 0.84 & 0.37 \\
64 & 0.86 & 0.37 & 0.43 & 1.28 & 0.65 & 0.28 \\
65 & 0.76 & 0.34 & 0.44 & 0.55 & 0.58 & 0.24 \\
66 & 0.72 & 0.37 & 0.51 & 1.28 & 0.81 & 0.35 \\
67 & 0.68 & 0.41 & 0.61 & 1.03 & 0.65 & 0.29 \\
68 & 0.45 & 0.33 & 0.73 & 1.03 & 1.30 & 0.51 \\
69 & 0.56 & 0.41 & 0.72 & 1.03 & 0.69 & 0.30 \\
70 & 0.41 & 0.39 & 0.93 & 1.28 & 1.16 & 0.51 \\
71 & 0.62 & 0.40 & 0.65 & 1.15 & 0.69 & 0.30 \\
72 & 0.71 & 0.30 & 0.42 & 1.03 & 0.89 & 0.36 \\
73 & 0.56 & 0.40 & 0.71 & 1.28 & 0.84 & 0.37 \\
74 & 0.67 & 0.41 & 0.62 & 1.28 & 0.74 & 0.33 \\
75 & 0.60 & 0.43 & 0.72 & 1.20 & 0.86 & 0.38 \\
\hline & & & & & &
\end{tabular}


Lanjutan

\begin{tabular}{|c|c|c|c|c|c|c|}
\hline \multirow{2}{*}{$\begin{array}{c}\text { Petani } \\
\text { Responden }\end{array}$} & \multicolumn{3}{|c|}{ Efisiensi Produksi } & \multirow{2}{*}{$\begin{array}{c}\text { Perilaku } \\
\text { K(s) }\end{array}$} & \multicolumn{2}{|c|}{ Daya Saing } \\
\hline & TE & $\mathbf{E E}$ & $\mathbf{A E}$ & & PCR & DRC \\
\hline 76 & 0.56 & 0.40 & 0.73 & 0.87 & 0.70 & 0.31 \\
\hline 77 & 0.67 & 0.36 & 0.54 & 1.28 & 0.88 & 0.37 \\
\hline 78 & 0.58 & 0.40 & 0.68 & 1.15 & 0.74 & 0.32 \\
\hline 79 & 0.66 & 0.41 & 0.62 & 1.03 & 0.67 & 0.30 \\
\hline 80 & 0.60 & 0.40 & 0.66 & 1.28 & 0.76 & 0.33 \\
\hline 81 & 0.47 & 0.39 & 0.83 & 0.71 & 1.14 & 0.47 \\
\hline 82 & 0.60 & 0.35 & 0.58 & 1.28 & 1.40 & 0.58 \\
\hline 83 & 0.62 & 0.40 & 0.65 & 1.28 & 1.02 & 0.41 \\
\hline 84 & 0.79 & 0.39 & 0.49 & 0.55 & 0.70 & 0.31 \\
\hline 85 & 0.51 & 0.38 & 0.74 & 0.87 & 0.80 & 0.34 \\
\hline 86 & 0.70 & 0.38 & 0.55 & 0.79 & 0.79 & 0.34 \\
\hline 87 & 0.54 & 0.42 & 0.78 & 0.84 & 0.83 & 0.37 \\
\hline 88 & 0.99 & 0.33 & 0.33 & 1.03 & 0.77 & 0.32 \\
\hline 89 & 0.66 & 0.38 & 0.58 & 1.28 & 1.04 & 0.41 \\
\hline 90 & 0.55 & 0.42 & 0.76 & 1.03 & 0.90 & 0.40 \\
\hline 91 & 0.59 & 0.41 & 0.70 & 0.87 & 0.89 & 0.37 \\
\hline 92 & 0.50 & 0.40 & 0.80 & 0.55 & 0.74 & 0.31 \\
\hline 93 & 0.66 & 0.39 & 0.58 & 1.28 & 0.92 & 0.37 \\
\hline 94 & 0.66 & 0.42 & 0.64 & 0.79 & 0.77 & 0.34 \\
\hline 95 & 0.77 & 0.39 & 0.51 & 1.03 & 0.77 & 0.33 \\
\hline 96 & 0.55 & 0.41 & 0.75 & 0.79 & 0.70 & 0.31 \\
\hline 97 & 0.61 & 0.41 & 0.66 & 0.87 & 0.90 & 0.39 \\
\hline 98 & 0.59 & 0.36 & 0.61 & 1.03 & 0.89 & 0.37 \\
\hline 99 & 0.52 & 0.39 & 0.74 & 0.55 & 0.83 & 0.36 \\
\hline 100 & 0.68 & 0.40 & 0.59 & 0.79 & 0.64 & 0.28 \\
\hline 101 & 0.74 & 0.43 & 0.58 & 1.28 & 0.73 & 0.32 \\
\hline 102 & 0.72 & 0.38 & 0.54 & 1.03 & 0.84 & 0.37 \\
\hline 103 & 0.45 & 0.41 & 0.92 & 0.79 & 0.84 & 0.37 \\
\hline 104 & 0.71 & 0.43 & 0.60 & 0.79 & 0.70 & 0.31 \\
\hline 105 & 0.79 & 0.37 & 0.46 & 0.55 & 0.56 & 0.23 \\
\hline 106 & 0.89 & 0.41 & 0.46 & 1.20 & 0.57 & 0.25 \\
\hline 107 & 0.60 & 0.35 & 0.58 & 0.06 & 0.84 & 0.37 \\
\hline 108 & 0.81 & 0.40 & 0.49 & 0.79 & 0.51 & 0.22 \\
\hline 109 & 0.62 & 0.39 & 0.63 & 1.20 & 0.78 & 0.34 \\
\hline 110 & 0.68 & 0.38 & 0.55 & 0.79 & 0.82 & 0.33 \\
\hline 111 & 0.80 & 0.39 & 0.48 & 0.55 & 0.66 & 0.29 \\
\hline 112 & 0.62 & 0.40 & 0.65 & 0.87 & 0.79 & 0.34 \\
\hline 113 & 0.71 & 0.31 & 0.43 & 0.06 & 0.61 & 0.26 \\
\hline 114 & 0.68 & 0.37 & 0.55 & 0.79 & 0.78 & 0.32 \\
\hline 115 & 0.80 & 0.39 & 0.49 & 0.79 & 0.69 & 0.30 \\
\hline
\end{tabular}


Lanjutan

\begin{tabular}{ccccccc}
\hline Petani & \multicolumn{2}{c}{ Efisiensi Produksi } & Perilaku & \multicolumn{2}{c}{ Daya Saing } \\
\cline { 2 - 7 } Responden & TE & EE & AE & K(s) & PCR & DRC \\
\hline 116 & 0.56 & 0.38 & 0.68 & 0.87 & 0.88 & 0.38 \\
117 & 0.64 & 0.41 & 0.64 & 0.87 & 0.76 & 0.34 \\
118 & 0.72 & 0.38 & 0.53 & 1.03 & 0.80 & 0.34 \\
119 & 0.86 & 0.31 & 0.37 & 1.03 & 0.84 & 0.34 \\
120 & 0.66 & 0.39 & 0.60 & 1.28 & 0.92 & 0.39 \\
121 & 0.58 & 0.36 & 0.61 & 0.31 & 0.69 & 0.29 \\
122 & 0.70 & 0.39 & 0.57 & 1.28 & 0.86 & 0.37 \\
123 & 0.57 & 0.41 & 0.72 & 1.03 & 0.75 & 0.32 \\
124 & 0.59 & 0.41 & 0.69 & 0.22 & 0.84 & 0.38 \\
125 & 0.58 & 0.37 & 0.64 & 0.87 & 0.92 & 0.38 \\
126 & 0.72 & 0.38 & 0.53 & 1.03 & 0.77 & 0.33 \\
127 & 0.51 & 0.40 & 0.77 & 1.03 & 0.91 & 0.39 \\
128 & 0.64 & 0.41 & 0.65 & 0.79 & 0.66 & 0.29 \\
129 & 0.51 & 0.41 & 0.80 & 0.79 & 0.86 & 0.38 \\
130 & 0.65 & 0.37 & 0.56 & 0.79 & 0.82 & 0.33 \\
131 & 0.64 & 0.39 & 0.61 & 0.87 & 0.80 & 0.35 \\
132 & 0.51 & 0.40 & 0.78 & 0.74 & 0.76 & 0.33 \\
133 & 0.53 & 0.41 & 0.78 & 0.79 & 0.75 & 0.33 \\
134 & 0.74 & 0.42 & 0.57 & 0.79 & 0.68 & 0.30 \\
135 & 0.52 & 0.40 & 0.77 & 1.03 & 0.81 & 0.35 \\
136 & 0.66 & 0.37 & 0.56 & 0.55 & 0.69 & 0.29 \\
137 & 0.79 & 0.40 & 0.51 & 1.28 & 0.75 & 0.32 \\
138 & 0.74 & 0.38 & 0.52 & 0.55 & 0.64 & 0.28 \\
139 & 0.76 & 0.38 & 0.51 & 0.87 & 0.63 & 0.27 \\
140 & 0.69 & 0.42 & 0.60 & 0.79 & 0.62 & 0.27 \\
141 & 0.64 & 0.41 & 0.63 & 0.87 & 0.85 & 0.37 \\
142 & 0.81 & 0.38 & 0.46 & 0.06 & 0.59 & 0.26 \\
143 & 0.56 & 0.42 & 0.74 & 1.28 & 0.85 & 0.37 \\
144 & 0.74 & 0.40 & 0.54 & 1.28 & 0.81 & 0.34 \\
145 & 0.86 & 0.34 & 0.40 & 1.03 & 0.82 & 0.33 \\
146 & 0.64 & 0.37 & 0.58 & 0.79 & 0.83 & 0.35 \\
147 & 0.63 & 0.38 & 0.60 & 1.28 & 0.98 & 0.39 \\
148 & 0.58 & 0.42 & 0.72 & 1.15 & 0.85 & 0.37 \\
149 & 0.53 & 0.41 & 0.77 & 0.79 & 0.83 & 0.37 \\
150 & 0.61 & 0.40 & 0.67 & 1.03 & 0.69 & 0.29 \\
\hline & & & & & &
\end{tabular}




\section{BIODATA PENULIS}

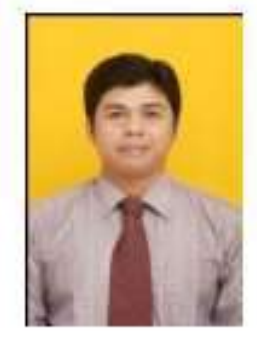

Dr. Junaedi, S.P, M.Si, lahir di Ujung Pandang, 24 Agustus 1972. Menyelesaikan pendidikan Sekolah Dasar sampai Sekolah Menengah Atas di Ujung Pandang (Makassar) pada tahun 1991. Pada tahun 1994, penulis menyelesaikan Pendidikan Diploma (D3) di Fakultas Pertanian dan Kehutanan Universitas Hasanuddin (UNHAS). Gelar Sarjana Pertanian (SP) diperoleh dari Jurusan Agronomi pada Fakultas Pertanian dan Kehutanan UNHAS pada tahun 1997 serta Magister Sains (M.Si) bidang Perencanaan dan Pengembangan Wilayah diperoleh pada tahun 2000 di Perguruan Tinggi yang sama. Pada tahun 2010 penulis melanjutkan studi S3 di Pascasarjana Fakultas Pertanian Universitas Gadjah Mada (UGM), Yogyakarta dan meraih gelar Doktor (Dr) di bidang Ekonomi Pertanian pada tahun 2013.

Mulai menggeluti dan terlibat dalam bidang penelitian sejak bergabung sebagai peneliti lepas pada Lembaga Pangabdian Pada Masyarakat (LPPM) UNHAS pada tahun 1997 sekaligus sebagai dosen tidak tetap pada Fakultas Pertanian dan Kehutanan UNHAS (1997-2000). Penulis pernah terlibat aktif pada pengembangan kapas di Sulawesi Selatan, sebagai Quality Control Assurance PT. Monagro (PT. Monsanto Indonesia, 2000-2002) serta sebagai assistant manager Perencanaan dan pengelolaan Lahan Inti pada perusahaan nasional Timsco Group (PT. Tata Harapan Cemerlang, 2004-2005).

Saat ini penulis tercatat sebagai dosen pada Jurusan Budidaya Tanaman Perkebunan, Politeknik Pertanian (POLITANI) Negeri Pangkajene dan Kepulauan (2005-sekarang). Penulis mengampu beberapa mata kuliah, diantaranya Manajemen Perkebunan, Budidaya Tanaman Perkebunan Rakyat, Kewirausahaan, Budidaya Tanaman Kopi, Penyuluhan Pertanian dan Mekanisasi Pertanian. 


\section{PENGEMBANGAN KAPAS RAKYAT' DI SULAWESI SELATAN}

Kajian Terhadap Efisiensi Produksi dan Daya Saing
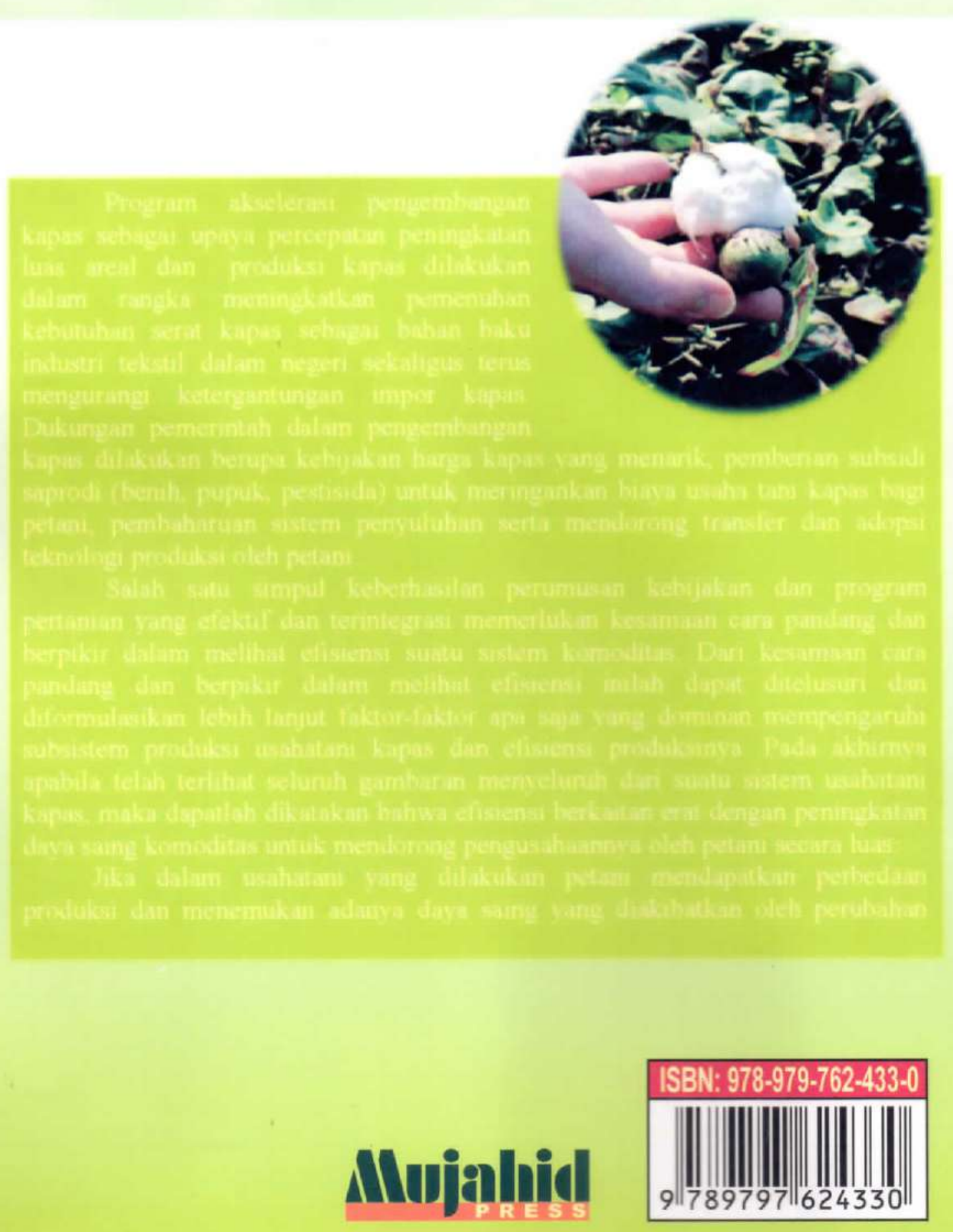